\title{
Socializing Europe - solidifying EU citizenship
}

Citation for published version (APA):

Oršolić Dalessio, T. (2013). Socializing Europe - solidifying EU citizenship. [Doctoral Thesis, Maastricht University]. Wolf Legal Publishers. https://doi.org/10.26481/dis.20130701to

Document status and date:

Published: 01/01/2013

DOI:

$10.26481 /$ dis.20130701to

Document Version:

Publisher's PDF, also known as Version of record

\section{Please check the document version of this publication:}

- A submitted manuscript is the version of the article upon submission and before peer-review. There can be important differences between the submitted version and the official published version of record.

People interested in the research are advised to contact the author for the final version of the publication, or visit the DOI to the publisher's website.

- The final author version and the galley proof are versions of the publication after peer review.

- The final published version features the final layout of the paper including the volume, issue and page numbers.

Link to publication

\footnotetext{
General rights rights.

- You may freely distribute the URL identifying the publication in the public portal. please follow below link for the End User Agreement:

www.umlib.nl/taverne-license

Take down policy

If you believe that this document breaches copyright please contact us at:

repository@maastrichtuniversity.nl

providing details and we will investigate your claim.
}

Copyright and moral rights for the publications made accessible in the public portal are retained by the authors and/or other copyright owners and it is a condition of accessing publications that users recognise and abide by the legal requirements associated with these

- Users may download and print one copy of any publication from the public portal for the purpose of private study or research.

- You may not further distribute the material or use it for any profit-making activity or commercial gain

If the publication is distributed under the terms of Article $25 \mathrm{fa}$ of the Dutch Copyright Act, indicated by the "Taverne" license above, 


\title{
Socializing Europe - Solidifying EU Citizenship
}

\author{
Tina Oršolić Dalessio
}


Production:

Wolf Legal Publishers (WLP)

PO Box 313

5060 AH Oisterwijk

The Netherlands

E-Mail:info@wolfpublishers.nl

www.wolfpublishers.com

All rights reserved. No part of this publication may be reproduced, stored in a retrieval system, or transmitted in any form or by any means, electronic, mechanical, photocopying, recording or otherwise, without prior written permission of the author. Whilst the author has tried to ensure the accuracy of this publication, the author cannot accept responsibility for any errors, omissions, misstatements, or mistakes and accept no responsibility for the use of the information presented in this work.

(C) The Author 2013 


\title{
Socializing Europe - Solidifying EU Citizenship
}

\author{
DISSERTATION \\ to obtain the degree of Doctor at \\ Maastricht University,
}

on the authority of the Rector Magnificus, Prof. dr. L.L.G. Soete, in accordance with the decision of the Board of Deans, to be defended in public on Monday, July 1, 2013, at 14.00 hours

by

Tina Oršolić Dalessio 


\section{Supervisors:}

Prof. dr. Monica Claes

Prof. dr. Luís Miguel Poiares Pessoa Maduro, European University Institute

\section{Assessment Committee:}

Prof. dr. Bruno de Witte, Chairman

Prof. dr. Tamara Ćapeta, University of Zagreb Faculty of Law

Prof. dr. Anne Pieter van der Mei 


\section{Table of Contents:}

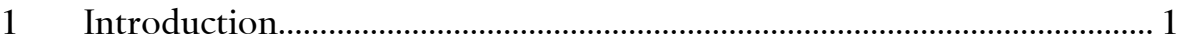

2 Chapter I - Addressing EU citizens' social rights developments at the European Union level.............................................................................. 16

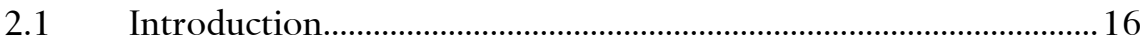

2.2 Social rights of EU citizens - Prospects and Limitations ................24

2.2.1 Establishing the general rule ........................................................... 24

2.2.2 The lawful residence requirement.................................................. 34

2.2.2.1 Defense mechanisms related to the lawful residence requirement .............................................................................. 36

2.2.2.2 Limitations of the defense mechanisms related to the lawful residence requirement.................................................... 45

2.2.3 The 'scope ratione materiae of EU law' requirement...................54

2.2.4 The equal treatment guarantee ......................................................... 61

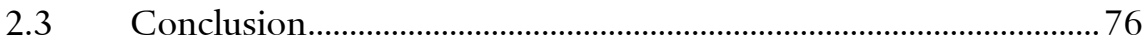

3 Chapter II - Addressing EU citizens' social rights developments at the

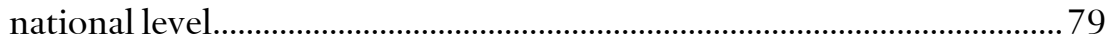

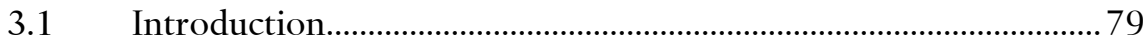

3.2 The sovereignty-related approach ………………………………..... 80

3.2.1 Examples of the sovereignty-related approach at the national

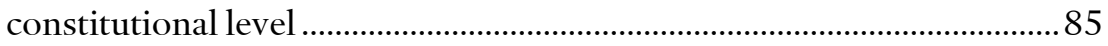

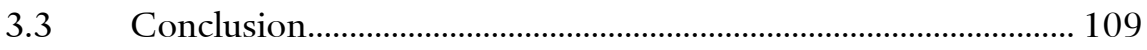

4 Chapter III - Scrutinizing the current ways of addressing EU citizens' social rights developments ...................................................................... 117

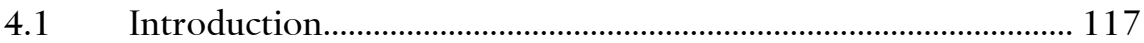

4.2 Questioning the adequacy of dominant ways of defining the social dimension of EU citizenship.

4.2.1 The adequacy of ad hoc political bargaining and a case-by-case approach driven by balancing ................................................... 120

4.2.2 The adequacy of the sovereignty-related approach................. 125

4.2.2.1 Different understandings of the notion of sovereignty

4.2.2.2 Testing the application of the sovereignty-related approach....................................................................... 139

4.3 Conclusion..................................................................................... 147 
5 Chapter IV - In search for an alternative way of constructing the social dimension of EU citizenship ..................................................................... 151

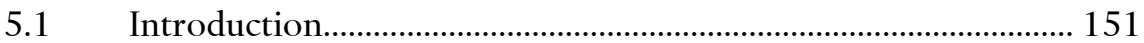

5.2 Subsidiarity as an alternative ………………………………….... 154

5.2.1 The meaning and origins of the principle of subsidiarity ....... 154

5.2.2 Applying subsidiarity in the context of social rights of EU

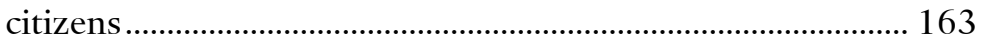

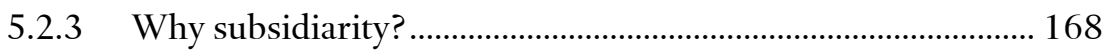

5.3 Conclusion................................................................................. 173

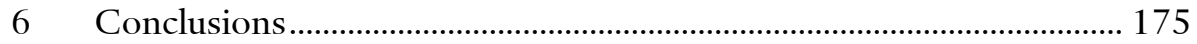

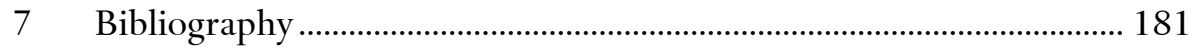

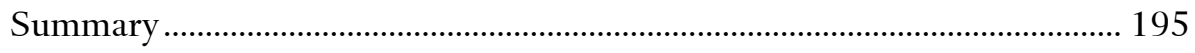

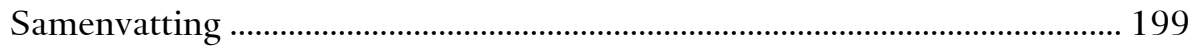

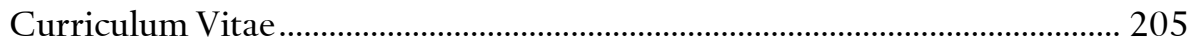




\section{Introduction}

Quo vadis Europa? This question has been asked many times throughout the history of European integration. Recently, it seems to have become more pressing then ever. The predominant reason for such a state of affairs lies in the economic crisis, which has brought to the fore many deficiencies of the current system of governance in the EU. In addition to problems tied to the financial sector, the crisis has also unveiled a number of structural problems in the EU, such as the slow institutional responsiveness to pressing realities, diverse or even conflicting interests of member countries, intransparent and often undemocratic character of decision-making process, and a general lack of perspective for deepening the project of European integration.

In that regard, it may be observed that the current crisis has moved well beyond a financial one. It gradually revealed itself as an existential one, putting in question not only the survival of the monetary union, but also the existence of the entire project of European integration. As a result, and despite the confusion as to exact causes and consequences of this crisis, one thing has become clear - maintaining the status quo is not a sustainable solution in the long run. Suggestions as to optimal means and ways of addressing the crisis, however, differ radically. Generally speaking, they can be categorized in two main groups.

On the one hand, there are those who suggest that the solution of current problems in the financial sector and beyond lies in less integration at the European level and a reinforcement of Member States' ('MS') autonomies. ${ }^{1}$

\footnotetext{
${ }^{1}$ Some of the current prominent advocates of such views are David Cameron, the British Prime Minister; Václav Klaus, the recently retired Czech president; and Nigel Farage, a member of the European Parliament and a co-chair of the Eurosceptic Europe of Freedom and Democracy group. See, for example, http://www.number10.gov.uk/news/lord-mayors-
} 
From their point of view, efforts undertaken in the past in order to make the EU more integrated, such as the introduction of the common currency, are precisely the reasons why Europe is now facing the crisis. Whereas these kinds of proposals for addressing the crisis vary significantly in their intensity, it can be concluded that their proponents all share the view that a solution of current problems lies in taking a few steps back in the European integration process and in reducing the Union's regulatory powers.

On the other hand, there are those who claim that the solution of current problems of the eurozone and, more generally, the EU, lies in more integration, 'more Europe'. ${ }^{2}$ Pro-integrative proposals also vary in their intensity. While some remain restricted to changes in the economic field, other 'stronger' versions of such proposals have somewhat paradoxically lead to calls for not only more economic and political integration, but also for a closer social union. On the whole, it can be said that the other side of the debate is lead by an increasing number of those who consider that it would be in everyone's best interest to push the European Union in a direction of further integration, far beyond the initial economic goals and the single market project.

Whichever the appropriate solution, those looking to resolve the crisis need to bear in mind that a "policy for Europe, which from the beginning pursued the goal of the free mobility of goods and services, capital and persons", must cut across different fields, including the social policy field. ${ }^{3}$ The Union's

banquet/http://www.klaus.cz/clanky/2962; http://www.klaus.cz/clanky/2930; and http://euobserver.com/political/28403.

${ }^{2}$ Some of the strongest proponents of this view are the current German Chancellor Angela Merkel, EU Commission president José Manuel Barroso and Herman Van Rompuy, the President of the European Council. See, for example, http://www.guardian.co.uk/commentisfree/2011/nov/16/cameron-vision-europemerkel; http://www.ipolitics.ca/2011/11/14/merkel-calls-for-political-union-to-solve\%E2\%80\%98europe\%E2\%80\%99s-toughest-hour\%E2\%80\%99/; http://www.bbc.co.uk/news/world-europe-18557059; http://www.consilium.europa.eu/uedocs/cms_data/docs/pressdata/en/ec/135695.pdf; http://www.neurope.eu/article/barroso-more-european-unity-our-best-answerglobalization; http://europa.eu/rapid/press-release_SPEECH-12-596_en.htm. Also see http://www.presseurop.eu/en/content/news-brief/2211991-10-countries-unitedstates-europe.

${ }^{3}$ Jürgen Habermas, 'The Postnational Constellation and the Future of Democracy' in The Postnational Constellation: Political Essays, ed. and trans. Max Pensky (The MIT Press, Cambridge 2001), p. 96. 
regulatory activity in this field is already present. This is visible, amongst other things, in the relatively recent expansion of the concept of EU citizenship, as a result of which EU law now provides certain social rights to EU citizens. ${ }^{4}$ Such development came about as a consequence of the expansive interpretation of the Treaty provisions on Union citizenship by the Court of Justice. In its case law, the CJEU interpreted the Treaty so as to provide economically inactive EU migrants with the right to equal treatment in access to social benefits under certain conditions, thereby, somewhat restricting the Member States' control over the field of social policy. ${ }^{5}$

Along with numerous other questions, the urgency to redefine the European project in view of the current crisis brings to the fore the question about the future of this social aspect of European integration. Answering this question implies deciding on what is to become of the social dimension of EU citizenship and the rights attached to it. This is a sensitive and challenging task not only because guaranteeing social rights becomes increasingly difficult in situations of economic crisis 6 , but also because tensions underlying current debates about the future of the European Union are particularly vivid and present in this field. This is not by chance. There are several reasons why this area is so strongly marked by conflicting interests and goals.

On the one hand, the social rights field is where the crucial developments of the concept of EU citizenship took place. As will be explained in more detail in the following chapter, the actual potential of this concept, which was

\footnotetext{
${ }^{4}$ See Chapter I for a more detailed analysis.

${ }^{5}$ See ibid.

${ }^{6}$ In fact, social rights are frequently the first 'to go' in these situations, as a result of attempts to address problems in the financial sector and exit the crisis. This is well exemplified by a study of recent cuts covering several European countries, by Arne Heise and Hanna Lierse, 'Budget consolidation and the European social model: the effects of European austerity programmes on social security systems', Berlin:

Friedrich-Ebert-Stiftung, Internat. Policy Analysis, 2011, available at http://library.fes.de/pdf-files/id/ipa/07891.pdf. On the negative effects of austerity on the provision of social guarantees, also see: http://www.eesc.europa.eu/?i=portal.en.press-releases.13955; http://www.efc.be/news_events/Pages/austerity-measures.aspx; http://www.cesr.org/article.php?id=1281;

http://www.coe.int/T/DGHL/Monitoring/SocialCharter/Complaints/CC78CaseDoc 5_en.pdf and http://assembly.coe.int/ASP/XRef/X2H-DW-

XSL.asp?fileid $=18916 \&$ lang $=\mathrm{EN}$.
} 
initially considered as merely symbolic in character ${ }^{7}$, became apparent mainly by virtue of its evolution in this particular field. Given the fact that the main contours of EU citizenship were defined precisely in the area of social rights, many now desire and expect as a logical consequence of this development further expansion of the European social dimension and solidarity at the EU level via the medium of Union citizenship. This is reflected in the results of the recent surveys showing that the idea of solidarity, according to EU citizens, takes precedence over all other values and that "a unified social protection system between Member States would be the main factor in reinforcing the sense of being a European citizen". 8

7 The reason for that skepticism lays in the apparently limited content the citizenship provisions inserted by the Maastricht Treaty, as well as the fact that the acquisition of EU citizenship is contingent upon possession of the nationality of a Member State, which remains in the Member States' exclusive competence. See Catherine Jacqueson, 'Union citizenship and the Court of Justice: something new under the sun? Towards social citizenship' (2002) 27 E.L. Rev. 260, p. 263. As described in more detail in Chapter I, this has lead some to conclude that Union citizenship cannot generate a sense of belonging and identity needed to create a European demos and, in turn, help the EU overcome its lack of legitimacy. See Joseph H.H. Weiler, 'To be a European Citizen', in Scritti in onore di Giuseppe Federico Mancini, Vol. II - Diritto dell'Unione Europea (Giuffrè, Milano 1998), p. 1080. Also see, Jurgen Habermas, 'Citizenship and National Identity: Some Reflections on the Future of Europe’ (1992) 12(1) Praxis International 1, p. 9.

${ }^{8}$ See the European Parliament Eurobarometer (EB Standard 70) - Autumn 2008 analysis, European Elections 2009, available at ec.europa.eu/public_opinion/archives/ebs/ebs_303_synt_en.pdf. Also see the Standard Eurobarometer 77 - Spring 2012 analysis, European Citizenship Report, available at http://ec.europa.eu/public_opinion/archives/eb/eb77/eb77_citizen_en.pdf; and the European Parliament Eurobarometer (EB/EP 77.4) from 20 August 2012, titled 'Two years to go to the 2014 European elections', available at http://www.europarl.europa.eu/aboutparliament/en/00191b53ff/Eurobarometer.ht $\mathrm{ml}$ ?tab=2012_4. The later survey also confirms that that tackling poverty and social exclusion is considered to be the first among the priority policies that Europeans want to see promoted by the European Parliament. Also see European Parliament Eurobarometer (EB/PE 76.3), Parlemeter - November 2011, available at http://www.europarl.europa.eu/pdf/eurobarometre/2012/76_3/eb76_3_synthese_an alytique_en.pdf. Other indicative surveys, in this regard, are those on EU citizens' perception of the Europe 2020 strategy, which show that social measures continue to lead the ranking of initiatives which are perceived as the most important. See the Standard Eurobarometer 75 - Spring 2011 analysis, Europe 2020 Report, available at ec.europa.eu/public_opinion/archives/eb/eb75/eb75_eu20_en.pdf and the Standard 
On the other hand, the development of the MS' social systems can be understood as one of the fundamental aspects of nation building and a "part of a general process of State building"9. This suggests that this area of policymaking is far from being politically and historically neutral. ${ }^{10}$ In that regard, it may be observed that differences between welfare systems in different MS are a direct consequence of divergent economic, historical and political circumstances in which they have developed.11 For this reason, it is understandable that the preservation of control over the area of social policy is of essential significance for MS.

An additional factor creating and perpetuating tensions in the social policy field lies in the fact that "the provision of welfare services by the Member States touches in various ways on the core European economic aim to establish and maintain an internal market"12. In that regard, choices made in social fields, previously reserved exclusively for the MS, are extremely sensitive as they require careful balancing between the two important, but conflicting goals - that of realizing the free movement of persons within the Union and promoting social solidarity as its corollary, and that of safeguarding the MS' social security systems and, more generally, public purses. ${ }^{13}$

Eurobarometer 76 - Autumn 2011 analysis, Europe 2020 Report, available at http://ec.europa.eu/public_opinion/archives/eb/eb76/eb76_en.htm. All of this seems to affirm the continuing desire of $\mathrm{EU}$ citizens to witness the expansion of solidarity and social rights at the EU level.

${ }^{9}$ Kay Hailbronner, 'Union Citizenship and Access to Social Benefits' (2005) 42 CML Rev. 1245, p. 1265. See further John Loughlin, 'The 'Hybrid' State: Reconfiguring Territorial Governance in Western'

Europe' (2009) 10 Perspectives on European Politics and Society 51; and Maurizio Ferrera, 'European Integration and National Social Citizenship: Changing Boundaries, New Structuring?' (2003) 36(6) Comparative Political Studies 611. ${ }^{10}$ Síofra O'Leary, The Evolving Concept of Community Citizenship: From the Free Movement of Persons to Union Citizenship (Kluwer, The Hague 1996), p. 143.

${ }^{11}$ Ibid. Also see Maurizio Ferrera, 'European Integration and National Social Citizenship: Changing Boundaries, New Structuring?' (2003) 36(6) Comparative Political Studies 611.

${ }^{12}$ Dragana Damjanovic and Bruno de Witte, 'Welfare Integration through EU Law: The Overall Picture in the Light of the Lisbon Treaty', EUI Working Paper LAW No. 2008/34, p. 3.

${ }^{13}$ See Koen Lenaerts and Tinne Heremans, 'Contours of a European Social Union in the Case-Law of the European Court of Justice' (2006) 2 EuConst 101, p. 101; Koen 
Lenaerts, 'European Union Citizenship, National Welfare Systems and Social Solidarity' (2011) 18(2) Jurisprudence 397, p. 401; and Anne Pieter van der Mei, Free Movement of Persons within the European Community: Cross-Border Access to Public Benefits (Hart Publishing, Oxford 2003), pp. 1, 2. This will be explained and analyzed in more detail in Chapter I. 
The financial aspect related to the area of social policy is what makes this balancing process particularly difficult. The provision of welfare services requires some sort of public funding, which in the EU still remains primarily within the responsibility of the EU member states. ${ }^{14}$ As decisions taken in the social rights field usually have direct budgetary implications and can consequently affect the financing of the MS' social security schemes, this area engages a compelling MS' interest. ${ }^{15}$ In addition to the budgetary concerns, the MS' interest in this area also arises from the fact that limiting their autonomy in the social policy field would necessarily limit other choices that can be made at the national level - including those on the appropriate model of social justice, redistributive mechanisms and policies, and the boundaries of solidarity, identity and belonging. These are some of the reasons why a prospect of decrease of national regulatory powers in this field would be regarded with contempt on part of the MS. ${ }^{16}$ Moreover, this is why it can be expected that in future discussions concerning EU citizens' social rights, the MS will likely take a firm position insisting that they remain the sole (or at least dominant) regulators of welfare issues within the European Union.

In legal terms, this position increasingly translates in the identification of state

\footnotetext{
${ }^{14}$ Dragana Damjanovic and Bruno de Witte, 'Welfare Integration through EU Law: The Overall Picture in the Light of the Lisbon Treaty', EUI Working Paper LAW No. 2008/34, p. 3.

${ }^{15}$ See further Anne Pieter van der Mei, Free Movement of Persons within the European Community: Cross-Border Access to Public Benefits (Hart Publishing, Oxford 2003), p.
} 120.

${ }^{16}$ Another related reason concerns the idea shared by some that a sense of belonging and solidarity needed to build welfare systems can exist only within national political communities. As Habermas explains, this belief is usually grounded in "the premise that the willingness of citizens to expose themselves to the risks of a redistributive social state cannot be fully explained without this ascriptive form of solidarity, the sense of being "one of us." On this reading, only a sense of national belonging understood as membership in a pre-political community of fate can exert the kind of binding effect, and can produce the sort of solidarity, that explain why self-interested citizens would place the demands of a "duty-imposing" state authority ahead of their own preferences." Jürgen Habermas, "The Postnational Constellation and the Future of Democracy' in The Postnational Constellation: Political Essays, ed. and trans. Max Pensky (The MIT Press, Cambridge 2001), pp. 100-1. Also see Alessandra Bosco 'Are national social protection systems under threat? Observations on the recent case law of the Court of Justice', (2000) 7 Notre Europe, European issues 1, p. 3. 
competences in the social policy field as inalienable. ${ }^{17}$ Recent national constitutional decisions ruling on the compatibility of primary EU law with national constitutional orders provide the best proof of that. In these judgments, national highest tribunals have made it clear that the area of social policy engages a strong national interest and represents one of what they consider essential state tasks. ${ }^{18}$ Accordingly, this area should remain within the primary state control and any attempts to regulate social issues at the Union level will be subject to high levels of scrutiny.

While the Treaty on European Union in Article 4(2) explicitly affirms respect for national identities and essential state functions ${ }^{19}$, it is not entirely clear what exactly falls under these functions and what the declared respect for them implies. True, EU law recognizes MS' powers in the area of social policy. ${ }^{20}$ Still, regulating the area of social policy falls under a shared competence $^{21}$, which has already been extensively used by the EU. The Union's regulatory activity in this area is visible in, amongst other things, EU

\footnotetext{
17 See Chapter II for a more detailed analysis. Also see Andreas J. Obermaier, 'Finetuning the Jurisprudence: The ECJ's Judicial Activism and Self-restraint' Institute for European Integration Research Working Paper No. 02/2008, pp. 4, 33.

18 See the German and the Polish Lisbon Treaty case. The English translation of the case BVerfG, 2 BvE 2/08 vom 30.6.2009, Absatz-Nr. (1 - 421) (German Lisbon Treaty case) is available at http://www.bundesverfassungsgericht.de/entscheidungen/es20090630_2bve000208 en.html. The English translation of the Polish Constitutional Tribunal's judgment $K$ 32/09 of 24 November 2010 (Polish Lisbon Treaty case), available at http://www.trybunal.gov.pl/eng/summaries/wstep_gb.htm.

${ }^{19}$ See Article 4 of the Treaty on European Union ('TEU'), Consolidated versions of the Treaty on European Union and the Treaty on the Functioning of the European Union, Official Journal C 115 of 9 May 2008.

${ }^{20}$ In particular, the CJEU has clarified that EU law "does not detract from the power of the Member States to organise their social security systems, and that, in the absence of harmonisation at Community level, it is for the legislation of each Member State to determine the conditions in which social security benefits are granted". However, when exercising that power, the Member States must comply with EU law and sometimes make adjustments to their national systems of social security. According to the Court, this does not undermine their sovereign powers in this field. Case C372/04 Watts [2006] ECR I-04325, paras 92, 121, 146, 147. Also see case C-75/11 Commission v Austria [2012] ECR 00000, para 47.

${ }^{21}$ See Article 4, Part I of the Treaty on the Functioning of the European Union ('TFEU'), Consolidated versions of the Treaty on European Union and the Treaty on the Functioning of the European Union, Official Journal C 115 of 9 May 2008.
} 
legislation and case law of the European Court of Justice ('CJEU') dealing with access to social benefits of EU citizens. This line of case law and legislation has indisputably limited the MS' regulatory autonomy and put in question their previously exclusive power of control over the area of social policy. ${ }^{22}$

On the whole, it can be concluded that both national and supranational legal discourse, as well as political debates witness that the area of social policy is characterized by serious tensions and opposing interests. On the one hand, there is an interest in preserving the MS' regulatory autonomy, public purses and social security systems. On the other hand, there is an interest in promoting the freedom of movement in the internal market, strengthening the protection of social rights of Union citizens' and expanding solidarity at the EU level. The fundamental nature of these interests is what efficiently generates and perpetuates the strong push-pull relationship present in the area of social policy. It is, thus, not surprising to find so radically divergent views on the best ways to approach and define the future of the European social dimension. Moreover, it is not surprising to witness a lack of an elaborated political and legal agenda for development of citizens' social rights at the European level. ${ }^{23}$

Yet, in order to responsibly and constructively tackle the issue of evolvement of the concept of EU citizenship in the social rights field, it does not suffice to identify tensions underlying the mentioned debates. Engagement in an informed and fruitful discussion about the future of the social aspect of EU citizenship implies careful examination of different ways in which the identified tensions have so far played out in both national and supranational discourse. Thus, in order to tackle the prospect of development of social rights of Union citizens, it is crucial to analyze methods that have so far been used by both the national and the EU actors in their attempts to address issues and conflicts inherent to the area of social policy.

This kind of analysis is needed not only in order to provide clarity as to exact implications of the ongoing discourse on this topic, but also in order to identify advantages and disadvantages of the currently assumed approaches at

\footnotetext{
22 See Chapter I for a detailed description of revelant case law and legislation. ${ }^{23}$ See further Miguel Poiares Maduro, 'Europe's Social Self: The Sickness Unto Death' in Jo Shaw (ed), Social Law and Policy in an Evolving European Union (Hart Publishing, Oxford 2000).
} 
both levels of decision-making, national and European. Such a structured and in-depth analysis of dynamics and trends in developing the social dimension of EU citizenship should, in turn, lead us to valuable conclusions as to adequate and desirable ways of addressing this important and sensitive aspect of the European integration process in the future.

Since the focus of this research is legal, rather than political, the analysis will cover mainly legal acts and actors, with an emphasis on highest judicial instances at both levels of governance. In order to evaluate current ways of addressing the development of European citizens' social rights, the following chapters will thus describe and subsequently criticize relevant legislation and case law at the Union and the MS level respectively. It will be shown that neither national, nor European actors have been so far able to answer the question about the prospect of development of the European social model in a comprehensive way. The overall conclusion will, thus, be that there is a lack of an elaborated agenda for development of citizens' social rights in the EU.24 However, while no clear plan or criteria were so far put in place in order to guide the evolvement of this important aspect of EU citizenship, certain tendencies in approaching this issue are detectible at both the national and the supranational level.

As far as the EU level is concerned, these tendencies are best visible in the CJEU's case law dealing with the interpretation of primary and secondary EU legislation concerning rights of EU citizens. Through this case law, the concept of EU citizenship has been gradually expanded so as to guarantee protection of certain social rights to European citizens. By a generous interpretation of the Treaty provisions on Union citizenship, the Court of Justice has come up with a rule that provides the right to equal treatment in access to social benefits to all economically inactive Union migrants lawfully residing in a territory of another MS, provided that their situation falls within the scope ratione materiae of EU law. ${ }^{25}$

\footnotetext{
${ }^{24}$ Such lack of a comprehensive agenda in this field implies that there exists no agreement on the core set of European social values, no clear rationale commanding social developments of the concept of EU citizenship, no criterion of distributive justice at the EU level and, generally, no idea of what the European social identity should consist of. See footnote 23 above. A lack of such an agenda consequently makes it unclear whether the EU is determined to go beyond protecting social rights purely as a mechanism for preventing unfair competition and enabling market integration and, if so, to which extent.

${ }^{25}$ Case C-85/96 Martínez Sala [1998] ECR I-2691.
} 
The consequences of this line of case law and the subsequently adopted legislation will be examined in Chapter I in order to identify the approach predominantly assumed by EU legislative and judicial actors in dealing with the social aspect of Union citizenship. An emphasis will be put on implications of this expansion of the concept of EU citizenship on promoting the freedom of movement, as well as on expanding solidarity and social rights in the EU. In addition, in order to better depict ways in which relevant acts and actors have dealt with the identified tensions underlying the area of social policy, an emphasis will be put on consequences of this development on the MS' regulatory autonomy. A study will therefore be made of conditions and limitations in access to social rights of non-economic migrant EU citizens, and mechanisms left at the MS' disposal for protecting their vital financial and welfare interests.

It will be explained that EU law did not leave the MS completely powerless in defending their social security systems and public purses. On the contrary, it provided the MS with a number of 'defense mechanisms', which they can use in order to safeguard their financial interests and protect themselves from 'welfare tourism'26. These mechanisms function as economic safeguards, protecting the MS' public finances from unreasonable burdens from abroad. Yet, as will be described in more detail in the following chapter, EU law also prescribes certain limitations in the application of these 'defense mechanisms'. In particular, it requires from the MS to comply with the general principles of EU law (mainly, the principle of proportionality) whenever they use the 'defense mechanisms' left at their disposal.

A careful observation of the give-and-take approach assumed at the Union level in the social policy area will help the identification of methods employed in addressing the issue of development of social rights of EU citizens, and provide data needed in order to assess their adequacy. It will show that legal contours of the social dimension of EU citizenship have been so far defined mainly as a consequence of a recurrent process of balancing between the goal of promoting the freedom of movement and solidarity at the EU level, and the goal of preserving MS' financial interests and their social security schemes. Over the course of time, this approach has generated no clear 'winners' or

\footnotetext{
${ }^{26}$ Welfare tourism can be described as "movement undertaken for the sole purpose of exploiting a more generous welfare system of another Member State”. Derrick Wyatt and others, Wyatt and Dashwood's European Union Law (5th edn Sweet and Maxwell, London 2006), p. 666.
} 
'losers', making it impossible to predict with any certainty future trends or dynamics in development of the social aspect of EU citizenship. At best, one can conclude that the evolution of the concept of EU citizenship has been so far dominated by "ad hoc political bargains" 27 and a case-by-case approach driven by balancing, rather than a comprehensive strategy for addressing developments in the area of social policy at the Union level.

At the MS' level, the approach towards the prospect of development of EU law in the field of social rights has been somewhat different. This is best visible in national constitutional and supreme courts' decisions dealing with the constitutionality of EU law amendments and setting guidance for all other judicial and legislative state actors. In order to identify the predominant approach applied by crucial national judicial actors in addressing EU law amendments in the area of social policy, and in order to be subsequently able to assess its adequacy, Chapter II will analyze this line of national case law.

As the analysis will show, crucial MS' judicial actors have so far employed a similar approach in addressing and conditioning actual and potential changes in EU law, including those in the area of social policy. In particular, throughout the history of European integration, national highest tribunals that have reviewed the constitutionality of Treaty amendments have developed and applied an approach that gives a priority to the preservation of the MS' sovereignty in areas of vital state interest, including the area of social policy to which the social rights of EU citizens pertain. This approach, which I term 'the sovereignty-related approach', basically amounts to conditioning any future developments in EU law upon the preservation of states' core sovereign powers.

As shown in Chapter II, the tendency of resorting to the sovereignty-related rhetoric whenever EU law amendments come at the table was not present only in the early stages of development of European integration. On the contrary, over time it seems to have become more and more popular, which is well exemplified by the recent processes of negotiation and ratification of Treaty amendments ${ }^{28}$. The recurrent application of the sovereignty-related approach in assessing the permissibility of EU law amendments under

\footnotetext{
27 See footnote 23 above, p. 337, 340, 342.

${ }^{28}$ Most notably, the process of adoption and ratification of the Lisbon Treaty, which is by far the most prominent example of the ongoing and growing trend of applying the sovereignty-related approach. See further Chapter II.
} 
national constitutional principles hardly comes as a surprise. After all, questions of limitation or transfer of sovereign powers from the MS to the European Union have been largely debated ever since the founding of the European Communities.

Yet, while the recurrent application of the sovereignty-related approach may come as no surprise, it will be argued that the adequacy of its employment in the context of EU citizens' social rights is highly questionable. The same will be argued about the methods applied by EU judicial and legislative actors. Chapter III will, thus, move from the descriptive to a critical analysis, in order to show that neither of the identified methods provides an adequate approach for defining the future development of the social aspect of EU citizenship.

As far as the methods employed at the EU level are concerned, the adherence to random political bargaining and the recurrent case-by-case approach driven by balancing show reluctance by both the Union legislator and the CJEU to comprehensively and coherently address developments in the area of social rights of EU citizens. This kind of approach has, in turn, lead to a lack of clarity, consistency and legitimacy in developing of this important aspect of the European integration. For that reason, it will be argued that the approaches employed at the EU level hardly provide an adequate basis for addressing the development of Union citizens' social rights and, in general, developing the social aspect of European integration.

The approach assumed by crucial state legal actors might, at first sight, appear as more transparent and coherent guidance. However, a closer look will reveal several serious problems attached to it. The analysis will show that highest national tribunals who developed and applied the sovereignty-related approach have repeatedly failed to clearly define the meaning of its core concept, the concept of sovereignty. They have, thus, allowed for a possibility to rely upon various different conceptions of sovereignty in its application. This has, in turn, resulted in the application of an empty standard of review, which is highly susceptible to manipulation and, thus, providing hardly any guidance to those for whom it is conceived.

In short, Chapter III will represent a critical assessment of ways in which both MS' and EU actors have been so far addressing legal developments of the concept of Union citizenship and social rights attached to it. This critique and the identification of downsides of the identified approaches will, in turn, guide the discussion on possible alternatives in the subsequent chapter. 
Chapter IV will, thus, comprise a search for more adequate ways of approaching the evolvement of the social dimension of EU citizenship and, more generally, social Europe.

As a result of this search, it will be suggested that a principle of subsidiarity may provide the needed inspiration and suitable guidance for those concerned with the future of the social dimension of EU citizenship. However, in order to do that, it will be argued that both positive and negative side of subsidiarity need to be taken into consideration. While the positive side of subsidiarity relates to the possibility of intervention of a higher entity vis-à-vis a lower entity, its negative side refers to the limits of such intervention. ${ }^{29}$ Thus far, in the context of European integration, the emphasis was put on the negative side of subsidiarity. ${ }^{30}$ In the meanwhile, its positive side, which essentially provides for a "social efficiency criterion" 31 , has been rather neglected.

It will be submitted that putting equal weight on these two inherently tied aspects of subsidiarity is not only necessary in order to ensure full respect of this fundamental principle of EU law, but also useful as it can provide the needed guidance for policy and lawmakers in the social rights' field of EU citizens. The principle of subsidiarity, comprising of both its negative and positive side, will thus be advanced as an adequate alternative for addressing the development of the social dimension of EU citizenship. It will be argued that subsidiarity can provide a suitable framework and a guiding criterion in this field due to its focus on the rights and needs of EU citizens, as well as its ability to surpass the downsides of the two currently employed approaches. By elaborating what the application of subsidiarity entails in the field of social rights of EU citizens, I will attempt to demonstrate this and justify the endorsement of this principle as a standard for addressing the future of the social aspect of Union citizenship.

To sum up, the goal of this research is to engage in a comprehensive discussion about the prospect of development of the social dimension of EU

\footnotetext{
${ }^{29}$ Ken Endo, 'The Principle of Subsidiarity: From Johannes Althusius to Jacques Delors' Hokkaido L. Rev. (1994) 44(6), 652, p. 642. As Endo explains, the word 'higher' refers to 'superior' or 'bigger', while the word 'lower' refers to 'inferior' or 'smaller'.

30 See further ibid., Chapter III.

${ }^{31}$ Didier Fouarge, Poverty and Subsidiarity in Europe: Minimum Protection from an Economic Perspective (Edward Elgar, Cheltenham 2004).
} 
citizenship and criteria suitable for defining its future contours. This kind of exercise is warranted by the current situation of crisis in Europe, which has induced some difficult questions about the future of European integration and has called for redefining of the entire European project. In addition, this is needed in order to provide legitimacy to the project of European Union citizenship, inextricably linked to European integration. 


\section{Chapter I - Addressing EU citizens' social rights developments at the European Union level}

\subsection{Introduction}

Two decades have passed since 'citizenship of the Union' was introduced as a distinct concept in EU law. ${ }^{32}$ Since then, its meaning and potential have been extensively discussed. Various authors have offered different views on what is or should be the content, the role and the purpose of EU citizenship, especially bearing in mind the broader goals of European integration. ${ }^{33}$ In that respect, Union citizenship has often been studied as a potentially

\footnotetext{
32 To be exact, it was introduced in 1992 by the Treaty on European Union (the Maastricht Treaty), Official Journal C 191 of 29 July 1992.

${ }^{33}$ See, for example, Hans Ulrich Jessurun d'Oliveira, 'European Citizenship: Its Meaning, Its Potential', in Renaud Dehousse (ed), Europe after Maastricht: An Ever Closer Union? (Law Books in Europe, Munich 1994); Ulrich K. Preuß, 'Problems of a Concept of European Citizenship' (1995) 1(3) ELJ 267; Michelle Everson, 'The Legacy of the Market Citizen', in Jo Shaw and Gillian More (eds), New Legal Dynamics of the European Union (Clarendon Press, Oxford 1995); Síofra O'Leary, The Evolving Concept of Community Citizenship: From the Free Movement of Persons to Union Citizenship (Kluwer, The Hague 1996); MacCormick Neil, 'Democracy, Subsidiarity, and Citizenship in the 'European Commonwealth" (1997) 16 Law and Philosophy 331; Joseph H.H. Weiler, 'To be a European Citizen', in Scritti in onore di Giuseppe Federico Mancini, Vol. II - Diritto dell'Unione Europea (Giuffrè, Milano 1998); Sybilla Fries and Jo Shaw, 'Citizenship of the Union: First Steps in the European Court of Justice' (1998) 4(4) Eur Pub L 544; Jo Shaw, 'The Interpretation of European Union Citizenship' (1998) 61(3) MLR 293; Jo Shaw, 'Citizenship of the Union: Towards Post-National Membership?', in the European University Institute (ed), Collected Courses of the Academy of European Law 1995, Vol. VI, Book 1 (Kluwer, The Hague 1998); Norbert Reich, 'Union Citizenship: Metaphor or Source of Rights?' (2001) 7(1) ELJ 4.
} 
important factor in dealing with the problems of 'democratic deficit' 34 and the lack of legitimacy at the EU level. 35

This is not surprising given the fact that the search for the concept itself emerged from the democratic imperative of bestowing legitimacy upon the Union. ${ }^{36}$ In fact, the very aim behind the establishment of EU citizenship was to "strengthen and consolidate European identity by greater involvement of the citizens in the Community integration process". 37 This was visible already in the early stages of the development of this concept and negotiations of specific 'citizenship' provisions in the Maastricht Treaty. During that period, assertions were repeatedly made by important political actors that the creation of Union citizenship can contribute to resolving the problem of the lack of democratic legitimacy of the Union and the democratic deficit in the European institutions, as well as strengthen the shared sense of belonging of

\footnotetext{
${ }^{34}$ As Barber explains: "The democratic deficit is a gap that is thought to exist between the individual and the institutions of Europe; an assertion that, in contrast to national governments, the European institutions are remote from the individual. This gap is believed to have implications for the legitimacy of the European project; throwing doubt on to the authority of the rules generated by European institutions, and questioning the obligation of individuals to support the Union." He adds: "The concept of European citizenship was introduced into the Treaty in an effort to alleviate $[. .$.$] the "democratic deficit"'. See Nicholas W. Barber, 'Citizenship,$ Nationalism and the European Union' (2002) 27 E.L. Rev. 241, p. 246. For a more detailed discussion on the democratic deficit see Gráinne de Búrca and Paul Craig, EU Law: Text, Cases and Materials (2nd edn OUP, Oxford 1998), pp. 155-161.

${ }^{35}$ See, for example, Síofra O'Leary, The Evolving Concept of Community Citizenship: From the Free Movement of Persons to Union Citizenship (Kluwer, The Hague 1996); Joseph H.H. Weiler, 'To be a European Citizen', in Scritti in onore di Giuseppe Federico Mancini, Vol. II - Diritto dell'Unione Europea (Giuffrè, Milano 1998); Jo Shaw, 'Citizenship of the Union: Towards Post-National Membership?', in the European University Institute (ed), Collected Courses of the Academy of European Law 1995, Vol. VI, Book 1 (Kluwer, The Hague 1998); Nicholas W. Barber, 'Citizenship, Nationalism and the European Union' (2002) 27 E.L. Rev. 241; Paul O'Neill and Susan R. Sandler, 'The EU Citizenship Acquis and the Court of Justice: Citizenship Vigilante or Merely Vigilant Treaty Guardian?' (2008) 7(3) Richmond Journal of Global Law and Business 206.

${ }^{36}$ Joseph H.H. Weiler, 'To be a European Citizen', in Scritti in onore di Giuseppe Federico Mancini, Vol. II - Diritto dell'Unione Europea (Giuffrè, Milano 1998), p. 1096. ${ }^{37} \mathrm{Http} / / /$ europa.eu/legislation_summaries/institutional_affairs/treaties/amsterdam_tr eaty/a12000_en.htm.
} 
citizens of Europe to one legal community. ${ }^{38}$

The prevalent question that arose in this context, which still remains unanswered, was whether EU citizenship can truly generate a sense of belonging and identity needed to create a European demos and, in turn, help the EU overcome its lack of legitimacy. ${ }^{39}$ To answer this question, however, one first had to resolve what we may call a 'chicken-egg dilemma', that is, the problem of what comes first, citizenship or identity. In other words, before answering the question whether EU citizenship can generate a European identity, one first had to address the preliminary theoretical issue whether the establishment of EU citizenship constitutes a necessary step in creating a European identity, or whether a minimum sense of identity and belonging to the European polity is a precondition for introducing a meaningful concept of EU citizenship.

Different answers were offered in the attempt to resolve this underlying dilemma. On the one hand, there are those who argued that a creation and expansion of the concept of EU citizenship could generate a stronger sense of belonging to the European polity and, hence, help create a European identity..$^{40}$ In that regard, some authors have suggested that "a participation and pluralist model of Union government, complemented by a nonexclusionary concept of social citizenship, might provide a means towards creating [a European] identity" 41 . According to this argument, "a form of

\footnotetext{
${ }^{38}$ For a more elaborate description of these proposals see O'Leary's overview of the negotiation process of the provisions on citizenship of the Union in the Maastricht Treaty. Síofra O'Leary, The Evolving Concept of Community Citizenship: From the Free Movement of Persons to Union Citizenship (Kluwer, The Hague 1996), pp. 23-31. ${ }^{39}$ See Jo Shaw, Law of the European Union, ( $3^{\text {rd }}$ edn, Palgrave Macmillan Law Masters 2000), p. 372.

${ }^{40}$ See, for example, Paul O'Neill and Susan R. Sandler, 'The EU Citizenship Acquis and the Court of Justice: Citizenship Vigilante or Merely Vigilant Treaty Guardian?' (2008) 7(3) Richmond Journal of Global Law and Business 206; Michelle Everson, 'The Legacy of the Market Citizen', in Jo Shaw and Gillian More (eds), New Legal Dynamics of the European Union (Clarendon Press, Oxford 1995), p. 89. However, Everson adds that the expansion of citizens' rights will not suffice to create the necessary allegiance of the EU citizens to the EU, and proposes a further development of allegiance-winning mechanisms via the medium of the EU citizenship. ${ }^{41}$ See Jo Shaw, 'Citizenship of the Union: Towards Post-National Membership?', in the European University Institute (ed), Collected Courses of the Academy of European Law 1995, Vol. VI, Book 1 (Kluwer, The Hague 1998), p. 273, citing Ian Ward, ‘(Pre)conceptions in Europan Law’ (1996) 23(2) Journal of Law and Society 198, p.
} 
European 'identity' can be generated out of the development of the conception of social citizenship" and not necessarily from "a sense of nationalism, ethnicity or regional belonging" 42 .

On those lines, Weatherill stated the following: "the very language of 'citizenship' suggests an attempt to convey something of the shifting sands of allegiance and legitimacy that flow from the deepening role of the European Union, and to add a (supplementary) European level of democratic legitimacy. It has not done very well on this score. But it could. If legitimacy involves the construction of a sense of European identity which is, first, in supplement to and not a replacement for national loyalties, and, second, built around social values, not ethnicity or nationhood, then European Citizenship has some potential for developing an appealingly inclusive notion of political belonging" 43 .

In short, this line of reasoning suggests that in order to motivate the peoples of Europe towards the Union, market citizenship needs to be buttressed with political and social rights through which Union citizens could develop a true sense of belonging and identity, and which would, in turn, enhance the democratic legitimacy of the Union. ${ }^{44}$

210. Similarly, it was suggested that it is "through (social) citizenship that the 'community' can be built, not the reverse” - see p. 273 in Jo Shaw, 'Citizenship of the Union: Towards Post-National Membership?', in the European University Institute (ed), Collected Courses of the Academy of European Law 1995, Vol. VI, Book 1 (Kluwer, The Hague 1998), citing Ulrich K. Preuß, 'Citizenship and Identity: Aspects of a Political Theory of Citizenship', in Richard Bellamy, Vittorio Bufacchi and Dario Castiglione (eds), Democracy and constitutional culture in the Union of Europe (Lothian Foundation Press, London 1995), p. 119.

42 See Jo Shaw, 'Citizenship of the Union: Towards Post-National Membership?', in the European University Institute (ed), Collected Courses of the Academy of European Law 1995, Vol. VI, Book 1 (Kluwer, The Hague 1998), p. 277.

${ }^{43}$ Stephen Weatherill, 'Competence and Complexity, Simplification and Clarification... and Legitimacy too' in Stephen Weatherill and Kalypso Nicolaidis (eds), Whose Europe? National Models and the Constitution of the European Union, Papers of a Multi-Disciplinary Conference held in Oxford in April 2003, p. 110, available at http://www.europaeum.org/files/publications/reports/WhoseEurope.pdf. ${ }^{44}$ Paul O'Neill and Susan R. Sandler, 'The EU Citizenship Acquis and the Court of Justice: Citizenship Vigilante or Merely Vigilant Treaty Guardian?' (2008) 7(3) Richmond Journal of Global Law and Business 206, pp. 211, 213. 
On the other hand, there are those who endorsed a "compromise position" according to which citizenship and identity play a mutually reinforcing role in the so-called "virtuous circle". 45 The main proponent of this view is Jo Shaw, who argued that "the institution of citizenship reinforces the sense of community, and other policy which feed into strengthening the community (eg policy on education and training for migrant workers and their families; perhaps, after the Treaty of Amsterdam, policy on unemployment) help in turn to make the existence of a form of membership more meaningful for any given community (ie the body of persons subject to EC law, or the nationals of the Member States - however one chooses to define Union citizenship)" 46 . In other words, this compromise solution of the 'chicken-egg dilemma' suggests that the existence of the concept of EU citizenship plays a vital role in the establishment of a sense of community and European identity, while, at the same time, the mechanisms which generate a European sense of belonging and identity, add meaning and value to the concept of EU citizenship.

Finally, there are those who consider that Union citizenship has a merely symbolic and ancillary role in the creation of a European identity and a sense of belonging. As described by Weiler, under this view, "the Union may belong to its citizens but no more, say, then a multinational corporation belongs to its shareholders. The introduction of citizenship on this reading is little more then a decision of the board voting for an increased dividend as a way of placating restless shareholders." ${ }^{\prime 7}$ More radically, some have even argued that there will never be a European citizenship capable of generating "the consciousness of 'an obligation toward the European common-weal"”48.

While these divergent approaches clearly demonstrate that there is no unanimity when it comes to assessing the position of Union citizenship in

\footnotetext{
45 See Jo Shaw, 'The Interpretation of European Union Citizenship' (1998) 61(3) MLR 293, pp. 316-317, Jo Shaw, 'Citizenship of the Union: Towards Post-National Membership?', in the European University Institute (ed), Collected Courses of the Academy of European Law 1995, Vol. VI, Book 1 (Kluwer, The Hague 1998), p. 266. ${ }^{46}$ See Jo Shaw, 'The Interpretation of European Union Citizenship' (1998) 61(3) MLR 293, p. 316.

${ }^{47}$ Joseph H.H. Weiler, 'To be a European Citizen', in Scritti in onore di Giuseppe Federico Mancini, Vol. II - Diritto dell'Unione Europea (Giuffrè, Milano 1998), p. 1080. 48 See Habermas' description of this skeptical view in Jurgen Habermas, 'Citizenship and National Identity: Some Reflections on the Future of Europe' (1992) 12(1) Praxis International 1, p. 9.
} 
relation to a European identity, at least one point of common accord seems to exist regarding the nature of EU citizenship, which appears as the leitmotif in discussions concerning this concept. This is the assertion that Union citizenship constitutes a dynamic and an ever-expanding concept. ${ }^{49}$ The emphasis put on its developmental and dynamical potential suggests that we should regard EU citizenship as a project never to be fully realized and always susceptible to change, depending on how the wider context in which it operates changes. Accordingly, developments surrounding the concept of EU citizenship should be understood as a never-ending 'work in progress'. ${ }^{50}$

This, however, does not imply that the contours of EU citizenship are as blurry as they were when the notion was first inserted into the Maastricht Treaty. Since then, legislative and judicial developments of the concept have given us a far clearer understanding of what its potential, its role and its meaning are. In that context, the CJEU's has played a vital role in assessing and clarifying the scope and the content of citizenship rights. Moreover, by its generous interpretation of citizenship rights, the Court gave teeth to the concept of Union citizenship, which was until then widely considered as powerless and merely symbolic in character. ${ }^{51}$

\footnotetext{
${ }^{49}$ This was initially recognized in the proposals made by the MS in the course of negotiations of the 'citizenship' provisions in the Maastricht Treaty. For a detailed description see Síofra O'Leary, The Evolving Concept of Community Citizenship: From the Free Movement of Persons to Union Citizenship (Kluwer, The Hague 1996), pp. 24, 25 . Later, this was reiterated in the academic circles by a number of authors, such as Norbert Reich, 'Union Citizenship: Metaphor or Source of Rights?' (2001) 7(1) ELJ 4, pp. 14, 23; Hans Ulrich Jessurun d'Oliveira, 'European Citizenship: Its Meaning, Its Potential', in Renaud Dehousse (ed), Europe after Maastricht: An Ever Closer Union? (Law Books in Europe, Munich 1994), p. 128, 133; Jo Shaw, 'The Interpretation of European Union Citizenship' (1998) 61(3) MLR 293, pp. 296, 308-9, 317; Ulrich K. Preuß, 'Problems of a Concept of European Citizenship' (1995) 1(3) ELJ 267, p. 280; David O'Keeffe, 'Union Citizenship' in David O'Keeffe \& Patrick M. Twomey (eds), Legal Issues of the Maastricht Treaty (Wiley Chancery Law, London 1994), p. 102, 107; and Carlos Closa, 'Citizenship of the Union and Nationality of the Member States' in David O'Keeffe \& Patrick M. Twomey (eds), Legal Issues of the Maastricht Treaty (Wiley Chancery Law, London 1994), p. 115.

${ }^{50}$ Some have, more skeptically, referred to the concept of EU citizenship as a "pie in the sky, the promise of future developments". See Hans Ulrich Jessurun d'Oliveira, 'European Citizenship: Its Meaning, Its Potential', in Renaud Dehousse (ed), Europe after Maastricht: An Ever Closer Union? (Law Books in Europe, Munich 1994), p. 141. ${ }^{51}$ See Catherine Jacqueson, 'Union citizenship and the Court of Justice: something new under the sun? Towards social citizenship' (2002) 27 E.L. Rev. 260, p. 263.
} 
The effects of developments concerning the concept of Union citizenship have been most dramatically felt in the field of social rights ${ }^{52}$, since the citizenship provisions of the Treaty revealed themselves as "notorious catalysts" in expanding social rights of Union citizens, and, more particularly, of migrant EU citizens who are not economically active ${ }^{53}$. The most notable of developments concerns the CJEU's interpretation of citizenship rights whereby the concept of EU citizenship was used to extend the application of the principle of non-discrimination on grounds of nationality to all EU citizens lawfully resident in a territory of a host MS. ${ }^{54}$ As a consequence, migrant EU citizens lawfully resident in a MS of which they are not nationals, including non-economically active ones, gained access to social and other benefits in a host MS, provided that their situation falls within the scope of EU law. 55

While it is debatable whether this expansion of citizens' rights should be perceived as the shiniest of the "hidden treasures" 56 found or, on the contrary, as opening the Pandora's box, it was clear right from the start that it affected the MS' power to regulate their welfare systems. ${ }^{57}$ The long-standing belief

${ }^{52}$ Damian Chalmers and others, European Union Law: Text and Materials (CUP, Cambridge 2006), p. 597.

${ }^{53}$ Koen Lenaerts and Tinne Heremans, 'Contours of a European Social Union in the Case-Law of the European Court of Justice' (2006) 2 EuConst 101, p. 103. Such development must have come as quite a surprise to those who (at the time) regarded the absence of any guarantees of socio-economic rights in the Union Treaty and in the provisions on Union citizenship as a sign that "the Community is not yet prepared to take a rights-based approach to social policy”. Síofra O'Leary, The Evolving Concept of Community Citizenship: From the Free Movement of Persons to Union Citizenship (Kluwer, The Hague 1996), pp. 307-308, citing Jo Shaw, 'Twin-Track Social Europe: The Inside Track', in David O'Keeffe \& Patrick M. Twomey (eds), Legal Issues of the Maastricht Treaty (Wiley Chancery Law, London 1994).

54 See Gráinne de Búrca and Paul Craig, EU Law: Text, Cases and Materials (4th edn OUP, Oxford 2008), p. 847.

55 See case C-85/96 Martínez Sala [1998] ECR I-2691 and case C-184/99 Grzelczyk [2001] ECR I-6193.

56 The term is borrowed from Hans Ulrich Jessurun d'Oliveira. See Hans Ulrich Jessurun d'Oliveira, 'European Citizenship: Its Meaning, Its Potential', in Renaud Dehousse (ed), Europe after Maastricht: An Ever Closer Union? (Law Books in Europe, Munich 1994), p. 133.

57 See, for instance, Sybilla Fries and Jo Shaw, 'Citizenship of the Union: First Steps in the European Court of Justice’ (1998) 4(4) Eur Pub L 544, pp. 552, 558 and Anne 
that the MS have full autonomy in organizing and administering their social security schemes ${ }^{58}$ was, thus, put into question.

The following sections will provide an in-depth analysis of the mentioned expansion of citizens' social rights. This analysis will be conducted in order to examine the extent to which EU citizens gained access to social benefits across the Union ${ }^{59}$, as well as to evaluate how much autonomy have the MS retained in the area of social policy after these developments in the 'citizenship field'. Ultimately, the aim of this analysis will be to identify the ways in which the Union legislator and judiciary have defined the social dimension of EU citizenship and addressed previously described tensions inherent to the social policy field ${ }^{60}$.

Pieter van der Mei, Free Movement of Persons within the European Community: CrossBorder Access to Public Benefits (Hart Publishing, Oxford 2003), p. 68.

58 Anne Pieter van der Mei, Free Movement of Persons within the European Community: Cross-Border Access to Public Benefits (Hart Publishing, Oxford 2003), p. 62.

59 Two important preliminary remarks should be made here. First, the reference to "social rights" used in this Chapter primarily concerns the rights of Union citizens to access social benefits (mainly non-contributory ones) in other MS. Given the fact that this Chapter analyses precisely the expansion of those kinds of social rights of Union citizens, my subsequent uses of terms such as "the field of social rights", "the area of social policy", "the social/welfare field", etc., will also refer to this limited notion of social rights and, more generally, social policy. Second, this Chapter will primarily be concerned with the right of access to benefits of economically inactive migrant Union citizens. This category of persons includes economically self-sufficient persons, retired persons and students. However, in part, my analysis will also cover jobseekers searching for employment in other MS. In this regard, it should be noted that jobseekers enjoy a special status under EU, which in fact places them in the category of economic migrants within the meaning of Article 45 of the TFEU (see case C138/02 Collins [2003] ECR I-2703, case C-258/04 Ioannidis [2005] I-08275, joined cases C-22/08 \& C-23/08 Vatsouras and Koupatantze [2009] ECR 00000 and case C-367/11 Prete [2012] ECR 00000). However, even though they can rely on this Article to claim equal treatment in access to benefits intended to facilitate access to employment, their right to equal treatment is subject to certain limitations (as will be explained in Section 2.2.4. below) and they are not considered as workers within the meaning of Regulation 1612/68 when they move to a host MS in search for work (see case C-138/02 Collins, paras 26-33). In that respect, it can be claimed that, even though they do constitute economic migrants, they resemble to a certain extent to non-economic migrant EU citizens, as they share certain important limitations in access to social benefits.

${ }^{60}$ See the Introductory Chapter. 


\subsection{Social rights of EU citizens - Prospects and Limitations}

\subsubsection{Establishing the general rule}

Citizenship of the Union was first established by the Maastricht Treaty in 1992.61 As a result, Article 20 of the Treaty on the Functioning of the European Union ('TFEU') now provides that every person holding the nationality of a Member State shall be a citizen of the Union. ${ }^{62}$ It follows that the criterion for inclusion within the citizenship provisions is the possession of the nationality of one or more of the EU Member States. ${ }^{63}$ Given the fact that the MS still hold the exclusive competence in conferring their nationality ${ }^{64}$, they also constitute the "exclusive gate-keepers" ${ }^{65}$ with respect to the acquisition of EU citizenship.

Article 20 further prescribes that citizenship of the Union shall be additional to national citizenship and that it shall not replace it. This suggests that the TFEU does not seek to establish a free-standing citizenship of the Union, or even less so that it tries to create "a nationality of the Union" ${ }^{6}$. Rather, the Treaty establishes an additional status for all those persons who already are and will continue to remain the nationals of one or more Member States of the EU.

\footnotetext{
61 The Treaty on European Union, Official Journal C 191 of 29 July 1992.

62 See Article 20, Part Two of the Treaty on the Functioning of the European Union ('TFEU'), Consolidated versions of the Treaty on European Union and the Treaty on the Functioning of the European Union, Official Journal C 115 of 9 May 2008.

${ }^{63}$ David O'Keeffe, 'Union Citizenship' in David O'Keeffe \& Patrick M. Twomey (eds), Legal Issues of the Maastricht Treaty (Wiley Chancery Law, London 1994), p. 91. ${ }^{64}$ However, even though the CJEU's case law confirms that it is for each MS to lay down the conditions for acquisition and loss of nationality, this competence needs to be exercised with due regard to EU law (see case C-369/90 Micheletti and Others [1992] ECR I-1239, para 10; case C-179/98 Mesbah [1999] ECR I-7955, paragraph 29; case C-192/99 Kaur [2001] ECR I-1237, para 19; case C-200/02 Zhu and Chen [2004] ECR I-9925, para 37 and case C-135/08 Rottmann [2010] ECR 00000, paras $45,48)$.

${ }^{65}$ Joseph H.H. Weiler, 'To be a European Citizen', in Scritti in onore di Giuseppe Federico Mancini, Vol. II - Diritto dell'Unione Europea (Giuffrè, Milano 1998), p. 1070. ${ }^{66}$ David O'Keeffe, 'Union Citizenship' in David O'Keeffe \& Patrick M. Twomey (eds), Legal Issues of the Maastricht Treaty (Wiley Chancery Law, London 1994), p. 91.
} 
As far as the substantive content of the concept of Union citizenship is concerned, Article 20 announces that citizens of the Union shall enjoy the rights and be subject to the duties imposed by the Treaties. ${ }^{67}$ In that regard, this and the following articles list and elaborate on some specific citizenship rights, such as the right to move and reside freely within the territory of the Member States, the right to vote and to stand as a candidate at municipal elections and in elections to the European Parliament in the Member State of residence, the right to diplomatic or consular protection, and, finally, the right to petition the European Parliament, apply to the Ombudsman, and address the institutions and advisory bodies of the Union and obtain their reply. ${ }^{6} 8$

However, the broad reference to the rights conferred by the Treaties in Article 20, indicates that the rights listed in the subsequent articles are not all that the concept of EU citizenship has to offer to the peoples of Europe. On the contrary, it suggests that, when looking for the bundle of rights attached to the concept of EU citizenship, one should have in mind the Treaty as a whole. 69

At the time the concept was first introduced in EU law it was clear that the right to free movement is at the nucleus of EU citizenship ${ }^{70}$ and that

\footnotetext{
${ }^{67}$ It is worth noting that even though Article 20(2) makes explicit reference to the duties imposed by the Treaties, unlike in the case of citizenship rights, it does not further specify these duties. When looking at other Articles of the Treaties, citizens' duties in fact prove to be non-existent. Given the fact that Article 25 of the TFEU provides only for a possibility of adding new citizenship rights, not imposing duties, it seems that the prospect of introduction of EU citizens' duties is highly unlikely in the near future. See further David O'Keeffe, 'Union Citizenship' in David O'Keeffe \& Patrick M. Twomey (eds), Legal Issues of the Maastricht Treaty (Wiley Chancery Law, London 1994), p. 90.

${ }^{68}$ See Article 20-24, Part Two of the TFEU, Official Journal C 115 of 9 May 2008.

${ }^{69}$ See Hans Ulrich Jessurun d'Oliveira, 'European Citizenship: Its Meaning, Its Potential', in Renaud Dehousse (ed), Europe after Maastricht: An Ever Closer Union? (Law Books in Europe, Munich 1994), p. 132. Also see Síofra O'Leary, The Evolving Concept of Community Citizenship: From the Free Movement of Persons to Union Citizenship (Kluwer, The Hague 1996), p. 105.

${ }^{70}$ See Ibid.; Michelle Everson, 'The Legacy of the Market Citizen', in Jo Shaw and Gillian More (eds), New Legal Dynamics of the European Union (Clarendon Press, Oxford 1995), p. 73; Jo Shaw, 'Citizenship of the Union: Towards Post-National Membership?', in the European University Institute (ed), Collected Courses of the Academy of European Law 1995, Vol. VI, Book 1 (Kluwer, The Hague 1998), p. 246 citing B. Wilkinson, 'Towards European Citizenship? Nationality, Discrimination and Free Movement of Workers in the European Union' (1995) 1 Eur Pub L 417; David
} 
citizenship rights become relevant mainly when EU citizens travel abroad ${ }^{71}$. Yet, the precise meaning of the broad reference to other rights in the Treaty was yet to be determined. This uncertainty about the content and meaning of citizenship rights was clearly expressed in the academic literature published shortly after the concept of EU citizenship was introduced in EU law. ${ }^{72}$ While some of the works published in that period reveal quite a strong skepticism about the prospect of expansion of citizenship rights beyond those explicitly conferred by the Maastricht Treaty ${ }^{73}$, others have quite convincingly predicted the expansion of citizenship rights, especially having in mind the role for the right to non-discrimination on grounds of nationality, now provided by Article 18 of the TFEU. ${ }^{74}$

O'Keeffe, 'Union Citizenship' in David O'Keeffe \& Patrick M. Twomey (eds), Legal Issues of the Maastricht Treaty (Wiley Chancery Law, London 1994), p. 93; Mark Bell, Anti-discrimination law and the European Union (OUP, Oxford 2002), p. 18; and Miguel Poiares Maduro, 'Europe's Social Self: The Sickness Unto Death' in Jo Shaw (ed), Social Law and Policy in an Evolving European Union (Hart Publishing, Oxford 2000), p. 332.

${ }^{71}$ See Jo Shaw, 'The Interpretation of European Union Citizenship' (1998) 61(3) MLR 293, p. 298, citing Rainer Baubock, 'Citizenship and National Identities in the European Union', Harvard Jean Monnet Working Paper 4/97. Also see Catherine Jacqueson, 'Union citizenship and the Court of Justice: something new under the sun? Towards social citizenship' (2002) 27 E.L. Rev. 260, pp. 279-281. This issue has been recently addressed in the Case C-434/09 McCarthy [2011] ECR I-0000. There, the Court has ruled that Directive 2004/38/EC applies only in situations where a citizen moves from one Member State to another. As far as the application of Article 21 of the TFEU is concerned, the Court has made it clear that this provision is not applicable to a Union citizen who has never exercised his right of free movement, unless the situation of that citizen includes the application of national measures that "would have the effect of depriving him of the genuine enjoyment of the substance of the rights conferred by virtue of his status as a Union citizen or of impeding the exercise of his right of free movement and residence within the territory of the Member States" (para 57).

72 See above footnote 33 .

${ }^{73}$ While D'Oliveira argued that the dynamism of the concept of Union citizenship is "a pie in the sky", Hans Ulrich Jessurun d'Oliveira, 'European Citizenship: Its Meaning, Its Potential', in Renaud Dehousse (ed), Europe after Maastricht: An Ever Closer Union? (Law Books in Europe, Munich 1994), p. 141, Reich observed that Union citizenship has remained a metaphor and that it is yet to be seen whether it can become a genuine source of rights, Norbert Reich, 'Union Citizenship: Metaphor or Source of Rights?' (2001) 7(1) ELJ 4, p. 23.

${ }^{74}$ See Jo Shaw, 'The Interpretation of European Union Citizenship' (1998) 61(3) MLR 293, p. 298 and Jo Shaw, 'Citizenship of the Union: Towards Post-National 
Shortly after these predictions were made, the CJEU's case law confirmed that they were correct. It was in Martínez Sala ${ }^{75}$, one of its groundbreaking decisions, that the CJEU clarified the role of the right to non-discrimination in relation to the citizenship rights. By interpreting the right to reside and move freely (now provided by Article 21 of the TFEU) in conjunction with the right not to be discriminated on grounds of nationality (now provided by Article 18 of the TFEU), the CJEU established a rule whereby EU citizens lawfully resident in a MS other than that of their origin, have the right not to be discriminated on grounds of nationality, in all situations falling within the scope of EU law. ${ }^{76}$

Membership?', in the European University Institute (ed), Collected Courses of the Academy of European Law 1995, Vol. VI, Book 1 (Kluwer, The Hague 1998), pp. 247-8. Also see Síofra O'Leary, The Evolving Concept of Community Citizenship: From the Free Movement of Persons to Union Citizenship (Kluwer, The Hague 1996), pp. 16, 104, 105, 118,134 . Such predictions were in line with certain proposals made in course of the negotiations of the provisions on EU citizenship. In particular, they were in line with the proposal which involved inserting the principle of non-discrimination on grounds of nationality under a specific title devoted to the concept of EU citizenship in the Treaty. This proposal, as O'Leary argues, “emphasized the principle of equal treatment as part of the personal status of citizens and not simply as a means to regulate the functioning of the Treaty". Síofra O'Leary, The Evolving Concept of Community Citizenship: From the Free Movement of Persons to Union Citizenship (Kluwer, The Hague 1996), p. 28. Moreover, these predictions seemed to be in line with the soft-law measures adopted shortly after the concept of Union citizenship was established in EU law, namely with the Commission's Report on the Citizenship of the Union published in 1993. In this Report, the Commission has asserted that the Treaty provision providing for the citizens' right to move freely within the Union (at the time, Article 8(a)(1) TEC) "builds on the fundamental ban on discrimination on grounds of nationality”, thus emphasizing the role of the non-discrimination guarantee in relation to the citizen's rights. See ibid., p. 131, citing Commission (EC), 'Report from the Commission on the Citizenship of the Union' COM (93) 702 final, 21 December 1993. Finally, an important incentive in this regard can be found in the Advocate General Jacobs' famous prophetic phrase, whereby he declared that "Freedom from discrimination on grounds of nationality is the most fundamental right conferred by the Treaty and must be seen as a basic ingredient of Union citizenship". See para 24 of the Opinion of Advocate General Jacobs in the case C274/96 Bickel and Franz [1998] ECR I-7637.

${ }^{75}$ Case C-85/96 Martínez Sala [1998] ECR I-2691.

${ }^{76}$ Ibid., para 63. At the time, the Court spoke of the scope of Community law, as the interpreted Treaty provisions constituted a part of the Treaty Establishing the European Community. 
Not only was this the first time that the Court relied directly on the provisions concerning EU citizenship, but it was also the first instance in which the Court revealed the potential of the citizenship provisions. ${ }^{77}$ Some even claimed that, by this revolutionary decision, the Court finally put an end to unequal treatment of Union citizens based on their economic status. ${ }^{78}$

This case concerned Mrs. Martínez Sala, a Spanish national living in Germany, who was refused, by the German authorities, a child-raising allowance, on the ground that she did not posses a valid residence permit or a residence entitlement. ${ }^{79}$ Since the German law only imposed the requirement of having a residence permit in order to receive a child-raising allowance on non-nationals, the question arose whether Mrs. Martínez Sala could rely on Article 18 of the TFEU to claim equal treatment with German nationals in access to this non-contributory social benefit.

Leaving it up to the national court to determine whether Mrs. Martínez Sala is a worker within the meaning of Article 45 of the TFEU or Regulation No. $1612 / 68$, or an employed or self-employed person within the meaning of Regulation No. 1408/71, the Court went on to consider the question before it under the presumption that Mrs. Martínez Sala constitutes a non-economic migrant, falling in neither of these categories. ${ }^{80}$

The Court first observed that, for the purposes of the recognition of the right of residence, a residence permit can only have declarative and probative, not constitutive force as was the case here with respect to the right to the social benefit in question. ${ }^{81}$ Thus, the Court proceeded to conclude that requiring a national of another MS to produce a residence permit in order to have access to the benefit, when German nationals are not required to produce any document of that kind, amounts to unequal treatment prohibited by Article 18 of the TFEU, in the sphere of the application of the Treaty and in the absence of any justification. ${ }^{82}$

\footnotetext{
77 Catherine Jacqueson, 'Union citizenship and the Court of Justice: something new under the sun? Towards social citizenship' (2002) 27 E.L. Rev. 260, p. 264.

78 Ibid.

${ }^{79}$ Case C-85/96 Martínez Sala [1998] ECR I-2691, paras 13-16.

${ }^{80}$ While Mrs. Martínez Sala performed various job in intervals preceeding the time of her application for a child-raising allowance, at the time she applied she did not work and she received social assistance. Case C-85/96 Martínez Sala [1998] ECR I-2691, para 13.

${ }^{81}$ Ibid., para 53.

82 Ibid., para $54-5$.
} 
Yet, in order for Mrs. Martínez Sala to be able to rely on the principle of equal treatment provided by Article 18, her situation had to fall within the scope of EU law ${ }^{83}$. In that regard, the Court made a distinction between the scope ratione materiae and the scope ratione personae of the Treaty, and analyzed each in turn.

As regards the scope ratione materiae, the Court somewhat curiously concluded that the situation at hand falls within the scope of EU law, since the benefit in question constitutes a social advantage within the meaning of Article 7(2) of Regulation 1612/68 and a family benefit within the meaning of Article 4(1)(h) of Regulation 1408/71.84 The Court reached this conclusion even though it was not clear whether the conditions for the application of these Regulations were fulfilled, more specifically, whether Mrs. Martínez Sala could be regarded as a worker or an employee. 85

The Court then proceeded to analyze whether Mrs. Martínez Sala falls within the scope ratione personae of the Treaty. In that context, it stated that if the national court were to conclude that Mrs. Martínez Sala constitutes a worker or an employed person within the meaning of one of the two before mentioned Regulations, the unequal treatment would clearly be incompatible with Articles 45 and 49 of the TFEU. 86 Since it was unclear whether this was the case, the Court went on to consider whether Mrs. Martínez Sala could, as a non-economic migrant, rely on the right to equal treatment provided by Article 18 of the TFEU.

\footnotetext{
${ }^{83}$ As previously mentioned, at the time, the Court referred to the scope ratione materiae and personae of Community law, since the relevant Treaty provisions constituted a part of the Treaty Establishing the European Community. ${ }^{84}$ Case C-85/96 Martínez Sala [1998] ECR I-2691, paras 26-7. This reasoning was later replaced by a more comprehensive one, according to which situations falling within the material scope of EU law "include those involving the exercise of fundamental freedoms guaranteed by the Treaty and those involving the exercise of the right to move and reside freely in another Member State”. Case C-184/99 Grzelczyk [2001] ECR I-6193, para 33.

${ }^{85}$ Catherine Jacqueson, 'Union citizenship and the Court of Justice: something new under the sun? Towards social citizenship' (2002) 27 E.L. Rev. 260, p. 265. See further, Sybilla Fries and Jo Shaw, 'Citizenship of the Union: First Steps in the European Court of Justice' (1998) 4(4) Eur Pub L 544, p. 543. ${ }^{86}$ Case C-85/96 Martínez Sala [1998] ECR I-2691, para 58.
} 
The Court first observed that, even though Martínez Sala had not been issued a residence permit, she was a lawful resident in Germany, since she had been authorized to reside there. ${ }^{87}$ Based on this, the Court found that as a national of a MS lawfully residing in the territory of another MS, Mrs. Martínez Sala fell within the scope ratione personae of the Treaty provisions on citizenship. ${ }^{88}$ It thus follows from the Court's analysis that as long as a Union citizen is authorized to reside or is by other means lawfully resident in a host MS, he or she will be considered to fall within the scope ratione personae of EU law. Whether the right to lawful residence of a particular claimant originates in national law, EU law, or even international law is completely irrelevant for this purpose. 89

The Court then proceeded to conclude that, since Article 20 of the TFEU attaches to the status of the EU citizen rights and duties laid down by the Treaty, including the right not to be discriminated on grounds of nationality provided by Article 18 TFEU, any EU citizen lawfully resident in the host MS can rely on Article 18 to claim equal treatment in situations falling within the scope of application ratione materiae of the Treaty. ${ }^{90}$

This reading of Articles 21 and 18 of the TFEU in conjunction, to significantly expand the scope of EU law, was not only seen as a very broad and generous interpretation of EU law, but also as a major novelty in the CJEU's approach, which is difficult to square with some of the earlier case law. ${ }^{91}$ The innovative and revolutionary character of this reasoning becomes even more obvious if one has in mind the previously described way in which

\footnotetext{
${ }^{87}$ It seems that the Court has based this conclusion on the fact that Mrs. Martínez Sala obtained the documents certifying that the extension of her residence right had been applied for, and on the fact that no deportation measures were taken against her. See Ibid., paras 14, 47, 53 and 60-1.

88 Ibid., para 61.

${ }^{89}$ See Catherine Jacqueson, 'Union citizenship and the Court of Justice: something new under the sun? Towards social citizenship' (2002) 27 E.L. Rev. 260, p. 267. ${ }^{90}$ Case C-85/96 Martínez Sala [1998] ECR I-2691, paras 62-3.

${ }^{91}$ Namely, with its judgment in the case 316/85 Lebon [1987] ECR 2811, in which the Court "appeared to set strict limits upon the scope of equal treatment principle for those without independent means unless they were the dependants of migrant workers themselves”. Sybilla Fries and Jo Shaw, 'Citizenship of the Union: First Steps in the European Court of Justice' (1998) 4(4) Eur Pub L 544, p. 550. See further Catherine Jacqueson, 'Union citizenship and the Court of Justice: something new under the sun? Towards social citizenship' (2002) 27 E.L. Rev. 260, pp. 265-6.
} 
the Court has brought the benefit and the person in question within the scope of EU law, to be able to bring the personal and the material scope together in this particular case. ${ }^{92}$

All in all, the application of this new rule to Mrs. Martínez Sala's situation allowed her to claim equal treatment in access to social benefits on the same terms as German nationals. More generally speaking, this meant that EU citizens lawfully residing in a host MS, including non-economic migrants, suddenly gained access to social benefits under the same conditions as nationals of their host MS.

While the exact implications were not entirely clear at the time, ${ }^{93}$ what seemed apparent was that, as a consequence of this newly established rule, the MS' freedom to regulate access to their welfare systems was somewhat limited. ${ }^{94}$ Still, at the time, doubts were expressed as to whether this rule would stick or whether the Martínez Sala ruling was, in fact, closely tied to the circumstances of this case, and thus not enunciating a lasting legal principle..$^{95}$ Shortly after, these doubts were cast away by the Court's ruling in the Grzelczyk case ${ }^{96}$, where the Martínez Sala rule was confirmed and further clarified.

In Grzelczyk, the Court dealt with the question whether Articles 21 and 18 of the TFEU preclude national legislation which makes the entitlement to a minimum subsistence allowance (a non-contributory benefit referred to as

\footnotetext{
92 See further ibid.

${ }^{93}$ See Derrick Wyatt and others, Wyatt and Dashwood's European Union Law (5th edn Sweet and Maxwell, London 2006), p. 667.

${ }^{94}$ See further Sybilla Fries and Jo Shaw, 'Citizenship of the Union: First Steps in the European Court of Justice' (1998) 4(4) Eur Pub L 544, pp. 552, 558; Anne Pieter van der Mei, Free Movement of Persons within the European Community: Cross-Border Access to Public Benefits (Hart Publishing, Oxford 2003), pp. 62, 68.

${ }^{95}$ See Sybilla Fries and Jo Shaw, 'Citizenship of the Union: First Steps in the European Court of Justice' (1998) 4(4) Eur Pub L 544, pp. 558-9. With respect to the future application and the effects of this rule, Fries and Shaw stated that "it would be wrong to read too much into one case which could, in any event, be confined quite narrowly upon its facts, or treated as a policy decision influenced by the situation of one needy individual.”, at p. 558. See further Catherine Jacqueson, “Union citizenship and the Court of Justice: something new under the sun? Towards social citizenship' (2002) 27 E.L. Rev. 260, p. 269. ${ }^{96}$ Case C-184/99 Grzelczyk [2001] ECR I-6193.
} 
'minimex') in the case of nationals of MS other than the host state, conditional on their falling within the scope of Regulation 1612/68, when no such condition applies to nationals of the host MS. ${ }^{97}$ More concretely, the Court analyzed whether and on which basis Mr. Grzelczyk, a French student studying and lawfully residing in Belgium, could successfully challenge the decision of the Belgian authorities withdrawing the payment of minimex, because he did not fulfill the required condition of being a worker within the meaning of Regulation 1612/68.

The requirement imposed by the Belgian legislation clearly constituted discrimination on the ground of nationality. 98 The Court thus went on to consider whether a person such as Mr. Grzelczyk could rely on Article 18 to claim equal treatment with Belgian nationals in access to the benefit in question.

While the details of the Court's analysis will be described in the following section, it suffices to say here that it was in relation to this question that the CJEU reaffirmed its Martínez Sala ruling. In particular, it stated once more that "a citizen of the European Union, lawfully resident in the territory of a host Member State, can rely on Article 6 of the Treaty [now Article 18 of the TFEU] in all situations which fall within the scope ratione materiae of Community law"99. In addition, the Court clarified that situations which fall within the scope ratione materiae of EU law "include those involving the exercise of fundamental freedoms guaranteed by the Treaty and those involving the exercise of the right to move and reside freely in another Member State"100.

Reaffirming and applying the Martínez Sala reasoning to this particular case, suggested that the established rule covers not only non-workers, such as presumably Mrs. Martínez Sala, but also students who study in a MS other than that of their origin. In that respect, the Court asserted that "the fact that a Union citizen pursues university studies in a Member State other than the State of which he is a national cannot, of itself, deprive him of the possibility of relying on the prohibition of all discrimination on grounds of nationality

\footnotetext{
97 Ibid., para 19.

98 Ibid., para 29.

99 Ibid., para 32.

${ }^{100}$ Ibid., para 33.
} 
laid down in Article 6 of the Treaty [now Article 18 of the TFEU]"101.

Besides restating its Martínez Sala reasoning, based on the reading of Articles 18 and 21 in conjunction ${ }^{102}$, the Court also proclaimed one of its famous phrases, later repeated as a mantra in the subsequent cases concerning citizenship rights. ${ }^{103}$ It stated: "Union citizenship is destined to be the fundamental status of nationals of the Member States, enabling those who find themselves in the same situation to enjoy the same treatment in law irrespective of their nationality, subject to such exceptions as are expressly provided for" 104 .

At that point, a general rule seemed to have been established. This rule, later relied on by the CJEU in a number of cases ${ }^{105}$, can be summarized in the terms of a simple formula: EU citizenship plus lawful residence in a host MS plus a situation within the scope ratione materiae of EU law equals access to Article 18 equal treatment guarantee.

According to some, this rule established "something close to a universal nondiscrimination right including access to all welfare benefits", by which the Court removed an important barrier to 'welfare tourism'. ${ }^{106}$ It is true that the application of this rule limited the MS' regulatory power in the area of social policy. Yet, the MS were not left entirely powerless in restricting access of Union migrants to their welfare systems. On the contrary, EU law provided the MS with a number of defense mechanisms, elaborated by EU legislation and the CJEU's subsequent case law. These defense mechanisms enabled the MS to 'escape', to a certain extent, the consequences of this newly established rule.

101 Ibid., para 36.

102 Ibid., paras 30, 32, 37.

${ }^{103}$ Robin C.A. White, 'Free Movement, Equal Treatment, and Citizenship of the Union’ (2005) 54 ICLQ 885, p. 887. Also see Gráinne de Búrca and Paul Craig, EU Law: Text, Cases and Materials (4th edn OUP, Oxford 2008), p. 848.

${ }^{104}$ Case C-184/99 Grzelczyk [2001] ECR I-6193, para 31. Emphasis added.

105 Such as the case C-656/02 Trojani [2004] ECR I-7573, case C-209/03 Bidar [2005] ECR I-2119 and case C-158/07 Förster [2008] ECR 00000.

106 Catherine Jacqueson, 'Union citizenship and the Court of Justice: something new under the sun? Towards social citizenship' (2002) 27 E.L. Rev. 260, p. 267, citing Sybilla Fries and Jo Shaw, 'Citizenship of the Union: First Steps in the European Court of Justice’ (1998) 4(4) Eur Pub L 544, p. 536. 
In the following sections, I will explore the relevant elements of the equation summarizing the general rule. I will start with the analysis of the lawful residence requirement, then proceed to the condition requiring a situation to fall within the scope ratione materiae of EU law and, finally, end with the analysis of the equal treatment guarantee and its derogations. This will be done in order to describe the extent of the expansion of solidarity and citizens' social rights at the EU level, and in order to reveal the limitations imposed on the MS' freedom to regulate access to their welfare systems. Such an analysis will, in turn, provide valuable insights into ways in which the Union legislator and the CJEU have so far defined the scope and the content of the social dimension of EU citizenship.

\subsubsection{The lawful residence requirement}

In order to be able to rely on the Article 18 equal treatment guarantee, noneconomic migrant EU citizens need to acquire the status of lawful residents in their host MS. In other words, migrant EU citizens who do not constitute workers or self-employed persons and, thus, cannot rely on EU law provisions protecting these categories of persons from discrimination on grounds of nationality, can instead rely on Article 18 to claim equal treatment in access to social benefits on the same terms as the host MS' nationals. However, to do that, they have to fall within the personal scope of Article 21 of the TFEU. As previously described, this requirement follows from the Court's reasoning whereby Articles 18 and 21 are to be read in conjunction.

Before proceeding to the analysis of EU law conditions for acquiring lawful residence, some important details concerning the specific meaning of the lawful residence requirement should be mentioned. By and large, these specifics have been elaborated in the CJEU's case law concerning citizenship rights.

First, the CJEU has acknowledged that in order to qualify as a person falling within the scope ratione personae of the Treaty, a Union citizen does not necessarily have to base his or her lawful residence on Article 21, or on the secondary legislation adopted to implement it ${ }^{107}$. Instead, as clarified in the

\footnotetext{
${ }^{107}$ Namely, on Directive (EC) 2004/38 of the European Parliament and of the Council on the right of citizens of the Union and their family members to move and reside freely within the territory of the Member States amending Regulation (EEC) No 1612/68 and repealing Directives 64/221/EEC, 68/360/EEC, 72/194/EEC,
} 
Martínez Sala judgment, lawful residence can also be derived from national legislation of a host MS. ${ }^{108}$ It follows that regardless of whether a migrant EU citizen acquired his or her status of lawful resident on the basis of EU legislation or, alternatively, on the basis of national provisions, he or she will be considered to fall within the personal scope of EU law and will, consequently, be able to rely on Article 18 of the TFEU.109

Second, the Court has recognized that the right to reside provided by Article 21 is conferred directly on every Union citizen by a clear and precise provision of the Treaty. ${ }^{110}$ In that regard, following its settled case law ${ }^{111}$, the Court asserted that the existence of limitations and conditions does not prevent Article 21 from conferring on individuals a directly effective right of residence, which is enforceable by them and which the national courts must protect. ${ }^{112}$

Finally, the Court has made it clear that, for the purposes of recognition of the residence right, a residence permit only has a declaratory and probative, not constitutive force. ${ }^{113}$

While all these points clearly make it easier for a Union citizen to satisfy the lawful residence requirement, it should be pointed out that EU law does not

73/148/EEC, 75/34/EEC, 75/35/EEC, 90/364/EEC, 90/365/EEC and 93/96/EEC [2004] OJ L 158/77. Hereinafter, 'the Citizens' Rights Directive'.

108 This was later confirmed in the Trojani case, C-656/02 [2004] ECR I-7573. See further Anne Pieter van der Mei, Free Movement of Persons within the European Community: Cross-Border Access to Public Benefits (Hart Publishing, Oxford 2003), p. 145, citing Sybilla Fries and Jo Shaw, 'Citizenship of the Union: First Steps in the European Court of Justice' (1998) 4(4) Eur Pub L 544; Robin C.A. White, 'Free Movement, Equal Treatment, and Citizenship of the Union' (2005) 54 ICLQ 885, p.895 and Robin C.A. White, 'Citizenship of the Union, Governance, and Equality' (2006) 29 Fordham Int'l L.J. 790, p. 809.

${ }^{109}$ Case C-656/02 Trojani [2004] ECR I-7573, paras 37-40.

${ }^{110}$ Case C-413/99 Baumbast [2002] ECR I-07091, para 84.

${ }^{111}$ According to this case law, the existence of limitations and conditions to a certain right cannot automatically deprive this right of its direct effect, since the application of limitations and conditions is subject to a judicial control. See case 41/74 Van Duyn v Home Office [1974] ECR 1337, para 7. See further Catherine Jacqueson, 'Union citizenship and the Court of Justice: something new under the sun? Towards social citizenship' (2002) 27 E.L. Rev. 260, p. 274.

112 Case C-413/99 Baumbast [2002] ECR I-07091, paras 85, 86.

${ }^{113}$ See case C-85/96 Martínez Sala, [1998] ECR I-2691, para 53. 
leave the MS entirely powerless in limiting the number of new residents on their territory. EU law, in particular, secondary Union legislation provides the MS with several defense mechanisms in relation to the lawful residence requirement.

In the following sections, I will explore the existing defense mechanisms and analyze the limitations in their application.

\subsubsection{Defense mechanisms related to the lawful residence requirement}

The rights of economic migrants to enter and reside in a host MS has "always" been free from restrictions. ${ }^{114}$ In particular, economically active Union citizens have always been covered by provisions guaranteeing free movement of persons and have, consequently, enjoyed extensive residency rights in a host MS.115 As a corollary of their lawful residence right, they also gained the right to equal treatment in access to social advantages, in all situations falling within the scope of the provisions on free movement of persons. ${ }^{116}$ Given the fact that such residents were fully assimilated into the welfare society of their host MS, even prior to the introduction of Union citizenship, this concept seems to have added little to their legal rights. ${ }^{117}$

114 This unlimited right, in other words, exists in the case of those migrant EU citizens who move to another Member State to exercise an economic activity as workers or self-employed persons. Derrick Wyatt and others, Wyatt and Dashwood's European Union Law (5th edn Sweet and Maxwell, London 2006), pp. 664-5. Pursuant to Article 7 of Directive 2004/38, these migrant EU citizens have the right to enter and reside freely in a host Member State, without being subject to further restrictions.

${ }^{115}$ Michael Dougan and Eleanor Spaventa, 'Educating Rudy and the (Non-) English Patient: A Double Bill on Residency Rights under Article 18 EC' (2003) 28(5) E.L. Rev. 699, p. 699. See further Anne Pieter van der Mei, Free Movement of Persons within the European Community: Cross-Border Access to Public Benefits (Hart Publishing, Oxford 2003).

116 See Michael Dougan and Eleanor Spaventa, 'Educating Rudy and the (Non-) English Patient: A Double Bill on Residency Rights under Article 18 EC' (2003) 28(5) E.L. Rev. 699, p. 699; Anne Pieter van der Mei, Free Movement of Persons within the European Community: Cross-Border Access to Public Benefits (Hart Publishing, Oxford 2003), pp. 36, 128-130; and Koen Lenaerts, 'European Union Citizenship, National Welfare Systems and Social Solidarity’ (2011) 18(2) Jurisprudence 397, p. 399. Also see Article 24 of Directive 2004/38.

117 Michael Dougan and Eleanor Spaventa, 'Educating Rudy and the (Non-) English Patient: A Double Bill on Residency Rights under Article 18 EC’ (2003) 28(5) E.L. Rev. 699, p. 700. 
Things are quite different as far as non-economic EU migrants are concerned. ${ }^{118}$ Their right to reside freely in the territory of a host MS was never free from restrictions. Even at the present stage of development, EU law subjects their residence right to certain limitations and conditions, expressly provided for in Directive 2004/38 ('the Citizens' Rights Directive') in accordance with Article 21(1) of the TFEU119. Thus, unless a host MS decides to adopt and apply more favorable national provisions regarding noneconomic migrant Union citizens who seek to establish lawful residence in its territory, the limitations and conditions provided for by secondary EU legislation will apply. 120

The Citizens' Rights Directive distinguishes three types of lawful residence. Limitations and conditions differ accordingly.

The first type is the "right of residence for up to three months", provided for by Article 6 of the Citizens' Rights Directive. According to this provision, "Union citizens shall have the right of residence on the territory of another Member State for a period of up to three months without any conditions or any formalities other than the requirement to hold a valid identity card or passport"121.

At first sight, it seems as though the right of temporary residence enshrined in Article 6 is free from restrictions. However, a closer look at other provisions of the Citizens' Rights Directive, and particularly Article 14, reveals that this is not the case. According to paragraph 1 of this Article, "Union citizens and their family members shall have the right of residence provided for in Article

\footnotetext{
118 By non-economic migrants, I mean primarily the economically self-sufficient, the retired and students. In other words, the term "non-economically active" refers to those Union citizens who are not considered as workers or self-employed persons and, therefore, cannot rely on the EU law provisions guaranteeing equal treatment in access to social advantages to those categories of persons. See above footnote 59. 119 Article 21(1) of the TFEU prescribes that "Every citizen of the Union shall have the right to move and reside freely within the territory of the Member States, subject to the limitations and conditions laid down in the Treaties and by the measures adopted to give them effect." Emphasis added.

120 The Citizens' Rights Directive prescribes that it does not affect more favorable national provisions. See Recital 29 of Directive 2004/38.

${ }^{121}$ Article 6 of Directive 2004/38. This right is also commonly referred to as the right to temporary residence. See, for example, Derrick Wyatt and others, Wyatt and Dashwood's European Union Law (5th edn Sweet and Maxwell, London 2006), p. 676.
} 
6, as long as they do not become an unreasonable burden on the social assistance system of the host Member State"122. It follows that if a host State decides to confer social assistance to its temporary residents, it is open to this MS to terminate such residence should the migrant Union citizen rely 'excessively' on its social security system. ${ }^{123}$ Since this provision clearly aims at protecting the MS' welfare schemes from potential dangerous intrusions of Union migrants during their initial period of residence, it can be identified as the first example of the mentioned defense mechanisms.

Similar, but more elaborate examples of such defense mechanisms can be found in relation to the second type of lawful residence, the "right of residence for more than three months". Article 7(1) of the Citizens' Rights Directive prescribes limitations and lists a number of conditions that need to be satisfied by non-economic migrant Union citizens who wish to reside in the territory of a host MS for a period longer then three months.

Accordingly, migrant EU citizens who do not constitute workers or selfemployed persons ${ }^{124}$ can reside on the territory of another Member State for more three months only if they: 1) "have sufficient resources for themselves and

122 Article 14(1) of Directive 2004/38. Emphaisis added.

${ }^{123}$ Derrick Wyatt and others, Wyatt and Dashwood's European Union Law (5th edn Sweet and Maxwell, London 2006), p. 677. In this regard, it is important to note that the MS are not obliged to confer entitlement to social assistance during the first three months of residence. This derogation from the equal treatment principle, provided for by Article 24(2) of the Citizens' Rights Directive, will be analyzed in more detail in the section 2.2.4. below, which deals with the defense mechanisms existing in relation to the equal treatment guarantee.

${ }^{124}$ It should be noted in this respect that, for the purpose of Article 7 of the Citizens' Rights Directive, "a Union citizen who is no longer a worker or self-employed person shall retain the status of worker or self-employed person in the circumstances where:

(a) he/she is temporarily unable to work as the result of an illness or accident; (b) he/she is in duly recorded involuntary unemployment after having been employed for more than one year and has registered as a job-seeker with the relevant employment office; (c) he/she is in duly recorded involuntary unemployment after completing a fixed-term employment contract of less than a year or after having become involuntarily unemployed during the first twelve months and has registered as a jobseeker with the relevant employment office. In this case, the status of worker shall be retained for no less than six months; (d) he/she embarks on vocational training. Unless he/she is involuntarily unemployed, the retention of the status of worker shall require the training to be related to the previous employment." Article 7(3) of Directive 2004/38. 
their family members not to become a burden on the social assistance system of the host Member State during their period of residence and have comprehensive sickness insurance cover in the host Member State" 125; or 2) "are enrolled at a private or public establishment, accredited or financed by the host Member State on the basis of its legislation or administrative practice, for the principal purpose of following a course of study, including vocational training; and have comprehensive sickness insurance cover in the host Member State and assure the relevant national authority, by means of a declaration or by such equivalent means as they may choose, that they have sufficient resources for themselves and their family members not to become a burden on the social assistance system of the host Member State during their period of residence" 126 .

Making the residence right conditional upon the requirement of having a comprehensive medical insurance and sufficient recourses not to become a burden on the social assistance system of a host Member State, suggests that only those non-economic migrant Union citizens who are both medically insured and financially self-sufficient can base their lawful residence in another MS. In other words, only those EU migrants who represent virtually no threat to the host MS' public finances, will be admitted to its territory for a period longer then three months. This clearly indicates that what we are encountering here is another set of examples of defense mechanisms, aiming to ensure that migration of non-economically active Union citizens comes at no expense for the host MS' public purses. ${ }^{127}$

125 Article 7(1)(b) of Directive 2004/38. Emphasis added. In relation to the "comprehensive sickness insurance" requirement, the Commission has asserted that "any insurance cover, private or public, contracted in the host Member State or elsewhere, is acceptable in principle, as long as it provides comprehensive coverage and does not create a burden on the public finances of the host Member State". Commission (EC), 'Communication from the Commission to the European Parliament and the Council on guidance for better transposition and application of Directive 2004/38/EC on the right of citizens of the Union and their family members to move and reside freely within the territory of the Member States'

COM/2009/0313 final, 2 July 2009.

${ }_{126}$ Article 7(1) (c) of Directive 2004/38.

127 See further Derrick Wyatt and others, Wyatt and Dashwood's European Union Law (5th edn Sweet and Maxwell, London 2006), p. 666. The idea about introducing defense mechanisms intended to protect the MS' welfare schemes and public finances has been present since the earliest stages of development of legislation concerning the "general" right to residence in the EU. As O'Leary has elaborately described it, the debate about these legislative developments has from the very beginning reflected the 
However, this provision also reveals a distinction that the Union legislator makes between the two categories of non-economic migrant EU citizens, by prescribing different conditions of the residence right for each category. On the one hand, we can distinguish the category of economically independent citizens, which includes pensioners and self-sufficient persons, previously covered by Directives 90/364/EEC and 90/365/EEC. ${ }^{128}$ On the other hand, there is the category that comprises students, previously covered by Directive 93/96/EEC. 129

The main difference between the conditions for acquiring lawful residence imposed on the two categories concerns the "sufficient resources" requirement. While economically independent citizens actually have to provide evidence of their financial situation, students merely need to assure the relevant national authorities - by means of a declaration or by such equivalent means as they may choose - that they have sufficient resources not to become a burden on the social assistance system of a host Member State. ${ }^{130}$ It follows that, while the right to lawful residence is restricted in both cases, EU law requires a lower level of scrutiny when it comes to students.

worry that the unrestricted entry and residence of MS nationals in other MS would lead to considerable financial difficulties for some MS, in particular those that offered more generous welfare benefits. Thus, a number of MS have requested that the legislation in question should contain certain economic safeguards aiming to insure a sufficient degree of protection of the MS' welfare systems. In view of these concerns, the Commission has already in its first proposal of the Directive on residence, emphasized the importance of not burdening social security schemes of the receiving MS and has inserted the requested economic safeguards (namely, the "sufficient resources" requirement). Without any doubt, the same concerns also lay behind the insistence that, besides satisfying the "sufficient resources" requirement, the claimants of the residence right should have a comprehensive medical insurance covering all risks in the host MS. Síofra O'Leary, The Evolving Concept of Community Citizenship: From the Free Movement of Persons to Union Citizenship (Kluwer, The Hague 1996), pp. 110-112, 122.

128 See Derrick Wyatt and others, Wyatt and Dashwood's European Union Law (5th edn Sweet and Maxwell, London 2006), p. 679. This category is covered by Article 7(1)(b) of Directive 2004/38.

${ }^{129}$ See Derrick Wyatt and others, Wyatt and Dashwood's European Union Law (5th edn Sweet and Maxwell, London 2006), p. 680. This category is covered by Article 7(1)(c) of Directive 2004/38.

${ }^{130}$ Ibid.. In addition, the Court's case law clarifies that the truthfulness of a student's declaration is to be assessed only as at the time when it is made. Case C-184/99 Grzelczyk [2001] ECR I-6193, para 45. 
The Commission has identified and the Court has approved of several reasons for this distinction. ${ }^{131}$ The first one concerns the temporary character of a student's stay in a host MS. In particular, the Court has found that since a student's stay is limited to the duration of studies, the risk of him or her becoming a burden on social assistance system is less serious than in the case of economically independent citizens. ${ }^{132}$ The second reason for this distinction concerns the unpredictable character of a student's employment. The Court has found that, while it is easier for students than for pensioners and self-sufficient persons to supplement resources by income from part-time or periodic work, it is very difficult for them to produce any proof in advance that they will supplement their resources with income from such work. ${ }^{133}$ In addition to the listed reasons, one may think of another reason for this distinction, namely, the long-term dedication of the European Union to promoting student mobility. ${ }^{134}$ It that sense, one could argue that imposing less rigorous residence requirements on students makes sense in view of the Union's goal to promote student mobility and to encourage students to pursue their studies abroad.

Yet, the fact that a less stringent residence requirement applies to students does not suggest that reliance of a student on social security benefits of a host MS can have no negative consequences on the retention of his or her residence right. On the contrary, just as in the case of temporary residents and economically independent citizens, excessive reliance on the host MS' welfare system might transform a student into an "unreasonable burden" and, consequently, entitle a host MS to terminate his or her residence in accordance with Article 14(2) of the Citizens' Rights Directive. ${ }^{135}$

\footnotetext{
131 See the case C-424/98 Commission of the European Communities v Italian Republic [2000] ECR I-04001, paras 40, 45, cited in Grzelczyk case, para 41.

132 Ibid.

133 Ibid.

134 See Article 165(2) of the TFEU.

135 Derrick Wyatt and others, Wyatt and Dashwood's European Union Law (5th edn Sweet and Maxwell, London 2006), p. 680-1. In relation to this requirement, the Court has never considered whether, looked at cumulatively, a number of individuals relying on a host MS welfare system might constitute an "unreasonable burden" on its public finance. Instead, the Court has always focused on individual cases before it. See further Michael Dougan and Eleanor Spaventa, 'Educating Rudy and the (Non-)

English Patient: A Double Bill on Residency Rights under Article 18 EC’ (2003) 28(5) E.L. Rev. 699, p. 707.
} 
The final type of lawful residence right is the "right of permanent residence", provided for in Article 16 of the Citizens' Rights Directive. The main condition existing in relation to the permanent residence right is the requirement of 5 years of continuous lawful residence in the territory of a host MS. ${ }^{136}$ In its recent case law, the CJEU found the requirement of legal residence in Article 16(1) of Directive 2004/38 to mean a period of residence which complies with the conditions laid down in this directive, in particular those set out in Article 7(1). ${ }^{137}$ This means that a Union citizen who has been resident for more than five years in the territory of the host Member State on the sole basis of the national law of that Member State cannot be regarded as having acquired the right of permanent residence under Article 16(1) of Directive 2004/38 if, during that period of residence, he/she did not satisfy the conditions laid down in Article 7(1) of the Directive. ${ }^{138}$

In relation to the 5 years of continuous lawful residence requirement, Directive 2004/38 further clarifies that temporary absences not exceeding a total of six months a year, or longer absences in relation to compulsory military service, will not affect the required continuity of residence. ${ }^{139}$ It also provides that the continuity of residence will not be affected by an absence of a maximum of twelve consecutive months if this absence is caused by important reasons such as pregnancy and childbirth, serious illness, study or vocational training, or a posting in another Member State or a third country. ${ }^{140}$ However, the right of permanent residence will end in the case of an absence from a host

\footnotetext{
136 Article 16(1) of Directive 2004/38. Emphasis added. In this respect, the Court has clarified that continuous periods of five years' residence completed before the date of transposition of Directive 2004/38 must be taken into account for the purposes of the acquisition of the right of permanent residence pursuant to Article 16(1). Case C162/09 Lassal [2010] ECR I-09217, para 59.

${ }^{137}$ Joined Cases C-424/10 and C-425/10 Ziolkowski and Szeja [2011] ECR I-0000, para 46.

138 Ibid., para 51. The Court further clarified that that "periods of residence completed by a national of a non-Member State in the territory of a Member State before the accession of the non-Member State to the European Union must, in the absence of specific provisions in the Act of Accession, be taken into account for the purpose of the acquisition of the right of permanent residence under Article 16(1) of Directive $2004 / 38$, provided those periods were completed in compliance with the conditions laid down in Article 7(1) of the directive”. Ibid., para 63.

139 Article 16(3) of Directive 2004/38.

140 Ibid.
} 
Member State for a period exceeding two consecutive years. ${ }^{141}$

What is important to notice is that, once acquired, the right of permanent residence is not conditioned upon any economic or other requirements aiming to protect the MS' welfare schemes from potential financial burdens. On the contrary, after five years of continuous lawful residence, a migrant EU citizen is deemed to have established a sufficient link with the society of a host MS and has a full right to equal treatment in access to social benefits. ${ }^{142}$

It thus follows from the above analysis that the number of defense mechanisms decreases as the degree of integration of migrant EU citizens into a host MS's society grows. Bearing in mind the fact that the lawful residence requirement constitutes an important element in the equation describing the 'general rule' regarding access to equal treatment of noneconomic migrants, this finding seems to shed light on the policy choices of the EU legislator. Namely, by making access to equal treatment conditional upon the lawful residence requirement, and, furthermore, by proscribing less stringent requirements regarding the retention of the residence right in the case of long-term residents, the EU legislator seems to have opted for what we may call a "quantitative approach to equality" 143 . Accordingly, the longer the Union citizens stay in their host MS's territory, the bigger the chances are that they will be able to retain the status of lawful residents and, therefore, be treated equally with a host MS' nationals in access to social benefits.

\footnotetext{
${ }^{141}$ Article 16(4) of Directive 2004/38. In this regard, the Court has clarified that absences from the host Member State of less than two consecutive years, which occurred before the date of transposition of Directive 2004/38 but following a continuous period of five years' legal residence completed before that date do not affect the acquisition of the right of permanent residence pursuant to Article 16(1). Case C-162/09 Lassal [2010] ECR I-09217, para 59.

142 Derrick Wyatt and others, Wyatt and Dashwood's European Union Law (5th edn Sweet and Maxwell, London 2006), p. 684. Also see Koen Lenaerts, 'European Union Citizenship, National Welfare Systems and Social Solidarity' (2011) 18(2)

Jurisprudence 397, p. 409.

143 The term is borrowed from Catherine Barnard, who uses it in the context of defense mechanisms that exist in relation to the equal treatment requirement. She also refers to that approach as "an incremental approach to residence and equality", and in that sense argues that at the heart of the citizenship provisions "lies the basic idea that the rights enjoyed by the migrant citizen and their family members increase the longer a person is resident". Catherine Barnard, The Substantive Law of the EU: the Four Freedoms (2nd edn, OUP, Oxford 2007), pp. 416, 437-9.
} 
One can think of at least three reasons to justify this approach. The first one has to do with a sense of solidarity due to proximity, the second one with a lack of risk due to rarity and the third one with a growth of credibility due to continuity. More precisely, one possibility is that when adopting the "quantitative approach to equality" the EU legislator proceeded from the assumption that five years of lawful residence in a host MS' society suffice to generate a substantial degree of financial solidarity on part of the host MS. Accordingly, after this period, a host MS would regard a migrant EU citizen almost as one of its own nationals and would, therefore, be willing to allow him or her full access to its social benefits. ${ }^{144}$

Alternatively, the "quantitative approach to equality" might be based on the fact that a number of non-economic EU migrants who can satisfy the "five years of continuous lawful residence' requirement is so small that, in any event, they hardly represent a genuine threat to the host MS' public finance.

The final reason laying behind this approach might be grounded in the belief that a lawful resident's credibility comes from a continuous satisfaction of the residence requirements, making it highly unlikely for a lawful resident to stop fulfilling those requirements in the future. In other words, the "quantitative approach to equality" might be based on a belief that a continuous good record makes a lawful resident sufficiently trustworthy to remove all restrictions on his/her residence right after a certain period of time.

Whichever is the real reason laying behind the EU legislator's approach, the Union's regulatory power does not stop at merely defining the defense mechanisms left at the MS' disposal. It also plays an important role in defining the ways in which the MS can act when employing these defense mechanisms provided by EU law. The next section, therefore, analyzes the limitations imposed on the MS in the exercise of their discretion in the field of social policy when resorting to the defense mechanisms described above.

\footnotetext{
144 See Derrick Wyatt and others, Wyatt and Dashwood's European Union Law (5th edn Sweet and Maxwell, London 2006), p. 684. Similarly, Dougan and Spaventa speak of the nexus of "belonging" between a guest citizen and a host state, which becomes stronger as the time goes by. See Michael Dougan and Eleanor Spaventa, 'Educating Rudy and the (Non-) English Patient: A Double Bill on Residency Rights under Article 18 EC' (2003) 28(5) E.L. Rev. 699, p. 712.
} 
2.2.2.2 Limitations of the defense mechanisms related to the lawful residence requirement

As shown above, EU law provides the MS with a number of defense mechanisms in relation to the acquisition and retention of the right to temporary residence, as well as the right to residence for more than three months. ${ }^{145}$ However, EU law also imposes certain limitations in the application of these mechanisms.

The first set of limitations can be found in Article 8(4) of the Citizens' Rights Directive, in relation to the 'sufficient resources' requirement. According to this provision, the Member States are prohibited from lying down, either directly or indirectly, a fixed amount that they regard as "sufficient resources" and below which the right to residence can be automatically refused.146 Instead, in assessing whether a person concerned has sufficient resources, the MS have to take into account his or her personal situation. ${ }^{147}$ The first step in making this assessment is, according to the Commission, an inquiry into whether the EU citizen meets the national criteria to be granted the basic

${ }^{145}$ It should be added here that the listed conditions and limitations of the residence right are not the only restrictions available at the MS' disposal. In addition, EU law provides for the possibility of restricting the right of entry and residence on grounds of public policy, public security and public health (see Article 27 of Directive 2004/38). However, unlike the previously analyzed limitations and conditions, these restrictions cannot be classified as defense mechanisms intended to protect the MS' public finances from unreasonable burdens from abroad. This follows from the fact that EU law explicitly prescribes that these grounds can never be invoked to serve economic ends, which is precisely what the previously described defense mechanisms aim to do. Thus, these restrictions of the residence right and the limitations in their application will not constitute a part of the analysis undertaken in this chapter. ${ }^{146}$ Commission (EC), 'Communication from the Commission to the European Parliament and the Council on guidance for better transposition and application of Directive 2004/38/EC on the right of citizens of the Union and their family members to move and reside freely within the territory of the Member States'

COM/2009/0313 final, 2 July 2009.

${ }^{147}$ Article 8(4) of Directive 2004/38. Some regard this as a proof that Directive $2004 / 38$ takes into account the requirement of reasonableness and proportionality (which will be discussed below in more detail). See Massimo Condinanzi, Alessandra Lang and Bruno Nascimbene, Citizenship of the Union and Freedom of Movement of Persons (Martinus Nijhoff Publishers, Leiden 2008), p. 33. 
social assistance benefit. ${ }^{148}$ This follows from the EU law requirement that the amount regarded as "sufficient resources" cannot be higher than the threshold below which nationals of the host Member State become eligible for social assistance, or higher than the minimum social security pension paid by the host Member State. ${ }^{149}$ In relation to this requirement, EU law also prescribes that the MS cannot limit the means of proof of sufficient resources. ${ }^{150}$

In addition, it has been established that, for the purpose of assessment of "sufficient resources", it is not relevant who provides a Union citizen with resources, as long as he or she has access to them. ${ }^{151}$ In particular, the CJEU has clarified that regardless of whether the resources are supplied by a family member or even a third party, they have to be taken into account as if they were a Union citizen's own resources. 152

By imposing the requirements described above, EU law clearly restrains the MS' discretion in applying the 'sufficient resources' requirement and, consequently, limits the scope and the effect of this defense mechanism.

The second example of a limitation in the application of the defense mechanisms can be found in relation to the retention of the residence right in Article 14(3) of the Citizens' Rights Directive. This Article provides that an expulsion measure shall not be the automatic consequence of a Union citizen's or his or her family member's recourse to the social assistance system of the host Member State. ${ }^{153}$ This provision, which further limits the host

${ }^{148}$ Commission (EC), 'Communication from the Commission to the European Parliament and the Council on guidance for better transposition and application of Directive 2004/38/EC on the right of citizens of the Union and their family members to move and reside freely within the territory of the Member States'

COM/2009/0313 final, 2 July 2009. In this Communication, the Commission further clarifies that "the resources do not have to be periodic and can be in the form of accumulated capital".

${ }^{149}$ Article 8(4) of Directive 2004/38.

${ }^{150}$ Case C-424/98 Commission v Italy [2000] ECR I-04001, para 37.

151 See further Derrick Wyatt and others, Wyatt and Dashwood's European Union Law (5th edn Sweet and Maxwell, London 2006), p. 679.

152 Ibid., citing case C-200/02 Chen [2004] ECR I-09925 C-408/03 and case C408/03 Commission of the European Communities v Kingdom of Belgium [2006] ECR I02647 .

153 Article 14(3) of Directive 2004/38. 
MS's discretion in assessing who represents a burden on its social assistance scheme, is a codification of the Court's ruling in the Grzelczyk case.

As previously described, this case concerned a French student studying in Belgium, from whom the payment of a non-contributory benefit, minimex, was withdrawn on the ground that he was neither a Belgian national, nor a worker. Mr. Grzelczyk applied for the benefit in question in the last year of his studies in Belgium, when, due to the increased workload, he was no longer in a position to finance his studies by taking on various minor jobs. ${ }^{154}$

In assessing whether a person such as Mr. Grzelczyk can rely on the Article 18 anti-discrimination guarantee to challenge the decision of the national authorities, the Court observed that a host MS can take the view that a student having recourse to its social assistance no longer fulfills the conditions of his or her residence right. ${ }^{155}$ Accordingly, a host MS is entitled to take measures, within the limits imposed by EU law, either to withdraw a student's residence permit or not to renew it. ${ }^{156}$

However, the Court has also emphasized that expulsion measures can in no case become the automatic consequence of the fact that a student, who is a national of another MS, has recourse to the host MS's social assistance system. ${ }^{157}$ This, in other words, means that it is impermissible for a host Member State to equate 'recourse to social assistance' with 'lack of sufficient resources' when deciding about the retention of a residence right of a noneconomic migrant EU citizen residing in its territory. ${ }^{158}$

\footnotetext{
${ }^{154}$ Case C-184/99 Grzelczyk [2001] ECR I-6193, paras 10, 11.

155 Ibid., para 42.

156 Ibid.

$157 \mathrm{Id}$, para 43. Emphasis added. In this respect, the Court has clearly followed the reasoning of Advocate General Alber who found that "even if the Member States remained empowered under Community law to condition the right of residence to the existence of sufficient resources of the student, the recourse to public funds could not automatically lead to the extinction of the student's right to stay in the host State”. See Catherine Jacqueson, 'Union citizenship and the Court of Justice: something new under the sun? Towards social citizenship' (2002) 27 E.L. Rev. 260, p. 275, citing paras 122-3 of the Opinion of Advocate General Alber in case C-184/99, Grzelczyk, [2001] ECR I-6193.

158 Gráinne de Búrca and Paul Craig, EU Law: Text, Cases and Materials (4th edn OUP, Oxford 2008), p. 861.
} 
This follows from the fact that EU law accepts a certain degree of financial solidarity between nationals of a host MS and nationals of other MS, which is, according to the Court, visible from the requirement that beneficiaries of the residence right must not become an unreasonable burden on the host MS' public finances ${ }^{159.160}$ The Court further asserted that such solidarity is particularly required in cases, such as the one at hand, where financial difficulties encountered by a beneficiary of the residence right are temporary in character. ${ }^{161}$

The requirement not to take expulsion measures as an automatic consequence of a resident's recourse to the social assistance system of a host MS was later confirmed in the case Trojani162 and subsequently codified in Art 14(3) of the Citizens' Rights Directive. Moreover, its meaning was further clarified in the Directive's Preamble. In particular, it was prescribed that "the host Member State should examine whether it is a case of temporary difficulties and take into account the duration of residence, the personal circumstances and the amount of aid granted in order to consider whether the beneficiary has become an unreasonable burden on its social assistance system and to proceed to his expulsion" 163 .

${ }^{159}$ At the time, this requirement was contained in the Preamble to Directive 93/96 (which was applicable in the Grzelczyk case), as well as Directives 90/364 and 90/365, all of which were replaced by Directive 2004/38. Emphasis added.

160 Case C-184/99 Grzelczyk [2001] ECR I-6193, para 44.

161 Ibid.. Some authors read this case as a 'hidden' application of the principle of proportionality to the requirement of "sufficient resources". See, for example, Michael Dougan and Eleanor Spaventa, 'Educating Rudy and the (Non-) English Patient: A Double Bill on Residency Rights under Article 18 EC' (2003) 28(5) E.L. Rev. 699, p. 703.

162 Case C-656/02 Trojani [2004] ECR I-7573, para 45.

${ }^{163}$ Recital 16 of Directive 2004/38. Based on this recital, the Commission has distinguished three main criteria to be considered before a host MS can take expulsion measures, namely, duration, personal situation and amount. Moreover, it has provided the MS with a detailed list of questions to be examined in relation to these criteria. The list goes as follows:

"(1) duration

- For how long is the benefit being granted?

- Outlook: is it likely that the EU citizen will get out of the safety net soon?

- How long has the residence lasted in the host Member State?

(2) personal situation

- What is the level of connection of the EU citizen and his/her family members with the society of the host Member State? 
This requirement imposed on the MS to show a degree of financial solidarity and take all individual circumstances into account prior to taking any expulsion measures, indicates that the MS are expected to carry a "reasonable burden" in relation to the exercise of freedom of movement of Union citizens. ${ }^{164}$ Some argued that this requirement significantly limits the MS' power to regulate immigration, since the host MS are not left much maneuvering space once a migrant Union citizen legally enters their territory. 165 It can be added that, given the existence of the 'general rule' on equal treatment of non-economic Union migrants described above, the MS' power to regulate their welfare systems is also limited as a direct implication of this requirement.

The final limitation of the defense mechanisms derives from the requirement that limitations and conditions of the residence right must be applied in accordance with the general principles of EU law, in particular the principle of proportionality. 166 This requirement, defined in the Baumbast case, means

- Are there any considerations pertaining to age, state of health, family and economic situation that need to be taken into account?

(3) amount

- Total amount of aid granted?

- Does the EU citizen have a history of relying heavily on social assistance?

- Does the EU citizen have a history of contributing to the financing of social assistance in the host Member State?".

Finally, the Commission has once again asserted that "as long as the beneficiaries of the right of residence do not become an unreasonable burden on the social assistance system of the host Member State, they cannot be expelled". Commission (EC), 'Communication from the Commission to the European Parliament and the Council on guidance for better transposition and application of Directive 2004/38/EC on the right of citizens of the Union and their family members to move and reside freely within the territory of the Member States' COM/2009/0313 final, 2 July 2009. ${ }^{164}$ Gráinne de Búrca and Paul Craig, EU Law: Text, Cases and Materials (4th edn OUP, Oxford 2008), p. 865. Also see Massimo Condinanzi, Alessandra Lang and Bruno Nascimbene, Citizenship of the Union and Freedom of Movement of Persons (Martinus Nijhoff Publishers, Leiden 2008), p. 32

165 Catherine Jacqueson, 'Union citizenship and the Court of Justice: something new under the sun? Towards social citizenship' (2002) 27 E.L. Rev. 260, p. 278, citing Sybilla Fries and Jo Shaw, 'Citizenship of the Union: First Steps in the European Court of Justice’ (1998) 4(4) Eur Pub L 544.

166 See case C-413/99 Baumbast [2002] ECR I-07091, para 91. This is also acknowledged in Article 52 of the Charter of Fundamental Rights of the European Union, Official Journal C 303 of 14 December 2007. 
that, while it is legitimate for the MS to impose certain limitations and conditions on beneficiaries of the residence right in order to avoid unreasonable burdens on their social assistance systems, the measures adopted must be necessary and appropriate to attain this legitimate aim. ${ }^{167}$ In other words, the Court has recognized that the limitations and conditions of the residence right are based on the idea that the exercise of lawful residence can be subordinated to the legitimate interests of the MS, namely that of protecting their public finances from unreasonable burdens from abroad. ${ }^{168}$ However, it has also asserted that whenever the MS apply these limitations and conditions, they have to act proportionately.

The Baumbast ruling was the first case in which the Court has tested whether the national measure applying the limitations and conditions of the residence right complies with the principle of proportionality. This case concerned Mr. Baumbast, a German national, who after five years of lawful residence in the UK, applied for indefinite leave to remain. The UK authorities refused to renew his residence permit on the ground that he was neither a worker, nor a person having a general right to reside, since he did not satisfy the conditions of the residence right prescribed by secondary EU legislation ${ }^{169}$. Specifically, the UK authorities found that Mr. Baumbast did not satisfy the 'comprehensive sickness insurance' requirement, since his sickness insurance in Germany did not cover the emergency treatment in the host MS. ${ }^{170}$

In applying the proportionality test to the case at hand, the Court found that in the circumstances where the beneficiary of the residence right has sufficient resources and a comprehensive sickness insurance that covers all but emergency treatment, where he has resided lawfully in the host MS for several years, and where neither he nor his family members have been a burden on the host MS public finance, the decision of the UK authorities amounts to a disproportionate interference with the exercise of the residence right. ${ }^{171}$

The fact that the Court has put the host MS' decision under such scrutiny, demonstrates that the principle of proportionality clearly limits the MS

\footnotetext{
167 Case C-413/99 Baumbast [2002] ECR I-07091, paras 90, 91.

168 Ibid.

${ }^{169}$ At the time, Directive 90/364. See case C-413/99 Baumbast [2002] ECR I-07091, para 21.

170 Ibid., paras 21, 93.

${ }^{171}$ Ibid., 92, 93.
} 
discretion in applying the defense mechanisms. Moreover, it demonstrates that the emphasis has shifted from whether a beneficiary of the residence right satisfies the 'sufficient resources' and the 'comprehensive sickness insurance' requirement, towards the question whether he or she constitutes an unreasonable burden on the public finances of the host MS.172

In that regard, Dougan and Spaventa have observed that the Baumbast ruling fosters the emergence of "new models of social solidarity"173. This follows from the fact that Union citizens now seem to be able enjoy the residence right even though they do not fully meet the requirements set out by the Union legislature. ${ }^{174}$ According to Dougan and Spaventa, the requirement of applying the principle of proportionality to the limitations and conditions contained in the Citizens' Rights Directive thus expands the legal content of Union citizenship by extending the benefits of free movement to categories of persons previously excluded. ${ }^{175}$

172 Michael Dougan and Eleanor Spaventa, 'Educating Rudy and the (Non-) English Patient: A Double Bill on Residency Rights under Article 18 EC' (2003) 28(5) E.L. Rev. 699, p. 699. This seems to be acknowledged by the Commission in the Commission (EC), 'Communication from the Commission to the European Parliament and the Council on guidance for better transposition and application of Directive 2004/38/EC on the right of citizens of the Union and their family members to move and reside freely within the territory of the Member States' COM/2009/0313 final, 2 July 2009. This document states that "the notion of 'sufficient resources' must be interpreted in the light of the objective of the Directive, which is to facilitate free movement, as long as beneficiaries of the right of residence do not become an unreasonable burden on the social assistance system of the host Member State".

${ }^{173}$ Michael Dougan and Eleanor Spaventa, 'Educating Rudy and the (Non-) English Patient: A Double Bill on Residency Rights under Article 18 EC’ (2003) 28(5) E.L. Rev. 699, pp. 699, 704.

${ }^{174}$ Michael Dougan, 'The constitutional dimension to the case law on Union citizenship' (2006) 31(5) E.L. Rev 613, p. 616. In particular, it was suggested that since the limitations and conditions of the right to residence must now be applied in accordance with the general principles of EU law, even those EU citizens who do not possess "completely sufficient resources and/or entirely comprehensive medical insurance can still enjoy rights of residency", and consequently of equal treatment. Michael Dougan and Eleanor Spaventa, 'Educating Rudy and the (Non-) English Patient: A Double Bill on Residency Rights under Article 18 EC' (2003) 28(5) E.L. Rev. 699, p. 700.

175 Michael Dougan and Eleanor Spaventa, 'Educating Rudy and the (Non-) English Patient: A Double Bill on Residency Rights under Article 18 EC’ (2003) 28(5) E.L. Rev. 699, p. 700. 
In particular, as a result of the application of the proportionality test, the limitations and conditions provided for in secondary EU legislation "stop acting like exhaustive conditions and become more like criteria", since the Member States are now required to take into account a number of individual circumstances when applying these restrictions. ${ }^{176}$ The requirement to comply with the principle of proportionality consequently "also challenges the traditional thresholds of belonging and exclusion established by the Member States as a means of regulating access to their welfare benefits" 177 . What seems to follow is that the application of the Baumbast rule has not only rendered the defense mechanisms offered by EU law less effective, but it has also substantially limited MS discretion in organizing their welfare systems.

In addition, some have suggested that the requirement of applying the limitations and conditions of the residence right in accordance with the

176 Ibid., pp. 705-706. Dougan and Spaventa add that this kind of approach, whereby EU secondary legislation is reinterpreted, or even effectively rewritten according to demands of primary EU law, is not without precedence. To support their argument, they list a number of cases where the Court has applied a similar methodology as the one applied in the Baumbast case (although here more radically), such as the case C158/96 Kohll [1998] ECR I-1935, case C-157/99 Smits and Peerbooms [2001] ECR I5473 and case C-459/99 MRAX [2002] ECR I-6591. In that regard, Dougan further argues that, as a result of the application of this methodology, the real losers of the recent citizenship case law are not the Member States, but rather the Union legislature itself. According to his argument, this is so due to the fact that the EU political institutions have "witnessed and appreciable decrease in their effective regulatory competence, to the extent that legislative choices are now being subject (albeit indirectly) to a level of judicial review based upon the principle of proportionality which does not usually apply to those activities”. Michael Dougan, 'The constitutional dimension to the case law on Union citizenship' (2006) 31(5) E.L. Rev 613, p. 640. While this argument may be regarded as correct in view of the effects of this methodology on the regulatory legislative competence, it does not seem to hold water in view of the financial consequences of these developments. From the financial perspective, the biggest losers seem to be the Member States, since they are the ones baring the costs of such developments. In other words, given the fact that the application of the proportionality test extends the possibility of access to social benefits to those categories of Union citizens who would otherwise be excluded from it, it is the MS' finances that suffer the most, since the MS they are the primary providers, not the Union. Thus, while the regulatory competence of the EU may be affected, it seems that it is the MS who suffer most damage in the end, because scrutinizing their actions in the light of the proportionally principle impacts directly on their financial interests.

177 Ibid., p. 701. 
general principles of EU law likely implies that the MS are not only supposed to comply with the principle of proportionality, but also with fundamental rights as general principles of EU law. ${ }^{178}$ If so, this will clearly amount to a further limitation of the MS regulatory powers in the area of social policy. ${ }^{179}$ It is worth noting that Baumbast is not the only case where the Court assessed whether particular national measures concerning limitations and conditions of the residence right comply with the principle of proportionality. Another example of the application of the proportionality test concerns the previously mentioned case law in which the Court found that the origin of financial resources is irrelevant for the purpose of assessing whether the 'sufficient resources' requirement is fulfilled. ${ }^{180}$ This case law specifies that a requirement as to the origin of the resources is not necessary for the attainment of the legitimate aim in question, that is, protecting a host MS's public finance from unreasonable burdens. ${ }^{181}$ Consequently, imposing such

178 See Ibid., p. 710-11 and Derrick Wyatt and others, Wyatt and Dashwood's European Union Law (5th edn Sweet and Maxwell, London 2006), p. 671. This seems to be acknowledged in the Commission (EC), 'Communication from the Commission to the European Parliament and the Council on guidance for better transposition and application of Directive 2004/38/EC on the right of citizens of the Union and their family members to move and reside freely within the territory of the Member States' COM/2009/0313 final, 2 July 2009. In this Communication the Commission recalled that the Directive 2004/38 "must be interpreted and applied in accordance with fundamental rights, in particular the right to respect for private and family life, the principle of non-discrimination, the rights of the child and the right to an effective remedy as guaranteed in the European Convention of Human Rights (ECHR) and as reflected in the EU Charter of Fundamental Rights”. Finally, Directive 2004/38 itself acknowledges that "it respects the fundamental rights and freedoms and observes the principles recognized in particular by the Charter of Fundamental Rights of the European Union”. Recital 31 of Directive 2004/38.

${ }^{179}$ According to Dougan and Spaventa, the right to family life might play an important role in this respect, since both the CJEU and the European Court of Human Rights ("ECtHR") "have held that the removal of a person from a country where close members of his/her family are living might infringe that person's right to family life". In that regard, a host MS's "ability to expel individuals who would otherwise be considered an unreasonable burden upon public purse" could be limited. Michael Dougan and Eleanor Spaventa, 'Educating Rudy and the (Non-) English Patient: A Double Bill on Residency Rights under Article 18 EC' (2003) 28(5) E.L. Rev. 699, pp. 710-11.

180 See above footnote $151,152$.

181 Case C-200/02 Chen [2004] ECR I-09925 C-408/03, paras 32-33 and case C408/03 Commission of the European Communities v Kingdom of Belgium [2006] ECR I02647, paras 39-51. 
additional requirements on beneficiaries of the residence right, according to the Court, amounts to a disproportionate interference with the exercise of the fundamental right of freedom of movement and residence provided for by Article 21 of the TFEU. 182

Taken together, all of the mentioned requirements limiting MS' discretion in applying the defense mechanisms suggest that what was given by one hand was (at least to a certain extent) taken away by the other. Having in mind the relevant legal developments, one might wonder if the defense mechanisms still deserve to be called that way and are the MS, after all, really capable of defending their social security schemes from unreasonable financial burdens from abroad.

Before answering these questions, however, two additional elements of the 'general rule' on equal treatment of non-economic EU migrants need to be assessed. It remains to be seen how the Court has interpreted the 'scope ratione materiae of EU law', and whether any defense mechanisms are left at the MS' disposal in relation to the equal treatment guarantee. This will be analyzed in the following sections.

\subsubsection{The 'scope ratione materiae of EU law' requirement}

According to the 'general rule' described above, all migrant Union citizens lawfully resident in the territory of a host MS have the right to be treated equally in situations falling within the scope ratione materiae of EU law. It follows that if a non-economic migrant EU citizen seeks to claim equal treatment in access to certain benefits on the same terms as the host MS's nationals, his or her situation and, in particular, the sought object of financial support must be covered by the Union law. ${ }^{183}$ As previously mentioned, the Court has clarified that situations falling within the scope ratione materiae of EU law include those involving the exercise of fundamental freedoms, as well as those involving the exercise of the right to move and reside freely in the territory of another Member State. ${ }^{184}$

\footnotetext{
182 Ibid.

183 See para 9 of the Opinion of Advocate General in the case Bidar C-209/03 [2005] ECR I-2119.

${ }^{184}$ Case C-184/99 Grzelczyk [2001] ECR I-6193, paras 32-33.
} 
The question that remains to be answered is which situations and, more importantly, according to which criteria should be classified as falling within the material scope of the Treaty for our purposes. In this context, it is crucial to analyze the CJEU's case law dealing with equal treatment in access to social benefits of non-economic migrant EU citizens living in other MS. This case law reveals that, so far, thanks to the generous interpretation adopted by the Court, several kinds of social and educational benefits have been classified as falling within the material scope of EU law, in situations concerning noneconomic migrant Union citizens.

In its Martinez Sala judgment, the Court reached the conclusion that a noncontributory benefit, such as a child-raising allowance, falls within the material scope of EU law, based on the fact that it constitutes a social advantage within the meaning of Regulation 1612/68 and a family benefit within the meaning of Regulation 1408/71. ${ }^{185}$ In the following case Grzelczyk, the Court relied on its earlier case law 186 and a more comprehensive line of reasoning to conclude that a non-contributory social benefit such as a minimum subsistence allowance (the so-called minimex) also falls within the Treaty scope. In that regard, the Court clarified that situations falling within the scope ratione materiae of EU law include those involving the exercise of the right to move and reside freely in another Member State. ${ }^{187}$ The Court's finding in Grzelczyk was subsequently confirmed in the Trojani case. ${ }^{188}$ In the cases Bidar and Förster, the Court reached the conclusion that maintenance student assistance also constitutes a benefit covered by the scope ratione materiae of EU law. 189 Finally, in its recent decision Commission v Austria, the Court found that reduced transport fares for students come within the scope of the Treaty in so far as they enable them, directly or indirectly, to cover their maintenance costs. ${ }^{190}$

\footnotetext{
185 Case C-85/96 Martínez Sala [1998] ECR I-2691, paras 26-27.

186 According to which a benefit in question - a minimum subsistence allowance constitutes a social advantage within the meaning of Regulation 1612/68. See case C184/99 Grzelczyk [2001] ECR I-6193, para 27. Also see para 24 of the Opinion of Advocate General in the case Bidar C-209/03 [2005] ECR I-2119.

187 Case C-184/99 Grzelczyk [2001] ECR I-6193, paras 32-33.

188 Case C-456/02 Trojani [2004] ECR I-7573, para 42.

${ }^{189}$ Case C-209/03 Bidar [2005] ECR I-2119, paras 37-48 and case C-158/07 Förster [2008] ECR 00000.

190 Case C-75/11 Commission v Austria [2012] ECR 00000, para 43. However, the Court also clarified that such transport costs for students do not come within the derogation from the principle of equal treatment provided for in Article 24(2) of
} 
It should be noted that in reaching those decisions, the Court often significantly departed from its settled case law, thereby bringing within the Treaty's scope certain benefits previously excluded.

The first example of such change in the Court's approach can be detected in Martinez Sala. In this case, the Court found that a child-raising allowance falls within the material scope of the Treaty, solely by virtue of the fact that it is covered by Regulation 1612/68 and Regulation 1408/71, and "irrespective of the status of the person claiming the benefit" 191 . This conclusion was reached regardless the fact that it was yet to be determined by the national court whether Mrs. Martínez Sala fell within the category of persons to whom these Regulations apply. Moreover, it was reached even though the Court's judgment was premised on the fact that Mrs. Martínez Sala does not constitute a worker. ${ }^{192}$

The Court has thus departed from its earlier case law ${ }^{193}$, where it had carefully analyzed the actual fulfillment of conditions for the application of these Regulations in deciding whether a particular situation falls within the material scope of EU law. ${ }^{194}$ Consequently, the Court has also expanded the access to this particular benefit to persons previously excluded from it.

As mentioned before, the Court has elaborated and somewhat modified this approach in the case Grzelczyk. Unlike in Martinez Sala, in Grzelczyk the Court did not define the material scope of EU law purely by reference to the

Directive 2004/38. According to the Court, this derogation from the principle of equal treatment provided for in Article 18 TFEU requires a narrow interpretation, which, more concretely, means that only maintenance aid for studies 'consisting in student grants or student loans' come within its scope. Ibid., paras 54, 55.

191 Catherine Jacqueson, 'Union citizenship and the Court of Justice: something new under the sun? Towards social citizenship' (2002) 27 E.L. Rev. 260, p. 266. For the comment, see further Sybilla Fries and Jo Shaw, 'Citizenship of the Union: First Steps in the European Court of Justice' (1998) 4(4) Eur Pub L 544, p. 543.

192 See Catherine Barnard, The Substantive Law of the EU: the Four Freedoms $\left(2^{\text {nd }}\right.$ edn, OUP, Oxford 2007), p. 432.

193 Namely, the case 316/85 Lebon [1987] ECR 02811.

194 Catherine Jacqueson, 'Union citizenship and the Court of Justice: something new under the sun? Towards social citizenship' (2002) 27 E.L. Rev. 260, p. 265, citing the case 316/85 Lebon [1987] ECR 02811. Also see Sybilla Fries and Jo Shaw, 'Citizenship of the Union: First Steps in the European Court of Justice' (1998) 4(4) Eur Pub L 544, pp. 551-553. 
fact that the benefit in question is covered by one of the mentioned Regulations. Rather, it defined it by reference to the fact that the situation in question involves the exercise of the right to move and reside freely across the Union. 195

Based on this, the Court has found that assistance given to a student for maintenance and studies in the form of a non-contributory social benefit minimex falls within the substantive Treaty scope. ${ }^{196}$ In that, it departed from its earlier case law where it has held that assistance given to students for maintenance and training falls, in principle, outside the scope of the Treaty for the purposes of Article 18197, since it is, on the one hand, a matter of educational policy which is not as such covered by EU law and, on the other hand, a matter of social policy which falls within the competence of the Member States in so far as it is not covered by the Treaty. 198

The Court acknowledged the fact that its past decisions differ from the present one. It justified its novel reasoning with the fact that new developments have taken place in EU law since the time its earlier decisions were decided. In particular, the Court argued that since then "the Treaty on European Union has introduced citizenship of the European Union into the EC Treaty and added to Title VIII of Part Three a new chapter 3 devoted to education and vocational training" 199 . In addition, the Court asserted that "the Council has [...] adopted Directive 93/96, which provides that the Member States must grant right of residence to student nationals of a Member State who satisfy certain requirements" 200 .

The question was raised, however, whether the justifications offered by the Court are convincing and whether the mentioned developments truly brought about substantial change as regards maintenance grants for foreign

\footnotetext{
195 See Catherine Barnard, The Substantive Law of the EU: the Four Freedoms ( $2^{\text {nd }}$ edn, OUP, Oxford 2007), p. 433.

196 Case C-184/99 Grzelczyk [2001] ECR I-6193, paras 33-35.

197 Originally, Article 7 of the EEC Treaty.

198 Case 197/86 Brown [1988] ECR 03205, para 18 and case 39/86 Lair [1988] ECR

03161, para 15. In these cases, the Court has pointed out that student assistance falls within the scope of EU law only in so far as it is intended to cover registration and other fees, in particular tuition fees, charged for access to education. See Lair, para 16 and Brown, para 17.

199 Case C-184/99 Grzelczyk [2001] ECR I-6193, para 35.

${ }^{200}$ Ibid.
} 
students. ${ }^{201}$ In answering this question, Jacqueson has rightly argued that the only substantial change that occurred in this context was the introduction of the concept of EU citizenship, since it enhanced the equality guarantees provided to Union citizens. ${ }^{202}$ The Court's decision to include minimex within the substantive Treaty scope is thus justified, since entering of the concept of Union citizenship on the scene implied a considerable expansion of the scope of EU law. Invoking this particular novelty to justify the change in the Court's approach, therefore, seems legitimate and convincing.

However, apart from the introduction of Union citizenship, none of the other justifications invoked by the Court seem very persuasive. This follows from the fact that neither the new Chapter 3 nor Directive 93/96 can be considered as an important change towards more integration in the area of educational or social policy.203 On the contrary, these EU law provisions should rather be seen as a reassertion of the MS' power and control in these areas. ${ }^{204}$

These arguments, or better to say criticisms of the Court's reasoning, are based on the fact that Chapter 3 of the Maastricht Treaty only provides that the EU shall contribute to the development of quality of education by encouraging cooperation between the Member States and implement a vocational training policy, while fully respecting the MS' sovereignty in the area of education and vocational training. ${ }^{205}$ In addition, it was rightly marked that this Chapter excludes the possibility of any harmonization in these areas. ${ }^{206}$

\footnotetext{
201 See Catherine Jacqueson, 'Union citizenship and the Court of Justice: something new under the sun? Towards social citizenship' (2002) 27 E.L. Rev. 260, p. 270. 202 Ibid. p., 273.

${ }^{203}$ Ibid., p. 272. For even stronger criticism of the Court's approach see Kay Hailbronner, 'Union Citizenship and Access to Social Benefits' (2005) 42 CML Rev. 1245 , p. 1250.

${ }^{204}$ Catherine Jacqueson, 'Union citizenship and the Court of Justice: something new under the sun? Towards social citizenship' (2002) 27 E.L. Rev. 260, p. 272, citing Jo Shaw, 'From the margins to the centre: education and training law and policy', in Gráinne de Búrca and Paul Craig, The Evolution of EU Law (OUP, Oxford 1999), p. 572.

205 Ibid.. See Article 126 and 127 of the Treaty on European Union (Treaty on Maastricht), Official Journal C 191 of 29 July 1992.

${ }^{206}$ See Ibid.
} 
Accordingly, it seems to follow that Chapter 3 is inserted not to expand, but to limit the Union powers by asserting that the Member States still hold control of these matters and that intrusions by the EU will not be tolerated.207 As far as Directive 93/96 is concerned, it was correctly noted that while it grants the residence right to students under certain conditions, it explicitly states that it does not establish any entitlement of students to maintenance grants. ${ }^{208}$

By revealing that neither Chapter 3 of the Maastricht Treaty, nor Directive 93/96 provide any substantial proof that the areas of educational and social policy have been transferred into the realm of EU competence, these arguments have demonstrated that the Court's reasoning justifying the departure from its previous case law is not entirely convincing. ${ }^{209}$

In Bidar, the Court has resorted to an equally unpersuasive reasoning to justify the assertion that maintenance aid given to students in the form of grants and loans now falls within the scope of the Treaty. ${ }^{210}$ In particular, the Court has once again affirmed that recent developments, that is, the introduction of Union citizenship and the expansion of the Treaty to cover education policy, justify the departure from its earlier case law. ${ }^{211}$ Yet, unlike in Grzelczyk, the Court excluded the argument based on Directive 93/96 and supplemented its reasoning by invoking Article 24(2) of Directive 2004/38. It stated that the fact that this provision restricts the grant of maintenance aid in the form of grants and loans to those students who have acquired the right of permanent residence (unless they constitute workers, self-employed persons, persons who retain such status or members of their families), confirms that the Union legislature took the view that these benefits indeed fall within the

\footnotetext{
${ }^{207}$ Catherine Jacqueson, 'Union citizenship and the Court of Justice: something new under the sun? Towards social citizenship’ (2002) 27 E.L. Rev. 260, p. 272.

${ }^{208}$ Ibid., p. 273. See Article 3 of the Council Directive (EEC) 93/96 on the right of residence for students [1993] OJ L 317/0059.

${ }^{209}$ See further Catherine Jacqueson, 'Union citizenship and the Court of Justice:

something new under the sun? Towards social citizenship' (2002) 27 E.L. Rev. 260, pp. 270-273. Also see Síofra O'Leary, 'Equal treatment and EU citizens: A new chapter on cross-border educational mobility and access to student financial assistance' (2009) 34(4) E.L. Rev. 612, p. 614.

210 Case C-209/03 Bidar [2005] ECR I-2119, paras 37-48.

211 Ibid., paras 38-42.
} 
scope ratione materiae of the Treaty. ${ }^{212}$

It is interesting to note that, at the time the circumstances of this case took place, Directive 2004/38 had not yet entered into force, nor had the transposition period expired at the time the judgment was delivered. In other words, Directive 93/96 and its Article 3 were still applicable to this case. Yet, the Court decided to justify its novel reasoning by relying on Article 24(2) of the new Citizens' Rights Directive. In this regard, it might again be argued that the Court has resorted to a somewhat dubious reasoning in justifying its approach, whereby it further expanded the scope of EU law.

All in all, the analysis of the Court's reasoning relating to the scope ratione materiae of EU law seems to demonstrate that, in the context of cases dealing with equal treatment in access to social benefits of non-economic EU migrants, the Court has frequently resorted to a "pro-integrative approach"213. In this way, it extended the material Treaty scope so as to enable access to social benefits to those categories of persons who were previously kept out of it. By doing so, the Court seemed to have engaged in a hidden balancing 214 between the conflicting goals of promoting the freedom of movement and social solidarity, and that of safeguarding national welfare systems. As the end result of this process, the balance was clearly tipped in favor of protecting the free movement rights of Union citizens and promoting solidarity between host MS and EU migrants inhabiting them.

The analysis of this element of the 'general rule' thus seems to lead to the conclusion that by relying on the concept of EU citizenship and the developments surrounding it, the Court has played in favor of an expansion of the Union citizens' rights and against the preservation of MS' exclusive powers in the social policy field.

\footnotetext{
212 Ibid., para 43. Also see Síofra O'Leary, 'Equal treatment and EU citizens: A new chapter on cross-border educational mobility and access to student financial assistance' (2009) 34(4) E.L. Rev. 612, pp. 614-615.

213 The term is borrowed from Catherine Jacqueson, 'Union citizenship and the Court of Justice: something new under the sun? Towards social citizenship' (2002) 27 E.L. Rev. 260, p. 273.

214 The notion of a covert or hidden balancing is borrowed from Paul Davies, 'Market Integration and Social Policy in the Court of Justice' (1995) 49 ILJ 49, p. 67.
} 


\subsubsection{The equal treatment guarantee}

The 'general rule' on equal treatment of non-economic migrant EU citizens lawfully residing in a MS other then that of their origin provides that they will be treated on the same terms as the host MS nationals in access to social and other benefits, if their situation falls within the material Treaty scope. This rule, established and repeatedly acknowledged in the described Court's case law, was also inserted in Article 24 of Directive 2004/38. Accordingly, Article 24(1) of the Citizens' Rights Directive now provides that "all Union citizens residing on the basis of this Directive in the territory of the host Member State shall enjoy equal treatment with the nationals of that Member State within the scope of the Treaty".

The question that remains to be answered is what exactly the equal treatment guarantee implies. Are there any situations in which the MS can lawfully deny it, even though all of the preceding elements of the equation summarizing the 'general rule' have been satisfied? In other words, it remains to be seen whether EU law provides the MS with any defense mechanisms in relation to the equal treatment requirement. If so, what are the limitations in their application?

First, regarding the precise meaning of the principle of equal treatment, it should be noted that along with the so-called direct or overt discrimination on grounds of nationality, EU law also prohibits all forms of indirect or covert discrimination which, by applying other distinguishing criteria, lead in fact to the same result. ${ }^{215}$ However, this right of migrant Union citizens who reside in a host MS not to be directly or indirectly discriminated on grounds of nationality is not guaranteed in absolute terms. It can be subject to certain exceptions, which is recognized in Article 24 of Directive 2004/38. This means that, as a derogation from the 'general rule' stated above, EU law allows certain situations in which unequal treatment of Union citizens will be regarded as permissible or justified. In that way, EU law virtually provides the MS with new forms of defense mechanisms for 'escaping' the rule that could otherwise have negative impacts on controlling and financing of their welfare systems.

\footnotetext{
215 See, for example, case C-209/03 Bidar [2005] ECR I-2119, para 51, citing cases 152/73 Sotgiu [1974] ECR 153, para 11; C-57/96 Meints [1997] ECR I-6689, para 44 and C-212/99 Commission v Italy [2001] ECR I-4923, para 24. See further Anne Pieter van der Mei, Free Movement of Persons within the European Community: CrossBorder Access to Public Benefits (Hart Publishing, Oxford 2003), pp. 74-77.
} 
Two exceptions to the equal treatment guarantee are immediately apparent from Article 24(2) of Directive 2004/38. First, Article 24(2) provides that host Member States are not obliged to confer entitlement to social assistance during the first three months of residence, or longer in case of jobseekers. Second, Article 24(2) provides that host Member States are not obliged, "prior to acquisition of the right of permanent residence, to grant maintenance aid for studies, including vocational training, consisting in student grants or student loans to persons other than workers, self-employed persons, persons who retain such status and members of their families". This later derogation of the equal treatment guarantee, in turn, seems to represent an equivalent of the 'genuine link' requirement, an important defense mechanism established by the Court in cases concerning jobseekers and later replicated in cases concerning non-economic migrant Union citizens.

The 'genuine link' requirement essentially represents a permissible justification of otherwise directly or indirectly discriminatory behavior. So far, it has been employed in several of the CJEU's cases dealing with citizens' social rights. Thus, in order to come to a better understanding of this final example of a defense mechanism and the limitations existing in its application, we should consider the relevant Court's case law.

The first cases where we encounter the 'genuine link' requirement are those concerning jobseekers ${ }^{216}$. While initially introduced in the case D'Hoop ${ }^{217}$,

216 See above footnote 59.

217 Case C-224/98 D'Hoop [2002] ECR I-6191. In this case, the Court has dealt with the question of whether EU law precludes a MS from refusing to grant the tideover allowance (an unemployment benefit for young people who have just completed their studies and are seeking their first employment) to one of its own nationals, a student seeking her first employment, on the sole ground that that a student completed her secondary education in another MS. (para 16) In answering this question, the Court has found that the national legislation in question is contrary to the guarantee of equal treatment in exercise of the Union citizen's freedom to move. (para 35) Namely, by making the grant of the tideover allowance conditional upon the completion of a secondary education in that MS, the national legislation placed certain of its nationals at a disadvantage simply because they have exercised their freedom to move in order to pursue education in another MS (para 34). Such condition imposed by the national legislation could be justified only if it was based on objective considerations independent of nationality and was proportionate to the legitimate aim pursued by the national provisions. (para 36) In that regard, the Court has noted that, since the benefit in question aims at facilitating for young people the transition from education to employment market, it is legitimate for a MS to wish to ensure that there is a real 
this requirement was further elaborated in the context of prohibition of discrimination on grounds of nationality in the case Collins ${ }^{218}$. The question addressed in Collins was whether the principle of equal treatment precludes national legislation which makes entitlement to a jobseeker's allowance ${ }^{219}$ conditional on a residence requirement. ${ }^{220}$ The Court first found that, even though it imposes the same "habitual residence" requirement both on its own nationals and other MS' nationals, the national legislation in question introduced a difference in treatment. This follows from the fact that a residence requirement of that kind is capable of being more easily satisfied by the State's own nationals. It, therefore, places at a disadvantage other MS' nationals who have exercised their right to move freely in order to seek employment in the territory of another MS.221

Yet, the Court added that such difference in treatment can be justified if it is based on objective considerations independent of nationality of the persons concerned and proportionate to the legitimate aim pursued by the national provisions. ${ }^{222}$ It noted, in this respect, that, given the nature of the benefit in question, it is legitimate for a MS to wish to ensure that there is a genuine link between the applicant and the geographic employment market in question. 223 Thus, in justifying what would otherwise be considered an indirectly discriminatory measure prohibited by EU law, the MS are free to invoke the 'genuine link' requirement, which aims at ensuring a sufficient degree of connectedness between its employment market and an applicant seeking the benefit. ${ }^{224}$

The genuine link may, according to the Court, be determined by establishing

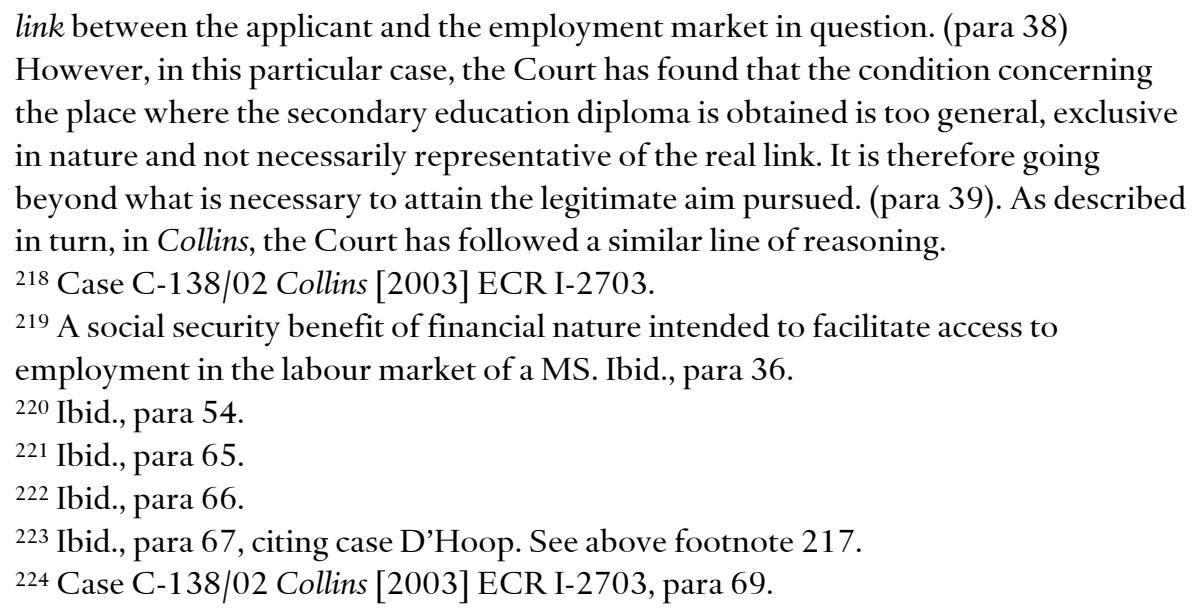


that a person concerned has, for a reasonable period, genuinely sought work in the host MS.225 As for the residence requirement, such as the one imposed by the national legislation at hand, the Court has found that such a requirement is, in principle, appropriate to ensure that there is a genuine link between the applicant and the employment market of a host MS.226 But, if it is to be proportionate, such requirement must not go beyond what is necessary in order for the national authorities to be able to satisfy themselves that the applicant in question is in fact genuinely seeking work in the employment market of a host MS.227 Also, the application of such a requirement by the national authorities must rest on clear criteria known in advance and the possibility of a means of redress of a judicial nature must be made available. 228 In the subsequent case Ioannidis 229 , the Court scrutinized, in light of the proportionality principle, a Belgian measure requiring from an applicant for a tideover allowance 230 to have either completed a secondary education in Belgium, or alternatively, in the case of jobseekers who completed their secondary education in another MS, of being dependant children of migrant workers for the purposes of Article 45 TFEU residing in Belgium.

As for condition concerning the place where the diploma of secondary education was obtained, the Court found that it could place nationals of other MS at a disadvantage. Therefore, it can be justified only by objective considerations independent of nationality of the persons concerned and proportionate to the aim legitimately pursued by the national law. ${ }^{231}$ In that regard, the Court has reasserted that it is legitimate for the national legislature to wish to ensure that there is a real link between the applicant for that allowance and the geographic employment market concerned.232 However, in line with its earlier case law 233 , the Court found that this particular condition imposed by the national legislation was too general, exclusive in nature and that it unduly favors an element which is not necessarily representative of the real and effective degree of connection between the

\footnotetext{
225 Ibid., para 70.

226 Ibid., para 72.

227 Ibid.

228 Ibid.

${ }^{229}$ Case C-258/04 Ioannidis [2005] I-08275.

${ }^{230}$ An unemployment benefit intended for young people who have just completed their studies and are seeking for their first employment.

231 Case C-258/04 Ioannidis [2005] I-08275, paras 28, 29.

232 Ibid., para 30.

${ }^{233}$ Namely, the case D'Hoop. See above footnote 217.
} 
applicant and the employment market. ${ }^{234}$ Based on this, the Court has concluded that the national measure in question did not comply with the principle of proportionality, as it went beyond what is necessary to attain the objective pursued. ${ }^{235}$

In the recent case Prete, the Court applied the same reasoning and affirmed this conclusion. ${ }^{236}$ In addition, it scrutinized the national measure making the right to a tideover allowance subject to the condition that a claimant has completed at least six years' studies in an educational establishment of the host Member State. It concluded that this requirement, inasmuch as it prevents other potentially representative factors of the real degree of connection from being taken into account, goes beyond what is necessary to attain the objective pursued and, thus, fails to comply with the principle of proportionality. ${ }^{237}$

In the earlier case Ioannidis, the Court was also asked whether it is justified to require from an applicant for a tideover allowance who has completed his/her secondary education in another MS, to be a child of migrant workers residing in Belgium. The Court found that this condition is based on an element which can be considered as representative of a real and effective degree of connection. Yet, it cannot be justified by the wish to ensure that there is a real link between the applicant and the employment market concerned. According to the Court, it is not inconceivable that a person, such as Mr. Ioannidis, who, after completing his secondary education in a Member State, pursues higher education in another Member State and obtains a diploma there, may be in a position to establish a real link with the employment market of that State, even if he is not the dependent child of migrant workers residing in that State. ${ }^{238}$ Thus, such a condition goes beyond what is necessary to attain the objective pursued. 239

What seems to emerge from this case law concerning jobseekers is that the Court has provided the MS with a yet another defense mechanism for protecting their public finances. It did so by allowing them the possibility of justifying unequal treatment between their nationals and other Union citizens

\footnotetext{
${ }^{234}$ Case C-258/04 Ioannidis [2005] I-08275, para 31.

235 Ibid.

${ }^{236}$ Case C-367/11 Prete [2012] ECR 00000, para 34.

237 Ibid, paras 51, 53.

${ }^{238}$ Case C-258/04 Ioannidis [2005] I-08275, para 33.

${ }^{239}$ Ibid.
} 
in access to social benefits through the 'genuine link' requirement. However, by requiring the MS to comply with the principle of proportionality when they apply this justifiable criterion in concrete cases, the Court has limited their discretion. In turn, it has also limited the protective effects that this defense mechanism might have on their social security schemes.

Shortly after Collins, the Court adopted a very similar line of reasoning in the case Bidar ${ }^{240}$. Unlike the previous cases, Bidar concerned non-economic migrants. In particular, it concerned students seeking educational benefits. The Court was asked in this case whether EU law, particularly the principle of equal treatment enshrined in Article 18, precludes the UK legislation which makes entitlement to a student maintenance assistance conditional on a requirement of three years of prior residence in the UK, as well as a requirement of being settled in the $\mathrm{UK}^{241}$.

In answering this question, the Court started with the observation that the requirements in question risk placing at a disadvantage nationals of other MS, as they are both likely to be more easily satisfied by the UK nationals. ${ }^{242}$ By relying on its earlier case law, the Court then reasserted that such difference in treatment can be justified only if it is based on objective considerations independent of the nationality of the persons concerned and is proportionate to the legitimate aim pursued by the national provisions. ${ }^{243}$

Regarding a possible justification of the unequal treatment in question, the Court observed that "although the Member States must, in the organization and application of their social assistance systems, show a certain degree of financial solidarity with nationals of other Member States $[\ldots]$, it is permissible for a Member State to ensure that the grant of assistance to cover the maintenance costs of students from other Member States does not become an unreasonable burden which could have consequences for the overall level of assistance which may be granted by that State". ${ }^{244}$ In view of

\footnotetext{
240 Case C-209/03 Bidar [2005] ECR I-2119.

${ }^{241}$ Under the UK legislation, the person is settled in the UK if he/she is ordinarily resident there without being subject to any restriction on the period for which he may remain in the territory. As became clear from the national case law submitted to the Court, this requirement is impossible of being satisfied by nationals of other MS in their capacity as students. Ibid., para 17, 18.

242 Ibid., para 53.

243 Ibid., para 54.

244 Ibid., para 56.
} 
that, the Court found that it is legitimate for a MS to grant assistance covering maintenance costs of students, only to those students who have demonstrated a certain degree of integration into the society of that MS. ${ }^{245}$ Such a genuine link with the MS's society can, in the Court's opinion, be established by finding that the student in question has resided in the host Member State for a certain length of time. ${ }^{246}$ However, having in mind its earlier case law ${ }^{247}$, the Court clarified that a host MS cannot require from students to establish a link with the employment market concerned, since the situation of students who apply for student maintenance assistance cannot be compared to that of applicants for a tideover or a jobseeker's allowance. ${ }^{248}$

As for the concrete requirements imposed by the UK legislation, the Court has found that both the "three years of previous residence" requirement, as well as the requirement of being settled in the UK, correspond to the legitimate aim in question. Yet, while the requirement of prior residence was considered as justified, this was not the case when it came to the requirement of being settled in the territory of the UK. The Court based this conclusion on the fact that the criterion of being settled in the UK is impossible of being satisfied by nationals of other MS in their capacity as students. ${ }^{249}$ Thus, by imposing such a requirement, the national legislation prevented all students from other MS, including those who have already established a genuine link

${ }^{245}$ Ibid., para 57. Thus confirming that the legitimate aim justifying the unequal treatment in question is that of protecting the MS public finance from unreasonable burdens from abroad. As AG Sharpston further explains in her Opinion in Case C-542/09 Commission v Netherlands, in Bidar, "evidence of a degree of integration was treated as a means to avert an unreasonable financial burden.” (para 84).

${ }^{246}$ Case C-209/03 Bidar [2005] ECR I-2119, para 59. It should be noted that the Court explicitly uses the expression 'genuine link' in paragraph 62 of this judgment, thus confirming that the inspiration for the introducing such requirement in case of students is clearly drawn from the Court's earlier case law concerning jobseekers. Also see Case C-75/11 Commissionv Austria [2012] ECR 00000, para 59.

247 That is, the cases Ioannidis, Collins and D'Hoop, described above.

${ }^{248}$ Case C-209/03 Bidar [2005] ECR I-2119, para 58. It should be noted, however, that regardless the fact that the Court has emphasized a distinction between the requirement concerning a sufficient degree of integration into the host MS society and the requirement concerning a genuine link with the host MS' employment market, both of these (supposedly) divergent requirements have, so far, always materialized as essentially the same "length of residence" requirement. See Koen Lenaerts and Tinne Heremans, 'Contours of a European Social Union in the CaseLaw of the European Court of Justice’ (2006) 2 EuConst 101, p. 107.

${ }^{249}$ Ibid., para 18, 61. 
with the host MS society, from enjoying the right to student maintenance assistance. ${ }^{250}$ For that reason, the Court concluded that such treatment could not be justified by the legitimate aim pursued by the national rules and is, thus, contrary to the Article 18 equal treatment guarantee. 251

In this way, once again, the Court confirmed that a 'genuine link' requirement could be used to justify unequal treatment by national authorities. At the same time, it confirmed that the application of this defense mechanism is significantly restricted by the principle of proportionality.

The cases considered above demonstrate that the 'genuine link' requirement was first elaborated in cases concerning indirect discrimination. Soon after, the Court has confirmed that it can also be used as a justifiable criterion in cases concerning unequal treatment that would otherwise amount to direct discrimination.

The first, and so far the only example of this interpretation can be found in the case Förster ${ }^{252}$. Like Bidar, this case also concerned the rights of students

250 Ibid., para 61, 62.

${ }^{251}$ Ibid., para 63. Unfortunately, it does not seem entirely clear on which step of the proportionality test did this requirement fall. What seems to emerge from the Court's reasoning is that the measure has fallen because it is too narrowly tailored (since it excluded from access to the benefit already integrated foreign students) and is, thus, incapable of achieving the legitimate aim in question. The fact that the Court has not clearly distinguished the steps in its analysis makes it difficult to assess the exact limitations in the application of the defense mechanism in question.

252 Case C-158/07 Förster [2008] ECR 00000. Also see Anne Pieter Van der Mei, 'Union Citizenship and the Legality of Durational Residence Requirements for Entitlement to Student Financial Aid' (2009) 16 Maastricht Journal of European and Comparative Law 494; and Síofra O'Leary, 'Equal treatment and EU citizens: A new chapter on cross-border educational mobility and access to student financial assistance' (2009) 34(4) E.L. Rev. 612, pp. 621-622. However, AG Sharpston does not seem to share that opinion. In her Opinion delivered in the case C-73/08 Bressol [2010] ECR 00000, she asserted that, to the best of her knowledge, "the Court has never held that a measure that discriminates directly on grounds of nationality, contrary to Article 12 EC, may be justified" (para 128). She added that "according to settled case-law, [direct] discrimination can only be justified on the basis of explicit Treaty derogations", which do not exist in the case of "the general prohibition on discrimination on grounds of nationality contained in Article 12 EC" (para 129). It is interesting to note that AG Sharpston's Opinion in this case does not make mention of the case Förster at any point. The Court's judgment in the case Bressol, on the other 
in access to educational benefits. In it, the Court was asked to decide whether the principle of equal treatment enshrined in Article 18 precludes the national (Dutch) legislation which makes entitlement to a student maintenance grant of non-economic Union citizens who are nationals of other MS, conditional on a requirement of five years of continuous prior residence in the territory of the host MS.

It should first be observed that that this case concerned direct discrimination on grounds of nationality. The requirement of five years of prior residence in the Netherlands was applied only to students who are nationals of other MS, not to Dutch nationals seeking access to maintenance grants. In assessing whether such a directly discriminatory requirement complies with EU law, the Court reasserted that it is legitimate for the MS to ensure that the grant of student assistance does not become an unreasonable burden for the host MS's public finances and to grant such benefits only to those students who have established a certain degree of integration with the host MS society. 253

hand, provides no clarification in that respect, as it refuses to explicitly address the question of possible justifications of direct discrimination on grounds of nationality. In her subsequent Opinion in Case C-542/09 Commission v Netherlands (para 83), AG Sharpston made explicit mention of case Förster and described it as a case of indirect discrimination, albeit justified according to the Court.

${ }^{253}$ Ibid., paras 48, 49. In Bidar (paras 56, 57) it seemed quite clear that establishing a degree of connection with the host MS society is treated as a means to pursue the legitimate objective of averting an unreasonable financial burden. The same conclusion derives from the Court's reasoning in Cases C-11 and 12/06 Morgan and Bucher [2007] ECR I-8507 (para 43). However, this conclusion does not unambiguously flow from the Court's analysis in Förster (paras 48, 49). Even though the Court in paragraphs 48,49 of its Förster ruling relies directly on its reasoning in Bidar, the wording of these paragraphs seems to indicate that ensuring integration of the student is not merely a means of avoiding the collapse of the social scheme due to its financial cost, but a legitimate objective of its own. See Anne Pieter Van der Mei, 'Union Citizenship and the Legality of Durational Residence Requirements for Entitlement to Student Financial Aid' (2009) 16 Maastricht Journal of European and Comparative Law 494, p. 488. If this is the correct reading of the Förster judgment, this kind of a change in the Court's reasoning is not only confusing, but also worrying. As AG Sharpston explains: "It would be unfortunate if a superficial reading of Förster were to lead to confusion between means and end. There is a risk that Förster might be read as indicating that Member States can set a residence requirement, irrespective of whether its purpose is to ensure that making available a social advantage does not adversely affect the stability of its public finances or the pursuit of any other legitimate objective justified by overriding reasons of public interest. On that basis, Member 
Furthermore, it reiterated that the existence of the required degree of integration may be regarded as established by finding that a student seeking the benefit has resided in the host MS for a certain length of time. ${ }^{254}$

The Court then proceeded to analyze whether the requirement of five years of prior residence, such as the one at hand, can be regarded as justified by the objective of ensuring that students who are nationals of other MS have a sufficient degree of integration with the host MS's society. In that way, the Court basically confirmed that a case of direct discrimination on grounds of nationality could be justified by the same 'genuine link' requirement previously employed in the cases of indirect discrimination. In line with its earlier case law, the Court added that in order to be justified, the requirement in question must be appropriate and proportionate to the legitimate objective pursued by the national provisions. ${ }^{255}$ This implies that it must not go beyond what is necessary to attain the objective pursued and must be applied by the national authorities on the basis of clear criteria known in advance. ${ }^{256}$

States might seek to justify less favourable treatment of (both economically active and inactive) EU citizens in terms of social policy (integration) by applying access criteria such as length of residence, marital and family status, language, diplomas, employment, and so forth, without ever explaining why the availability of a social benefit should be limited in that way." See AG Sharpston's analysis in Case C-542/09 Commission $v$ Netherlands, para 85. The lack of clarity as to what are the means and what are the ends is also present in the Case C-503/09 Stewart [2011] ECR I-0000. Throughout this judgment, the Court clearly distinguishes between the legitimate objective of ensuring a genuine link between a claimant to a benefit and the competent Member State, and the legitimate objective of guaranteeing the financial balance of a national social security system (paras $89,90,108$ ). Yet, in paragraph 103 , the Court proclaims that its considerations regarding the degree of connection with the competent Member State also apply with regard to the objective of guaranteeing the financial balance of the national social security system, since "the necessity of establishing a genuine and sufficient connection between the claimant and the competent Member State enables that State to satisfy itself that the economic cost of paying the benefit at issue in the main proceedings does not become unreasonable." In this way, the Court seems to reaffirm its reasoning in Bidar. The same conclusion seems to derive from the judgment in Case C-542/09 Commission v Netherlands [2012] ECR 00000, paras 59, 60 and case C-75/11 Commission v Austria [2012] ECR 00000 , paras 60, 61 .

${ }^{254}$ Case C-158/07 Förster [2008] ECR 00000, para 50.

255 Ibid., paras 52, 53.

256 Ibid., paras 53, 56. 
In assessing whether the case at hand complies with the EU law requirements, the Court found that the condition of five years of prior residence in the host MS territory constitutes an appropriate measure for establishing a genuine link with the host MS's society. ${ }^{257}$ As far as the proportionality requirement is concerned, the Court concluded that the condition in question complies with the requirements of legal certainty and transparency, since it was clearly laid down in advance in national legislation. ${ }^{258}$

Additionally, without seriously scrutinizing the condition in question, the Court was fast to conclude that such a 5 years of residence requirement is not excessive, since it does not go beyond what is necessary to attain the objective pursued. ${ }^{259}$ To support its conclusion, the Court invoked Article 24(2) of Directive 2004/38. Although not applicable to the facts of this case, this provision also makes the entitlement to grant maintenance assistance for studies conditional upon the period of five years of lawful residence (which is the period needed for acquiring the status of permanent resident) in the case of non-economic Union citizens residing in the territory of a host MS. ${ }^{260}$ The Court thus relied on the explicit derogation to equal treatment prescribed in the Citizens' Rights Directive to justify the case of direct discrimination before it.

The Court's reasoning is quite indicative. It shows us that Article 24(2) derogation to equal treatment, which at first sight appears as a separate defense mechanism, in fact seems to be a mere reflection of the 'genuine link' requirement. ${ }^{261}$ This would suggest that the 'genuine link' requirement, ensuring a sufficient degree of connectedness between a student and the host MS' society, and the derogation to the principle of equal treatment on grounds of nationality prescribed in Article 24(2) of Directive 2004/38 in relation to students who claim access to maintenance aid for studies, essentially represent the same defense mechanism. ${ }^{262}$

\footnotetext{
257 Ibid., para 52.

258 Ibid., para 56.

259 Ibid., para 54.

${ }^{260}$ Ibid., para 55.

261 This conclusion also seems to be derive from the Court's reasoning in the case C-542/09 Commission v Netherlands [2012] ECR 00000, paras 63, 64. Also see Koen Lenaerts, 'European Union Citizenship, National Welfare Systems and Social Solidarity' (2011) 18(2) Jurisprudence 397, p. 401.

262 Given the fact that the Court has drawn inspiration from the cases concerning jobseekers to introduce the 'genuine link' requirement as a permissible justification of
} 
More importantly, the Court's lenient approach and the low level of scrutiny applied when assessing the proportionality of the national measure seem to indicate that, by upholding the 5 years of residence requirement, the Court has shown a clear reluctance to second-guess the political process that had taken place at the Union level when the Citizens' Rights Directive was adopted. ${ }^{263}$ Furthermore, such a refusal to subject the national measure in question to a more serious level of scrutiny seems to demonstrate that the Court has decided to backtrack on its progressive interpretation of the concept of Union citizenship. ${ }^{264}$

The question that inevitably arises in this context is what is left of Union citizens' social rights after the Court has assumed such a regressive approach. Can we truly speak of the "new models of social solidarity" being generated at the Union level, or would that seem greatly exaggerated and distant from reality after the Förster ruling?

unequal treatment in the cases concerning students' access to maintenance assistance, it appeared that the same conclusion can be reached in relation to the 'genuine link' requirement applicable to jobseekers and the derogation to equal treatment of jobseekers prescribed in Article 24(2). However, the recently decided joined cases C-22/08 \& C-23/08 Vatsouras and Koupatantze [2009] ECR 00000 seem to suggest that the 'genuine link' requirement applied in the cases concerning the jobseekers' right to access social benefits intended to facilitate employment and the Article 24(2) derogation to equal treatment of jobseekers covered by Article 14(4)(b) of Directive $2004 / 38$ are not a reflection of one another. This follows from the Court's interpretation of Article 24(2), whereby it concluded that "benefits of a financial nature which $[\ldots]$ are intended to facilitate access to the labour market cannot be regarded as constituting 'social assistance' within the meaning of Article 24(2) of Directive 2004/38" (see Vatsouras and Koupatantze, para 39). While it is yet to be seen exactly what kinds of benefits are covered by this Article, it seems quite clear that after this case we cannot refer to the part of Article 24(2) concerning jobseekers as a codification of the 'genuine link' requirement developed by the Court in D'Hoop, Collins and Ioannidis in relation to access to jobseekers' allowances. Also see Koen Lenaerts, 'European Union Citizenship, National Welfare Systems and Social Solidarity' (2011) 18(2) Jurisprudence 397, p. 404.

${ }^{263}$ See Anne Pieter Van der Mei, 'Union Citizenship and the Legality of Durational Residence Requirements for Entitlement to Student Financial Aid' (2009) 16 Maastricht Journal of European and Comparative Law 494, pp. 489, 490; Síofra O'Leary, 'Equal treatment and EU citizens: A new chapter on cross-border educational mobility and access to student financial assistance' (2009) 34(4) E.L. Rev. 612, pp. 622-623; and Koen Lenaerts, 'European Union Citizenship, National Welfare Systems and Social Solidarity' (2011) 18(2) Jurisprudence 397, p. 407. ${ }^{264}$ Ibid. 
To a certain extent, it seems that, by adopting such a reasoning, the Court has not only made a significant step back in developing the social rights of noneconomically active Union citizens, but it has virtually stripped them of all the positive effects arising from the co-called fundamental status of Union citizenship. Yet, in order to answer these questions to best depict the current status quo of EU citizens' social rights, one should also bear in mind that the 'genuine link' requirement has so far been applied only to one category of non-economic Union migrants, namely students. Also, before drawing any overly pessimistic conclusions from the Court's case law, one should bear in mind the fact that the 'genuine link' requirement remains surrounded with much ambiguity, which will hopefully be clarified by the Court in the near future.

In that regard, it remains to be seen is whether national measures relying on Article 24(2) will be subject to the proportionality assessment or not. As discussed above, Article 24(2) seems to represent a reflection of the Court's case law in which the 'genuine link' requirement was developed. ${ }^{265}$ Accordingly, one might presume that the Court will continue to apply the same limitations to the MS' action when they rely on the explicit derogation prescribed in this Article, as it did in the cases where the MS have resorted to the 'genuine link' requirement in order to justify their discriminatory behavior. In other words, one might expect that in future cases where the MS apply Article 24(2) derogation to equal treatment, their discretion will be limited by the application of the principle of proportionality, in the same way as it was in the cases described above. ${ }^{266}$ However, the explicit reference to Article 24(2) made within the proportionality assessment in Förster, might suggest the opposite. It might indicate that, having upheld the 5 years of residence requirement as proportionate, in particular given the existence of the equivalent requirement in EU law, the Court might regard any future national measures relying Article 24(2) as automatically complying with the principle of proportionality - thereby making any further assessments of the validity of such measures superfluous.

Yet another open question is whether the CJEU's interpretation of the

265 This conclusion seems to be valid at least when it comes to students' rights. See above footnote 262 .

${ }^{266}$ For an additional argument regarding the application of the principle of proportionality to the MS action when relying on the explicit derogations in Article 24(2) of Directive 2004/38, see Michael Dougan, 'The constitutional dimension to the case law on Union citizenship’ (2006) 31(5) E.L. Rev 613. 
genuine link requirement as a justifiable criterion for unequal treatment that would otherwise amount to direct discrimination should be seen as an isolated case, or could this sort of justification be applied beyond cases covered by Article 24(2) of the Citizens' Rights Directive. In addition, what needs to be clarified is the exact meaning of the 'genuine link' and which methods can be used to determine it. While the 'genuine link' requirement has often materialized as the "length of residence" requirement, the Court made it clear that it may be interpreted more broadly, so as to encompass other representative elements of a genuine link between a claimant and a host MS in question. ${ }^{267}$ This is evident from the Court's reasoning in Collins, where it stated that the genuine link may be determined by establishing that a person concerned has, for a reasonable period, genuinely sought work in a host MS. ${ }^{268}$ This is also evident from the cases Stewart ${ }^{269}$ and Prete ${ }^{270}$, where the

${ }^{267}$ See Koen Lenaerts and Tinne Heremans, 'Contours of a European Social Union in the Case-Law of the European Court of Justice' (2006) 2 EuConst 101, p. 107; and Koen Lenaerts, 'European Union Citizenship, National Welfare Systems and Social Solidarity' (2011) 18(2) Jurisprudence 397, p. 418.

268 Case C-138/02, Collins [2003] ECR I-2703, para 70. Also see joined cases C-22/08 \& C-23/08 Vatsouras and Koupatantze [2009] ECR 00000, para 39. ${ }^{269}$ Case C-503/09 Stewart [2011] ECR I-0000. In particular, this case concerned Ms Stewart, a British national who moved with her parents to Spain and subsequently applied to the UK for short-term incapacity benefit in youth. Her application was refused on the ground that she was not present in the UK at the time of applying and had not been in the UK for at least 26 weeks in the year preceding the application, as required under the UK law. Following Ms Stewart's appeal, the national court asked the CJEU to determine whether these requirements were compatible with EU law. The Court held that it is in principle legitimate to seek to establish a genuine link between a claimant to short-term incapacity benefit in youth and the competent Member State, as well as to guarantee the financial balance of a national social security system (para 89). However, it found the UK requirements in question to constitute disproportionate methods for fulfilling these legitimate objectives. As far as the condition of presence on the date on which the claim is made is concerned, the Court found that it does not constitute an appropriate means of attaining the objectives in question and thus amounts to an unjustified restriction on the freedoms guaranteed by Article 21(1) TFEU (paras 108, 109). As far as the condition of past presence of the claimant in the UK is concerned, the Court found it to be too exclusive in nature. More concretely, it found that this condition unduly favors elements which are not necessarily representative of the real and effective degree of connection between the claimant to short-term incapacity benefit in youth and that Member State, to the exclusion of all other representative elements (para 95). As such, it goes beyond what is necessary to attain the objective pursued and therefore amounts to an unjustified restriction on the freedoms guaranteed by Article 21(1) TFEU (para 104). 
Court held that matters which can be inferred from the family circumstances of a claimant of a benefit are capable of demonstrating the existence of a genuine link between the applicant and the host Member State. ${ }^{271}$ Finally, this is evident from the recent case Commission v. Austria, in which the Court clarified that the genuine link required between a student claiming a benefit and a host Member State need not be fixed in a uniform manner for all benefits, but should be established "according to the constitutive elements of the benefit in question, including its nature and purpose or purposes". 272

In this specific case, this has led the Court to conclude that the existence of a genuine link for the purpose of the reduced transport fares for students could be ascertained, inter alia, by checking whether the person is enrolled at a private or public establishment, accredited or financed by the host Member State, for the principal purpose of following a course of study, including vocational training. ${ }^{273}$ Conversely, granting reduced fares on public transport in principle only to students whose parents are in receipt of the host Member States' family allowances, was not considered by the Court as justified. ${ }^{274}$ It should be noted, however, that this part of the Court's judgment declaring the national measure in question incompatible with the Treaty provisions is not free from ambiguity. It is not clear whether the Austrian scheme was

\footnotetext{
As far as other representative elements of the real and effective degree of connection between the claimant of the benefit and the competent State are concerned, the Court elaborated that such elements must be sought "in the relationship between the claimant and the social security system of the competent Member State" or even the “claimant's family circumstances" (paras 96, 97, 100). The Court concluded that these considerations also apply to the objective of guaranteeing the financial balance of the national social security system, as the necessity of establishing a genuine and sufficient connection between the claimant and the competent Member State enables that State to satisfy itself that the economic cost of paying the benefit at issue in the main proceedings does not become unreasonable (para 103).

270 Case C-367/11 Prete [2012] ECR 00000 More specifically, the Court declared that "the existence of close ties, in particular of a personal nature, with the host Member State where the claimant has, following her marriage with a national of that Member state, settled and now habitually resides are such as to contribute to the appearance of a lasting connection between the claimant and the Member State in which she has newly established herself, including with the labour market of the latter". See para 50. 271 See ibid.

272 Case C-75/11 Commissionv Austria [2012] ECR 00000, para 63.

273 Ibid., para 64.

${ }^{274}$ Ibid., paras 65, 66.
} 
deemed unjustified because it was "too exclusive in nature" 275 ; because it "unduly favour(s) an element which is not necessarily representative of the real and effective degree of connection" 276 ; or because it was "set in a uniform manner" rather then "established according to the constitutive elements of the benefit in question, including its nature and purpose or purposes" 277. Even though not entirely clear in itself, the Advocate General's Opinion in this case, on which the Court has heavily relied, seems to indicate that that the measure in question has 'fell' because it is too excessive given the nature of the benefit, thus going beyond what it necessary to attain the objective pursued. ${ }^{278}$

All in all, it remains to be seen in the future what precisely will become of the 'genuine link' requirement as the last defense mechanism left at the MS' disposal. For now, we can conclude that even in situations where seemingly all conditions for access to equal treatment of non-economic EU migrants are fulfilled, there are still ways provided for the MS to protect their social systems and, more generally, public purses from potential intrusions from abroad.

\subsection{Conclusion}

In the past two decades, the evolvement of citizens' social rights has taken a direction neither intended by the Member States nor foreseen by those who participated in discussions about the meaning and the potential of the concept of EU citizenship. By interpreting the Treaty provisions on EU citizenship in conjunction with the freedom from discrimination on grounds of nationality to gradually expand citizens' social rights, the CJEU has played an important role in defining the contours of what may be termed as "social citizenship" 279 .

More generally speaking, via the medium of Union citizenship, the European

\footnotetext{
275 Ibid., para 62.

276 Ibid.

277 Ibid, para 63.

278 See Opinion of Advocate General Kokott in the case C-75/11 Commission v Austria [2012] ECR 00000, paras 75, 76, 77.

279 This term, which essentially stands for the social dimension of EU citizenship and thus the social rights attached to this concept, is borrowed from Jo Shaw, 'Citizenship of the Union: Towards Post-National Membership?', in the European University Institute (ed), Collected Courses of the Academy of European Law 1995, Vol. VI, Book 1 (Kluwer, The Hague 1998).
} 
integration was taken to a new level comprising not only markedly economic features, but also the social ones. This is yet another proof of the fact that the model of European integration is no longer restricted to purely economic integration. Rather, it increasingly shows signs of reorientation towards "political integration" - in which a degree of social solidarity and a certain level of protection of social rights are required as the consequence of a membership in such a community, and not only as a means of securing a level playing field and fair competition. ${ }^{280}$ This tendency "to rebalance the weight of market and non-market values" has been recently confirmed in Articles 2 and 3 of the TEU, which make a strong reference to values such as solidarity, social justice and protection, social cohesion and the well-being of the peoples of the Union. ${ }^{281}$

Yet, despite this more extended formulation of the basic values and goals of the European integration and the undisputable expansion of social rights at the Union level, EU law still provides the MS with a substantial degree of discretion in the social policy field and a significant level of protection of their financial and welfare systems. This is best exemplified by the analyzed legislation and case law concerning the defense mechanisms left at the MS disposal.

The main reason and justification for providing these defense mechanisms is the omni-present concern that the MS should not suffer "unreasonable burdens" on their social assistance systems and, generally, public finances. The frequent invocation of this reasoning in the framing of the Union's policies, and in their interpretation by the Union's highest court, shows a considerable amount of sensitivity towards the MS' welfare and financial interests.

For the MS, however, the positive effects of this approach are limited by the primary EU law requirement to comply with the principle of proportionality and other general principles of EU law. Regardless the degree of scrutiny applied by the Court in particular cases, the assessment of compliance of the

\footnotetext{
280 The terms and the concepts of "political integration" and "economic integration" are borrowed from Miguel Poiares Maduro. See Miguel Poiares Maduro, 'Striking the Elusive Balance Between Economic Freedom and Social Rights in the EU' in Philip Alston (ed), The EU and Human Rights (OUP, Oxford 2000), p. 466.

${ }^{281}$ Dragana Damjanovic and Bruno de Witte, 'Welfare Integration through EU Law: The Overall Picture in the Light of the Lisbon Treaty', EUI Working Paper LAW No. 2008/34, p. 25.
} 
MS' action with these principles, to a certain degree, constrains the benefits of the defense mechanisms.

This 'give and take' nature of EU law in the social rights field is indicative of the ways in which tensions inherent to this field have been addressed at the Union level and the ways in which the Union legislator and the CJEU have so far defined the scope and content of social rights of EU citizens. It shows that the social dimension of Union citizenship has been developed primarily as a consequence of (overt or covert) attempts to balance between the goal of promoting free movement and solidarity across the Union, and the goal of safeguarding the MS' welfare systems and public finances, without ever giving clear priority to either of them. It can therefore be concluded that, rather then being a product of a clear conception of social protection ${ }^{282}$, social rights of Union citizens have thus far come about mainly as a consequence of a case-bycase approach driven by balancing and "ad hoc political bargains" 283 .

This arbitrariness in developing the social dimension of EU citizenship points to a more general conclusion. It shows that, at the EU level, there is a lack of perspective and plan for defining social rights attached to the so-called fundamental status of Union citizenship. Specifically, it indicates that there exists no agreement on the core set of European social values, no clear underlying rationale commanding social developments of the concept of EU citizenship, no criteria of distributive justice at the EU level and, in general, no idea of what the European social identity should consist of. ${ }^{284}$ As a result, the precise path to be taken in relation to development of Union citizens' social rights is far from being determinate.

282 See footnote 23 above, pp. 337, 340, 342.

283 This terminology is borrowed from Miguel Maduro. Ibid.

${ }^{284}$ Maduro has in that regard rightly argued that the European Union should no longer avoid dealing with this issue in a coherent manner and, in that sense, defining its “social self”. See ibid. For a similar argument, see Kay Hailbronner, 'Union Citizenship and Access to Social Benefits' (2005) 42 CML Rev. 1245, p. 1267. Besides the fact that this is needed in order to complete the construction of the concept of Union citizenship, this requirement is also justified by the concern that the expansion of social rights "without an appropriate framework of legitimacy identifying their status and overall placing in the European political project will raise potential conflicts of rights without appropriate criteria to regulate them”. Miguel Poiares Maduro, 'Europe's Social Self: The Sickness Unto Death' in Jo Shaw (ed), Social Law and Policy in an Evolving European Union (Hart Publishing, Oxford 2000), p. 339. 


\section{Chapter II - Addressing EU citizens' social rights developments at the national level}

\subsection{Introduction}

The analysis undertaken in the preceding chapter has revealed the new pace of evolvement of the concept of Union citizenship and, particularly, its social aspect during the past two decades. This dynamic has taken the European project in the direction of an increased regulation of the area of social policy at the Union level and the expansion of EU citizens' social rights. The most important development concerned the CJEU's expansive interpretation of the concept of EU citizenship, whereby it guaranteed the right to equal treatment in access to social benefits to Union citizens lawfully residing in a MS of which they are not nationals, provided that their situation falls within the material Treaty scope.

Yet, despite this initial expansion of the social dimension of EU citizenship, the analysis revealed a nuanced approach by both the CJEU and the Union legislator. This approach is marked by a tendency to balance between the opposing interests and goals in the social policy field - that is, the aim of promoting social solidarity and free movement across the Union, and the aim of safeguarding the MS' financial interests and welfare systems - without ever giving a clear priority to one over the other. As a consequence, it is hard to reach a conclusion that a further expansion of citizens' social rights is what can be expected in the future. In fact, given this approach and the resulting 'give and take' nature of EU law in the social policy field, it is impossible to predict the future course of development this aspect of European integration. The only conclusion one can reach is that, so far, no clear guidelines or a framework for development of citizens' social rights have been put in place. Rather, the overall process of evolvement of the social dimension of European citizenship has come as a product of random bargains at the legislative level and a case-by-case approach driven by balancing at the judicial level. 
In the Member States, the tendency of approaching social rights' and other developments in EU law is rather different. The behavior of national actors dealing with primary EU law amendments reveals an increasingly popular approach whereby a priority is given to the preservation of the MS' sovereignty in areas of vital state interest, including the social policy field. This approach, which I term 'the sovereignty-related approach', basically amounts to conditioning any future developments in EU law upon the preservation of states' core sovereign powers.

The legal aspect and outlines of this recurrent approach assumed at the national level are most clearly visible in the MS' constitutional and supreme courts' case law concerned with primary EU law amendments. In order to describe the exact terms and popular character of the sovereignty-related approach, the remainder of this chapter will be devoted to this line of national case law. As the analysis will show, by consistently scrutinizing Treaty amendments under the sovereignty-related approach, crucial national judicial actors have set a strong trend in conditioning actual and potential changes in EU law, including those in the social policy field, upon the preservation of the core of state sovereignty. This also implied setting the boundaries for further development of the social dimension of EU citizenship, which pertains to this broader field.

\subsection{The sovereignty-related approach}

The history of the European integration has been marked by over a dozen amendments of the founding treaties. ${ }^{285}$ Those amendments have led to a gradual shaping of the European integration into a close association of states, gathered not only around economic goals, but also around certain political and social values. This evolutionary trend became particularly visible with the introduction and development of the concept of Union citizenship. ${ }^{286}$

However, the process of evolvement of the European project in this direction has not been an entirely smooth one. On the contrary, the processes of amending the primary EU law have often been marked by agitated negotiations and slow ratification procedures on part of the MS' actors

\footnotetext{
285 See further http://europa.eu/abc/treaties/index_en.htm.

286 See further Gillian More, 'The Principle of Equal Treatment: From Market Unifier to Fundamental Right?' in Paul Craig and Gráinne de Búrca (eds), The Evolution of EU Law (OUP, Oxford 1999).
} 
participating in them. Moreover, the occasional inability of those actors to reach compromises on certain issues on the European level has sometimes lead to prolonged periods of stagnation in development of EU law.287 The most recent examples of such lengthy processes of negotiations and ratifications of Treaty amendments concern the rejected Treaty establishing a Constitution for Europe, and the subsequently adopted and successfully ratified Lisbon Treaty.

There are two predominant reasons for such a heavy and lingering character of Treaty amendments. The first, procedural one concerns the need for the unanimity requirement to be satisfied in case of every Treaty amendment that comes to the table. More specifically, whether the Treaties are amended in accordance with an ordinary or a simplified revision procedure, unanimity always needs to be reached within the final decision-making body for envisaged changes to be adopted. ${ }^{288}$ What additionally hardens the already difficult procedure of changing primary EU law is the requirement necessitating all of the MS to ratify the adopted amendments, so that they could enter into force.

The second, substantive reason and perhaps the most distinctive feature of the related negotiation and ratification procedures, lies in the specific type of behavior assumed by MS' actors participating in them. If one observes the arguments advanced by MS' political and judicial actors forming a part of those procedures, one will note the existence of a certain trend, continuously present throughout the history of European integration. This trend consists in invoking the concept of state sovereignty when changes of EU law are being discussed at the national level and scrutinized under national constitutional norms.

To be exact, debates regarding the development of European integration and

\footnotetext{
${ }^{287}$ Perhaps the most notable example of such a decline of decision-making processes at the European level is the crisis that has emerged in the 1960s and has resulted in the adoption of the famous Luxembourg Accords. See further, Gráinne de Búrca and Paul Craig, EU Law: Text, Cases and Materials (2 ${ }^{\text {nd }}$ edn OUP, Oxford 1998), pp. 13-19.

${ }^{288}$ In the case of an ordinary revision procedure, the body that has to reach a decision by common accord is a conference of representatives of the governments of the MS, whereas in the case of a simplified revision procedure, the body that has to act by unanimity in order to adopt Treaty amendments is the European Council. See Article 48 of the TEU, Consolidated versions of the Treaty on European Union and the Treaty on the Functioning of the European Union, Official Journal C 115 of 9 May 2008 ('the TEU').
} 
EU law in particular often seemed to have been dominated by what I will refer to as the sovereignty-related approach and the consequent employment of the sovereignty-related rhetoric. As the analysis below will show, this approach reveals a considerable amount of concern expressed by MS' actors that the evolvement of certain rights and duties on the European level might lead to a loss, or an unauthorized limitation of the MS' sovereignty. In that regard, the usual reasoning on part of the MS' legal actors consists in the following: as long as changes in EU law do not threaten the state's core sovereign powers, such changes will be regarded as compatible with MS' fundamental constitutional principles and, therefore, as acceptable. In other words, according to this approach, future developments of EU law will be regarded as acceptable so long as they do not represent a serious and existential threat to the MS' sovereignty.

The frequent implementation of this type of reasoning suggests that the concept of sovereignty and the fear of a potential loss or excessive limitation of the MS' sovereign powers are often placed in the center of discussions concerning changes and developments of EU legislation. As will be shown in the follow up, changes of EU law affecting the area of social policy have been also subjected to the same logic.

Among the various examples of this approach, the most indicative and important ones can be derived from constitutional debates surrounding Treaty amendments, which "brought to the fore the national concerns about the impact of European integration on sovereignty and warnings about the constitutional limits to integration" 289 . In particular, the most relevant and prominent examples of applying the sovereignty-related approach can be found in the judgments of MS' constitutional and supreme courts ruling on the compatibility of primary EU law amendments with national constitutional principles, and on the relationship between EU law and national legislation. In those judgments, highest national tribunals have attempted to clarify "the content of delegation of the delimited powers and establish[...] a number of criteria to assess the permissible level of integration, so that sovereignty would not be lost". ${ }^{290}$

\footnotetext{
${ }^{289}$ Anneli Albi and Peter Van Elsuwege, 'The EU constitution, national constitutions and sovereignty: an assessment of a "European constitutional order"' (2004) 29(6) E.L. Rev. 741, p. 742. ${ }^{290}$ Ibid., p. 745.
} 
As described in more detail below, the area of social policy, to which social rights of EU citizens pertain, has been subjected to the same approach. By their insistence on the preservation of the MS' core sovereign powers, including those in the social policy field, national highest tribunals have attempted to define the permissible level of integration in this field and provide guidance for national and European actors responsible for addressing, amongst others, the development of the social dimension of EU citizenship.

Admittedly, the sovereignty-related approach applied by the national highest tribunals and the approach applied by the CJEU in this field have their differences. They concern different types of judicial review, often come at different points in time and address the development of social rights of EU citizens at a different level of abstraction. Unlike the CJEU's case-by-case approach driven by balancing, the sovereignty-related approach is applied mostly in relation to Treaty amendments and in principle around the time when these amendments are made. ${ }^{291}$ Also, unlike the approaches identified at the EU level, the sovereignty-related approach is characterized by a greater degree of abstraction in addressing the development of the social dimension of EU citizenship.

Yet, despite their differences, both lines of approaches can be regarded as

${ }^{291}$ However, different examples can be found at the national level. For instance, the German Federal Constitutional Court has in its Lisbon Treaty judgment examined EU developments in the social policy and EU citizenship field retroactively and its review has clearly gone beyond the Treaty amendments. See the English translation of the case BVerfG, 2 BvE 2/08 vom 30.6.2009, Absatz-Nr. (1 - 421) (German Lisbon Treaty case) is available at

http://www.bundesverfassungsgericht.de/entscheidungen/es20090630_2bve000208 en.html, paras 350 and 399. The Danish Supreme Court, which has exercised its constitutional review years after the ratification of different Treaties, has repeatedly asserted the right and duty of Danish courts to try questions as to whether an(y) act of EU law exceeds the limits for the surrender of sovereignty made by the Act of Accession”. See Carlsen v. Rasmussen (Danish Maastricht case) (1999) 3 C.M.L.R. 854. Also see case No. 199/2012, Judgment of 20 February 2013 (Danish Lisbon Treaty case), available at http://www.domstol.dk/hojesteret/nyheder/ovrigenyheder/Documents/19912engelsk.pdf. These examples demonstrate that, although it is developed mainly in relation to Treaty amendments, the sovereignty-related approach can be applied at different points in time and as an instrument for reviewing not only primary EU law, but all EU legislation. 
determinative for defining the social aspect of EU citizenship. When applied in the field of social rights of EU citizens, these approaches boil down to the same thing. They both comprise attempts to address the existing tensions in the area of social policy, thereby influencing, shaping and directing present and future developments of the social aspect of EU citizenship. Although the sovereignty-related approach is mostly applied in relation to and at the times of Treaty amendments, the actors who employ it tend to look both back and into the future in order to ensure the principle of sovereignty is respected in the process of European integration. Accordingly, its application affects the development of not only primary, but also secondary EU law. For those reasons, the sovereignty-related approach, much like the approach assumed at the EU level, represents a determinative standard in defining the social dimension of EU citizenship. Its contours and, ultimately, its adequacy in this context are thus worth examining.

There are several reasons to focus on the constitutional and supreme courts' case law in identifying the presence and growing popularity of the sovereignty-related approach at the national level. Firstly, the relevance of these decisions derives not only from the fact that they were delivered by the national highest judicial organs which represent the MS, but, more importantly, from the fact that they consist in the interpretation of national constitutional laws, which, to this day, remain crucial in the process of European integration. ${ }^{292}$ Secondly, while it is true that other (mainly political) actors also use the sovereignty-related approach at the national level, limiting the focus of the analysis to highest national tribunals makes sense since these judicial actors act as the ultimate guardians of the constitutional principle of sovereignty in their respective jurisdictions, thus determining its relevance and role in the broader EU context. In that regard, their position is decisive in forming future trends, establishing patterns of behavior and determining attitudes of all other political and judicial actors towards the issue of sovereignty and its impact on future dynamics of the European integration. Therefore, in order to disclose the ongoing tendency of relying on the sovereignty-related approach at the national level, the following subsection will be devoted to the analysis of the mentioned line of case law of highest national tribunals.

\footnotetext{
292 See Monica Claes, 'The Europeanization of National Constitutions in the Constitutionalisation of Europe: Some Observations Against the Background of the Constitutional Experience of the EU-15' (2007) 3 CYELP 1.
} 
Before engaging in this analysis, however, it should be noted that legal authors have so far distinguished between legal and political conceptions of sovereignty. ${ }^{293}$ As MacCormick has rightly observed, whereas these two can be and, in fact, are held to be conceptually distinct, there is an inevitable area of overlap between them. ${ }^{294}$ While acknowledging the 'janus-faced' character of the notion 'sovereignty', as well as the existence of an area of overlap as described by MacCormick, I will attempt to uncover how the MS' highest tribunals understood and employed this notion and particularly its legal meaning when dealing with primary EU law amendments. Such an approach is required by the fact that the intended focus of this research is legal, rather then political.

\subsubsection{Examples of the sovereignty-related approach at the national constitutional level}

The first occurrences of the sovereignty-related approach before highest national tribunals have emerged as a consequence of constitutional reviews of primary EU law changes introduced by the Single European Act and, subsequently, the Treaty of Maastricht.295 In assessing whether these amendments comply with national constitutional norms, several MS'

\footnotetext{
${ }^{293}$ See, for example, Albert Venn Dicey, Introduction to the Study of the Law of the Constitution (Liberty Fund, Indianapolis 1982), pp. 27-29 and Neil MacCormick, 'Beyond the Sovereign State' (1993) 56(1) MLR 1, pp. 11-12.

294 See ibid.

${ }^{295}$ It should be mentioned, however, that when it comes to constitutional courts' judgments not explicitly dealing with the constitutional review of Treaty amendments, one can find even earlier examples of national constitutional courts' usage of the sovereignty-related approach. One such example worth mentioning is the Frontini case decided by the Constitutional Court of Italy in the early 1973 . For an English translation, see Frontini v. Ministero delle Finanze, Case 183 (1974) 2 C.M.L.R. 372. In this decision, it was affirmed that the limitations of sovereignty are constitutionally permissible to the extent that they are necessary for an arrangement that may ensure peace and justice between nations, such as the European integration (para 7 of the Frontini case). However, the Court has also clearly set some boundaries to the transfer and limitations of sovereign state powers. It ruled that limitations of sovereignty are allowed only as long as they do not violate the fundamental principles of the Italian constitutional order or the inalienable rights of man (para 21). In that regard, the Constitutional Court further declared that it would continue to review the compatibility of Treaty amendments with the fundamental constitutional principles, in order to ensure that this requirement is met (para 21).
} 
constitutional and supreme courts have resorted to an approach which puts an emphasis on the preservation of state's core sovereign powers and, consequently, sets limits on further developments of EU law. Thus, a trend was established of resorting to the sovereignty-related approach when new changes of primary EU law come at the table as an object of scrutiny under national constitutional norms and principles. This trend was later followed not only by the courts that originally initiated it, but also by other Member States' highest judicial organs in the course of assessing the compatibility of subsequent Treaty amendments with their national constitutional orders.

The following subsection will be devoted to the analysis of MS' constitutional and supreme courts' decisions that have, so far, dealt with the question of constitutionality of primary EU law amendments. The ultimate goal of this analysis is to extract the relevant parts of those decisions, so as to identify the origins and the main contours of the sovereignty-related approach. In order to better depict its chronological development and its popularity, the analysis will start with the relevant decisions of the pioneers of this approach, namely the Irish Supreme Court, the French Constitutional Council and the German Federal Constitutional Court, followed by the Danish Supreme Court. Besides examining their groundbreaking judgments, the analysis will also cover their more recent decisions, including those on the Lisbon Treaty, in order to provide evidence of the evolving nature and the continuing popularity of the sovereignty-related approach before the highest national tribunals.

As far as more recent case law is concerned, the analysis will also cover the Spanish Constitutional Court's decision on the Treaty establishing a Constitution for Europe, as well as the Lisbon Treaty judgments of the Czech Constitutional Court, the Latvian Constitutional Court, the Hungarian Constitutional Court and the Polish Constitutional Tribunal. In the course of examining the Czech Lisbon Treaty case, a mention will also be made of the decision of the Polish Constitutional Tribunal on the constitutionality of Poland's accession to the EU, as this was one of the decisions explicitly invoked by the Czech Constitutional Court when applying the sovereigntyrelated approach.

From the nine courts that have so far dealt with the constitutionality of Treaty amendments, the one responsible for providing us with the very first example of the application of the sovereignty-related approach is the Irish Supreme 
Court, in its landmark judgment Crotty v. An Taoiseach ${ }^{296}$. In this decision, the Irish Court has reviewed the Single European Act and the compatibility of its ratification with the basic constitutional principles of Ireland.

The Court found that a ratification of the Single European Act ('SEA') would amount to an unconstitutional delegation of state sovereignty. In elaborating its reasoning, it put an emphasis on Article 5 of the Irish Constitution, which provides that Ireland is a sovereign, independent and democratic state. According to the Court, both the Government and the Parliament have a duty to respect this basic constitutional guarantee when they exercise their powers. This means that is not within their competence to free themselves from these constitutional restraints or to transfer their powers to other bodies, unless expressly empowered to do so by the Constitution. ${ }^{297}$ Only the people, who are the guardians of the Constitution, can decide by means of a constitutional amendment to qualify, curtail or inhibit the existing sovereign powers. ${ }^{298}$

Put simply, ratifying acts that surrender a part of state sovereignty would be considered as constitutionally impermissible, making a prior revision of the Constitution a necessary prerequisite for their ratification.

As far as the SEA is concerned, the Court found that its Part III implies a surrender of a part of state sovereignty. ${ }^{299}$ Thus, any attempt by the

${ }^{296}$ Crotty v. An Taoiseach [1987] IESC 4; [1987] IR 713 (9th April, 1987), available at http://www.bailii.org/ie/cases/IESC/1987/4.html.

297 See para 47, the judgment of Judge Walsh, forming part of the majority opinion. Also see para 76, the judgment of Judge Henchy, forming part of the majority opinion.

${ }^{298}$ Para 62, the judgment of Walsh J. Amendments of the Irish Constitution are done by means of referendum. Specifically, Article 46(2) of the Irish Constitution provides that: "Every proposal for an amendment of this Constitution shall be initiated in Dáil Éireann as a Bill, and shall upon having been passed or deemed to have been passed by both Houses of the Oireachtas, be submitted by Referendum to the decision of the people in accordance with the law for the time being in force relating to the Referendum.” As explained by Cahill, "The reason that the people must be consulted when the government wishes to transfer certain of its powers to the European institutions is because [of the understanding that] the powers invested in the government do not belong to the government, but belong rather, in the first instance and in the final analysis, to the people.” Maria Cahill, 'Ireland's Constitutional Amendability and Europe's Constitutional Ambition: the Lisbon Referendum in Context' (2008) 9(10) German Law Journal 1191, p. 1210.

${ }^{299}$ Paras 79, 80, the judgment of Henchy J. 
Government to make a binding commitment this act would be considered as unconstitutional. ${ }^{300}$ The SEA could only be ratified if the Constitution is amended prior to its ratification, so as to allow for such a surrender of sovereign powers. ${ }^{301}$

A similar line of reasoning was adopted by the French Constitutional Council in its decision reviewing the compatibility of the Maastricht Treaty with the basic constitutional principles of the French Republic. ${ }^{302}$ From its very beginning, this decision points to the conclusion that the principle of sovereignty is the primary constitutional value upon which rests the French constitutional review of Treaty amendments. Even its opening paragraphs, devoted to defining the parameters for review provided for by the French Constitution, clearly stress the utmost significance of the principle of national sovereignty, which ultimately belongs to the French people. ${ }^{303}$

Yet, while acknowledging the value of this basic constitutional principle, the ruling explains that it is fully in accordance with the principle of national sovereignty for certain limitations of French sovereign powers to take place.

300 Para 76, the judgment of Henchy J.

301 This has, eventually, led to the amendment of the Irish Constitution, authorizing the ratification of the Single European Act. Concretely, it was the Tenth Amendment of the Constitution Act, 1987, available at

http://www.irishstatutebook.ie/1987/en/act/cam/0010/print.html, that allowed the State to ratify the Single European Act.

302 For an English translation, see Decision 92-308 DC of 9 April 1992, Treaty on

European Union (French Maastricht I case) , available at http://www.conseilconstitutionnel.fr/conseil-constitutionnel/english/case-law/case-law.25743.html. ${ }^{303}$ Ibid., paras 9, 10. In this context, it should be noted that legal theory often differentiates between external and internal sovereignty. The former, also often referred to as national or state sovereignty, is usually understood as a state's power to act independently from external or higher authority. Bruno de Witte, 'Sovereignty and European Integration: The Weight of Legal Tradition' in Anne-Marie Slaughter, Alec Stone Sweet and J.H.H. Weiler (eds), The European Court and National Courts: Doctrine and Jurisprudence (Hart Publishing, Oxford 1998), p. 278, 280. On the other hand, internal sovereignty is usually understood as "the ultimate source of authority within a state”. (Ibid, p. 278.) As de Witte notes, external sovereignty in fact represents a mere reflection of the more deeply-rooted ideological construct of internal sovereignty, which is a central element of the constitutional doctrine of most of the European states. This conclusion also seems to derive from the above-described reasoning of the French Constitutional Council. In the follow up, I will thus focus mainly on what could be understood as different conceptions of internal sovereignty. 
It clarifies that France may, subject to reciprocity, consent to limitations of its sovereignty that are necessary for the organization and preservation of peace. ${ }^{304}$ Accordingly, France may conclude international agreements aimed at participating in the establishment or development of a permanent international organization that enjoys legal personality, as well as decisionmaking powers on the basis of transfers of powers agreed upon by the Member States. ${ }^{305}$ The implicit message standing behind the Constitutional Council's reasoning seems to be that "a State can limit or transfer competences, precisely because it is a sovereign State". 306

However, while recognizing that a transfer of sovereignty may take place, the Constitutional Council has placed an important limitation upon this possibility. It ruled that the international agreements entered into by the authorities of the French Republic can be regarded as permissible only as long as they do not "adversely affect the exercise by the State of the powers that are at the core of its national sovereignty" ${ }^{307}$ If it were to happen that an international agreement involves a clause that conflicts with the French Constitution or jeopardizes the essential conditions for the exercise of national sovereignty, authorization to ratify such an agreement would require a prior revision of the Constitution. ${ }^{308}$

This line of argument was later reaffirmed and further elaborated by the

\footnotetext{
304 Ibid., para 11.

305 Ibid., para 13.

306 Solange Mouthaan, 'France: amending the amended Constitution' (1998) 23(6)

E.L. Rev. 592, p. 596.

307 The French Maastricht I case, para 49. Paragraph 49 of the original French version (available at http://www.conseil-constitutionnel.fr/conseil-

constitutionnel/francais/les-decisions/acces-par-date/decisions-depuis-

1959/1992/92-308-dc/decision-n-92-308-dc-du-09-avril-1992.8798.html) slightly differs from the official English translation cited here. Namely, it begins as follows: "Considérant que les engagements internationaux souscrits par les autorités de la République française ne sauraient affecter l'exercice par l'État de compétences qui relèvent des conditions essentielles de sa souveraineté". (Emphasis added). The language employed in the original French version appears to represent a somewhat stronger account of the identified sovereignty-related rhetoric. The difference in terminology does not, however, exist in relation to paragraph 14 cited below. There, both the French and the English version talk about "the essential conditions for the exercise of national sovereignty", that is, "conditions essentielles d'exercice de la souveraineté nationale".

308 Ibid., para 14.
} 
Constitutional Council in the course of revising the compatibility of subsequent Treaty amendments with the principles of the French Constitution. 309 For example, in reviewing the constitutionality of the Amsterdam Treaty, the Constitutional Council has provided additional guidance as to what kind of transfers might jeopardize the essential conditions for the exercise of national sovereignty. ${ }^{310}$ While following its reasoning from the Maastricht I case, the Constitutional Council has clarified "that in order to decide whether the essential conditions for the exercise of national sovereignty were affected, account had to be taken of: (a) the importance of the matter transferred in the light of the exercise of national sovereignty; (b) the importance of the terms of the transfer: was competence relinquished entirely or was it to be exercised in common; (c) the terms under which these competences were to be exercised by the organs of the European Community and the use of qualified majority voting by the Council" 311 . Thus, while abstaining from a detailed enumeration of powers that lie at the core of the national sovereignty, this ruling has provided the legislature and the executive branch of government with some clarification regarding the exact meaning and the scope of the established sovereignty-related rule.

The latest French example of this kind of constitutional rhetoric can be found in the decision of the Constitutional Council on the Treaty of Lisbon. ${ }^{312}$ In line with its previous case law, this judgment has once again affirmed that EU law provisions adversely affecting the fundamental conditions of the exercise of national sovereignty will be deemed unconstitutional and their ratification will, consequently, require a prior revision of the Constitution. ${ }^{313}$ This has, in turn, provided further evidence of the continuing popularity of the

\footnotetext{
${ }^{309}$ See, for example, the English translations of the Constitutional Council's Decision 97-394 DC of 31 December 1997, Treaty of Amsterdam amending the Treaty on European Union, the Treaties establishing the European Communities and certain related instruments, as well as its Decision 2004-505 DC of November 19th 2004, The Treaty establishing a Constitution for Europe, both available at http://www.conseil-

constitutionnel.fr/conseil-constitutionnel/english/case-law/case-law.25743.html. 310 See Solange Mouthaan, 'France: amending the amended Constitution' (1998) 23(6) E.L. Rev. 592, p. 596.

311 Ibid.

312 For an English translation, see Decision 2007-560 DC of 20 December 2007, Treaty of Lisbon amending the Treaty on European Union and the Treaty establishing the European Community (French Lisbon Treaty case), available at http://www.conseilconstitutionnel.fr/conseil-constitutionnel/english/case-law/case-law.25743.html. 313 See ibid., paras 8 and 9.
} 
sovereignty-related approach in the French constitutional discourse, thereby confirming that sovereignty is far from being regarded as an "outdated concept" 314 .

As mentioned before, several other national highest tibunals have employed a similar approach in the course of assessing the compatibility of primary EU law amendments with their national constitutions. One of the most prominent and controversial examples of this approach can be found in the "Maastricht-Urteil" of the German Federal Constitutional Court. ${ }^{315}$

Applying a similar line of reasoning as the French Constitutional Council, the German Federal Constitutional Court ('the FCC') asserted that it is fully in accordance with the constitutional principle of democracy for the Federal Republic of Germany to become a member of a community of states that acts on its own in sovereign matters and that has the right to exercise independent sovereign powers. 316 According to the FCC, the needed conferring of sovereign powers on such a community of states will necessarily result in the fact that the exercise of these powers will no longer be dependant solely on the will of one Member State. 317

However, in order for membership in such a community of states to take place, certain important preconditions need to be satisfied. Namely, the democratic principle requires that a legitimation and an influence proceeding from the people is secured within such an integration of States. ${ }^{318}$ In the Court's view, this means that the exercise of sovereign powers through a community of States, such as the European Union, needs to be based on prior authorizations from States which even after the accession remain sovereign. ${ }^{319}$

In the event that such an integration and its legislation were developed by the

\footnotetext{
314 John H. Jackson, 'Sovereignty - Modern: A New Approach to an Outdated Concept', (2003) 97 Am. J. Int'l L., 782. Also see Joseph H.H. Weiler, 'Federalism and Constitutionalism: Europe's Sonderweg' Harvard Jean Monnet Working Paper No. 10/00 (2001), p. 8.

315 See Manfred Brunner and Others v. European Union Treaty (German Maastricht case) (1994) 1 C.M.L.R. 57.

316 Ibid., paras 36, 37.

317 Ibid., para 37.

318 Ibid., para 38.

${ }^{319}$ Ibid., para 46.
} 
European institutions in a way that was no longer covered by the initial State's authorization through the Act of Accession, the resultant legislative instruments would, according to the FCC, not be legally binding within the sphere of German sovereignty. ${ }^{320}$ Furthermore, state organs would, for constitutional reasons, be prevented from applying them in Germany. 321 Thus, in order to ensure that European institutions and agencies remain within the limits of the sovereign rights conferred on them, their legal instruments will remain to be subject to the review of the FCC. 322

The Danish Supreme Court in its decision concerning the Maastricht Treaty has assumed a similar approach. ${ }^{323}$ While affirming that a delegation of sovereign powers to the community of states, such as the EU, does not violate the constitutional assumption of a democratic system of government, the Danish Supreme Court ('the DSC') set some boundaries to such transfer of powers. ${ }^{324}$ First, it asserted that a delegation of powers is permissible only in relation to international authorities established by mutual agreement with other states and for the promotion of international rules of law and cooperation. ${ }^{325}$ Second, it ruled that such transfer of powers would be regarded as permissible only so long as it does not affect Denmark's status as an independent state. ${ }^{326}$

The determination of limits of the latter rule must, according to the DSC, rely almost exclusively on considerations of a political nature. ${ }^{327}$ In that regard, the court specified that defining the precise scope and limitations of this rule consists mainly of political decisions, which fall within the wide discretion of the legislative and the executive braches of government. ${ }^{328}$ Yet, the DSC has

\footnotetext{
${ }^{320}$ Ibid., para 49.

${ }^{321}$ Ibid.

322 Ibid.

${ }^{323}$ To be more exact, this decision dealt with the question of constitutionality of the ratification and the incorporation into Danish law of the Maastricht Treaty. See the English annotation by Sten Harck and Henrik Palmer Olsen, 'Decision concerning the Maastricht Treaty.1998 Ugeskrift for Retsvaesen, H 800’ (1999) 93(1) The American Journal of International Law 209.

${ }^{324}$ Ibid., p. 212.

325 Carlsen v. Rasmussen (Danish Maastricht case) (1999) 3 C.M.L.R. 854, para 9.8.

326 Ibid.

327 Ibid.

328 Ibid.
} 
cautioned these branches by reserving a special supervisory role for the judiciary. 329

In order to ensure that the powers conferred on the European institutions are not being transgressed, the DSC has recognized the right and the duty of Danish courts to "try questions as to whether an E.C. act of law exceeds the limits for the surrender of sovereignty made by the Act of Accession" 330 . Accordingly, should the extraordinary situation arise that Danish courts could establish with sufficient certainty that an EU act, upheld by the CJEU or based on the practice of the CJEU, goes beyond the transfer of sovereign powers according to the Act of Accession, such an act would have to be deemed inapplicable in Denmark. ${ }^{331}$ It follows that, while recognizing the CJEU's right to review the validity and legality of EU acts, ${ }^{332}$ the DSC has nonetheless reserved the role of the ultimate guardians of the Danish Constitution for Danish courts. This was recently reaffirmed in the DSC's Lisbon Treaty judgment, which repeated that "it is for the Danish courts to decide whether EU acts exceed the limits for the surrender of sovereignty which has taken place by the Accession Act". 333

All in all, it can be concluded that, by placing the principle of sovereignty in the center of their arguments, the mentioned courts have attempted to define the relationship of EU law and their national legislations, and set firm standards to further development of European integration.

Rather long period of absence of the sovereignty-related rhetoric before the German FCC created the impression that, since its Maastricht judgment, state sovereignty became an outdated concept. However, the FCC's relatively

${ }^{329}$ Ibid. See further Katja Hoegh, 'The Danish Maastricht judgment' (1999) 24(1) E.L. Rev. 80, pp. 84-86.

330 The Danish Maastricht case, para 9.6.

${ }^{331}$ Ibid.. See further Peter Biering, 'The Application of EU law in Denmark: from 1986 to 2000' (2000) 37 CML Rev. 925, pp. 929-931; and Katja Hoegh, 'The Danish Maastricht judgment' (1999) 24(1) E.L. Rev. 80, p. 88-89.

332 Sten Harck and Henrik Palmer Olsen, 'Decision concerning the Maastricht Treaty.1998 Ugeskrift for Retsvaesen, H 800' (1999) 93(1) The American Journal of International Law 209, p. 212.

333 See Section 3 of the Case No. 199/2012, Judgment of 20 February 2013 (Danish

Lisbon Treaty case), available at

http://www.domstol.dk/hojesteret/nyheder/ovrigenyheder/Documents/199-

12engelsk.pdf. 
recent 'Lissabon-Urteil' 334 confirmed that the sovereignty related approach and the resulting 'sovereignty-parlance' are still very much present and popular. In fact, the FCC's heavy reliance on the principle of sovereignty 335 and a further elaboration of the aforementioned sovereignty-related rule in this judgment, seems to indicate that sovereignty is becoming an even more prevalent concept in assessing the acceptability of future developments of EU law. 336

Just as in its Maastricht ruling, the starting point in the FCC's reasoning seems to be grounded in the principle of democracy. However, in comparison with the Maastricht ruling, the FCC's Lisbon Treaty judgment introduces a novelty that aims to add extra weight to this basic constitutional value and provide further arguments in favor of its previously established sovereignty-related approach. In particular, while reaffirming the principle of democracy as an inviolable and a non-amendable principle of the German constitutional law, the FCC's Lisbon Treaty judgment explains that the rights of people to democratic self-determination and democratic participation are anchored in human dignity. 337

According to the FCC, this special nature of the principle of democracy sets an insurmountable boundary to any future political development and, in that respect, not only assumes but guarantees sovereign statehood. ${ }^{338} \mathrm{It}$, therefore,

334 The English translation of the case BVerfG, 2 BvE 2/08 vom 30.6.2009, Absatz-Nr. (1 - 421) (German Lisbon Treaty case) is available at

http://www.bundesverfassungsgericht.de/entscheidungen/es20090630_2bve000208 en.html.

335 It has been noted that "the root "souverän" appears 49 times in the Lisbon decision", which provides "evidence that the language of sovereignty is resurgent in the Court's jurisprudence”. Jo Eric Khushal Murkens, 'Bundesverfassungsgericht (2 BvE 2/08): "We want our identity back" - the revival of national sovereignty in the German Federal Constitutional Court's decision on the Lisbon Treaty' (2010) Public law 530, p. 538.

${ }^{336}$ In that context, some authors have observed that the FCC's main task in the Lisbon Treaty judgment "seems to be the defense of Germany against intrusions by [the Union]”. Therefore, the 'Lissabon-Urteil' seems to additionally stiffen the FCC's "defensive and rather negative attitude towards European integration and the institutions of the European Union”, which was assumed earlier in its Maastricht judgment. Roland Bieber, 'An Association of Sovereign States' (2009) 5 EuConst 391, pp. 396-397.

337 The German Lisbon Treaty case, paras 211, 212, 216.

338 See ibid., para 211, 212 and 216. 
appears that by anchoring the people's right to democratic governance in human dignity, the FCC has attempted to find a more elaborate way to justify its claim to the inalienability of the sovereign statehood. More broadly speaking, the FCC's plan seems to have consisted in coupling the principle of democratic government with the inalienability of the German sovereign statehood and the people's pouvoir constituant, together forming the integral parts of the German constitutional identity, in order to conclude that neither of these may be disposed of by any constitutional body. 339

As previously explained, this does not imply that it would be incompatible with the principle of democracy and sovereign statehood for Germany to join an integration of states such as the EU. On the contrary, it was once again confirmed that the objective of integrating Germany into an international and European peaceful order is fully permissible. ${ }^{340}$ In that context, the FCC has proclaimed not only that the German Basic Law supports Germany's participation in an integration of states such as the EU, but also that it "abandons a high-handed concept of sovereign statehood that is sufficient unto itself" 341 .

Yet, while asserting that the Basic Law provides the legislature with the power to engage in a far-reaching transfer of sovereign powers to the EU, the FCC proclaimed that this power is granted only under the condition that the sovereign statehood is preserved on the basis of an integration program, in accordance with the principle of conferral and with full respect of the MS' constitutional identity. ${ }^{342}$ In this regard, the MS' ability to politically and socially shape the living conditions on their own responsibility should be maintained. ${ }^{343}$ This, according to the FCC, implies that bodies acting on behalf of Germany cannot go as far as to abandon the people's right to selfdetermination and, more generally, Germany's sovereignty by joining a federal state. ${ }^{344}$ Moreover, this implies that German state bodies cannot exercise their right to transfer German sovereign powers in such a way that their exercise can independently establish new competences at the EU level. ${ }^{345}$

\footnotetext{
${ }^{339}$ Dimitrios Doukas, 'The verdict of the German Federal Constitutional Court on the Lisbon Treaty: not guilty, but don't do it again!' (2009) 34(6) E.L. Rev. 866, p. 872.

340 The German Lisbon Treaty case, para 219.

${ }^{341}$ Ibid., para 223.

342 Ibid., para 226.

343 Ibid.

344 Ibid., para 228.

345 Ibid., para 233.
} 
In relation to the principle of sovereignty of the people and the related right of the German people to democratic self-determination, a mention was made specifically of the concept of Union citizenship. In that regard, the FCC found it important to assert that even after the ratification of the Lisbon Treaty, Germany will continue to have "a state people". ${ }^{346}$ Moreover, it added that the Union citizenship is derived from the will of the MS and does not constitute a people of the Union, which would be competent of exercising self-determination as a legal entity capable of giving itself a constitution. ${ }^{347}$ Such a derived status of Union citizenship and the safeguarding of the national citizenship is, in the FCC's view, clearly confirmed by the fact that, in the MS, the right to vote and stand as a candidate in elections above the local level still remains reserved to the MS's own citizens, just as the duty to show financial solidarity in the form of social benefits paid to migrant Union citizens from other MS remains restricted. 348

It follows from the abovementioned that, regardless of the openness towards the European integration and its legal order, German constitutional law supports only those kind of changes in EU law that enable the preservation of the core sovereign powers and respect the MS' constituent power and their deriving status as "the masters of the Treaties" 349 . The FCC has, in this regard, once again asserted the MS' ultimate right to review adherence to the EU integration program, which derives precisely from the continuing sovereignty of the people anchored in the MS and the fact that the MS remain "the masters of the Treaties". 350

In the FCC's view, the requirement to safeguard sovereignty does not in itself imply that a specific number or types of sovereign powers which can be determined from the outset should remain in the hands of the state. ${ }^{351}$ What this means is that the European integration can be realized only in a way that allows the MS to retain a "sufficient space for the political formation of the economic, cultural and social circumstances of life" 352 .

This finding has, in turn, prompted the FCC to define, for the first time,

\footnotetext{
346 Ibid., para 346.

347 Ibid.

348 Ibid., para 350.

349 Ibid., para 235. Also see para 298.

350 Ibid., para 334.

351 The German Lisbon Treaty case, para 248.

352 Ibid., para 249.
} 
which fields of public interest and legislation fall within "the core competences of the state" 353 for the purpose of this rule. In doing so, the FCC has put an emphasis on the area of social policy, describing it as one of the fields that are particularly important for the state's ability to democratically shape itself. ${ }^{354}$ Besides the apparent budgetary concerns and the related issue of "budget sovereignty" in this area, the FCC's also invoked the Germany's devotion to securing the principle of social state and a just social order, in the attempt to justify its reasoning. 355 Moreover, the FCC firmly asserted that the principle of democracy, as well as the principle of subsidiarity require restricting the transfer and exercise of sovereign powers at the Union level in a predictable manner, in particular in "central political areas of the space of personal development and the shaping of the circumstances of life by social policy"356.

According to the FCC, this suggests that, in the mentioned areas, limits of further integration should be drawn "where the coordination of circumstances with a cross-border dimension is factually required" 357 . Consequently, essential decisions in the area of social policy and the securing of the individual's livelihood must remain a primary task of the Member States, which, in the FCC's view, in any event corresponds to the legally and factually limited possibilities of the EU to shape structures of a social state. ${ }^{358}$

It is worth noting that this part of the judgment, identifying the areas of legislation that form the state's "necessary" tasks, represents a real novelty in the German constitutional law. ${ }^{359}$ As noted by Halberstam and Möllers, "for quite a long time a strange commonplace in German constitutional scholarship has been the lack of any Staatsaufgabenlehre, that is, a theory of what necessary tasks the state must fulfill". ${ }^{360}$ By identifying five areas in which the state must take a role, namely, "Criminal law (substantial and procedural), war and peace, public expenditures and taxation, welfare, and

\footnotetext{
${ }^{353}$ Dimitrios Doukas, 'The verdict of the German Federal Constitutional Court on the Lisbon Treaty: not guilty, but don't do it again!' (2009) 34(6) E.L. Rev. 866, p. 882.

354 The German Lisbon Treaty case, para 252.

355 See ibid., paras 249, 251, 252, 256-260.

356 Ibid., para 251.

357 Ibid.

358 Ibid., para 259.

${ }^{359}$ Daniel Halberstam and Christoph Möllers, 'The German Constitutional Court says “Ja zu Deutschland!” (2009) 10(8) German Law Journal 1241, p. 1249.

${ }^{360}$ Ibid., p. 1250.
} 
culture and religion", the FCC's Lisbon Treaty case has suddenly and without precedent developed its own Staatsaufgabenlehre. ${ }^{361}$

This move has, however, been subjected to heavy criticism in academia, predominantly due to the lack of justification surrounding the choice of these supposedly "traditional areas of state regulation". ${ }^{362}$ The main objection, in that regard, concerns the FCC's inability to identify and provide any substantial criteria or theory upon which its list of "necessary" state tasks could have been based. ${ }^{363}$ In particular, it is objected that, rather than providing concrete arguments, the FCC merely asserted that "that "seit jeher," "since ever," the state has fulfilled these tasks as an expression of its sovereignty". 364

According to Halberstam and Möllers, this assertion does not hold water, especially with regards to the area of social policy. They argue that, contrary to the FCC's assertion, "the welfare function of the European nation state has often been described as the beginning of the end of the idea of sovereignty, as the point of dissolution of the state into society". ${ }^{365}$ On the other hand, they rightly question the FCC's omission of some other state functions from the list of the "necessary" ones, such as the area of Civil law and the control over currency, to conclude that from both a historical and systematic perspective, the list makes no sense. ${ }^{366}$ Instead, in their view, "what the Court deems to be protected are merely the leftovers of European integration recycled as necessary elements of state Sovereignty". ${ }^{367}$ According to Halberstam and Möllers, "the deep irony of this part of the decision lies in the fact that the alleged theory of the sovereign state simply stems from a negative reading of the European Treaties". 368

\footnotetext{
361 Ibid.

362 See ibid. Also see Dimitrios Doukas, 'The verdict of the German Federal

Constitutional Court on the Lisbon Treaty: not guilty, but don't do it again!' (2009) 34(6) E.L. Rev. 866.

${ }^{363}$ Daniel Halberstam and Christoph Möllers, 'The German Constitutional Court says “Ja zu Deutschland!” (2009) 10(8) German Law Journal 1241, p. 1250.

364 Ibid.

365 Ibid.

366 Ibid.

367 Ibid., p. 1251.

368 Ibid.
} 
Overall and notwithstanding the described criticism, while still asserting the long-standing principles of the German constitutional law, the German Lisbon Treaty judgment seems to be setting an even stronger trend of relying on the sovereignty-related approach when evaluating constitutionally permissible directions to be taken in the future of the European integration. In addition, the undertaken identification of the 'necessary state tasks' that deserve particular care in terms of preserving state sovereignty, suggests that one of the areas particularly prone to the FCC's constitutional sovereignty-related review is the area of social policy.

Accordingly, the FCC has in its Lisbon Treaty judgment subjected the welfare regulation at the EU level to its constitutional scrutiny. As a result of this exercise, the current level of regulation and development of social issues on the European level was deemed acceptable. In particular, the FCC found that the broad scope of discretion existing at the EU level as regards social issues has not been transgressed, since there are no indications that the MS are deprived of their right, or practical possibilities of action, to take conceptual or other decisions in the area of social policy. ${ }^{369}$ Yet, despite this seemingly positive evaluation of the regulation of welfare issues at the EU level, the

${ }^{369}$ See para 399. One should note, however, the FCC's reasoning is not completely free from ambiguity in relation to this analysis. Namely, there exists a marked ambivalence in the FCC's approach with regards to the regulation of social policy issues at the European level. On the one hand, the FCC recognizes the need for the EU integration to go beyond the purely market-oriented project (para 258, 393), as otherwise "would violate the German constitutional obligation to promote the "social principle” in the EU”. Daniel Halberstam and Christoph Möllers, 'The German Constitutional Court says “Ja zu Deutschland!” (2009) 10(8) German Law Journal 1241, p. 1252. On the other hand, the FCC regards the potential of development of the European social system as even more dangerous (see ibid.), and consequently requires that "the Member States have a sufficient space of competences to take essential social-policy decisions on their own responsibility" (para 393 of the German Lisbon Treaty case). As noted by Halberstam and Möllers "these ambiguities, the juxtaposition of numerous commands pulling in opposite directions, create a doublebind. Whatever Europe does - in whatever way it develops-would seem to violate the standards set forth by the Court. There might be too much, and there might be too little parliamentary legitimacy; too much or too little social standards, and so on. Notwithstanding its grand announcement that the Basic Law has renounced all forms of “political Machiavellianism," the Court turns out to be a wicked strategist itself. Read carefully, its decision condemns the EU to finalité in a state of perpetual deficiency”. Daniel Halberstam and Christoph Möllers, 'The German Constitutional Court says “Ja zu Deutschland!” (2009) 10(8) German Law Journal 1241, p. 1252. 
overall conclusion seems to be that the FCC has significantly limited any further deepening of European integration, by adopting the "hard-line approach to the ultimate question of sovereignty" in its "Lissabon-Urteil". 370

The German Lisbon Treaty case is not the only recent example of the sovereignty-related approach in Europe. In fact, not long before this judgment was delivered, another constitutional court's decision dealing with the review of the Lisbon Treaty amendments confirmed the trend of relying on the previously described sovereignty-related approach. The Czech Constitutional Court's decision on the Treaty of Lisbon ${ }^{371}$ also provided evidence that the principle of sovereignty is the ultimate parameter in reviewing the compatibility of Treaty revisions with national constitutional norms.

Following a similar line of reasoning as the several courts before it, the Czech Constitutional Court ('the CCC') started its Lisbon Treaty ruling by elaborating on the criteria for reviewing the compatibility of the Treaty amendments with the constitutional order of the Czech Republic. It affirmed the principles of democracy and the sovereignty of the people as nonamendable principles forming the material core of the Czech Constitution. ${ }^{372}$

In elaborating the meaning of state sovereignty, the CCC asserted that a transfer of state competences at the EU level does not represent a conceptual weakening of state sovereignty. On the contrary, according to the CCC, it can lead to its strengthening, as long as such transfer of powers is based on the sovereign's free will and conditioned with the sovereign's participation in the integration in a manner that is agreed upon and that is reviewable. ${ }^{373}$ In that regard, the CCC attempted to renounce the traditional understanding of sovereignty, which presupposes independence of the state power from any other power, in both external and internal matters. ${ }^{374}$ It also confirmed that it

\footnotetext{
${ }^{370}$ Dimitrios Doukas, 'The verdict of the German Federal Constitutional Court on the Lisbon Treaty: not guilty, but don't do it again!' (2009) 34(6) E.L. Rev. 866, p. 867. 371 See the English translation of the Czech Constitutional Court's Decision Pl. ÚS 19/08 of 26 November 2008 (Czech Lisbon Treaty case), available at http://angl.concourt.cz/angl_verze/doc/pl-19-08.php.

372 Ibid., para 94.

373 Ibid., para 108.

374 Ibid., para 107. One should note, however, that the CCC's reasoning regarding the meaning of "state sovereignty" is somewhat confusing. Even though the CCC explicitly stated that it has no intention of extensively interpreting the term "sovereign
} 
is fully in accordance with the mentioned constitutional principles for the Czech Republic to join and take part in an integration of states such as the EU, which requires a transfer of certain sovereign powers to supranational institutions.

However, as explained earlier in its Sugar Quota Regulation II case ${ }^{375}$, the transfer of state powers to the EU will be regarded as permissible only so long as these powers are exercised in a way that insures the preservation of the foundations of state sovereignty of the Czech Republic and the essence of the substantive law-based state. ${ }^{376}$ Consequently, should the occasion arise that EU law developments become a threat to the very essence of state sovereignty or the essential attributes of a democratic state governed by the rule of law, it will be necessary to insist that Czech state organs once again take up those powers. ${ }^{377}$

state" in its judgment (para 98), because of, amongst other things, its disputed character and the difficulty of defining this term in the abstract, it has nonetheless engaged in quite an elaborate interpretation of this term in several places. What I find problematic is not the CCC's attempt to clarify the meaning of state sovereignty, despite it's declaration that it has no aim of doing so. What I do find problematic is the confirmation that the meaning of state sovereignty remains disputed and ambiguous, even after the CCC's attempt to clarify it. In that regard, one may note that the CCC fluctuates between the concept of sovereignty of the people (e.g., paras 93, 209), the sovereignty of the Member States (para 102), and, supposedly, in that context, the sovereignty of the Czech Republic as a state (para 209), the concept of pooled sovereignty (para 104) and the concept of practical sovereignty (para 107), making it really difficult for the reader to understand the meaning of sovereignty under the Czech constitutional analysis. The only thing that seems clear is that the CCC is stepping away from the mentioned traditional concept of sovereignty, in order to be able to constitutionally justify the membership of the Czech Republic in the EU. Even though the German FCC did not go into such an extensive, yet unfruitful analysis of the concept of sovereignty, a similar conclusion can be reached in relation to its Lisbon Treaty judgment. While seemingly rejecting the traditional understanding of the term "sovereignty" (see para 223 of the German Lisbon Treaty judgment), the FCC refused to more precisely define the term 'sovereignty', thus, remaining ambiguous as to its meaning.

375 See the English translation of the Czech Constitutional Court's Decision Pl. ÚS 50/04 of 8 March 2006 (Czech Sugar Quota Regulation II case), available at http://angl.concourt.cz/angl_verze/doc/p-50-04.php.

376 Ibid.

377 Ibid. 
In its Lisbon Treaty case, the CCC has once again affirmed and followed this reasoning. ${ }^{378}$ Specifically, it asserted that it is constitutionally impermissible to transfer sovereign state powers "to the effect that it would no longer be possible to speak of the Czech Republic as a sovereign state" 379 . Yet, while confirming that the concept of sovereignty presupposes such a general limitation of the transfer of state competences, the CCC has refused to more precisely define the content and the scope of this limitation. Instead, unlike its German counterpart, it left this task up to the legislature's discretion. ${ }^{380}$ Only to the extent that the scope of the legislature's discretion is exceeded, resulting in an impermissible transfer of sovereign powers, should the Constitutional Court interfere as the ultimate guardian of the Czech constitutional order. ${ }^{381}$

Although not explicitly mentioned by the CCC, the earlier Spanish Constitutional Court's decision on the Treaty establishing a Constitution for Europe applied a very similar approach and rhetoric. ${ }^{382}$ While acknowledging that that the Spanish Constitution allows for the constitutional transfer of powers to the EU to take place, the Spanish Constitutional Court ('the SCC') set some firm limits to such transfer of powers. ${ }^{383}$ Among other things, these limits consist of due respect for the sovereignty of the State. ${ }^{384}$ By applying a similar logic as the several courts mentioned above, the SCC further concluded that in an unlikely event that future evolvements of EU law render it incompatible with the Spanish Constitution, it will be its task to act as the ultimate guardian of the sovereignty of the Spanish people. ${ }^{385}$ On the whole, this ruling can be seen as another attempt to condition future dynamics of the

\footnotetext{
378 See paras 94,113 of the Czech Lisbon Treaty case.

${ }^{379}$ Ibid., para 109.

380 Ibid.

381 Ibid.

${ }^{382}$ For an English translation, see Case 6603-2004 before the Spanish Tribunal

Constitucional (Spanish EU Constitutional Treaty case) (2005) 1 C.M.L.R. 39.

383 Ibid., para 37.

${ }^{384}$ Ibid.

385 Ibid., para 58. That "national sovereignty is vested in the Spanish people" was also affirmed by the Spanish Constitutional Court in its Maastricht case, when the Court was setting the parameters for review of compatibility of the Maastricht Treaty with the Spanish Constitution. See Part II, para 3 of the English translation of the Spanish Constitutional Court's Declaration 1/1991 of 1 July 1992, available at http://www.tribunalconstitucional.es/es/jurisprudencia/restrad/Paginas/DCC11991e n.aspx.
} 
European integration upon the preservation of the core of state sovereignty.

While not using this particular judgment of the SCC as an inspiration in elaborating its rule on the preservation of the essential attributes of sovereignty as "a condicio sine qua non" 386 , the CCC did make explicit reference to some other earlier judgments of national constitutional tribunals. In particular, it openly drew inspiration from the famous German Maastricht case ${ }^{387}$, as well as the Polish decision on the constitutionality of Poland's accession to the EU ${ }^{388}$. In the later case, the Polish Constitutional Tribunal ('the PCT') followed the previously described trend and established a similar sovereignty-related rule under which it is constitutionally impermissible to delegate state competences to the extent that such a delegation would "signify the inability of the Republic of Poland to continue functioning as a sovereign and democratic State". ${ }^{389}$ As described in more detail below, the same rule was applied and further elaborated in the more recent Polish Lisbon Treaty case $^{390}$.

It is important to note here that the CCC was not the only one to make references to other courts' judgments dealing with the question of constitutional permissibility of Treaty amendments. Interestingly, another instance of cross-referencing of that kind can be found in the German Lisbon Treaty case, where a mention was made particularly of the Czech Lisbon Treaty case. ${ }^{391}$ This trend was further followed in the recent Polish Lisbon Treaty case, where the PTC devoted an entire part of its decision to the jurisprudence of

\footnotetext{
386 The Czech Lisbon Treaty case, para 131.

387 See ibid., paras 116, 118.

388 See ibid., para 109.

${ }^{389}$ See para 8 of the English translation of the Polish Constitutional Tribunal's judgment K 18/04 of 11 May 2005, available at http://www.trybunal.gov.pl/eng/summaries/wstep_gb.htm. As far as the understanding of the term sovereignty in Poland is concerned, earlier judgments of the Polish Constitutional Tribunal confirm that Polish Constitution affirms and endorses the principle of sovereignty of the Polish people. See, for example, the English translation of the judgment K 11/03 of 27 May 2003, available at http://www.trybunal.gov.pl/eng/summaries/wstep_gb.htm.

390 See the English translation of the Polish Constitutional Tribunal's judgment $K$ 32/09 of 24 November 2010 (Polish Lisbon Treaty case), available at http://www.trybunal.gov.pl/eng/summaries/wstep_gb.htm.

${ }^{391}$ See para 338 of the German Lisbon Treaty case.
} 
European constitutional courts. ${ }^{392}$ To be exact, in elaborating and applying the sovereignty-related rule, the PCT explicitly drew inspiration from the previously analyzed Lisbon Treaty judgments of the French Constitutional Council, the German Federal Constitutional Court and the Czech Constitutional Court, as well as those of the constitutional courts of Hungary, Latvia and Austria. ${ }^{393}$ All of this indicates that the MS' highest judicial organs tend to keep track and, occasionally, even follow the reasoning of their counterparts in other Member States. These kind of tendency is, in turn, quite indicative in terms of identifying and describing the sovereignty-related approach as an ongoing and growing trend at the national constitutional level.

The Lisbon Treaty saga and the resulting usage of the sovereignty-related approach and rhetoric before national constitutional courts did not end with the discussed Czech and German Lisbon Treaty decisions. The Constitutional Court of Latvia also followed the described trend and provided us with yet another example of reliance on the concept of state sovereignty in reviewing the compatibility of Treaty revisions with national constitutional principles and norms. ${ }^{394}$ Recognizing, amongst others, the principle of democracy and the sovereignty of the State and its people 395 as the fundamental values upon which the State of Latvia is based, the Constitutional Court proclaimed that a delegation of state competences cannot go as far as to violate the basis of an independent, sovereign and democratic state. 396

In affirming the principle of sovereignty as one of the core constitutional principles that the State ought to protect, the Latvian Constitutional Court has, similarly to its Czech counterpart, clarified that the transfer of certain state powers to the EU should be regarded as the exercise of sovereignty of the people, rather then its dilution. ${ }^{397}$ Yet, while accepting that a transfer of sovereign powers actually goes along with the exercise of sovereignty, the Latvian Constitutional Court has nonetheless resorted to the previously described sovereignty-related approach in order to impose certain limitations

\footnotetext{
392 See point 3. of the Polish Lisbon Treaty case, entitled "The Treaty of Lisbon in the jurisprudence of European constitutional courts".

393 See ibid.

394 See the English translation of the Case 2008-35-01 before the Constitutional Court of Latvia (Latvian Lisbon Treaty case) (2010) 1 C.M.L.R. 42.

395 "According to the principle of people's sovereignty, Latvian people are the ultimate bearers of sovereignty”. Ibid., para 173.

396 Ibid., para 207.

${ }^{397}$ Ibid., para 225.
} 
upon such delegation of competences. In that respect, it stated that the transfer of state powers is acceptable only as long as EU law does not violate the principles of a democratic state and the sovereignty of the people. ${ }^{398}$ Accordingly, an unlimited transfer of state powers, which would preclude Latvia from being regarded as a sovereign state, would be strictly deemed as constitutionally impermissible. ${ }^{399}$

A similar rationale was subsequently applied by the Constitutional Court of Hungary in its decision dealing with the issue of conformity of the Lisbon Treaty with the Hungarian Constitution. ${ }^{400}$ While reasserting that it is possible for the holder of sovereignty, that is the Hungarian legislator, to limit the exercise of the attributes of sovereignty, the Court has clarified that such limitations cannot go as far as to deprive the constitutional clauses on sovereignty and rule of law of their substance. 401 Consequently, infringing upon these principles by primary EU law amendments would be strictly considered constitutionally impermissible. ${ }^{402}$ Unlike some of the courts described above, the Hungarian Constitutional Court did not engage in elaborating which fields are reserved for the national legislator and, in that sense, what are the inherent limits of the European integration. ${ }^{403}$

The Polish CT, one the other hand, seemed to have engaged precisely in that kind of exercise in the most recent Lisbon Treaty judgment, simultaneously providing us with the final example of the sovereignty-related approach. While reaffirming the sovereignty-related rule established in its earlier decision on the constitutionality of Poland's accession to the EU, the recent Polish Lisbon Treaty judgment addressed the question of impermissible loss of sovereignty and limits of conferring powers to supranational/international entities in much more detail, describing fairly elaborately the inalienable state competences.

\footnotetext{
398 Ibid., para 224.

399 Ibid., para 225.

400 See the Press Release on the Decision 143/2010. (VII. 14.) AB of the

Constitutional Court of the Republic of Hungary on the constitutionality of the Act of promulgation of the Lisbon Treaty, available at www.mkab.hu/letoltesek/en_0143_2010.pdf.

${ }^{401}$ Ibid.

402 See point 3.6. of the Polish Lisbon Treaty case.

${ }^{403}$ See the Press Release on the Decision 143/2010. (VII. 14.) AB of the

Constitutional Court of the Republic of Hungary on the constitutionality of the Act of promulgation of the Lisbon Treaty, available at http://www.mkab.hu/index.php?id=decisions.
} 
In setting the parameters for review, the PCT first declared that sovereignty could no longer be perceived as an absolute and unrestricted power free from external influences, since the freedom of state activity is now subjected to various restrictions imposed by international law. ${ }^{404}$ According to the PCT, these restrictions are particularly visible in case of the EU legal order, given the binding character of EU law and its direct impact in internal relations between the MS, as well as the broader scope of competences that the Union enjoys in comparison with other international organizations. ${ }^{405}$ However, instead of being regarded as a limitation of state sovereignty, the PCT has argued that the membership in the EU and the incurring obligations should be viewed as a manifestation of state sovereignty. ${ }^{406}$ This, according to the PCT, follows from the fact that the EU membership has allowed the Member States to extend their activities into fields where they had not been present before. 407

Yet, while explaining that states are free to delegate some of their powers to supranational/international bodies and that such a delegation effectively represents a manifestation and not a loss of sovereignty, the PCT clarified that "the principle of protection of state sovereignty in the process of European integration" implies a prohibition of assigning "a universal character" to the conferral of state powers, as well as a complete prohibition of conferral of certain "vital" state competences. ${ }^{408}$

\footnotetext{
${ }^{404}$ See point 2.1. of the Polish Lisbon Treaty case.

405 Ibid.

406 Ibid.

${ }^{407}$ In that regard, the Court has also stressed that the EU membership has not lead to a permanent limitation or loss of sovereign rights of the Member States, given the fact that they have merely assumed an obligation to jointly conduct state duties in areas of cooperation, that the conferral of state competences on the Union is not irrevocable, that the Member States maintain the ultimate competence to "determine competences", as well as the fact that Member States' constitutions, which are the manifestations of state sovereignty, retain their significance. (Ibid.)

408 See point 2.1. and 2.2. of the Polish Lisbon Treaty case. It is interesting to note that this judgment seems to represent the first case in which the sovereignty-related rule was explicitly upgraded to a constitutional principle of its own. This seems to follow from the PCT's recurrent invocation of "the principle of protection of state sovereignty in the process of European integration", which is the kind of terminology that has not yet been used by other national tribunals.
} 
Although admitting that there are difficulties in defining a precise catalogue of inalienable state powers, the PCT has nevertheless attempted to provide a rather exhaustive list of competences that, in its view, constitute the essence of state sovereignty and are, therefore, covered by a complete prohibition of conferral. ${ }^{409}$

According to the PCT, these include "decisions specifying the fundamental principles of the Constitution and decisions concerning the rights of the individual which determine the identity of the state, including, in particular, the requirement of protection of human dignity and constitutional rights, the principle of statehood, the principle of democratic governance, the principle of a state ruled by law, the principle of social justice, the principle of subsidiarity, as well as the requirement of ensuring better implementation of constitutional values and the prohibition to confer the power to amend the Constitution and the competence to determine competences". ${ }_{410}$

While failing to provide any explanation as to why these matters in particular form the essence of sovereignty and are, thus, covered by the complete prohibition of conferral, it is important to notice that the PCT has, similarly to its German counterpart, included decisions concerning the principle of social justice in its list of necessary state tasks. In this way, it seemed to have announced that any social policy decisions at the Union level will be subject to careful scrutiny at the national level, in view of the constitutional requirement to ensure the protection of state sovereignty in the process of European integration. To demonstrate the seriousness of its intentions, the PCT used the Lisbon Treaty ruling itself to engage in a review of compatibility of the EU social goals and values with those of the Republic of Poland, to eventually conclude that they correspond to each other. ${ }^{411}$

All in all, by allowing for the transfer of powers to the EU only insofar as the essence of sovereignty remains untouched, the PCT has affirmed and strengthened the grounds for a strong "sovereignty-based resistance to

\footnotetext{
${ }^{409}$ See point 2.1. of the Polish Lisbon Treaty case. More specifically, the PCT explained that sovereignty of the Republic of Poland implies a "confirmation of the primacy of the Polish Nation to determine its own fate" and is "expressed in the inalienable competences of the organs of the state, constituting the constitutional identity of the state”.

410 See point 2.1. of the Polish Lisbon Treaty case.

411 See point 2.2. of the Polish Lisbon Treaty case.
} 
possible intrusions "from the outside" 412 into the basic guarantees provided for by the Polish Constitution. In doing so, the PCT attempted to reassure anyone fearing possible threats to sovereignty, democracy and the primacy of the Polish Constitution, that it will stand as the ultimate guarantor of constitutional rights enshrined in the Polish Constitution. ${ }^{413}$ More importantly, in doing so, the PCT has attempted to set firm limits to further evolvement of the EU, and EU law as its corollary.

In line with the other discussed cases, the recent Latvian, Hungarian and Polish judgments have, thus, further substantiated the current national constitutional doctrine which rests on the premise that state powers can be transferred to the European Union and its institutions only to the extent that this would not surpass the threshold for preserving the core of state sovereignty. ${ }^{414}$ Contrary to what some may claim, these judgments have provided clear evidence that "to protect national sovereignty" is still very much à la mode. ${ }^{415}$ Moreover, they have confirmed the identified sovereigntyrelated approach as the alpha and omega of the national constitutional review of Treaty amendments, thereby providing us with additional proof that the sovereignty-related approach is a growing trend whose present and potential repercussions should not be underestimated or ignored. 416

412 Wojciech Sadurski, "Solange, chapter 3': Constitutional Courts in Central Europe-Democracy-European Union’ (2008) 14(1) ELJ 1, p. 21.

413 See ibid., p. 19.

414 See further Anneli Albi and Peter Van Elsuwege, 'The EU constitution, national constitutions and sovereignty: an assessment of a "European constitutional order"' (2004) 29(6) E.L. Rev. 741, p. 765.

415 For opposing claims, see Joseph H.H. Weiler, 'Federalism and Constitutionalism: Europe's Sonderweg' Harvard Jean Monnet Working Paper No. 10/00 (2001), p. 8. 416 Admittedly, there are still a number of EU Member States in which the sovereignty-related approach has not been applied by highest national tribunals. The reasons for that are different - either no cases for review of Treaty amendments were yet brought before the competent courts, or there are no courts competent to adjudicate on the constitutionality of (acts ratifying) Treaty amendments, or there is no constitutional guarantee of sovereignty that would facilitate the application of the sovereignty-related approach by the national highest tribunals. The Netherlands is an example of a country which neither has a court competent to review the constitutionality of (acts ratifying) Treaty amendments, nor a constitutional provision affirming the principle of sovereignty. Yet, indicatively enough, even in a country like the Netherlands, the trend of relying on the sovereignty-related rhetoric has spread at the national political level. See, for example, http://www.guardian.co.uk/business/2012/apr/24/eurozone-crisis-dutch-bond- 
These pieces of evidence proving the popularity of the sovereignty-related approach point to another issue of our concern. They suggest that, beyond the need to take a closer look at the potential consequences of this approach, lies the requirement to carefully scrutinize its adequacy in the present European context and, particularly, in the area of social policy. The necessity of putting the described behavior of MS' constitutional actors under scrutiny arises not only from its widespread character, but, more importantly, from the beforementioned decisive role of national constitutional laws in the process of European integration.

\subsection{Conclusion}

The above examples point to the conclusion that the sovereignty-related approach was so far used as the main parameter of national constitutional review of Treaty amendments. In this regard, the analysis shows that there is a strong and growing tendency among crucial judicial actors at the Member States' level of resorting to the sovereignty-related approach when Treaty amendments are being discussed and scrutinized under basic national constitutional principles. Without going into an in-depth analysis of all the subtleties of national constitutional laws and complexities laying behind each particular judgment, this basic overview of the constitutional and supreme courts' decisions has demonstrated the recurrent and popular character of this approach at the national constitutional level.

While leaving aside the question of whether the adopted approach represents the most accurate reading of the MS' constitutional texts ${ }^{417}$, as well as the

auction-government, http://www.spiegel.de/international/europe/left-wing-socialistsare-favorites-in-upcoming-dutch-election-a-852352.html;

http://www.dutchnews.nl/columns/2012/06/ton_van_den_brink_netherlands.php; http://www.nytimes.com/2012/09/14/world/europe/european-union-celebratesgerman-and-dutch-decisions.html?_r=0. For that reason, and in view of the important role of national political actors in shaping of the future of European integration, even in the countries with no courts to apply the sovereignty-related approach or no constitutional provision to ground it upon, the relevance and potential repercussions of this approach should not be underestimated or ignored.

417 This question was addressed, for example, in Dieter Grimm, 'Comments on the German Constitutional Court's Decision on the Lisbon Treaty: Defending Sovereign Statehood against Transforming the European Union into a State' (2009) 5 EuConst 353, pp. 365-367. 
more detailed analysis of possible contradictions in the courts' reasoning ${ }^{418}$, the study of national constitutional decisions has helped uncover the existing general pattern of behavior of MS' constitutional actors, evolving around the concept of sovereignty. As described above, the identified approach basically consists of conditioning future developments of EU law upon the requirement that envisaged legal changes must not adversely affect MS' core sovereign powers.

In addition to providing us with the clear signs of popularity of this approach, the undertaken analysis has also shown that this requirement applies to various areas of public interest, including the area of social policy to which social rights of EU citizens pertain. Overall and despite the perceivable differences in the constitutional courts' findings as to the exact timing of the constitutional review of Treaty amendments, the main actors responsible for such review and the repercussions of potential transgressions of basic national constitutional norms by EU acts, the main message that these courts are sending seems to be that whichever path the European integration takes, it may not go as far as to violate basic sovereign prerogatives of its Member States.

At least three reasons for the widespread character of the sovereignty-related approach come to mind. First, the emphasis put on the preservation of sovereign powers can be explained by the fact that the majority of EU Member States affirm their sovereign statehood through their respective constitutions, thereby highlighting the principle of sovereignty as one of the fundamental values of their national constitutional orders. Namely, of the twenty-six EU Member States with a written constitution ${ }^{419}$, nineteen of them explicitly affirm their sovereignty, usually within the first few articles of their constitutions. ${ }^{420}$ It is therefore not entirely unexpected that, when

\footnotetext{
418 Such as those identified, for example in Daniel Halberstam and Christoph Möllers, 'The German Constitutional Court says “Ja zu Deutschland!”' (2009) 10(8) German Law Journal 1241.

${ }^{419}$ In the absence of the written constitution, the UK is not covered by this analysis. ${ }^{420}$ In terms of explicitly acknowledging its sovereignty, the Maltese constitution seems to represent a borderline case, because the assertions of sovereignty in it are not as plain and obvious as in the other nineteen cases. See Chapter I, Article 1(3)(b) of the Constitution of Malta. In any event, it is interesting to note that of the identified nineteen constitutions that explicitly acknowledge their country's sovereignty, eighteen assert, in more or less similar terms, that sovereignty is vested in the people of their country, thereby affirming the principle of sovereignty of the people or, as
} 
interpreting the primary objects of their concern, constitutional courts tend to rely on sovereignty, the "central and integral concept" 421 of their national constitutions. This becomes even less surprising in the context of a constitutional review concerning permissible transfers of state powers to supranational bodies. ${ }^{422}$

The second reason for the pervasive character and the growing popularity of the sovereignty-related approach amongst highest national tribunals may be found in the emerging constitutional dialogue, taking place at the European level. As visible from some of the judgments listed above, national constitutional and supreme courts clearly tend to observe the behavior of their counterparts in other Member States, occasionally even using foreign courts' decisions as an inspiration and guidance. ${ }^{423}$ Such a tendency of

some call it, the principle of popular sovereignty. The constitution of Cyprus seems to be the only exception in this regard. Of the remaining six constitutions that do not explicitly affirm their country's sovereignty (Austrian, Belgian, Danish, Dutch, German and Swedish), four constitutions (Austrian, Belgian, German and Swedish) seem to implicitly endorse the principle of popular sovereignty. See Chapter 1(A), Article 1 of the Austrian Constitution; Article 33 of the Belgian Constitution; Article 20(2) of the German Basic Law; and Chapter 1, Article 1 of the Swedish Instrument of Government. All in all, it seems to follow that the constitutions of all together twenty-two EU Member States endorse, directly or indirectly, the concept of popular sovereignty. This concrete data, in turn, helps elucidate Albi's and Van Elsuwege's more general assertion that "the cornerstone of national constitutions is the idea that sovereignty is vested in the people”. Anneli Albi and Peter Van Elsuwege, 'The EU constitution, national constitutions and sovereignty: an assessment of a "European constitutional order"' (2004) 29(6) E.L. Rev. 741, p. 743.

${ }^{421}$ Anneli Albi and Peter Van Elsuwege, 'The EU constitution, national constitutions and sovereignty: an assessment of a "European constitutional order"' (2004) 29(6) E.L. Rev. 741, p. 742.

422 The high proportion of 'sovereignty-clauses' in Member States' constitutional texts also explains why examples of the sovereignty-related approach and rhetoric can be found both in the early stages of the European integration, as well as in relation to the recent Treaty amendments. In other words, the great number of national constitutional provisions asserting Member States' sovereignty throughout the entire history of the European integration, seems to clarify why the occasionally dormant sovereignty-related behavior is easily awaken at times when 'new' Treaty amendments came to the table. As seen above, this was best and most recently witnessed during the process of the Lisbon Treaty ratification.

${ }^{423}$ Legal authors have already identified the existence of this trend, not only at the European level, but also on the global level. See, for instance, Anne-Marie Slaughter, 'Judicial Globalization' (1999-2000) 40 Va.J.Int'l L. 1103, p. 1116, who refers to it as 
engaging in transnational judicial dialogue can clearly help explain the increasingly popular character of the sovereignty-related rhetoric at the national constitutional level.

Finally, when discussing national constitutional traditions and the behavior of Member States' constitutional actors, one should not forget the consequences of the last EU enlargements, which caused many Central and Eastern European ('CEE') countries to join the EU. In particular, in relation to the growing popularity of the sovereignty-related approach at the national constitutional level, one should bare in mind that this approach was, and still is, ideally suited to be taken up in those countries. ${ }^{424}$ This derives from the understanding that many of the CEE countries gained back its sovereignty quite recently and not long before they again surrendered a part of it in favor of another "foreign body", that is, the EU.425 Given such state of affairs, sovereignty concerns were felt and expressed quite vigorously during and

"constitutional cross-fertilization" and describes it as the most informal level of transnational judicial contact. Also see Walter Mattli and Anne-Marie Slaughter, 'The Role of National Courts in the Process of European integration: Accounting for Judicial Preferences and Constraints' in The European Court and National Courts, Doctrine and Jurisprudence: Legal Change in Its Social Context (Hart Publishing, Oxford 1998), p. 265; and Monica Claes and Maartje de Visser, 'Are You Networked Yet? On Dialogues in European Judicial Networks', (2012) 8(2) Utrecht Law Review 100. 424 This was argued by Sadurski in a slightly different context (see footnote 425 below). In that regard, he further noted that ignoring this fact could be highly detrimental, as it would entail neglecting "what may become a central stumbling block on the way to the consolidation of the primacy of EU law in an enlarged EU legalpolitical space" and an obstacle in "the alignment of the constitutional orders of the Member States with the EU-wide constitutional order". Wojciech Sadurski, "Solange, chapter 3': Constitutional Courts in Central Europe-Democracy-European Union' (2008) 14(1) ELJ 1, pp. 3, 35.

425 This phenomenon, referred to as "the sovereignty conundrum", as well as its impacts on the political discourses and the public perception of the EU enlargement in CEE countries were more closely described by Wojciech Sadurski. See Wojciech Sadurski, 'Constitutionalization of the EU and the Sovereignty Concerns of the New Accession States: The Role of the Charter of Rights', EUI Working Paper LAW No. 2003/11. Also see Wojciech Sadurski, “Solange, chapter 3': Constitutional Courts in Central Europe-Democracy_European Union' (2008) 14(1) ELJ 1; Anneli Albi, 'Selected EU-Judgments of CEE Constitutional Courts: Lessons on How (not) to Amend the Constitutions?' (2007) 3 CYELP 39, p. 42; and Franz C. Mayer, 'Rashomon in Karlsruhe - A reflection on Democracy and Identity in the European Union', (2011) 9 (3-4) International Journal of Constitutional Law 757, p. 783. 
after the accession in CEE countries, and there was little enthusiasm for a transfer of their recently won powers to the European level. ${ }^{426}$ It is, therefore, not astonishing that a strong determination to protect their core sovereign powers persisted despite the fact that these countries viewed the accession to the EU as one of their basic national strategic goals.

This chain of events and the resulting political and legal reality has, in turn, put constitutional courts of the newly acceded Member States in a situation in which the urge to use the sovereignty-related approach is practically irresistible. ${ }^{427}$ The growing popularity of this approach at the national

426 Wojciech Sadurski, “Solange, chapter 3': Constitutional Courts in Central
Europe-Democracy- European Union' (2008) 14(1) ELJ 1, p. 4, citing Jürgen
Habermas, 'So, Why Does Europe Need a Constitution?' Robert Schuman Centre
Policy Papers, Series on Constitutional Reform of the EU, 2001-02, p. 7.
427 For a similar argument, see Wojciech Sadurski, “Solange, chapter 3':
Constitutional Courts in Central Europe-Democracy-European Union' (2008)

14(1) ELJ 1, p. 4. This argument was made by Sadurski in relation to what he calls "the Solange story". This term stands for the line of reasoning initially developed in the famous German Solange I and Solange II cases decided by the FCC, which was, according to Sadurski, later replicated by several other constitutional courts who were dealing with the question of supremacy of EU law over national constitutional systems and the EU's ability to provide an adequate degree of protection of the principles of the rule of law and human rights. Since Sadurski's term "the Solange story" in part seems to cover what I refer to as the sovereignty-related approach, relying on his argument in the present context seems particularly suitable. Sadurski, however, adds that "the pull towards rephrasing sovereignty-based objections against the supremacy of EU law" was much stronger in the case of constitutional courts of the 'newly' acceded Member States "than in the case of their West European counterparts, which could feel much more relaxed about sovereignty in the EU”. (p. 4) For a similar argument, about constitutional courts of post-communistic Member States being more prone to protect their country's sovereignty in the EU-related context then those of the 'old', Western European Member States, see Jan Komárek, 'European Constitutional Pluralism and the European Arrest Warrant:

Contrapunctual Principles in Disharmony', Jean Monnet Working Paper No 10/05, available at http://www.jeanmonnetprogram.org/papers/05/051001.html. Also see Jakab András, 'Neutralizing the Sovereignty Question: Compromise Strategies in Constitutional Argumentation before European Integration and since' (2006) 2 EuConst, 375, p. 390. Supposedly, these authors would advance the same argument in relation to what I identify as the sovereignty-related approach. However, while such a conclusion may seem plausible at first sight, the national constitutional reality seems to point in a different direction. As demonstrated above by the analysis of constitutional and supreme courts' decisions from both 'new' and 'old' Member 
constitutional level might, thus, be explained by the fact that, after the last enlargements, there are more constitutional courts within the EU that feel bound to protect their countries' sovereignty as the most precious of constitutional values, and are, consequently, inclined to use the 'sovereigntyparlance' in their role of custodians of national constitutional orders.

Yet, while the listed reasons demonstrate the source of the sovereigntyrelated approach and explain its popularity, they hardly prove that this approach is an adequate and a desirable one for assessing the acceptability of developments of EU law in the area of social policy. Since it is fair to assume that at least some of the Member States' constitutional actors will again feel the urge to resort to this increasingly popular way of scrutinizing and conditioning EU law developments, the question of quality and, ultimately, the adequacy of applying the sovereignty-related approach in the context of EU citizens' social rights should not be disregarded.

That is to say, given the clear signs of appreciation for the described sovereignty-related approach shown by the highest national tribunals, it is fair to assume that, without a good reason to stay away from it, at least some of the MS' highest judicial actors will use it again when reviewing the compatibility of EU legislation with their national constitutions. If the logic employed stays the same, and its continuing character shows no signs to the contrary, there is no good reason why prospective developments in the area of social policy and social rights of EU citizens in particular should be exempted from this approach. One might even suggest that, given the accelerated pace of legal developments in this field at the EU level and strong claims to 'welfare sovereignty' at the national level, the area of social rights might get increasingly subjected to the sovereignty-related scrutiny. This claim seems to be supported by the described FCC's reasoning in the recent

States, sovereignty-concerns and the consequent trend of using the sovereigntyrelated approach at the national constitutional level seems to be equally present and popular in both cases. In fact, the recurrent character of the sovereignty-related approach in some of the 'old' Member States that initiated this trend, such as France and Germany, seems to demonstrate that their determination to protect their core sovereign powers persists, if not increases over time. This, in turn, shows that neither constitutional courts in CEE countries, nor those in Western European Member States, feel "relaxed" about their countries' sovereignty in the EU. On the contrary, they both seem to feel equally concerned about this issue. Consequently, the conclusion about constitutional courts in West European countries feeling much more relaxed about sovereignty in the EU does not seem to hold water. 
German Lisbon Treaty case and the PCT's reasoning in the Polish Lisbon Treaty case.

All of this invites us to review the quality, the transparency and, ultimately, the adequacy of applying the sovereignty-related approach in the context of Union citizens' social rights. The invitation to undertake this exercise should be welcomed since, presumably, no one wants to risk undesirable consequences at the European level due to the employment of a potentially inadequate standard at the national constitutional level.

What is decisive, in this respect, is not so much the frequency in using the sovereignty-related approach at the national level. Rather, the crucial factor necessitating the appraisal of its adequacy primarily has to do with who gets to employ the identified rule. As described earlier, the actors who use it mainly consist of national highest tribunals, capable of redirecting evolvements of EU law through an assessment of their compatibility with national constitutionals laws. Therefore, the main reason necessitating a careful evaluation of the sovereignty-related approach lies in the virtually existential influence of the MS' constitutional actors' decisions on the future of the European integration.

It should further be observed that one of the functions of the identified constitutional approach and rhetoric is to set guidance "for those responsible at the national level for the negotiation, conclusion and ratification of the founding, accession and amendment treaties, ie the government, parliament, and possibly also the people in a referendum". ${ }^{428}$ Furthermore, the directions given are also intended for those State organs that participate in decisionmaking at the European level, once the examined Treaty provisions have entered into force. ${ }^{429}$ Finally, the sovereignty-related approach used by MS' constitutional actors is also aimed to act "as a caution to the European institutions in general and to the CJEU in particular". ${ }^{430}$ Given its envisaged functions and its potential influence on all of the mentioned national and European actors, the importance of carefully scrutinizing the adequacy of the

428 This argument was advanced by Monica Claes in a slightly different context, in relation to the national constitutional provisions limiting the transfer of state powers to the EU. Monica Claes, 'The Europeanization of National Constitutions in the Constitutionalisation of Europe: Some Observations Against the Background of the Constitutional Experience of the EU-15' (2007) 3 CYELP 1, p. 32.

429 Ibid.

${ }^{430}$ Ibid. 
identified sovereignty-related behavior becomes even more apparent.

For those reasons, the next chapter will be devoted to a critical analysis of this popular way of addressing EU developments at the national level. Asides from examining the adequacy of applying the sovereignty-related approach in the field of social rights of EU citizens, the following chapter will also engage in a critical assessment of the approaches so far assumed at the Union level in this field. In short, it will be argued that neither the MS' nor the Union actors' approach amounts to an adequate way of addressing the development of this important aspect of European integration. 


\section{Chapter III - Scrutinizing the current ways of addressing EU citizens' social rights developments}

\subsection{Introduction}

Notwithstanding the overall lack of a clear perspective and plan for defining legal contours of the social dimension of Union citizenship, certain strong trends in approaching the development of this aspect of European integration are perceivable at both the national and the supranational level. As shown above, in the EU, there is a tendency of resorting to 'ad hoc political bargains' 431 and a case-by-case approach driven by a continuing balancing exercise between the opposing interests and goals. In the MS, there is a tendency of conditioning developments in EU law, including those in the social rights field, upon the preservation of the core of state sovereignty. These are the current prevalent ways in which the EU and the MS' actors have been addressing tensions inherent to the area of social policy. Ultimately, these are the ways in which relevant actors at both levels of governance have so far approached defining the shape and the content of the social dimension of European citizenship.

Neither of these ways of addressing developments in the social rights field strikes us as particularly surprising. As discussed earlier, the area of social policy is marked by a continuing tension between opposing interests and goals. ${ }^{432}$ On the one hand, there is a goal of promoting the freedom of movement of European citizens across borders and extending solidarity as its corollary. This goal plays in favor of an increase of social rights of EU citizens and a consequent expansion of the concept of Union citizenship. On the other hand, there is an interest in protecting MS' public finances and social security systems, given the MS' continuing role as primary providers of welfare

431 See footnote 23 above, p. 337, 340, 342.

${ }^{432}$ See the Introductory Chapter for a more detailed discussion. 
benefits within the EU. This interest naturally puts breaks on the expansion of the social dimension of Union citizenship.

What 'ad hoc political bargains' and the case-by-case approach driven by balancing merely suggest is that both legislative and judicial actors have, along with the EU as a whole, refused to comprehensively address developments in the social policy field and define a strategy for the evolvement of the social dimension of European citizenship. The CJEU's and the Union legislator's 'give and take' approach described in Chapter I, thus, simply seems to reflect the more far-reaching approach assumed at the EU level, which basically consists in 'resolving' conflicts inherent to this field by leaving them unresolved. The approach applied at the Union level in the area of social rights is, in that regard, quite expected and fully in line with the more general (lack of) strategy for addressing the future of the social aspect of European integration.

As explained in the preceding chapter, the widespread character of the sovereignty-related approach at the MS' level is expected for different reasons. Namely, the ongoing application of this approach in constitutional reviews of primary EU law reflects the importance assigned to the principle of sovereignty by the majority of MS' constitutions. ${ }^{433}$ The appeal to resort to an approach that evolves around the concept of sovereignty, thus, hardly comes as surprise. This is especially so in the context of appraisal of constitutionality of expansions of European integration and consequent limitations of MS' regulatory autonomy. The popularity of this approach in the MS is additionally boosted by the accessions to the EU of a number of excommunist Central and Eastern European countries, which are particularly protective of their sovereign powers given their recent past and heritage. 434 Additionally, the strong pull towards the sovereignty-related approach and its consequent increased application by highest national tribunals derives from

\footnotetext{
433 As described in Chapter II, altogether nineteen EU Member States explicitly affirm sovereignty in their constitutions (usually within the first few articles), thereby highlighting this principle as one of the fundamental values of their national constitutional orders.

434 See further Wojciech Sadurski, "Solange, chapter 3': Constitutional Courts in Central Europe-Democracy — European Union' (2008) 14(1) ELJ 1; and Anneli Albi, 'Selected EU-Judgments of CEE Constitutional Courts: Lessons on How (not) to Amend the Constitutions?' (2007) 3 CYELP 39.
} 
the growing judicial dialogue, taking place in the EU.435

While the listed reasons seem to explain the predictable and recurrent character of these ways of approaching developments of European citizens' social rights, they do not answer the question about the adequacy of their application in the social policy field. Somewhat paradoxically, it seems to be precisely their recurrent and popular character that has lead many to accept these methods without questioning the appropriateness of their application in this context. The question whether these approaches constitute adequate ways of defining the future of the social dimension of EU citizenship, in the absence of a comprehensive agenda for its development, has therefore remained largely unanswered.

This chapter will attempt to comprehensively address this question. The argument will be that the described ways of addressing EU law social rights' developments do not represent adequate methods needed to coherently construct the project of EU citizenship and provide the framework of legitimacy 436 for evolvement of its social dimension. The overarching and shared reason for that is the fact that neither of these approaches, as they currently stand, have the capacity to serve as clear guidance for defining the social aspect of Union citizenship. Specific reasons leading to such incapacity, however, differ in each case. In order to describe them in more detail, the remainder of this chapter will be devoted to the analysis and the identification of problems attached to these current trends in addressing EU citizens' social rights' developments. This kind of analysis should, in turn, provide us with

\footnotetext{
435 As seen in Chapter II, national constitutional courts tend to observe the behavior of their counterparts in other MS, occasionally even using foreign courts' decisions as an inspiration and guidance in elaborating and applying the sovereignty-related approach. For example, the Czech Constitutional Court in its Lisbon Treaty judgment openly drew inspiration not only from the famous German Maastricht case, but also from the Polish decision on the constitutionality of Poland's accession to the EU. Another instance of cross-referencing of that kind can be found in the German Lisbon Treaty case, where a mention was made of the Czech Lisbon Treaty case. This trend was also followed in the recent Polish Lisbon Treaty case, where the Polish Constitutional Tribunal devoted an entire part of its decision to the jurisprudence of European constitutional courts.

436 The framework of legitimacy is here understood as a set of underlying values or principles that can provide the basis for a comprehensive development of social rights in the EU, and define their status and overall placing in the project of European integration. See further, footnote 23 above.
} 
valuable insights needed in order to find more adequate alternatives for addressing the future of the European social dimension.

\subsection{Questioning the adequacy of dominant ways of defining the social dimension of EU citizenship}

\subsubsection{The adequacy of ad hoc political bargaining and a case-by- case approach driven by balancing}

The social aspect of European Union citizenship is admittedly the one that has witnessed the most radical evolvement since the introduction of this concept in the Treaty of Maastricht. ${ }^{437}$ As described in more detail in Chapter I, by a generous interpretation of Treaty provisions, the CJEU has expanded this concept so as to guarantee certain social rights to EU citizens in MS of which they are not nationals. A rule was, thus, developed enabling access to social benefits to EU citizens, provided that they lawfully reside in their host MS and their situations fall within the scope ratione materiae of EU law. ${ }^{438}$ As a result of this initial expansive interpretation of Treaty provisions, noneconomic migrant EU citizens residing in MS of which they are not nationals could now claim equal treatment in access to social benefits on the same terms as nationals of their host MS.

Back when it was first established, this rule seemed rather promising in terms of enhancing social rights and solidarity at the EU level. Its subsequent restrictive interpretation, however, soon made it clear that its benefits for migrant EU citizens are fairly limited in scope and character. More precisely, social rights of non-economic migrants have been gradually circumscribed by means of various conditions and limitations relating both to the lawful residence requirement and the equal treatment guarantee. As a result, and despite the obligation of the MS to comply with general principles of EU

\footnotetext{
437 That is to say, the effects of developments concerning the concept of Union citizenship have been most dramatically felt in the field of social rights, since the citizenship provisions of the Treaty revealed themselves as "notorious catalysts" in expanding social rights of Union citizens, and, particularly, migrant EU citizens who are not economically active. See Koen Lenaerts and Tinne Heremans, 'Contours of a European Social Union in the Case-Law of the European Court of Justice' (2006) 2 EuConst 101, p. 103. Also see Damian Chalmers and others, European Union Law: Text and Materials (CUP, Cambridge 2006), p. 597. 438 Case C-85/96 Martínez Sala [1998] ECR I-2691.
} 
law 439 in the application of measures limiting access to social rights of Union citizens, the overall impression seems to be that social rights and solidarity were not significantly increased at the EU level. Despite the initial expansion of the concept of EU citizenship in the social rights field, the actual significance of this development thus remains fairly limited and somewhat unclear $^{440}$.

The aforementioned ad hoc political bargaining and the case-by-case approach driven by balancing, so far employed by EU actors in their attempts to interpret and define the social dimension of Union citizenship, is mainly what lead to such a state of affairs. In the absence of a clear agenda or guiding criteria provided at the EU level ${ }^{441}$, the area of citizens' social rights thus remained marked by a continuous and unresolved conflict between the goal of realizing the free movement of persons within the Union and promoting social solidarity as its corollary, and that of safeguarding the MS' social security systems and, generally, public purses.

Some might argue that, given the nature of the social policy field, this perpetual and intrinsic conflict of goals needs or asks for no final resolution. Accordingly, engaging in the eternal process of balancing and striking random bargains represents exactly the kind of approach that is suitable in this area. From that perspective, the witnessed reluctance of both the CJEU and the Union legislator to ever give a clear priority to either of the opposing interests and goals is not only expected, but also a desirable way of addressing open issues in the field of social rights.

It is true that the mentioned conflict of goals is inherently tied to the social policy field, at least at the present stage of development of European integration. It does not automatically follow from that, however, that the currently assumed approaches at the EU level are suitable for defining the social dimension of the concept of European citizenship. On the contrary, addressing this conflict of interests and goals on a case-by-case, ad hoc basis, with no clear idea about desired or expected implications of this approach, leads to several serious problems in development of social rights of EU citizens.

\footnotetext{
${ }^{439}$ Mainly, the principle of proportionality.

${ }^{440}$ For a similar argument, see Jo Shaw, 'Citizenship: Contrasting Dynamics at the Interface of Integration and Constitutionalism', EUI Working Paper RSCAS No. 2010/60, pp. 10-13.

441 See further footnote 23 above.
} 
In particular, approaching this aspect of European integration in the described ways shows not only a lack of vision and initiative, but also a clear reluctance to assume any responsibility in development of the social dimension of Union citizenship. The identified 'give and take' approach, whereby the CJEU and the Union legislator have tried to ease the tension between the opposing interests and goals hardly qualifies as an attempt to strike a compromise. Rather, it seems to represents a disguised refusal to face and comprehensively tackle the question about the future of social rights of EU citizens.

Given the fact that the currently assumed methods at the Union level essentially constitute an attempt to avoid any substantial engagement in this area, they have no capacity of serving as a framework of legitimacy or guidance for defining the European social dimension. On the contrary, they can only serve the opposite purpose, for which they seem to be designed: to maintain the indeterminacy in the area and perpetuate vagueness as to exact rights of Union citizens.

While the continued application of these approaches at the Union level may come as no surprise, it is damaging for all parties involved. Namely, the inconsistency and randomness in decision-making leaves both the MS (as primary providers of welfare benefits) and EU citizens (as primary beneficiaries of social rights) in doubt as to what their rights and obligations under EU law are and how they will be interpreted in the future. This indeterminacy is well exemplified not only by a general lack of agenda for developing social rights of EU citizens, but also a number of unresolved issues existing in relation to the already established rule on access of EU citizens to social benefits.

As described in Chapter I, the rule on access of EU citizens to social benefits can be summarized in the terms of a simple formula: EU citizenship plus lawful residence in a host MS plus a situation within the material scope of EU law equals access to Article 18 equal treatment guarantee. Each element of this rule requires additional elaboration. For example, although it is difficult to conceive of any area which is still ratione materiae outside the scope of EU law ${ }^{42}$, it remains to be seen how the material scope of the Treaty will be interpreted in the future for the purpose of this rule. Will the CJEU continue

${ }^{442}$ See footnote 23 above, p. 336. 
to resort to its 'pro-integrative approach'443? Another open question concerns limitations and conditions of Union citizens' residence right. It is not entirely clear which other principles of EU law, aside from the principle of proportionality, do the MS need to comply with in the application of such restrictive measures. ${ }^{444}$ It remains to be seen in this regard whether they also need to comply with fundamental rights, such as for instance the right to family life and, if so, what exactly would this requirement imply.

Additional elaboration is also needed with regards to the scope of application and the exact meaning of the genuine link requirement, which imposes limitations to equal treatment of EU citizens in access to social benefits. It is not entirely clear in this regard whether establishing a degree of connection with the host MS society is to be treated as a means to pursue the legitimate objective of averting unreasonable financial burdens, or as a legitimate objective of its own ${ }^{445}$, and what would be the implications of the latter. In addition, it remains to be seen which other requirements, asides from the usual 'length of residence requirement', and in which cases, should be regarded as suitable for the purpose of establishing a genuine link between a non-economic migrant seeking certain benefits and his/her host MS. Yet another open question in that regard is whether the CJEU's interpretation of the genuine link requirement as a justifiable criterion for unequal treatment that would otherwise amount to direct discrimination should be seen as an isolated case, or could this sort of justification be applied beyond cases covered by Article 24(2) of the Citizens' Rights Directive.

Due to the witnessed incoherence and arbitrariness in developing the social aspect of EU citizenship, it is practically impossible to predict answers to these questions. ${ }^{446}$ The uncertainty as to how these issues might be resolved in the future is even grater given the perceived intransparent character of the CJEU's decisions on citizens' social rights. In particular, the identified lack of

\footnotetext{
${ }^{443}$ As described in more detail in Chapter I, this approach has so far consisted in extending the material Treaty scope so as to enable access to certain social benefits to those categories of persons who were previously kept out of it.

${ }^{444}$ See footnotes 178 and 179 , Chapter I.

445 See footnote 253, Chapter I.

446 See Jo Shaw, 'Citizenship: Contrasting Dynamics at the Interface of Integration and Constitutionalism', EUI Working Paper RSCAS No. 2010/60; and Hadas Alexandra Jacobi, 'A Fürstin by Any Other Name? European Citizenship and the Limits of Individual Rights in the E.C.J.' (2011) 17 Colum. J. Eur. L. 643, p. 667.
} 
clarification ${ }^{447}$ or convincing justification ${ }^{448}$ in its rulings has caused doubt as to how decisions were reached in each particular case and what their implications will be for the future course of development of the social dimension of European citizenship. ${ }^{449}$

The chosen approaches based on random political bargaining and a case-bycase approach driven by balancing seem to have largely facilitated the possibility of reaching intransparent or poorly justified decisions. This is due to the fact that randomness and intransparency in decision-making often go hand in hand and feed each other. It is, therefore, rather expected to find those engaging in arbitrary decision-making to simultaneously rely upon unclear or unjustified arguments. ${ }^{450}$ Yet, while this trend may be expected, it is highly undesirable in the context of development of the concept of EU citizenship and its social dimension. By their conscious entry in this vicious circle of incoherence and ambiguity, EU legislative and judicial actors have generated confusion and uncertainty in the field of social rights. Ultimately, they have failed to provide this important aspect of European integration with the needed coherency and legitimacy.

The identified approaches characterized by a lack of vision and guidance, and the resulting arbitrary and vague decision-making, are thus problematic for two major reasons. First, they are unsatisfactory from the relatively shortterm perspective of the parties involved in the process of building the European social dimension, who presumably share the interest in knowing what their rights and obligations under EU law are. ${ }^{451}$ Second, they are

${ }^{447}$ See, in particular, the discussion related to the cases Bidar, Förster and Commission v Austria in Section 2.2.4., Chapter I.

448 See, in particular, the discussion related to the cases Grzelczyk and Bidar in Section 2.2.3., Chapter I.

${ }^{449}$ See, for example, See Catherine Jacqueson, 'Union citizenship and the Court of Justice: something new under the sun? Towards social citizenship' (2002) 27 E.L. Rev. 260; Michael Dougan and Eleanor Spaventa, 'Educating Rudy and the (Non-) English Patient: A Double Bill on Residency Rights under Article 18 EC’ (2003) 28(5) E.L.

Rev. 699.

450 See above footnotes 447 and 448 .

451 This existence of this interest is, for example, confirmed by the opinion of the Committee on the Internal Market and Consumer Protection on 'the EU Citizenship Report 2010: Dismantling the obstacles to EU citizens' rights', available at http://www.europarl.europa.eu/sides/getDoc.do?type=REPORT\&reference=A72012-0047\&language $=\mathrm{EN} \& \operatorname{mode}=\mathrm{XML}$. This Opinion, amongst other things, 
damaging in the long run, from the point of view of ensuring legitimacy of developments in the area of social rights of EU citizens. Those two reasons, in turn, qualify the methods so far assumed at the EU level as lacking and unsuitable for constructing the project of Union citizenship and its social dimension in particular.

\subsubsection{The adequacy of the sovereignty-related approach}

At the EU level, the lack of agenda and clear criteria guiding the evolvement of the European social dimension has lead to arbitrary and incoherent decision-making, marked by continuous balancing between the opposing interests and goals. A different trend of behavior has emerged at the MS' level. This trend, identified in Chapter II on the basis of highest national tribunals' decisions concerning primary EU law amendments, consists of a recurrent reliance upon the so-called sovereignty-related approach whenever Treaty changes are scrutinized under national constitutional principles and norms. In short, this approach amounts to conditioning changes of EU law upon the preservation of the core of MS' sovereignty.

By a frequent application of the sovereignty-related approach, national constitutional and supreme courts have virtually turned the principle of sovereignty into an instrument for dictating the pace of European integration and setting boundaries of further evolvement of EU law. ${ }^{452}$ Such cautious behavior of MS' judicial actors, built around the principle of sovereignty and concerned mainly with potential negative impacts of the European integration process on MS' powers, remains predominant today and covers all the areas of EU law, including the area of social policy. ${ }^{453}$ This is hardly surprising given the fact that among the factors triggering such behavior,

stresses "that mobility of EU citizens could be enhanced by facilitating and providing better information on the use of their social rights in other Member States".

452 Bruno de Witte, 'Sovereignty and European Integration: The Weight of Legal Tradition' in Anne-Marie Slaughter, Alec Stone Sweet and J.H.H. Weiler (eds), The European Court and National Courts: Doctrine and Jurisprudence (Hart Publishing, Oxford 1998), p. 281.

${ }^{453}$ See Dragana Damjanovic and Bruno de Witte, 'Welfare Integration through EU Law: The Overall Picture in the Light of the Lisbon Treaty', EUI Working Paper LAW No. 2008/34, p. 12. As described in Chapter II, this is particularly visible in the recently decided German and Polish Lisbon Treaty cases. 
socio-economic factors play an important, if not predominant role. 454

While abstaining from a more general discussion concerning the acceptability or desirability of the constitutionality review of Treaty amendments by highest national tribunals in the present EU context, ${ }^{455}$ this section will analyze the adequacy of employing the identified sovereignty-related approach as a criterion guiding the future development of the social aspect of Union citizenship. In other words, it will examine whether the so far predominant approach in the MS provides an adequate way of scrutinizing and dictating changes in the fast-evolving area of social rights of EU citizens. As previously indicated, the argument will be that the sovereignty-related approach fails to provide the needed guidance for policy and lawmakers in this area, thus, amounting to an inadequate standard for defining the social aspect of European integration.

At the very beginning, it is worth taking a moment to compare the sovereignty-related approach to those employed at the EU level in the area of Union citizens' social rights. Unlike 'ad hoc political bargains' and the case-bycase approach driven by balancing assumed at the Union level, the sovereignty-related approach at first sight appears as a more coherent and transparent guidance for policy and lawmakers responsible for defining the European social dimension. This derives from the witnessed recurrent application of the formula warranting a preservation of the core of MS' sovereignty, which seemingly translates into a clear message on what this

\footnotetext{
${ }^{454}$ See Wojciech Sadurski, 'Constitutionalization of the EU and the Sovereignty Concerns of the New Accession States: The Role of the Charter of Rights', EUI Working Paper LAW No. 2003/11, p. 16. Specifically, Sadurski explains that socioeconomic factors (a cold calculus of costs and benefits) are far more important then symbolic or emotional sovereignty issues. Sadurski advances this argument in a somewhat different and narrower context, namely, in relation to the occurrence of anti-accession views and the related sovereignty-concerns in CEE countries. Nevertheless, this argument seems to be applicable even in a broader context, covering the sovereignty-related behavior both within and outside CEE countries. This seems to be well exemplified by the German FCC's explicit invocation of budgetary concerns and the related issue of "budget sovereignty" in relation to the area of social policy (para 256 of the German Lisbon Treaty case), in the course of employing the sovereignty-related approach in its Lisbon Treaty judgment. 455 For that discussion see, for example, Julio Baquero Cruz, 'The Legacy of the Maastricht-Urteil and the Pluralist Movement', EUI Working Paper RSCAS No. $2007 / 13$.
} 
approach requires in the social rights field of EU citizenship.

A closer look at the relevant national constitutional and supreme courts' case law, however, reveals that this optimistic account of the sovereignty-related approach hardly represents an accurate one. It shows that this approach is far from clear in terms of providing the guidance needed to direct developments of EU law in the field of social rights. To a large extent, this derives from the fact that the precise meaning of the term sovereignty remains ambiguous and undefined.

In particular, a careful analysis of the previously described national case law shows that MS' highest tribunals have failed to provide a clear definition of 'sovereignty' - the notion upon which they not only extensively rely, but also upon which they seem to base their national constitutional review of primary EU law. Thus, while the form of the sovereignty-related equation appears to be similar across the analyzed jurisdictions, the content of its most relevant part remains largely unknown.

This lack of a clear definition of the term sovereignty in the courts' judgments, in turn, poses great difficulties for those seeking to determine results of the application of the sovereignty-related approach to a particular field of interest. Namely, without knowing the meaning of sovereignty it is extremely hard to predict what affects its core in a negative way and should, thus, be deemed as unacceptable under this rule. The same problem occurs with respect to the analyzed social rights' developments of the concept EU citizenship. That is, without knowing the precise meaning of the term sovereignty, it is impossible to determine with any certainty which of these EU law developments infringe upon the core of MS' sovereignty and should, consequently, be regarded as impermissible.

The failure of highest national tribunals to clearly define the term sovereignty is thus unsatisfactory as it renders the sovereignty-related approach an empty standard of review. 456 As a result, instead of providing guidance, the sovereignty-related approach merely perpetuates uncertainty in the field of

\footnotetext{
456 While this failure is rather disappointing, it is not particularly surprising. As Bruno De Witte noted, courts often use the term sovereignty without defining its precise meaning. See Bruno de Witte, 'Sovereignty and European Integration: The Weight of Legal Tradition' in Anne-Marie Slaughter, Alec Stone Sweet and J.H.H. Weiler (eds), The European Court and National Courts: Doctrine and Jurisprudence (Hart Publishing, Oxford 1998), p. 278.
} 
social rights of EU citizens.

The lack of a serious attempt of national tribunals to define the principle of sovereignty can probably be explained by two reasons. The first reason, explicitly acknowledged by the Czech Constitutional Court, concerns the disputed character of the term sovereignty and the difficulty of defining it in the abstract. ${ }^{457}$ The second reason seems to be implicit in the reasoning of the courts covered by the above analysis. That is, by refraining from providing a clear definition of the term sovereignty, the highest national tribunals have likely attempted to leave themselves more maneuvering space in the future. In other words, by abstaining from an explicit endorsement of one particular concept of sovereignty and an explanation of its exact terms, these courts have provided themselves with an opportunity to resort to different understandings of the principle of sovereignty when future occasions for using the sovereignty-related approach arise. ${ }^{458}$

457 See para 98 of the Czech Lisbon Treaty case. Besides highest national tribunals, legal scholars have also acknowledged the "essentially contested" nature of the concept of sovereignty. Besson in that regard argued that "the concept of sovereignty not only amounts to a complex and normative concept, but also that it is an essentially contestable concept. As such, it is a concept that not only expresses a normative standard and whose conceptions differ from one person to the other, but whose correct application is to create disagreement over its correct application or, in other words, over what the concept is itself." Samantha Besson, 'Sovereignty in Conflict', 8(15) European Integration online Papers (2004), available at http://eiop.or.at/eiop/texte/2004-015.htm, p. 6. Also see Dan Sarooshi, International Organizations and Their Exercise of Sovereign Powers (Oxford Monographs in International Law Series) (OUP 2005) and Hent Kalmo and Quentin Skinner (eds), Sovereignty in Fragments: The Past, Present and Future of a Contested Concept (Cambridge University Press, Cambridge 2010). On the vague and complex character of the notion of sovereignty, also see Anneli Albi and Peter Van Elsuwege, 'The EU constitution, national constitutions and sovereignty: an assessment of a "European constitutional order"' (2004) 29(6) E.L. Rev. 741, pp. 7556; Roland Bieber, 'An Association of Sovereign States' (2009) 5 EuConst 391, p. 399; Alain de Benoist, 'What is Sovereignty?', translated by Julia Kostova from 'Qu'est-ce que la souveraineté?' in (1999) 96 Éléments 24, available at www.alaindebenoist.com/pdf/what_is_sovereignty.pdf, p. 99; Bernd Krehoff, 'Legitimate Political Authority and Sovereignty: Why States Cannot be the Whole Story' (2008) 14 Res Publica 283, pp. 288-9.

458 In this regard, the Czech Lisbon Treaty case seems particularly indicative, given the before mentioned invocation of what seem to be different conceptions of sovereignty. See footnote 374 above. 
The above-mentioned reasons for the courts' failure to clearly define the term sovereignty are in themselves quite indicative in this context. They show that the widely applied and increasingly popular sovereignty-related approach rests on a highly ambiguous and disputed notion, which even highest national tribunals describe as impossible of being comprehensively interpreted and defined in the abstract. Such nature of the term sovereignty, as well as the interpretative freedom that these courts seemed to have intentionally left at their disposal, lead to a conclusion that what we are faced with is a notion extremely susceptible to manipulation, allowing courts to attach almost any meaning to it, depending on the context in which they use it and on the interests they seek to protect. The application of an approach that rest on such a vague and multifaceted term, in turn, gives rise to serious suspicion.

Yet, before dismissing the sovereignty-related approach as inadequate on those grounds, it should be acknowledged that while some of the analyzed national tribunals were completely unwilling to engage in defining the principle sovereignty in their legal systems, others were slightly less reluctant. In several judgments dealing with the constitutional review of primary EU law amendments we, thus, find attempts of some of the national tribunals to clarify the contemporary meaning of the principle of sovereignty in a little more detail than others. ${ }^{459}$

Broadly speaking, the overview of these efforts points to a conclusion that, whereas highest national courts seem to apply the same formula and approach, they may have a different understanding of its main component, the term sovereignty. Moreover, their vague attempts to clarify the meaning of this term seem to indicate not only that different conceptions of sovereignty may apply in different jurisdictions, but also that there may be several different conceptions of sovereignty operating within a single jurisdiction. 460 Additionally, what causes further confusion is the fact that

\footnotetext{
459 As described in more detail below, the most noteworthy examples of those attempts can be found in the Lisbon Treaty judgments of the CCC, the German FCC and the PCT.

${ }^{460}$ An indicative example in this regard is the Czech Lisbon Treaty case, in which the CCC relied on what appear to be different conceptions of sovereignty. To be exact, in addition to the seemingly dominant concept of popular sovereignty, the CCC relied on several other concepts, including the concept of practical sovereignty and the concept of "pooled sovereignty". See footnote 374 above. However, in line with its acknowledgement of the disputed character of the term sovereignty and the difficulty of defining it in the abstract (para 98 of the Czech Lisbon Treaty case), the CCC
} 
some of courts seem to rely on what appear to be different understandings of one single concept of sovereignty. 461

The fact that highest national tribunals endorse and rely upon different conceptions of sovereignty comes as a consequence of the historical development of this notion. Ever since sovereignty was first comprehensively elaborated in theory by Jean Bodin ${ }^{462}$, in his famous Les Six livres de la République dating back to 1576, this concept was further interpreted in both legal and political circles. This resulted in its gradual and likely never-ending evolution, which quite visibly still goes on today. ${ }^{463}$

In Europe, the evolutionary character of the notion of sovereignty is best visible in the constant emergence of its novel understandings, which frequently come as a product of attempts to adapt this notion to the everchanging political and legal reality. As a consequence, ever since the beginning of European integration, one encounters novel concepts such as those of pooled, shared, divided, split or partial sovereignty 464 - all of which

refrained from providing an elaborate description of the exact terms of the mentioned conceptions, consequently, leaving us in doubt as to what exactly sovereignty means and what the sovereignty-related approach warrants.

461 As described in more detail below, the most indicative and important examples, in that regard, can be found in the Czech, Polish and German Lisbon Treaty case, in relation to the concept of popular sovereignty.

462 See Book I, Chapters 8 and 10 in Bodin Jean, On Sovereignty: Four Chapters from the Six Books of the Commonwealth, edited by Julian H. Franklin (CUP, Cambridge 1992). Bodin described sovereignty as an absolute, indivisible and perpetual power of giving law and issuing commands to all in general and to each in particular. This power, according to him, exists "without consent of any other". (Ibid., p. 56).

Moreover, Bodin clarifies that the power of making and repealing law entails all the other rights and prerogatives of sovereignty, such as declaring war and making peace, establishing principal officers of state, judging in last instance, granting pardons and dispensations against the rigor of the law, coining money, fealty and liege homage, and lying taxes on subjects, or exempting some of them. (See Book I, Chapter 10). ${ }^{463}$ See, for example, András Jakab, 'Neutralizing the Sovereignty Question: Compromise Strategies in Constitutional Argumentation before European Integration and since' (2006) 2 EuConst, 375.

464 See Neil Walker, 'Late Sovereignty in the European Union' in Neil Walker (ed), Sovereignty in Transition (Hart Publishing, Oxford 2006), pp. 14-15. Given the perceived downsides of these concepts, some academics have in the European context attempted to introduce other novel concepts such as those of post-sovereignty, late sovereignty (see further ibid. Also see Neil MacCormick, Questioning Sovereignty: 
are aimed at explaining the meaning of sovereignty in the changed circumstances in which the EU Member States now operate. The occasional invocation of such novel conceptions, and the corresponding renouncement of 'traditional' understandings of sovereignty in some of the courts' judgments, thus, comes rather expectedly. ${ }^{465}$

While adapting 'out-dated' concepts to the changing political and legal reality is certainly needed and inevitable, the consequent dynamic evolution of the notion of sovereignty has largely contributed to overall ambiguity and vagueness as to the exact meaning and implications of this concept, recognized as one of the fundamental constitutional principles in most of the European states. Thus, while somewhat predictable, the trend of relying on different conceptions of sovereignty is deeply confusing and can be dangerously misleading when applying the sovereignty-related approach as a criterion for deciding about the future of European integration and its social dimension in particular.

This follows from the fact that relying on different conceptions of sovereignty in the application of the sovereignty-related rule may generate divergent results. While relying on some conceptions might suggest that certain EU law developments infringe upon the core of MS' sovereignty and are thus unacceptable and forever ruled out, relying on others might suggest that they do not negatively affect the core of MS' sovereignty, but instead affirm it. Outcomes of applying the sovereignty-related approach in the field of social rights of EU citizens could thus largely differ depending on the concept of sovereignty endorsed, in turn, leaving all policy and lawmakers in doubt as to what exactly is required under this approach.

Law, State, and Nation in the European Commonwealth (OUP, Oxford 1999)), competitive sovereignty (Miguel Poiares Maduro, 'Contrapunctual Law: Europe's Constitutional Pluralism in Action' in Neil Walker (ed), Sovereignty in Transition (Hart Publishing, Oxford 2006)) and cooperative sovereignty (Samantha Besson, 'Sovereignty in Conflict', 8(15) European Integration online Papers (2004), available at http://eiop.or.at/eiop/texte/2004-015.htm).

465 See, for example, para 104 of the Czech Lisbon Treaty case, where the CCC explicitly invoked the concept of pooled sovereignty. Examples of renouncement of 'traditional' understandings of sovereignty can be found in the Polish Lisbon Treaty case (point 2.1.), the German Lisbon Treaty case (para 223) and the Czech Lisbon Treaty case (para 107). 
The possibility of reaching divergent outcomes when applying the sovereignty-related rule in the field of social rights of EU citizens will be demonstrated in the follow up by relying on two different conceptions of sovereignty. In particular, two different, coexisting understandings of the concept of popular sovereignty will be relied upon when applying the sovereignty-related approach in this field of interest. One is the conception grounded in the right to collective self-determination and the supporting theory of necessary state tasks. The other one is grounded in the right to individual selfdetermination. Those two alternative conceptions of popular sovereignty will be employed not only because they are indicative in terms of proving the possibility of reaching divergent outcomes in the application of the sovereignty-related approach, but also because they represent contemporary interpretations of the most dominant conception of sovereignty in Europe. As such, they are prone to be further elaborated and relied upon in the future, especially since their traces can be found in some of the national highest tribunals' judgments ruling upon the constitutionality of Treaty amendments.

\subsubsection{Different understandings of the notion of sovereignty}

Before turning to the elaboration of two mentioned understandings of popular sovereignty and the implications of their application in the field of EU citizens' social rights, one should take a look at the broader theoretical context surrounding this dominant conception of sovereignty in Europe. This should provide the background needed in order to better comprehend its divergent contemporary interpretations.

To begin with, it is worth noting that the general idea underlying the concept of popular sovereignty is that people represent the ultimate source of political and legal authority within a state territory. In other words, the concept of popular sovereignty is based upon a belief that "all political and legal power ought to rest on the will and consent of those among and over whom power is exercised" ${ }^{466}$. For that reason, this concept is often being referred to as 'the sovereignty of the people'.

466 Neil MacCormick, Questioning Sovereignty: Law, State, and Nation in the European Commonwealth (OUP, Oxford 1999), p. 130. 
Under the influence of contractarian theories ${ }^{467}$ and the $18^{\text {th }}$ century American and French Revolutions, this concept gradually became a dominant one in continental European countries. ${ }^{468}$ This is nowadays confirmed by the fact that of the twenty-six EU Member States with a written constitution, altogether twenty-two of them implicitly or explicitly assert, in more or less similar terms, that sovereignty is vested in the people of their country. 469

In a nutshell, and regardless possible nuances in its interpretation, it can today be concluded that this prevailing conception of sovereignty and all of its

467 Although Thomas Hobbes is famous for his early and elaborate development of the theory of a social contract, it was the subsequent contractarian theories of scholars such as John Locke and Jean-Jacques Rousseau that had the major impact on development of the concept of popular sovereignty. More particularly, it was Rousseau's social contract theory that largely defined the contours of the presently dominant conception of the sovereignty of the people. See Ken Endo, Subsidiarity \& its Enemies: To What Extent Is Sovereignty Contested in the Mixed Commonwealth of Europe?, EUI Working Paper RSC No. 2001/24, p. 5, 27; András Jakab, 'Neutralizing the Sovereignty Question: Compromise Strategies in Constitutional Argumentation before European Integration and since' (2006) 2 EuConst, 375, p. 377. Unlike Hobbes who argued that, by entering society, individuals give up their sovereignty entirely in favor of a prince who then becomes an absolute sovereign, Rousseau's theory claimed that sovereignty ultimately rests with the people.

According to Rousseau, the people as a sovereign retain the ultimate power to impose the laws, while delegating the power to enforce them to the Government/the Prince. The Government, thus, represents merely a minister of the sovereign people, who review its accountability and renew its mandate. See Jean-Jacques Rousseau, The Social Contract and Other Later Political Writings, edited by Victor Gourevitch (CUP, Cambridge 1997), Book III, Chapter I. All in all, opposite to Hobbes' theory under which it could be said that the state "swallows" the people, under Rousseau's social contract theory, the people "swallow" the state through exercise of the general will. Alain de Benoist, 'What is Sovereignty?', translated by Julia Kostova from 'Qu'est-ce que la souveraineté?' in (1999) 96 Éléments 24, available at www.alaindebenoist.com/pdf/what_is_sovereignty.pdf, p. 104. Under the later theory, the notion of the 'sovereignty of the people' thus becomes fully plausible and justified.

468 This is different from the way in which Bodin's original conception has transformed in Britain, where the concept of parliamentary sovereignty was endorsed. See Bruno de Witte, 'Sovereignty and European Integration: The Weight of Legal Tradition' in Anne-Marie Slaughter, Alec Stone Sweet and J.H.H. Weiler (eds), The European Court and National Courts: Doctrine and Jurisprudence (Hart Publishing, Oxford 1998), p. 279.

${ }^{469}$ See footnote 420 above. 
varying applications ultimately belong to the theory of democracy. ${ }^{470}$ What, thus, lies at the core of the principle of popular sovereignty is the affirmation of the right to self-determination and self-governance ${ }^{471}$, exercised through the rights of democratic participation and representation.

It is worth noting in this regard that popular sovereignty does not presuppose or imply the existence of any constitutional or political state organ enjoying either legal or political sovereignty. ${ }^{472}$ On the contrary, it is the absence of the later that "forces us to identify the people as the ultimate possessor of the sovereignty of their state". ${ }^{473}$ Such a conclusion cannot be reached in case of the main 'rival' concept of sovereignty in Europe - the concept of parliamentary sovereignty, or at least its legal conception. Under this principle, which remains dominant in the UK, it is precisely in an institution that sovereignty resides. ${ }^{474}$ As apparent from its very name, the principle of parliamentary sovereignty suggests that Parliament is "the repository of legal sovereignty" 475 . More particularly, it suggests that Parliament, composed of three bodies acting jointly, namely, the monarch, the House of Lords and the House of Commons ${ }^{476}$, possesses a supreme legal power to make or unmake any law. 477

\footnotetext{
${ }^{470}$ Neil MacCormick, Questioning Sovereignty: Law, State, and Nation in the European Commonwealth (OUP, Oxford 1999), p. 130.

${ }^{471}$ Popular sovereignty can in MacCormick's words be described as 'sovereignty as self-determination'. Ibid., p. 134.

472 Ibid., p. 130.
}

${ }^{473}$ Ibid., p. 131. However, as MacCormick further explains, for the people to count as the ultimate possessor of sovereignty, there needs to exist some constitutional grounding.

${ }^{474}$ Bruno de Witte, 'Sovereignty and European Integration: The Weight of Legal Tradition' in Anne-Marie Slaughter, Alec Stone Sweet and J.H.H. Weiler (eds), The European Court and National Courts: Doctrine and Jurisprudence (Hart Publishing, Oxford 1998), p. 279.

475 Neil MacCormick, Questioning Sovereignty: Law, State, and Nation in the European Commonwealth (OUP, Oxford 1999), p. 133.

${ }^{476}$ When acting together, these three bodies are referred to as the 'King in Parliament' (currently, the 'Queen in Parliament'). See Jeffrey Goldsworthy, The Sovereignty of Parliament: History and Philosophy (Clarendon Press, Oxford 1999), p. 9; and Albert Venn Dicey, Introduction to the Study of the Law of the Constitution (Liberty Fund, Indianapolis 1982), p. 3.

${ }^{477} \mathrm{Ibid}$. This principle, further, implies that no person or body has the right to override, hold invalid or set aside the legislation of Parliament. (Ibid., pp. 3,4. Also see, Jeffrey Goldsworthy, The Sovereignty of Parliament: History and Philosophy (Clarendon 
Just as with any other theoretical construct, there are certain disagreements among legal scholars and practitioners as to parliamentary sovereignty's defining features, such as its origins, the exact extent of the permissible legislative self-restraint and the possibilities of expounding this concept in the future. ${ }^{478}$ Yet, irrespective of these differences in interpretation, it can be more or less unequivocally concluded that the orthodox legal understanding of parliamentary sovereignty ${ }^{479}$ suggests that people are not and could not be considered as sovereign. ${ }^{480}$ The people, that is, the electoral body, have only the right to elect the members of Parliament and can, thus, express itself legally through Parliament and in no other manner. ${ }^{481}$

Dicey, however, acknowledges that "the electors are a part of and the predominant part of the politically sovereign power" ${ }^{482}$ Thus, if sovereignty is

Press, Oxford 1999), p. 10.) The only legal limitation of Parliament's legislative power is that "a parliament of today cannot, with legislation, bind a parliament of tomorrow”. (Stone Sweet Alec, 'Constitutional Dialogues in the European Community' in The European Court and National Courts, Doctrine and Jurisprudence: Legal Change in Its Social Context (Hart Publishing, Oxford 1998), p. 316. Also see, for example, Joaquin Varela Suanzes, 'Sovereignty in British Legal Doctrine' (1999) 6(3) MurUEJL, p. 39; and Jeffrey Goldsworthy, The Sovereignty of Parliament: History and Philosophy (Clarendon Press, Oxford 1999), p. 16.) In other words, Parliament must be at liberty to ignore its own previous laws whenever it passes a new one. (Jeffrey Goldsworthy, Parliamentary Sovereignty: Contemporary Debates (Cambridge University Press, Cambridge 2010), p. 289.) This is also known as the doctrine of implied repeal.

478 For an account of these disagreements see Jeffrey Goldsworthy, Parliamentary Sovereignty: Contemporary Debates (Cambridge University Press, Cambridge 2010. Also, see Tina Oršolić, Book Review of Jeffrey Goldsworthy, Parliamentary Sovereignty: Contemporary Debates (Cambridge University Press, Cambridge 2010), (2011) 7 European Constitutional Law Review 336.

${ }^{479}$ Albert Venn Dicey's elaboration of parliamentary sovereignty is frequently perceived as the orthodox understanding of this principle. See Jeffrey Goldsworthy, Parliamentary Sovereignty: Contemporary Debates (Cambridge University Press, Cambridge 2010), p. 288. Also see Kenneth A. Armstrong, 'United Kingdom Divided on Sovereignty?' in Neil Walker (ed), Sovereignty in Transition (Hart Publishing, Oxford 2006).

480 Joaquin Varela Suanzes, 'Sovereignty in British Legal Doctrine' (1999) 6(3) MurUEJL, p. 38.

${ }^{481}$ Ibid. This, consequently, implies that British courts will take no notice of the will of the electorate. See Albert Venn Dicey, Introduction to the Study of the Law of the Constitution (Liberty Fund, Indianapolis 1982), p. 28.

482 Ibid., p. 29. Emphasis added. 
considered strictly as a political, rather then a legal concept, it may be said that the electors, together with the Crown and the Lords, constitute the body in which sovereign power is vested. ${ }^{483}$ In a political sense, the concept of sovereignty under the British legal tradition therefore appears somewhat closer to the basic postulates of the concept of popular sovereignty. ${ }_{4}^{484}$

It is worth noting in this context that, since its early theoretical elaborations, the concept of popular sovereignty has in itself undergone quite an evolution. This has gradually led to its divergent interpretations - some bringing even closer together and others pushing even farther away the 'rival' concepts of popular and parliamentary sovereignty. Two contemporary understandings of the concept of popular sovereignty are particularly noteworthy in this context - the one grounded in the right to collective self-determination, and the other grounded in the right to individual self-determination.

First, there is an understanding of popular sovereignty grounded in the right to collective self-determination and the supporting theory of necessary state tasks. ${ }^{485}$ According to this understanding, popular sovereignty reflects and manifests itself in the right of the people as a collective, as a national political community, to self-determination. This collective right to self-determination is seen as being exercised mainly through democratic representation and participation rights, allowing the people as a whole to voice their political

483 Ibid., p. 27.

484 Dicey himself admits that the legal and the political meaning of the word sovereignty are, in reality, at least equally important. Ibid., p.28. However, he also clearly states that the two conceptions, even though intimately connected, are essentially different and must not be confused. This is precisely the point around which Dicey's criticism of John Austin's theory of sovereignty evolves. See ibid., pp. 26-9. For a more detailed account of Austin's theory of parliamentary sovereignty, see John Austin, The Province of Jurisprudence Determined ( $2^{\text {nd }}$ edn, Burt Franklin, New York 1970), Lecture VI. As far as the discussion in this Chapter is concerned, it is worth noting that the distinction between political and legal conceptions of sovereignty, and the consequent possibility of relying upon either of them in the application of the sovereignty-related approach, seems to add to the overall confusion as to exact consequences of applying this approach in the field of social rights. On distinction between legal and political sovereignty, see further Samantha Besson, 'Sovereignty in Conflict', 8(15) European Integration online Papers (2004), available at http://eiop.or.at/eiop/texte/2004-015.htm, pp. 8-9.

485 Traces of this understanding of popular sovereignty can be found in the Polish and the German Lisbon Treaty case. Also see Jürgen Habermas, The Crisis of the European Union: A Response (Polity Press, Cambridge 2012), pp. 17-18. 
interests and concerns through representative state institutions. It is considered that, by exercising their democratic rights, people authorize representative state organs to protect and advance their self-determinative choices through performance of the so-called necessary state tasks. Performance of these vital functions by state organs is, in turn, regarded as an affirmation of the people's right to self-determination and a consequent confirmation of their sovereign powers.

Despite the fact that the people as a collective are under this conception considered to be the ultimate holders of sovereignty, the focus of normative concern seems to be shifting towards the state, its organs and their regulatory powers. Since sovereign powers of the people are seen as expressed primarily through performance of necessary state tasks by national institutions, what seems to matter under this conception of popular sovereignty, especially in the context of European integration, is the retention of these vital competences in hands of the state. Their transfer to a supranational level would, under this understanding, result in an impermissible limitation or loss of the sovereignty of the people.

In their recent Lisbon Treaty rulings, the Polish and the German constitutional court seem to have relied upon this particular understanding of popular sovereignty. The Polish Constitutional Tribunal explained that sovereignty of the Republic of Poland implies a "confirmation of the primacy of the Polish Nation to determine its own fate" and is "expressed in the inalienable competences of the organs of the state". 486 The German FCC, similarly, elaborated that safeguarding of sovereignty requires restricting the transfer of sovereign powers at the EU level, particularly in central areas that shape the citizens' economic, cultural and social circumstances of life. ${ }^{487}$ This has, in turn, lead these courts to engage in quite a detailed description of what these untransferable, vital state competences entail. 488 Interestingly, both the German and the Polish tribunal qualified the regulatory competence in the social rights field as the one that needs to remain in the hands of the state and its organs. 489

\footnotetext{
486 See point 2.1. of the Polish Lisbon Treaty case.

${ }^{487}$ See paras 248, 249, 251 of the German Lisbon Treaty case.

${ }^{488}$ For a more detailed account of this unprecedented exercise of defining necessary state tasks and the resulting criticism in the academia, see Chapter II, Section 3.2.1. 489 In particular, the Polish Constitutional Tribunal declared that among the matters under the complete prohibition of conferral are decisions specifying the fundamental principle of social justice (see point 2.1. of the Polish Lisbon Treaty case). Similarly, the
} 
Whereas this understanding of popular sovereignty focuses on performance of inalienable, necessary state tasks by state institutions, the second alternative rests on a rather a different set of premises. Under this alternative understanding of popular sovereignty, individuals and their selfdeterminative rights, rather than necessary state tasks, are placed in the center of normative concern. According to this liberal conception, popular sovereignty finds grounding in the right to individual self-determination, which is considered to pertain to the sphere of human dignity and freedom. ${ }^{490}$ More precisely, what stands at the core of the sovereignty of the people under this conception is the ability and right of every individual to freely determine his/her own personal fate. ${ }^{491}$ This ability is considered to be ultimately based upon the basic rights of individuals to human dignity and freedom. By the same token, the rights to democratic representation and participation, enabling individuals to exercise their right to self-determination, are also seen as derivatives of those basic rights. ${ }^{492}$

What thus matters under this conception of popular sovereignty is the protection of rights to individual self-determination, dignity and freedom. Whether these rights are granted and protected at the national or the supranational level seems to make no difference in terms of advancing the sovereignty of the people. Therefore, rather than requiring a retention of certain necessary tasks at the national level, this understanding of popular sovereignty supports regulation of legal issues in any given policy area and at any given level of governance, as long as such regulation advances self-

German FCC has put an emphasis on the principle of social state and a just social order, while proclaiming the area of social policy as one of primary state tasks (see paras 249, 251, 252, 256-260 of the German Lisbon Treaty case).

490 See further Jürgen Habermas, 'Constitutional democracy: a paradoxical union of contradictory principles?' (2001) 29(6) Political Theory 766; and Jürgen Habermas, The Crisis of the European Union: A Response (Polity Press, Cambridge 2012), p. 18. Also see Nico Krisch, Beyond Constitutionalism: The Pluralist Structure of Postnational Law (OUP, Oxford 2010), pp. 92-94, 99, 282.

${ }^{491}$ Consequently, 'the people' are under this conception understood as a selfdetermining community of free and equal citizens, rather then a monolithic collective. See Jürgen Habermas, 'Constitutional democracy: a paradoxical union of contradictory principles?' (2001) 29(6) Political Theory 766, p. 778.

492 As Habermas explains, under this conception, we "conceive democratic selfdetermination as an uncoerced process of ethical-political self-understanding undertaken by a populace accustomed to freedom”. Jürgen Habermas, 'Constitutional democracy: a paradoxical union of contradictory principles?' (2001) 29(6) Political Theory 766, p. 771. 
determinative choices and prerogatives of individuals, and boosts their human dignity and freedom.

Amongst other conceptions of sovereignty, the Czech Constitutional Court in its Lisbon Treaty judgment seemed to have recognized this understanding of popular sovereignty. This follows from its description of human freedom and human dignity as values that form the foundation of a human being's selfdetermination ${ }^{493}$, and in its interpretation of the sovereignty of the people as a mechanism built to protect "inherent, inalienable, non-prescriptible, and non-repealable fundamental rights and freedoms of individuals, equal in dignity and rights". 494

\subsubsection{Testing the application of the sovereignty-related approach}

In the context of application of the sovereignty-related approach to legal changes in the social rights field of EU citizenship, the distinction between the two described understandings of popular sovereignty can be of a crucial significance. This follows from the fact that depending on the conception of sovereignty endorsed, outcomes of applying the sovereignty-related approach could differ dramatically in this field, in turn, warranting divergent results and opposing solidarity claims at the EU level.

The endorsement of the understanding of popular sovereignty grounded in the right to collective self-determination and the related theory of necessary state tasks in the application of the sovereignty-related approach, would seem to suggest that described developments of EU citizens' social rights have resulted in a decrease of MS' sovereign powers. This seems to follow from the fact that the analyzed evolvement of the European social dimension has limited regulatory autonomy and the maneuvering space of state organs in the area of social policy, thus, interfering with the performance of their necessary state tasks.

In particular, by extending access to certain social rights to Union citizens in host MS, EU law has placed upon the MS a requirement to ensure an effective exercise of those rights in their territory. This implies not only the need to adjust existing national legal practices and norms so as to ensure full effectiveness of the analyzed EU social guarantees, but also the related

493 Para 103 of the Czech Lisbon Treaty case.

${ }^{494}$ Para 93 of the Czech Lisbon Treaty case. 
requirement not to enact any new laws that could jeopardize or obstruct the future exercise of EU citizens' social rights. Both of these requirements seem to diminish the operative capacity of national authorities in the social policy field. The existence of these new rules at the EU level, thus, seems to suggest that national institutions are no longer free to do as they please when it comes to regulating access to social benefits of non-economic migrants from other MS in their state territory. Consequently, their free and undisturbed performance of necessary state tasks related to the social policy area seems to be somewhat restricted, thereby leading to a limitation of the sovereignty of the people.

Under this understanding of popular sovereignty and the related necessary state tasks theory, it can thus be concluded that described changes of EU law in the social rights field have most likely lead to a certain loss or limitation of MS' sovereign powers. The fact that states and their organs were provided with several 'defense mechanisms' 495 , which allow them to somewhat limit the extent to which EU citizens can exercise their 'new' social rights, does not seem to detract from this conclusion, given that there has been an overall increase in regulation of social policy at the EU level.

The same conclusion seems to apply in case of the sovereignty-related approach based on the previously described concept of parliamentary sovereignty. Namely, the existence of new rules at the EU level in the field of EU citizens' social rights seemed to have lead to a decrease of parliamentary sovereignty, since national parliaments are no longer entirely free to regulate access to social benefits of non-economic EU migrants. More precisely, what seems to be put in question, especially in view of the principle of primacy of EU law applied in the context of EU citizens' social rights, is the doctrine of implied repeal and the related rule of parliamentary sovereignty providing that no body or person, other then Parliament itself, can override, hold invalid or set aside the legislation of Parliament. ${ }^{496}$ Whether such restrictions of parliaments' discretion come as a consequence or are in compliance with a possible prior or subsequent parliamentary consent does not seem to detract from the conclusion that national legislatures' sovereign powers have in

\footnotetext{
495 See Chapter I for a more detailed analysis of 'defense mechanisms' left at the Member States' disposal and limitations in their application.

496 See Jeffrey Goldsworthy, Parliamentary Sovereignty: Contemporary Debates (Cambridge University Press, Cambridge 2010), p. 288-9.
} 
reality been limited to some degree..$^{497}$

While the rhetoric of the highest national tribunals might have led us to believe that any increase of regulation at the EU level inevitably leads to a certain limitation of MS' sovereignty ${ }^{498}$, regardless of the concept of sovereignty endorsed, the application of the sovereignty-related approach in view of the above described liberal understanding of popular sovereignty seems to prove the contrary. That is, it demonstrates that the enhancement of social rights of EU citizens and the resulting increased regulation of social issues at the EU level can be sometimes seen as an affirmation of people's sovereign powers.

As explained above, this understanding of popular sovereignty finds grounding in the affirmation of the right to individual self-determination, exercised mainly through democratic participation and representation rights. These rights are, in turn, considered to be based upon the basic right to human dignity and freedom. Relying upon these premises in the context of application of the sovereignty-related rule to changes that took place in the social rights' field of EU citizenship would seem to indicate that the expansion of social rights at the EU level can be seen as a both direct and indirect enhancement of the right to individual self-determination, consequently resulting in an affirmation of popular sovereignty.

The reason why, on the one hand, the provision of 'new' social rights to Union citizens can sometimes be seen as a direct enhancement of the people's sovereign powers derives from the fact that the increase of these rights at the EU level effectively results in giving people what they want ${ }^{499}$, thereby

${ }^{497}$ For theories on parliamentary consent to derogations and invalidation of Acts of the British Parliament, see ibid.; Kenneth A. Armstrong, 'United Kingdom - Divided on Sovereignty?' in Neil Walker (ed), Sovereignty in Transition (Hart Publishing, Oxford 2006); and Neil MacCormick, 'Beyond the Sovereign State' (1993) 56(1) MLR 1.

498 Since they frequently conceptualize effects of the European integration process on MS' regulatory powers in negative terms. As seen in Chapter II, while starting their judgments by proclaiming membership in the EU as a manifestation of MS' sovereignty, national highest tribunals regularly end up scrutinizing EU law developments by concentrating only on their potential negative impacts on MS' sovereign powers.

499 The increase of solidarity and, consequently, social rights at the EU level seems to be precisely what people across the Union want. This is witnessed by a number of 
confirming and further enhancing their right to self-determination. In other words, placing individuals' interests in the focus of normative concern ${ }^{500}$, by providing them with social guarantees they desire, results not only in the concrete affirmation and realization of peoples' interests, but, more broadly, in the acknowledgment of their self-determinative choices and prerogatives. Such a "democratic recalibration" 501 of the European integration in the analyzed field of EU citizenship rights can, accordingly, be seen as an affirmation and further enhancement of the sovereignty of the people. Interestingly, such a recalibration was in itself to a significant extent a consequence of "individual actors appealing to democratic principle in exercising discretion in the fulfillment of their professional and institutional roles" 502 .

recent surveys. In particular, the recent Eurobarometer data shows that, according to European citizens, the idea of solidarity takes precedence over all other values and that "a unified social protection system between Member States would be the main factor in reinforcing the sense of being a European citizen”. See the European Parliament Eurobarometer (EB Standard 70) - Autumn 2008 analysis, European Elections 2009, available at ec.europa.eu/public_opinion/archives/ebs/ebs_303_synt_en.pdf. Also see the European Parliament Eurobarometer (EB/EP 77.4) from 20 August 2012, titled 'Two years to go to the 2014 European elections', available at http://www.europarl.europa.eu/aboutparliament/en/00191b53ff/Eurobarometer.ht $\mathrm{ml}$ ?tab=2012_4. The later survey also confirms that that tackling poverty and social exclusion is considered to be the first among the priority policies that Europeans want to see promoted by the European Parliament. Also see European Parliament Eurobarometer (EB/PE 76.3), Parlemeter - November 2011, available at http://www.europarl.europa.eu/pdf/eurobarometre/2012/76_3/eb76_3_synthese_an alytique_en.pdf. Similarly, according to EU citizens' perception of the Europe 2020 strategy, social measures continue to lead the ranking of initiatives which are perceived as the most important. See the Standard Eurobarometer 75 - Spring 2011 analysis, Europe 2020 Report, available at ec.europa.eu/public_opinion/archives/eb/eb75/eb75_eu20_en.pdf and the Standard Eurobarometer 76 - Autumn 2011 analysis, Europe 2020 Report, available at http://ec.europa.eu/public_opinion/archives/eb/eb76/eb76_en.htm.

${ }^{500}$ See Daniel Halberstam, 'The Bride of Messina: Constitutionalism and Democracy in Europe' (2005) 30 EL Rev 755.

${ }^{501}$ See ibid. Also see Julio Baquero Cruz, 'The Legacy of the Maastricht-Urteil and the Pluralist Movement', EUI Working Paper RSCAS No. 2007/13, pp. 17-8.

${ }^{502}$ Daniel Halberstam, 'The Bride of Messina: Constitutionalism and Democracy in Europe' (2005) 30 EL Rev 755, p. 779. 
The fact that interests and self-determinative choices of individuals were ultimately affirmed and protected at the supranational, and not the national level does not in any way negatively affect the conclusion about the overall enhancement of popular sovereignty. Quite the opposite, the fact that the MS' former regulatory monopoly in the social policy field practically disabled the provision of desired social rights and solidarity among EU citizens seems to suggest that the EU provides for an ideal democratic forum for enhancement of the people's self-determinative choices in this field. ${ }^{503}$ This derives particularly from the ability of the European integration process to lift "the individual from the exclusive confines of Member State processes of political decision making", by allowing the shift of focus from policy preferences of state governments to "European citizens as the immediate subjects of normative concern" ${ }^{504}$.

Furthermore, the fact that the argument about the affirmation of peoples' democratic choices and the enhancement of their right to self-determination can also be extended to the EU level, in view of Union citizens' democratic participation and representation rights provided by EU law, does not seem to diminish the positive effects that the enhancement of Union citizens' social rights has had on popular sovereignty within the MS. This derives from the fact that the cornerstone of this understanding of popular sovereignty remains individuals' right to self-determination, whichever level of government is concerned. As such, it allows for considerably more fluidity of sovereign powers between the national and the supra-national level then the described alternative understanding of popular sovereignty and the related theory of necessary state tasks.

On the other hand, the enhancement of social rights of Union citizens can also be seen as an indirect way of boosting peoples' sovereign powers at both the Union and the MS level. Namely, providing citizens with social guarantees seems to constitute one of the fundamental prerequisites for exercising individual self-determination and democratic self-governance. In other words, an efficient exercise of democratic participation and representation rights, and, more broadly, self-determinative choices of

${ }^{503}$ For a similar argument see Jürgen Habermas, The Crisis of the European Union: A Response (Polity Press, Cambridge 2012), pp. 18-19. This is, of course, not to suggest that there is no room for improvement at the EU level in terms of further enhancement of a desired level of social solidarity.

504 Daniel Halberstam, 'The Bride of Messina: Constitutionalism and Democracy in Europe' (2005) 30 EL Rev 755, pp. 785, 788. 
individuals, is highly unlikely if individuals are not provided with social guarantees necessary to ensure their existence and well-being. This derives from the understanding that, for democracy to function, there needs to exist some guarantee of not only civil and political, but also "economic and social rights to each person, to ensure continuing opportunity of participation on fair terms with others" ${ }^{505}$. By ensuring the needed social guarantees, EU law therefore seems to provide the basis for a successful exercise of the right to self-determination and, more generally, popular sovereignty.

All in all, results of the sovereignty-related approach that relies on the understanding of popular sovereignty grounded in the right to individual selfdetermination seem to indicate that the analyzed developments in the field of EU citizenship can be sometimes seen as having a positive effect on sovereign powers of the people across the Union. This is different from results of the application of the sovereignty-related approach based on the understanding of popular sovereignty grounded in the right to collective self-determination and the related necessary state tasks theory. In turn, this points to a conclusion that there exists a strong tension between these different contemporary understandings of popular sovereignty. This tension has a prospect of becoming even greater in situations where state organs exercising necessary state tasks stop acting as people's representatives, and start acting in their own interest.

More importantly, all of this shows that reliance upon different conceptions of sovereignty may lead to divergent results in the application of the sovereignty-related approach in the social rights field of EU citizenship. Depending on whether these results signal a decrease or an affirmation of sovereign powers, the sovereignty-related approach could warrant either an expansion or a limitation of cross-border access to social rights of EU citizens. It could thus generate opposing solidarity claims at the EU level, depending on the conception of sovereignty endorsed in its application.

It should be noted that in addition to the conceptions of sovereignty relied upon here, there exists a number of alternative understandings of the notion of sovereignty. Amongst others, this includes many novel conceptions of

\footnotetext{
505 Neil MacCormick, Questioning Sovereignty: Law, State, and Nation in the European Commonwealth (OUP, Oxford 1999), p. 134. Also see Jürgen Habermas, 'Why Europe Needs a Constitution' (2001) 11 New Left Review 5, p. 6.
} 
sovereignty in Europe ${ }^{506}$, which are increasingly emerging in constitutional theory. Each of them could be equally relied upon when applying the sovereignty-related approach. Such a possibility of endorsing an indefinite number of understandings of the notion of sovereignty would seem to make room for even more divergent results in the application of the sovereigntyrelated approach to changes that took place in the social rights field of EU citizenship. ${ }^{507}$

The enduring multifaceted character of the term sovereignty and the demonstrated likelihood of reaching contradictory results and opposing solidarity claims as a result of the application of the sovereignty-related approach, both seem to reinforce previously expressed doubts about the capability of this approach to serve as a criterion guiding the evolution of the concept of EU citizenship and its social dimension in particular. These findings about the ambiguous nature of the notion of sovereignty and the resulting divergent outcomes of the sovereignty-related rule reveal not only the utterly intransparent and open-ended character of the analyzed approach. They also indicate that this essentially empty standard of review is highly susceptible to manipulation by those who employ it, since its results depend on the understanding of sovereignty they choose and the area of interest to which they apply it. The possibility of tweaking final outcomes of the sovereignty-related approach is further accelerated by a purposeful refusal of crucial MS' judicial actors to define the precise meaning of the term sovereignty. Since it can be used so selectively and self-servingly, the

\footnotetext{
506 Such as those of pooled, shared, divided, split, partial, late, competitive, cooperative sovereignty or post-sovereignty. See above footnote 464 .

${ }^{507}$ As far as divergent results of the sovereignty-related apporach are concerned, it is interesting to note that the Supreme Court of Estonia recently applied the proportionality test when judging on whether Article 4(4) the Treaty establishing the European Stability Mechanism amounts to an unconstitutional infringement of, amongst others, state sovereignty. See the English translation of the Constitutional Judgment No. 3-4-1-6-12, from 12 July 2012, available at http://www.riigikohus.ee/?id=1347\&print=1. Its reasoning suggested that infringements of state sovereignty will be regarded as permissible so long as they are proportionate for the attainement of other significant constitutional objectives. See ibid., Sexction B. and C. If this line of reasoning happened to be applied in the future, in the context of national constitutional reviews of primary EU law amendments, such a proportionality analysis would undoubtedly open the door for even more unpredictable results of the sovereignty-related approach.
} 
sovereignty-related approach indeed represents an excellent example of "organized hypocrisy" 508 . That is to say, this approach is "not only too vague and general to be a helpful decision making tool when deciding $[\ldots]$ on how we should deal with any particular problems which confront us". 509 It is also an approach "ripe for political exploitation" and often used for that exact purpose. .510

On the whole, given its ambiguous character and the consequent susceptibility to manipulation of its final results, the sovereignty-related approach fails to provide a framework of legitimacy and the needed guidance for policy and lawmakers concerned with the future of the social dimension of EU citizenship. As such, it represents an inadequate standard for defining this aspect of European integration. For those reasons and regardless its growing popularity, this approach should be substituted with more adequate alternatives capable of surpassing its identified downsides.

This is not to suggest that the notion of sovereignty, which seems to be strongly linked to national constitutional identity ${ }^{511}$, should be given up in its

508 This terminology is borrowed from Neil Walker, 'Late Sovereignty in the European Union' in Neil Walker (ed), Sovereignty in Transition (Hart Publishing, Oxford 2006), p.17, citing Stephen D. Krasner, Sovereignty, Organized Hypocrisy (Princeton University Press, Princeton 1999).

${ }^{509}$ Konrad Schiemann, 'Sovereignty: A Concept Creating Confusion', available at http://eutopialaw.com/2013/03/11/sovereignty-a-concept-creating-confusion/. Although Schiemann referred to the notion of sovereignty when he argued this, the quotation seems to fit, since his argument can be easily extended to the sovereigntyrelated approach, which rests on this very notion.

${ }^{510}$ Jessica Simor, 'Sovereignty - The historical perspective; or 'les absents ont toujours tort', available at http://eutopialaw.com/2013/03/07/sovereignty-thehistorical-perspective-or-les-absents-ont-toujours-tort/\#more-1809. In fact, Simor referred to sovereignty being a concept ripe for political exploitation. However, her words also seem to provide a good description of the sovereignty-related approach itself - as an approach that puts this concept at its core.

511 On the link between sovereignty and constitutional/national identity see, for example, Bruno de Witte, 'Sovereignty and European Integration: The Weight of Legal Tradition' in Anne-Marie Slaughter, Alec Stone Sweet and J.H.H. Weiler (eds), The European Court and National Courts: Doctrine and Jurisprudence (Hart Publishing, Oxford 1998), p. 300; Jakab András, 'Neutralizing the Sovereignty Question: Compromise Strategies in Constitutional Argumentation before European Integration and since' (2006) 2 EuConst, 375, pp. 390, 395; Miriam Aziz, 
entirety. The appeal to resort to the sovereignty-related rhetoric in public discourse will surely persist given its strong emotional and symbolic overtone. It would be somewhat naïve to expect this to change by any arguments of law or logic.

Yet, when it comes to legislative and judicial actors capable of redirecting the future course of development of the social dimension of EU citizenship, expectations are different. Because of the roles assigned to them by the people they represent and the discursive influence they have, these actors should rely upon transparent and workable standards with meaning and substance. As appealing as the sovereignty-related approach may be, as it now stands, it amounts to an empty standard of review that creates not only confusion as to its exact implications, but also patterns of behavior for all other actors. ${ }^{512}$ For those reasons, the appeal to use this approach as a legal standard for defining EU citizens' social rights developments should be resisted and alternative criteria should be employed instead.

\subsection{Conclusion}

The purpose of this Chapter was to put under scrutiny the current ways of defining social rights of EU citizens and addressing tensions present in the social policy field, at both the MS' and the Union level. It was analyzed whether ad hoc political bargaining and a case-by-case approach driven by balancing, or the sovereignty-related approach constitute adequate ways of constructing the social dimension of EU citizenship, in the absence of a comprehensive agenda for its evolvement. The conclusion reached was that neither of these ways of addressing EU citizens' social rights developments constitutes a satisfactory method of defining the future of this aspect of European integration.

'Sovereignty Lost, Sovereignty Regained? Some Reflections on the Bundesverfassungsgericht's Bananas Judgment', EUI Working Papers RSC No. 2001/31, p. 18, and Franz C. Mayer, 'Rashomon in Karlsruhe - A reflection on Democracy and Identity in the European Union', (2011) 9 (3-4) International Journal of Constitutional Law 757, p. 783. Also see the German Lisbon Treaty case (paras 218, 226, 235) and Polish Lisbon Treaty case (point 2.1.).

512 See, for example, Václav Klaus' speech at the Czech Constitutional Court proceedings on the Lisbon Treaty, from 25 November 2008, available at http://www.klaus.cz/clanky/1277. 
The analysis has helped detect a number of more or less obvious problems and disadvantages attached to these approaches. Random political bargaining and the case-by-case approach driven by balancing, both assumed at the EU level, were revealed as arbitrary and intransparent methods that gradually generated a lack of coherence, legal certainty and legitimacy in the field of social rights of EU citizens. As such, they were characterized as suitable only for perpetuating vagueness and indeterminacy in this field, not for building a framework of legitimacy and providing guidance needed to responsibly construct the project of Union citizenship.

The sovereignty-related approach was proven to be inadequate for different reasons. Given the disputed and open-ended character of the notion it rests upon, this approach exposed itself as an essentially empty standard or review. Moreover, its application in the social policy field has shown that it is highly susceptible to manipulation, depending on the understanding of sovereignty endorsed. As such, this seemingly clear standard of review has proven to provide no comprehensible framework or guidance, thus, amounting to an unsuitable criterion for defining the social aspect of EU citizenship.

It is worth noting that the sovereignty-related approach could be modified so as to surpass its identified downsides and provide clearer guidance to those concerned about the future of the European social dimension. This could be done by means of endorsement and elaboration of a clear concept of sovereignty by reviewing tribunals who employ this approach. In this way, vagueness as to its exact implications and the possibility of tweaking its final outcomes would be considerably reduced, in turn, turning the sovereigntyrelated approach into a more useful guiding criterion in the field of social rights.

An optimal choice in this regard would be the one that comprises the endorsement of a concept of sovereignty capable of transcending old dichotomies between the state and the supranational level ${ }^{513}$, and allowing for a certain fluidity of sovereignty powers between these two levels of governance. In other words, a desirable choice would be the one that moves away from the exclusive interests of the MS and better accommodates the current legal and political reality in the Union marked multi-level governance.

\footnotetext{
513 This terminology is borrowed from Mattias Kumm, 'The Legitimacy of International Law: A Constitutionalist Framework of Analysis' (2004) 15(5) EJIL 907, p. 931.
} 
Such choice could turn the sovereignty-related approach not only into a clearer standard of review, but also in the one tailored both for the MS' and the Union judicial and political actors, consequently, enabling a constructive dialogue between them on the future of the European social dimension.

The prospect of this kind of scenario is, however, highly unlikely. As explained earlier, the historical development of the notion of sovereignty has to this day been marked by a constant emergence of novel concepts of sovereignty and a consequent continuing disagreement as to its exact meaning. The emergence of new understandings of the notion of sovereignty is not by chance and certainly not uncalled for. It serves the purpose of adapting this theoretical construct to the ever-changing political and legal reality. Yet, given the enduring evolutionary character of the notion of sovereignty, it is hard to expect from highest judicial organs to explicitly endorse and clearly elaborate one single conception of sovereignty, with a view of relying upon it on every future occasion.

Even if reviewing tribunals should decide to engage in such an exercise and consciously limit their space for maneuver in the future, it is very unlikely that all the tribunals applying the sovereignty-related approach would endorse and rely on the same conception of sovereignty. Even more unlikely, in this regard, would be a uniform endorsement of a single concept of sovereignty that allows for the mentioned fluidity of sovereign powers and turns its focus away from exclusive interests and regulatory powers of the states.

Given the fact that the adequacy of the analyzed approaches is highly questionable or hardly achievable, the question remains what is to guide the future development of the social dimension of the concept of European citizenship. That is, having in mind the acute and virtually irredeemable weaknesses of the currently employed approaches at the Union and the MS level, which alternative criteria could one turn to in search for the guidance needed in this area? The following chapter will attempt to answer this question. This will be done particularly having in mind the undesirability of maintaining the status quo in the area of social rights, emphasized by Union citizens themselves. ${ }^{514}$ More generally, this will be done in view of the need to provide legitimacy to the project intrinsically tied to that of European integration, the project of Union citizenship.

514 See footnote 499 above and footnote 597 below. 


\section{Chapter IV - In search for an alternative way of constructing the social dimension of EU citizenship}

\subsection{Introduction}

The methods currently assumed in the field of social rights of EU citizens are lacking and unsuitable. In order to supply the project of Union citizenship and its social dimension with the needed muscle and legitimacy, an alternative approach is required. Keeping in mind the fundamental nature of European citizenship and the need to responsibly and coherently address its future construction, this chapter will engage in a search for alternative ways of defining its social aspect. In particular, it will explore and eventually propose an alternative approach for defining the scope and the content of social rights of EU citizens. Before turning to the suggested solution, however, some preliminary observations should be made. They concern general requirements that need to be met in order for any chosen alternative to qualify as truly adequate for defining the social dimension of European Union citizenship.

The first and basic set of requirements comes as a necessary consequence of the conclusions reached in the previous chapter. Whatever the suggested alternative for addressing the development of EU citizens' social rights, in order to qualify as adequate it must be capable of surpassing the downsides of the methods currently employed in this field. To be exact, it must be able to overcome the deficiencies of the previously analyzed ad hoc and case-by-case approach guided by balancing employed at the Union level, and the sovereignty-related approach assumed at the national level. In short, this means that a suggested alternative must comprise a significantly more instructive, coherent and transparent guiding criterion, capable of generating legitimacy and legal certainty in the social rights field of EU citizenship. 
Aside from the need to constitute a standard of assessment that can provide decision-making processes with more coherency, transparency and legitimacy, an alternative approach for building the social dimension of European citizenship should fulfill several other conditions.

Ideally, it should be based upon values recognized and cherished at both the national and the supranational level. Fulfilling this requirement is desirable because it would increase the chances of acceptance of the proposed alternative at both levels of governance. More importantly, endorsement of an approach grounded in mutually accepted values and employable at both levels would provide a platform for cooperation and dialogue regarding the future of the European social dimension, as well as mutual control of relevant national and EU actors. As such, it would represent a useful decision-making tool in the present context of multilevel governance in the EU.

Because it would enable cooperation, dialogue and mutual control of national and EU actors, an approach based upon common values would also be prone to increase the legitimacy of measures defining the concept of Union citizenship, as well as of EU policy and the EU as a whole. This would in turn likely generate higher levels of public trust and support in EU decisionmaking processes, thereby extending positive effects of applying such an approach beyond the field of social rights and onto the entire European integration.

Relying upon a criterion that does not pertain exclusively to one level of governance would also seem appropriate in view of the nature of EU citizenship that straddles both the national and the supranational sphere. This so-called fundamental status ${ }^{515}$ embeds within it dual belonging and identity of those who enjoy it. On the one hand, it stands for EU citizens' attachment to one (or more) of the constitutive national political communities. On the other hand, it represents EU citizens' connection to the larger, supranational polity of which these national communities form part.

This dual belonging arises from a simple conditionality that stands at the core of EU citizenship - one gets to enjoy this status primarily by virtue of holding

515 It was defined as such in the case C-184/99 Grzelczyk [2001] ECR I-6193, para 31, analyzed in more detail in Chapter I. 
a nationality of one (or more) of the EU Member States. ${ }^{516}$ The status of European citizenship and the rights that come with it can thus not be regarded as freestanding phenomena. Rather, this status should be seen as a symbol of ties that exist between the national and the supranational level, which are materialized in the very individuals who enjoy it. ${ }^{517}$ It would thus only be suitable to base future development of the concept of Union citizenship upon criteria grounded in values that are cherished and endorsed at both the national and the Union level, and are capable of surpassing dichotomies between them. ${ }^{518}$

This leads us to the final requirement that criteria for developing the social dimension of Union citizenship should satisfy. This requirement relates to the specific context in which the proposed alternative approach will be used - the area of social rights of EU citizens. When faced with different alternatives, actors responsible for defining this aspect of European integration should rely upon criteria that place those whose rights are at stake in the focus of normative concern. This means that when deciding about the future course of development of the social dimension of European citizenship, policy and lawmakers should work primarily towards securing social needs of citizens. While this may require a radical change in approach from the presently assumed ones, putting citizens in the focus of the analysis is crucial in order to sensibly address developments of this social aspect of European integration and render the citizenship of the Union a truly fundamental status.

I will argue that the principle of subsidiarity can satisfy these requirements, thereby providing an adequate way of constructing the project of European citizenship and supplying its social dimension with the needed legitimacy. Following a short description of its meaning and origins, I will examine what

\footnotetext{
516 As mentioned before, Article 20 of the TFEU provides that every person holding the nationality of a Member State shall be a citizen of the Union.

517 On the relationship that exists between the two statuses, namely State nationality and citizenship of the Union, see further Opinion of Advocate General Poiares Maduro in the case C-135/08 Rottmann [2010] ECR 00000. Also see Jo Shaw, 'Citizenship: Contrasting Dynamics at the Interface of Integration and Constitutionalism', EUI Working Paper RSCAS No. 2010/60.

${ }^{518}$ See further Mattias Kumm, 'The Legitimacy of International Law: A Constitutionalist Framework of Analysis' (2004) 15(5) EJIL 907, p. 931. Also see Jo Shaw, 'Citizenship: Contrasting Dynamics at the Interface of Integration and Constitutionalism', EUI Working Paper RSCAS No. 2010/60, p. 4.
} 
the application of subsidiarity entails in the field of social rights of EU citizens and why it represents a suitable alternative in this specific context.

It will be submitted that law and policy makers responsible for addressing the development of the social dimension of EU citizenship should pay due regard to the principle of subsidiarity in its entirety. This principle comprises not only the negative side which limits action at the higher level when lowers levels can achieve the envisaged goals, but also of the positive side which warrants action at the higher level when lower levels cannot sufficiently achieve the envisaged goals. It will be argued that taking both of these aspects of subsidiarity into consideration when addressing the development of the social dimension of EU citizenship can provide actors responsible for defining the contours of this field with the needed guidance.

Subsidiarity will be advanced as an adequate alternative not only because it can provide more transparency, coherency and legal certainty in the field of social rights of EU citizens, but also because, unlike the current approaches, it tends to put interests of those whose rights are at stake in the center of normative concern. In addition, it will be argued that subsidiarity represents a suitable choice in the current context of multi-level governance in the EU, which can both enable a dialogue and cooperation between the different levels, and function as a confidence-building mechanism. As such, subsidiarity can provide not only the needed guidance and a suitable standard of assessment for policy and lawmakers in this field, but also a means for supplying the social dimension of EU citizenship with the currently missing legitimacy.

\subsection{Subsidiarity as an alternative}

\subsubsection{The meaning and origins of the principle of subsidiarity}

Subsidiarity is a concept is deeply rooted in the history of the European political thought. ${ }^{519}$ While its first traces can be found in the philosophical

\footnotetext{
519 See Ken Endo, 'The Principle of Subsidiarity: From Johannes Althusius to Jacques Delors' Hokkaido L. Rev. (1994) 44(6), 652, p. 646; Paolo G. Carozza, 'Subsidiarity as a Structural Principle of International Human Rights Law', (2003) 97 American Journal of International Law 38, p. 40.
} 
teachings of Aristotle and Thomas Aquinas ${ }^{520}$, it is the Roman Catholic Church that systemized the principle of subsidiarity and made it truly important. ${ }^{521}$

One of the first formulations of subsidiarity, in this regard, can be found in the encyclical Rerum Novarum, dating back to $1891 . .^{522}$ This document, written by Pope Leo XIII, came as a product of an attempt to establish official Catholic teachings on the 'right social order' and the place of the Church and the State in it. ${ }^{523}$ Concerned mainly with the conditions of the working class and the poor in circumstances of unrestrained capitalism, Leo XIII declared: "Whenever the general interest or any particular class suffers, or is threatened with harm, which can in no other way be met or prevented, the public authority must step in to deal with it." ${ }^{524}$ He thereby developed a doctrine of subsidiarity that paved a way for public (State) intervention in the social field in favor of these categories of people. ${ }^{525}$

520 See Chantal Millon-Delsol, L'état subsidiaire: Ingérence et non-ingérence de l'Etat: le principe de subsidiarité aux fondements de l'histoire européenne (Presses Universitaires de France, Paris 1992); Chantal Millon-Delsol, Le Principe de Subsidiarité (Presses Universitaires de France, Paris 1993), pp. 9, 95; Didier Fouarge, Poverty and Subsidiarity in Europe: Minimum Protection from an Economic Perspective (Edward Elgar, Cheltenham 2004), p. 17; Ken Endo, Subsidiarity \& its Enemies: To What Extent Is Sovereignty Contested in the Mixed Commonwealth of Europe?, EUI Working Paper RSC No. 2001/24, p. 9; Paolo G. Carozza, 'Subsidiarity as a Structural Principle of International Human Rights Law', (2003) 97 American Journal of International Law 38, p. 41.

${ }^{521}$ Ken Endo, 'The Principle of Subsidiarity: From Johannes Althusius to Jacques Delors' Hokkaido L. Rev. (1994) 44(6), 652, p. 627.

522 See Paolo G. Carozza, 'Subsidiarity as a Structural Principle of International Human Rights Law', (2003) 97 American Journal of International Law 38, p. 41; Ken Endo, Subsidiarity \& its Enemies: To What Extent Is Sovereignty Contested in the Mixed Commonwealth of Europe?, EUI Working Paper RSC No. 2001/24, p. 16. ${ }^{523}$ See Didier Fouarge, Poverty and Subsidiarity in Europe: Minimum Protection from an Economic Perspective (Edward Elgar, Cheltenham 2004), p. 19; Ken Endo, Subsidiarity $\&$ its Enemies: To What Extent Is Sovereignty Contested in the Mixed Commonwealth of Europe?, EUI Working Paper RSC No. 2001/24, p. 17; Ken Endo, 'The Principle of Subsidiarity: From Johannes Althusius to Jacques Delors' Hokkaido L. Rev. (1994) 44(6), 652, p. 626.

${ }^{524}$ Leo XIII, Rerum Novarum, Encyclical on Capital and Labor, available at http://www.vatican.va/holy_father/leo_xiii/encyclicals/documents/hf_lxiii_enc_15051891_rerum-novarum_en.html, para 36.

525 See Paolo G. Carozza, 'Subsidiarity as a Structural Principle of International Human Rights Law’, (2003) 97 American Journal of International Law 38, p. 41; Ken 
His reasoning was driven by a belief that "each human individual is endowed with an inherent and inalienable worth, or dignity" ${ }^{226}$. The underlying conviction was that all forms of society, from the lowest to the highest ones, should ultimately be at the service of an individual, in order to enable flourishing and development of each person's potential. ${ }^{527}$ If a person can develop his/her own potential, society should not interfere in his/her business. ${ }^{528}$ If, on the contrary, $\mathrm{s} /$ he cannot attain his/her goals alone, various levels of society have an obligation to assist the person. ${ }^{529}$ Higher entities are thus not allowed to impede the sphere of individual freedom needed for personal self-realization, but they should assist lower entities in cases when human dignity is not secured. ${ }^{530}$ The foundation of the idea of subsidiarity is, in other words, the conviction of human dignity. ${ }^{531}$ This belief is in turn the source of the described duty of public intervention in the field of social affairs in favor "of the poor [who] have no resources of their own to fall back upon, and must chiefly depend upon the assistance of the State" 532 .

Yet, while Pope Leo XIII's starting point was the State's duty to protect workers from exploitation and guarantee the protection of their human dignity, he was cautious of the possibility of the over-expansion of State power. ${ }^{533} \mathrm{He}$, thus, sought to limit the possibility and the extent of public

Endo, 'The Principle of Subsidiarity: From Johannes Althusius to Jacques Delors' Hokkaido L. Rev. (1994) 44(6), 652, pp. 626-5.

526 Paolo G. Carozza, 'Subsidiarity as a Structural Principle of International Human Rights Law’, (2003) 97 American Journal of International Law 38, p. 42.

527 Ibid. Also see Ken Endo, 'The Principle of Subsidiarity: From Johannes Althusius to Jacques Delors' Hokkaido L. Rev. (1994) 44(6), 652, p. 617.

${ }^{528}$ Ken Endo, 'The Principle of Subsidiarity: From Johannes Althusius to Jacques

Delors' Hokkaido L. Rev. (1994) 44(6), 652, p. 615.

529 Ibid.

530 Ibid., p. 614; Didier Fouarge, Poverty and Subsidiarity in Europe: Minimum Protection from an Economic Perspective (Edward Elgar, Cheltenham 2004), p. 25.

531 See Chantal Millon-Delsol, Le Principe de Subsidiarité (Presses Universitaires de France, Paris 1993), pp. 27-8, 35; Didier Fouarge, Poverty and Subsidiarity in Europe: Minimum Protection from an Economic Perspective (Edward Elgar, Cheltenham 2004), p. 25; Ken Endo, 'The Principle of Subsidiarity: From Johannes Althusius to Jacques Delors' Hokkaido L. Rev. (1994) 44(6), 652, pp. 617-4; Paolo G. Carozza, 'Subsidiarity as a Structural Principle of International Human Rights Law', (2003) 97 American Journal of International Law 38, p. 42.

532 Leo XIII, Rerum Novarum, Encyclical on Capital and Labor, para 37.

533 See See Paolo G. Carozza, 'Subsidiarity as a Structural Principle of International Human Rights Law', (2003) 97 American Journal of International Law 38, p. 41; Ken 
intervention. To that end, he proclaimed: "The limits must be determined by the nature of the occasion which calls for the law's interference - the principle being that the law must not undertake more, nor proceed further, than is required for the remedy of the evil or the removal of the mischief." 534

The limits of public authority were later additionally emphasized by Leo XIII's successor Pope Pius XI in the encyclical Quadragesimo Anno, dating back to 1931. This document marked the fortieth anniversary of Rerum Novarum and further developed the doctrine of subsidiarity. In Quadragesimo Anno, Pius XI wrote: "As history abundantly proves, it is true that on account of changed conditions many things which were done by small associations in former times cannot be done now save by large associations. Still, that most weighty principle, which cannot be set aside or changed, remains fixed and unshaken in social philosophy: Just as it is gravely wrong to take from individuals what they can accomplish by their own initiative and industry and give it to the community, so also it is an injustice and at the same time a grave evil and disturbance of right order to assign to a greater and higher association what lesser and subordinate organizations can do. For every social activity ought of its very nature to furnish help to the members of the body social, and never destroy and absorb them.

The supreme authority of the State ought, therefore, to let subordinate groups handle matters and concerns of lesser importance, which would otherwise dissipate its efforts greatly. Thereby the State will more freely, powerfully, and effectively do all those things that belong to it alone because it alone can do them: directing, watching, urging, restraining, as occasion requires and necessity demands. Therefore, those in power should be sure that the more perfectly a graduated order is kept among the various associations, in observance of the principle of "subsidiary function," the stronger social authority and effectiveness will be the happier and more prosperous the condition of the State." ${ }^{535}$

Endo, 'The Principle of Subsidiarity: From Johannes Althusius to Jacques Delors' Hokkaido L. Rev. (1994) 44(6), 652, pp. 626-5; Ken Endo, Subsidiarity \& its Enemies: To What Extent Is Sovereignty Contested in the Mixed Commonwealth of Europe?, EUI Working Paper RSC No. 2001/24, p. 17.

${ }^{534}$ Leo XIII, Rerum Novarum, Encyclical on Capital and Labor, para 36.

535 Pius XI, Quadragesimo Anno: Encyclical on Reconstruction of the Social Order to our Venerable Brethren, the Patriarchs, Primates, Archbishops, Bishops, and Other Ordinaries in Peace and Communion with the Apostolic See, and Likewise to All the Faithful of the

Catholic World, available at 
This is considered to be the first explicit expression of the principle of subsidiarity ${ }^{536}$ and the starting point for all its subsequent uses ${ }^{537}$. Simply put, this formula suggests that entities of higher rank should intervene only in those matters that go beyond the reach of smaller entities. ${ }^{538}$ While Pius XI agreed that the State has duties in the field of social affairs and urged it to put into effect what was called for in Rerum Novarum, the emphasis was put on limits of public intervention. ${ }^{539}$ This was mainly a consequence of the historical moment in which Quadragesimo Anno was written, characterized by the rising threat of totalitarianism. ${ }^{540}$ Instead of emphasizing State duties, the Church thus sought to restrict public interference and express skepticism about excessive State control over society. ${ }^{541}$

Approximately half a century later, the principle of subsidiarity found its way into the primary law of the European Union. In 1991, it was included in the Treaty of Maastricht, thereby becoming one of the central constitutional principles of EU law. ${ }^{542}$ The operative definition adopted for that purpose stated: "In areas which do not fall within its exclusive competence, the Community shall take action, in accordance with the principle of subsidiarity,

http://www.vatican.va/holy_father/pius_xi/encyclicals/documents/hf_pxi_enc_19310515_quadragesimo-anno_en.html, paras 79, 80.

536 See Endo Ken, Subsidiarity \& its Enemies: To What Extent Is Sovereignty Contested in the Mixed Commonwealth of Europe?, EUI Working Paper RSC No. 2001/24, p. 18; Fouarge Didier, Poverty and Subsidiarity in Europe: Minimum Protection from an Economic Perspective (Edward Elgar, Cheltenham 2004), p. 19

537 Paolo G. Carozza, 'Subsidiarity as a Structural Principle of International Human Rights Law', (2003) 97 American Journal of International Law 38, p. 41.

538 Didier Fouarge, Poverty and Subsidiarity in Europe: Minimum Protection from an Economic Perspective (Edward Elgar, Cheltenham 2004), pp. 19-20.

539 See further Ken Endo, 'The Principle of Subsidiarity: From Johannes Althusius to Jacques Delors' Hokkaido L. Rev. (1994) 44(6), 652, pp. 623-2.

540 Ibid., p. 625. Also see Paolo G. Carozza, 'Subsidiarity as a Structural Principle of International Human Rights Law’, (2003) 97 American Journal of International Law 38 , p. 41.

541 Ibid.

542 See further Endo Ken, Subsidiarity \& its Enemies: To What Extent Is Sovereignty Contested in the Mixed Commonwealth of Europe?, EUI Working Paper RSC No. 2001/24, p. 6, 7, 24; Paolo G. Carozza, 'Subsidiarity as a Structural Principle of International Human Rights Law', (2003) 97 American Journal of International Law 38 , p. 38, 50. For a detailed description of the evolution of the principle of subsidiarity in the context of European integration see Ken Endo, 'The Principle of Subsidiarity: From Johannes Althusius to Jacques Delors' Hokkaido L. Rev. (1994) 44(6), 652. 
only if and in so far as the objectives of the proposed action cannot be sufficiently achieved by the Member States and can therefore, by reason of the scale or effects of the proposed action, be better achieved by the Community." 543

As clearly follows from this definition, in the European integration context, the principle of subsidiarity expresses preference for governance at the lower, Member States' level, unless the envisaged goals of the proposed action can be better achieved at the higher, Union level. Yet, this demand concerning the allocation of powers is not all there is to the principle of subsidiarity. The allocation of powers at the most appropriate level of governance comes merely as a consequence of the previously described inherent rationale underlying this principle. This has been acknowledged early in the process of introducing this principle in EU law by one of subsidiarity's strongest proponents, Jacques Delors. ${ }^{544}$ By emphasizing that the primary purpose of this principle is development and achievement of the full potential of each person ${ }^{545}$, Delors has pinpointed to what stands at the core of the principle of subsidiarity, namely, the idea of protection of human dignity. ${ }^{546}$

\footnotetext{
${ }^{543}$ Article $3 \mathrm{~b}$ of the Treaty on European Union (the Maastricht Treaty or TEU), Official Journal C 191 of 29 July 1992.

${ }^{544}$ See Ken Endo, 'The Principle of Subsidiarity: From Johannes Althusius to Jacques Delors' Hokkaido L. Rev. (1994) 44(6), 652, pp. 596-588. It is interesting to note in this regard that Delors has strongly advocated the application of the principle of subsidiarity precisely in the context of building the European social dimension. See
} Address given by Jacques Delors (Bruges, 17 October 1989), available at http://www.google.hr/url? sa=t\&rct=j\&q=\&esrc=s\&source=web\&cd=2\&ved=0CDM QFjAB\&url=http $\% 3 \mathrm{~A} \% 2 \mathrm{~F} \% 2 \mathrm{Fwww.cvce.eu} \% 2 \mathrm{Fcontent} \% 2 \mathrm{Fpublication} \% 2 \mathrm{~F} 2002 \%$ 2F12\%2F19\%2F5bbb1452-92c7-474b-a7cf-

a2d281898295\%2Fpublishable_en.pdf\&ei=sXe8ULb9Nc7itQamt4CgCQ\&usg=AF QjCNG9pPzso_tZ4Dra2Klqyoy1bdO2Dw\&sig2=ZBtvbcjX2cz9u8WfkYQ6ew\&ca $\mathrm{d}=$ rja. For a similar argument, also see Herman Hill, 'The Social Dimension and Subsidiarity' in Subsidiarity: The Challenge of Change (Proceedings of the Jacques Delors Colloquium) (European Institute of Public Admistration, 1991),

545 See Ken Endo, 'The Principle of Subsidiarity: From Johannes Althusius to Jacques Delors’ Hokkaido L. Rev. (1994) 44(6), 652, pp. 596-588.

${ }^{546}$ See Jacques Delors, 'Principle of Subsidiarity; Contribution to the Debate' in Subsidiarity: The Challenge of Change (Proceedings of the Jacques Delors Colloquium) (European Institute of Public Admistration, 1991), p. 9.As explained in more detail by Endo, "the idea of dignity is deeply connected with that of subsidiarity. On the one hand, an upper organisation should leave the sphere of freedom to each person. Only within this sphere' and through interactions with others can a person develop his/her 
In order to fulfill this function, subsidiarity plays an inherently bidirectional role - it may function as either a limit on, or a justification for, intervention on a higher level. 547

It can thus be concluded that the principle of subsidiarity necessarily consists of two aspects - the positive and the negative one ${ }^{548}$ - that represent two sides of the same coin. ${ }^{549}$ While the positive side of subsidiarity relates to the

full potentials. On the other hand, the society has to assist him/her when in trouble. In either of the cases, societies are necessary for the development of any person, therefore for the 'concretisation' of human dignity. This is why the principle of subsidiarity presupposes and defends various societies." Ken Endo, 'The Principle of Subsidiarity: From Johannes Althusius to Jacques Delors' Hokkaido L. Rev. (1994) 44(6), 652, p. 614. See also Chantal Millon-Delsol, Le Principe de Subsidiarité (Presses Universitaires de France, Paris 1993), pp. 27-8 and Chantal Millon-Delsol, L'état subsidiaire: Ingérence et non-ingérence de l'Etat: le principe de subsidiarité aux fondements de l'histoire européenne (Presses Universitaires de France, Paris 1992), pp. 123-126. ${ }^{547}$ Ibid. Also see Daniel Halberstam, 'Comparative Federalism and the Role of the Judiciary’, (Draft forthcoming) in Keith Whittington, Daniel Kelemen, and Gregory Caldeira (eds), The Oxford Handbook of Law and Politics (OUP, 2008), available at www.law.ed.ac.uk/europa/files/halberstamcomparativefederalismjudiciary.pdf, p. 9. In this regard, Delors clarifies that subsidiarity as a principle comprises of two infrangible aspects: "the right of each to exercise his responsibilities there where he can perform them best, and the obligation of the public authorities to give to each the means to reach his full capacity.” Jacques Delors, 'Principle of Subsidiarity; Contribution to the Debate' in Subsidiarity: The Challenge of Change (Proceedings of the Jacques Delors Colloquium) (European Institute of Public Admistration, 1991), p. 18. 548 Strong normative connotations attached to the terms 'positive' and 'negative' subsidiarity raise some doubts as to the appropriateness of this terminology. Since it seemingly expresses a bias towards negative and in favor of positive subsidiairity, this terminology does not seem to constitute the most sensible choice. Yet, given its wellestablished character and its continued usage in the academic literature (see footnote 549 below), I will continue rely upon this terminology in describing different meanings of the principle of subsidiarity.

${ }^{549}$ As explained by Millon- Delsol: "L'idée de subsidiarité, véritable pilier de la " doctrine sociale ", s'entend à la fois dans son sens négatif - non-ingérence, parce que la dignité contient la liberté -, et dans son sens positif- ingérence si nécessaire, parce que la liberté ne suffit pas toujours à garantir la dignité.” Chantal Millon-Delsol, Le Principe de Subsidiarité (Presses Universitaires de France, Paris 1993), pp. 27-8. On these two meanings of subsidiarity, also see Ken Endo, 'The Principle of Subsidiarity: From Johannes Althusius to Jacques Delors' Hokkaido L. Rev. (1994) 44(6), 652, p. 642; Didier Fouarge, Poverty and Subsidiarity in Europe: Minimum Protection from an Economic Perspective (Edward Elgar, Cheltenham 2004), p. 30; Paolo G. Carozza, 
possibility of intervention of a higher entity vis-à-vis a lower entity, its negative side refers to the limits of such intervention. ${ }^{550}$ More precisely, positive subsidiarity warrants the intervention by a higher organization in the affairs of lower entities when they cannot alone accomplish their goals. ${ }^{551}$ Negative subsidiarity limits the intervention of a higher authority in cases where lower entities can on their own accomplish their aims. ${ }^{552}$

The positive and the negative side of subsidiarity are necessarily tied together since they arise from the same premises. ${ }^{553}$ They should thus be regarded as implicit to one another despite the occasional emphasis on one of them in different formulations of the principle of subsidiarity. ${ }^{554}$ Since subsidiarity simultaneously calls for intervention and non-interference by higher

'Subsidiarity as a Structural Principle of International Human Rights Law’, (2003) 97 American Journal of International Law 38, p. 44; Andreas Follesdal, 'Subsidiarity' (1998) 6(2) Journal of Political Philosophy 231.

550 Ken Endo, 'The Principle of Subsidiarity: From Johannes Althusius to Jacques Delors' Hokkaido L. Rev. (1994) 44(6), 652, p. 642. As Endo explains, the word 'higher' refers to 'superior' or 'bigger', while the word 'lower' refers to 'inferior' or 'smaller'.

551 Ibid., pp. 641, 566.

552 Ibid., pp. 642-1. Or, as elaborately explained by Millon-Delsol: "Le principe de subsidiarité présente un double aspect, répercutant cette double exigence : - un aspect négatif : l'autorité en général et l'Etat en particulier ne doivent pas empêcher les personnes ou groupes sociaux de conduire leurs actions propres, c'est-à-dire de déployer autant que possible leur énergie, leur imagination, leur persévérance, dans les oeuvres par lesquelles ils se réalisent tant au profit de l'intérêt général que de l'intérêt particulier; - un aspect positif : chaque autorité a pour mission d'inciter, de soutenir, et en dernier lieu, de suppléer s'il le faut, les acteurs insuffisants.”. Chantal Millon-Delsol, Le Principe de Subsidiarité (Presses Universitaires de France, Paris 1993), p. 7.

553 See Ibid., p. 567-6; Paolo G. Carozza, 'Subsidiarity as a Structural Principle of International Human Rights Law', (2003) 97 American Journal of International Law 38, p. 44; Didier Fouarge, Poverty and Subsidiarity in Europe: Minimum Protection from an Economic Perspective (Edward Elgar, Cheltenham 2004), p. 30.

${ }^{554}$ For example, in Rerum Novarum, Leo XIII put a stronger emphasis on the positive aspect of the principle of subsidiarity, while in Quadragesimo Anno, Pius XI emphasized its negative meaning. The negative meaning of subsidiarity was also often emphasized in the context of European integration. See further Ken Endo, 'The Principle of Subsidiarity: From Johannes Althusius to Jacques Delors' Hokkaido L. Rev. (1994) 44(6), 652. 
authorities, it is often characterized as a somewhat paradoxical principle. ${ }^{555}$ Yet, it is precisely this inherent paradox that is considered to be the key to understanding the meaning of the principle of subsidiarity. 556

Unfortunately, the rationale underlying this principle and the two dimensions of subsidiarity that follow from it seemed to have been somewhat forgotten in the course of development of European integration. Instead, the focus has switched mainly on the allocation of powers as a direct demand of this principle and on the negative meaning of subsidiarity in the EU. 557 This has lead some to conclude that subsidiarity in the EU has little to do with the principled affirmation of human dignity ${ }^{558}$, and that it was rather envisaged as "a response to the profound transformation in the balance of power between the Community and the member states in the period before conclusion of the Maastricht Treaty". 559

While the requirement to allocate powers at the most appropriate level of governance forms an important part of the principle of subsidiarity, it is merely a consequence of its underlying rationale, which puts individuals and their right to dignity in the focus of the analysis. Policy and lawmakers in the EU should not ignore this basic idea standing behind the principle of subsidiarity and the inherently bidirectional role that derives from it. On the contrary, if they are to secure full compliance with this central constitutional principle of EU law, national and European actors should acknowledge this basic rationale and inherent mechanics of the principle of subsidiarity, and

\footnotetext{
555 See Chantal Millon-Delsol, L'état subsidiaire: Ingérence et non-ingérence de l'Etat: le principe de subsidiarité aux fondements de l'histoire européenne (Presses Universitaires de France, Paris 1992), p. 8; Paolo G. Carozza, 'Subsidiarity as a Structural Principle of International Human Rights Law', (2003) 97 American Journal of International Law 38 , p. 44.

556 Ibid.; Ken Endo, 'The Principle of Subsidiarity: From Johannes Althusius to Jacques Delors' Hokkaido L. Rev. (1994) 44(6), 652, p. 640.

${ }^{557}$ See further Ken Endo, 'The Principle of Subsidiarity: From Johannes Althusius to Jacques Delors’ Hokkaido L. Rev. (1994) 44(6), 652, Chapter III.

558 Paolo G. Carozza, 'Subsidiarity as a Structural Principle of International Human Rights Law’, (2003) 97 American Journal of International Law 38, p. 51.

${ }^{559}$ Ibid. See further Ken Endo, 'The Principle of Subsidiarity: From Johannes Althusius to Jacques Delors' Hokkaido L. Rev. (1994) 44(6), 652 and Paul P. Craig, 'Subsidiarity, a Political and Legal Analysis' (2012) 50 Journal of Common Market Studies 72, available at http://papers.ssrn.com/sol3/papers.cfm?abstract_id=2028332.
} 
shape their decisions accordingly.

\subsubsection{Applying subsidiarity in the context of social rights of EU citizens}

In EU law, the principle of subsidiarity is today defined in Article 5(3) of the Lisbon Treaty. According to this Article, "in areas which do not fall within its exclusive competence, the Union shall act only if and in so far as the objectives of the proposed action cannot be sufficiently achieved by the Member States, either at central level or at regional and local level, but can rather, by reason of the scale or effects of the proposed action, be better achieved at Union level." 560

Two propositions follow from this definition. First, in the field of shared competences, the principle of subsidiarity limits the Union action in cases where the Member States can on their own sufficiently attain the envisaged goals. This is the negative aspect of subsidiarity in the context of European integration. Second, the principle of subsidiarity warrants the Union action in the areas of non-exclusive competences when the Member States alone cannot sufficiently achieve the envisaged objectives. This is the positive aspect of subsidiarity in the EU.

In the context of European integration, the emphasis has been often put on negative subsidiarity ${ }^{561}$, while its positive side has been somewhat neglected. This is regrettable not only because the two aspects of subsidiarity should not be decoupled if one is to ensure full compliance with this principle, but also because positive subsidiarity can provide a particularly useful guidance for policy and lawmakers concerned with the future of European integration. More concretely, in the context of social rights of EU citizens, it can provide them with a needed sense of direction and a useful tool for supplying this field with the currently missing legitimacy.

Given its focus on action, rather then abstention, positive subsidiarity draws the attention of responsible actors towards their problem-solving potential and provides them with an incentive to think about the best ways to address the future of the European social dimension. It thus constitutes not only an

\footnotetext{
560 Article 5(3) of the TEU.

561 See further Ken Endo, 'The Principle of Subsidiarity: From Johannes Althusius to Jacques Delors’ Hokkaido L. Rev. (1994) 44(6), 652, Chapter III.
} 
inherent part of the principle of subsidiarity, but also an important addition to its negative aspect that can provide valuable guidance in constructing the social dimension of EU citizenship. For those reasons, in addition to negative subsidiarity, decision-makers responsible for defining social rights of EU citizens should acknowledge and pay due respect to normative demands of positive subsidiarity in framing their decisions.

Before turning to other perceived advantages of taking both negative and positive subsidiarity into serious consideration when defining the social aspect of EU citizenship, I would like to describe in a little more detail what the application of subsidiarity principle would entail in this specific context. As explained above, negative subsidiarity limits the Union action in a field of shared competence when the Member States can on their own sufficiently attain the envisaged goals. Positive subsidiarity warrants the EU intervention in a field of shared competence when the Member States are not capable of achieving the envisaged aims on their own, and when these aims can be better achieved at the Union level. Defining the scope and the content of social rights of EU citizens pertains mainly to the area of social policy. According to Article 4 of the Lisbon Treaty, this is one of the areas where the Union shares competence with the Member States. ${ }^{562}$ It follows that, in regulating access to social rights of EU citizens and, more generally, in defining the contours of the social dimension of EU citizenship, the negative and the positive aspect of subsidiarity can be used as guiding criteria. ${ }^{563}$

However, in order to determine more precise demands of subsidiarity principle as a whole in the context of migrant EU citizens' social rights, one needs to identify relevant aims envisaged in this field. In the Lisbon Treaty, we find several important objectives pertaining to this area. Article 3(1) of the TEU proclaims that the Union's aim is to promote "the well-being of its peoples". To that end, Article 3(3) of the TEU prescribes that "the Union shall combat social exclusion" and "promote social justice and protection". Article 151 of the TFEU further declares that the Union and the Member States shall have as their objectives the promotion of, amongst others, improved living and working conditions, proper social protection and the combating of social

\footnotetext{
562 Article 4 of the TFEU.

563 A similar suggestion regarding the application of positive subsidiarity was made by Fouarge in the more general context of protection of human rights and poverty prevention in the EU. See Didier Fouarge, Poverty and Subsidiarity in Europe: Minimum Protection from an Economic Perspective (Edward Elgar, Cheltenham 2004). p. 30.
} 
exclusion. The Charter of Fundamental Rights of the European Union is also relevant in this regard. It restates the goal of combating social exclusion and poverty, and declares recognition and respect of "the right to social and housing assistance so as to ensure a decent existence for all those who lack sufficient resources". 564

Having identified the relevant objectives in the field of social policy, it can be more closely determined what the application of subsidiarity implies in the context of social rights of Union citizens. According to the previously described formula, negative subsidiarity limits the Union action in the field of social rights of EU citizens when the Member States can on their own sufficiently attain the envisaged goals of combating social exclusion, promoting social justice and protection, and ensuring a decent existence of citizens who lack sufficient resources. Positive subsidiary warrants the EU regulation in the social field of EU citizenship, when the Member States cannot on their own combat social exclusion, promote social justice and protection, and ensure a decent existence of citizens who lack sufficient resources. In other words, when the Member States succeed in ensuring a decent existence of migrant EU citizens living in their territory, negative subsidiarity will require the EU to abstain from any intervention in this field. On the other hand, when the Member States fail to provide social guarantees needed to ensure a decent existence of migrant EU citizens living in their territory, positive subsidiarity will call for the EU intervention in this area.

The principle of subsidiarity, however, requires that each and every action proposed and adopted at the EU level needs to be justified. This has to be done by showing that the Member States, left to their own devices, could not do an adequate job of furthering the envisaged goals. ${ }^{565}$ In addition, the provided justification has to prove that the attainment of the relevant objectives can be better secured at the Union level. Particular regard should be paid to the requirements listed in Article 5 of the Protocol on the application of the principles of subsidiarity and proportionality.

This Article prescribes that "Draft legislative acts shall be justified with regard

\footnotetext{
564 Article 34 of the Charter of Fundamental Rights of the European Union, Official Journal C 303/1 of 14 December 2007 ('the Charter').

565 See George A. Bermann, 'Taking Subsidiarity Seriously: Federalism in the

European Community and the United States', (1994) 94 Colum. L. Rev. 331, pp. 3845 .
} 
to the principles of subsidiarity and proportionality. Any draft legislative act should contain a detailed statement making it possible to appraise compliance with the principles of subsidiarity and proportionality. This statement should contain some assessment of the proposal's financial impact and, in the case of a directive, of its implications for the rules to be put in place by Member States, including, where necessary, the regional legislation. The reasons for concluding that a Union objective can be better achieved at Union level shall be substantiated by qualitative and, wherever possible, quantitative indicators. Draft legislative acts shall take account of the need for any burden, whether financial or administrative, falling upon the Union, national governments, regional or local authorities, economic operators and citizens, to be minimised and commensurate with the objective to be achieved." 566

While the Protocol puts an emphasis on the role of legislative bodies, it should be noted that other institutions also have an important role to play in securing the observance of the principle of subsidiarity in the social rights field of EU citizenship. Asides from the legislative bodies, this also includes the judiciary and all other actors responsible for defining the social dimension of Union citizenship. This follows from the requirement of Article 1 of the Protocol, providing that each institution should ensure constant respect for the principle of subsidiarity.

Accordingly, both legislative and judicial bodies, each in their own respective roles, should act as the guardians of subsidiarity and its proper application in the field of social rights of EU citizens. Asides from the European Commission, the Council and the European Parliament, this also includes the Court of Justice of the European Union. ${ }^{567}$ The Court, who has so far been the leading force in expanding the concept of EU citizenship, should regard the principle of subsidiarity, including both its negative and positive aspect,

\footnotetext{
566 Article 5, the Protocol (No 2) on the application of the principles of subsidiarity and proportionality, Official Journal C 115/206 of 9 May 2008 ('the Protocol').

567 As Estella notes, the list does not end here. Article 1 of the Protocol implies that all EU institutions with a decisional capacity need to observe the principle of subsidiarity when they act. See Antonio Estella, The EU Principle of Subsidiarity and its Critique (OUP, 2002), pp. 101-2. For a more detailed description of the specific roles assigned to these institutions, see Protocol (No 2) on the application of the principles of subsidiarity and proportionality, Official Journal C 115/206 of 9 May 2008.
} 
when interpreting EU legislation ${ }^{568}$ and reviewing it for legality ${ }^{569}$.

At the national level, asides from the national parliaments for whom the Protocol reserves a special role ${ }^{570}$, other actors also have a role to play in securing respect of subsidiarity. Under Article 267 of the TFEU, national courts can refer questions to the Court of Justice concerning compliance of EU legislation with this basic constitutional principle. Pursuant to Article 263 of the TFEU, the Member States' governments can also partake by bringing actions before the Court of Justice and asking it to review compliance of EU measures with the principle of subsidiarity. Finally, when administering and enforcing EU legislation, various Member State officials should, in case of doubt, favor the interpretation that most respects this principle. ${ }^{571}$

Functions of subsidiarity are thus manifold. ${ }^{572}$ Asides from the legislative function, subsidiarity also has an adjudicatory and an interpretative role to play, thereby providing guidance and a standard of assessment designed for multiple actors at both levels of governance.

In the specific context of social rights of EU citizens and having in mind both the negative and the positive aspect of the principle of subsidiarity, this implies the following: In its legislative role, subsidiarity requires participants of the legislative process to determine whether the Member States can on their own attain the goals envisaged in this field. If the Member States can attain the envisaged objectives, negative subsidiarity will require abstention from intervention at the EU level. If the Member States cannot on their own attain the envisaged goals, positive subsidiarity will warrant legislative intervention in this field at the EU level, along with the justification of any proposed measures. In the adjudicatory role, subsidiarity requires the EU judiciary to review validity of actions taken at the Union level under this

\footnotetext{
568 On the interpretative function of the principle of subsidiarity see George A. Bermann, 'Taking Subsidiarity Seriously: Federalism in the European Community and the United States', (1994) 94 Colum. L. Rev. 331, pp. 366-7.

569 On the adjudicatory function of the principle of subsidiarity see ibid., pp. 367-8. On the interpretative and adjudicatory function of the principle of subsidiarity, also see Gráinne de Búrca, 'The Principle of Subsidiarity and the Court of Justice as an Institutional Actor', (1998) 36(2) Journal of Common Market Studies 217.

570 See, in particular, Article 4, 6 and 7 of the Protocol.

${ }^{571}$ George A. Bermann, 'Taking Subsidiarity Seriously: Federalism in the European Community and the United States', (1994) 94 Colum. L. Rev. 331, pp. 366-7.

$572 \mathrm{On}$ different functions of subsidiarity, see further bid.
} 
principle, when such review is requested. Finally, in its interpretative role, it calls all bodies responsible for interpreting EU legislation to favor the interpretation that best adheres to demands of subsidiarity. This includes not only the Union judiciary, most notably the Court of Justice, but also the national judiciary and various other national officials responsible for administering and enforcing EU legislation. ${ }^{573}$

\subsubsection{Why subsidiarity?}

The question that remains to be answered is what makes subsidiarity an adequate criterion for developing the social dimension of EU citizenship. What are the advantages of applying this principle in comparison to the currently assumed approaches? Could taking into account of its positive aspect, while simultaneously respecting demands of its negative one, really constitute a suitable method for defining the social aspect of EU citizenship? Finally, can reliance upon this principle provide the needed tool for coherent construction of the legitimacy of social rights of EU citizens?

The argument presented here will be that subsidiarity can not only serve as helpful guidance and a suitable standard of assessment for policy and lawmakers in this field, but also as means of providing the social aspect of EU citizenship with the currently missing legitimacy. There are several reasons for taking subsidiarity into serious consideration when shaping the future of the European social dimension.

First, subsidiarity provides for a standard of assessment capable of generating more coherence in decision-making than the approaches currently assumed in this field. As previously explained, the approaches employed at the Union level tend to put opposing interests and goals in the social policy field on equal footing, leaving responsible actors to randomly strike a balance between them. ${ }^{574}$ Since they express no preference for either of the conflicting aims, they provide hardly any guidance at all.

Subsidiarity is, on the contrary, geared towards the achievement of mutually compatible objectives envisaged in the social policy field - the goal of fighting

\footnotetext{
573 Ibid., pp. 366-7.

574 As explained in Chapter I, the goals standing in opposition to one another in the field of social rights of EU citizens are, on the one hand, the goal of promoting the freedom of movement in the EU and social solidarity as its corollary, and, on the other, the goal of protecting Member States' finances and social security systems.
} 
social exclusion, promoting social protection and well-being of EU citizens, and consequently providing them with social guarantees needed to ensure their decent existence. The application of subsidiarity in the area of social rights of EU citizens is thus aimed primarily at the achievement of these aims, placing all other (possibly contradictory) interests or goals in the secondary place. As such, it provides for a better sense of direction to those responsible for defining the social dimension of EU citizenship and is, in turn, capable of generating more coherent results that the ones witnessed so far.

Asides from providing more informative guidance substantively speaking, subsidiarity also provides guidance as to the appropriate level of governance on which action should be taken. It favors the national level, unless the Member States alone cannot sufficiently accomplish the envisaged aims. In this way, asides from substantive guidance, subsidiarity also provides procedural guidance for policy and lawmakers. As a result, and in comparison to the currently assumed approaches in this field, this principle comprises a considerably more informative standard and, thus, a more helpful way of defining the social aspect of Union citizenship.

Another reason in favor of subsidiarity is its ability to generate more transparency and ultimately legal certainty in decision-making. This derives from the previously described requirement to provide a detailed justification, preferably empirically grounded, for any action taken at the Union level. The possibility of control of compliance with the principle of subsidiarity by legislative and judicial actors at both levels of governance would also seem to play a role in this regard. Different available types of external control would necessarily put pressure on policy and lawmakers to reach more transparent, consistent and better-reasoned decisions, in order to minimize the chances of their rejection or invalidation. All of this, in turn, would reduce the possibility of reaching ambiguous decisions and manipulating results of the analysis, thereby rendering subsidiarity a more adequate criterion than the sovereignty-related approach, assumed at the national level. ${ }^{575}$

\footnotetext{
575 It is worth noting in this regard that different authors have previously qualified subsidiarity as a useful conceptual alternative for replacing the unhelpful concept of sovereignty. See, for example, Mattias Kumm, 'The Legitimacy of International Law: A Constitutionalist Framework of Analysis' (2004) 15(5) EJIL 907, pp. 920-1; Paolo G. Carozza, 'Subsidiarity as a Structural Principle of International Human Rights Law', (2003) 97 American Journal of International Law 38, p. 40. On the strengths of subsidiarity vis-à-vis sovereignty, also see Ken Endo, Subsidiarity \& its Enemies: To
} 
By requiring national and EU actors to engage in a mutual control on the basis of uniform inquiry focused on achieving common goals ${ }^{576}$, subsidiarity serves another noteworthy purpose. It creates a level playing field and a platform for a constructive dialogue and cooperation of all actors responsible for defining the social dimension of European citizenship. As such, it provides not only a tool for a better-informed decision-making, but also a "conceptual framework that transcends old dichotomies" 577 between the national and the supranational level. Subsidiarity thus constitutes an appropriate tool for multilevel governance 578 - suitable for employment by actors at both the national and the supranational level, and geared towards securing the best results for citizens.

This leads us to the fourth reason in favor of reliance on subsidiarity in addressing the future development of EU citizens' social rights. This principle places interests of those whose rights are at stake, rather then those of state or EU institutions, in the center of normative concern. As such, it compels responsible national and EU actors to work together towards securing basic social needs of citizens. By switching their focus on the best ways to achieve this mutually envisaged goal, subsidiarity puts actors at both levels of governance in direct service of citizens. This makes it an appropriate way of defining the contours of EU citizenship - the concept that straddles both the national and the supranational sphere. Ultimately, because it focuses on

What Extent Is Sovereignty Contested in the Mixed Commonwealth of Europe?, EUI Working Paper RSC No. 2001/24.

576 The wording of the Treaty, particularly Article 151 of the TFEU, is quite indicative in this regard, as it provides that the Union and the Member States shall have as their objectives the promotion of, amongst others, improved living and working conditions, proper social protection and the combating of exclusion.

577 This terminology is borrowed from Mattias Kumm, 'The Legitimacy of International Law: A Constitutionalist Framework of Analysis' (2004) 15(5) EJIL 907, p. 931. Dichotomies between the national and the supranational level are very much kept alive by the approaches currently employed in the field of social rights of EU citizens. Unlike these approaches, positive subsidiarity does not seek to prioritize either states' or the Union interests. Rather it focuses on their common goals and compels actors at both levels of governance to work together on the best ways to accomplish them.

578 Other authors have also remarked that subsidiarity implies a shift away from hierarchical governance and represents a principle constitutive of multilevel governance. See, for example Ken Endo, Subsidiarity \& its Enemies: To What Extent Is Sovereignty Contested in the Mixed Commonwealth of Europe?, EUI Working Paper RSC No. 2001/24; Gráinne de Búrca and Paul Craig, EU Law: Text, Cases and Materials (5 $5^{\text {th }}$ edn OUP, Oxford 2011), p. 169 
ensuring the best results for citizens and securing their social needs, subsidiarity constitutes a sensible way of constructing the social dimension of EU citizenship.

José Manuel Barroso, the current president of the European Commission, seemed to have expressed a similar idea in his guidelines for the Commission, by stating: "We must kill off the idea that the Member States and the EU level are rivals. Everyone should be working to the same goal - to secure the best results for citizens. Too often, mistrust has been the cause of failings in our system [...]. The question is how best to improve this. That means an effective application of the principle of subsidiarity. For me, subsidiarity is the translation of a democratic principle, part of a very practical doctrine, aimed at making public policy work to best effect in a Union built on solidarity, and at the most appropriate level." 579

Understood in this way, subsidiarity has an additional role to play in the field of social rights of EU citizens. It can perform a confidence-building function by providing reassurance that decisions taken will focus on securing the best results for citizens while respecting distinctiveness of different levels of governance. ${ }^{580}$ By providing a guarantee that available Member States' alternatives are genuinely taken into consideration when deciding how to best advance interests of citizens, the decisional process grounded in subsidiarity would likely win greater trust and support among the European public in large. ${ }^{581}$ This would, in turn, enhance the legitimacy of the adopted measures and, more generally, the social dimension of EU citizenship. ${ }^{582}$

For all its qualities, resistance to endorse subsidiarity as a guiding criterion in the social rights field might still come from those who believe that the expansion of social solidarity is not possible beyond national political communities, because people from different Member States do not share a common sense of identity needed to back redistributive social schemes and

\footnotetext{
${ }^{579}$ José Manuel Barroso, Political Guidelines for the next Commission, European Commission, September 2009, available at ec.europa.eu/commission_20102014/president/pdf/press_20090903_en.pdf

580 See George A. Bermann, 'Taking Subsidiarity Seriously: Federalism in the European Community and the United States', (1994) 94 Colum. L. Rev. 331, p. 367. 581 Ibid., p. 391.

582 See ibid., p. 367.
} 
the corresponding provision of social guarantees. ${ }^{583}$ Indeed, abiding by demands of subsidiarity requires a radical change in approach of those who consider nation-state boundaries to be the boundaries of social solidarity. That is to say, faithful application of this principle implies stepping away from this kind of ideology as it envisages the possibility of regulating social rights and extending solidarity at the supranational level. Yet, there are good reasons for such a change in approach.

The expansion of solidarity and social rights beyond national borders has already taken place in the EU. An example of that is the analyzed case law and legislation regulating access to social benefits of non-economic migrant Union citizens in Member States of which they are not nationals. Despite the lack of common national identity that binds them, European citizens did not seem to object to such a provision of stronger social guarantees at the Union level. On the contrary, they keep expressing their desire to witness even greater expansion of social rights and solidarity in the EU. ${ }^{584}$

This should come as no surprise. Self-determinative choices of EU citizens in the social rights' field are sometimes best advanced at the supranational level. This is due to the ability of the Union to lift "individual[s] from the exclusive confines of Member State processes of political decision making”, by allowing the shift of focus from policy preferences of state governments to "European citizens as the immediate subjects of normative concern". ${ }^{585}$ This is also due to the wider territorial and regulatory reach of decisions taken at the EU level. Because of States' inability to regulate across borders or

\footnotetext{
583 As Habermas explains, this belief is usually grounded in "the premise that the willingness of citizens to expose themselves to the risks of a redistributive social state cannot be fully explained without this ascriptive form of solidarity, the sense of being "one of us." On this reading, only a sense of national belonging understood as membership in a pre-political community of fate can exert the kind of binding effect, and can produce the sort of solidarity, that explain why self-interested citizens would place the demands of a "duty-imposing" state authority ahead of their own preferences." Jürgen Habermas, 'The Postnational Constellation and the Future of Democracy' in The Postnational Constellation: Political Essays, ed. and trans. Max Pensky (The MIT Press, Cambridge 2001), pp. 100-1.

${ }^{584}$ See footnote 8 above.

585 Daniel Halberstam, 'The Bride of Messina: Constitutionalism and Democracy in Europe' (2005) 30 EL Rev 755, pp. 785, 788. Also see Julio Baquero Cruz, 'The Legacy of the Maastricht-Urteil and the Pluralist Movement', EUI Working Paper RSCAS No. 2007/13, pp. 17-8.
} 
effectively respond to global challenges, decisions taken at the national level will often simply not have the capacity to satisfy the needs and desires of its citizens in the field of social policy. 586

Thus, in circumstances where an increase of social guarantees at the EU level corresponds to EU citizens' shared needs and interests, and where the Union is able and determined to serve them, the expansion of solidarity beyond national borders is not only possible, but also desirable. ${ }^{587}$ Consequently, the application and resulting implications of subsidiarity in the social rights field of EU citizenship should not be a cause for concern. What should be a cause for concern are ideologies that a priori renounce the possibility of expansion of social rights and solidarity beyond national borders, as they are not only myopic, but also potentially detrimental to the realization of citizens' interests.

\subsection{Conclusion}

The aim of this chapter was to engage in a search for a criterion suitable for guiding the future development of social rights of EU citizens. This was done in view of the current context of European integration, marked by a lack of a comprehensive social agenda and the employment of inadequate standards for defining the social dimension of EU citizenship. As a result of this search, it was suggested that the principle of subsidiarity could provide adequate guidance for policy and lawmakers in this field.

\footnotetext{
586 See further Jürgen Habermas, 'The Postnational Constellation and the Future of Democracy' in The Postnational Constellation: Political Essays, ed. and trans. Max Pensky (The MIT Press, Cambridge 2001). Also see Jürgen Habermas, The Crisis of the European Union: A Response (Polity Press, Cambridge 2012), pp. x-xi, 53, 55.

587 As explained by Krehoff in his elaboration of Joseph Raz's conception of legitimate political authority, "The central question when it comes to determine the legitimacy of authority should be one of values. What values do we want to pursue, and who should be in charge of serving them? [...] Such a problem-oriented approach opens the way for innovative answers beyond the traditional state-centered thinking." Razian account of authority is thus "not tailored to the form of states, but to the reasons for action which are relevant in the political domain. According to this account, political authority is justified if it can help its subjects to improve conformity with those reasons. Depending on the circumstances, states may be the appropriate candidates for this job. But there is no prejudication, no default assumption in favour of states." Bernd Krehoff, 'Legitimate Political Authority and Sovereignty: Why States Cannot be the Whole Story' (2008) 14 Res Publica 283, pp. 284, 296.
} 
This principle, to which EU law assigns a central constitutional role, consists of two aspects - the positive and the negative one. In the context of European integration, the negative aspect of subsidiarity has been emphasized, while the positive one has been rather neglected. The argument presented here is that policy and lawmakers should acknowledge the importance of both negative and positive subsidiarity and put equal weight on their demands in decision-making. They should do so not only because the two sides go hand in hand and form inherent parts of this general principle of EU law, but also because taking both of them into consideration can provide the needed guidance in the field of social rights of EU citizens.

Specific reasons in favor of applying the principle of subsidiarity in this context are many. Asides from its ability to lead to more coherent results then the currently assumed approaches, this principle is also less susceptible to manipulation and arbitrary and intransparent decision-making. This in turn makes it more prone to generating legal certainty in this field. In addition, subsidiarity comprises an adequate tool for multilevel governance, which can enable a constructive dialogue and cooperation between the national and the supranational level. It also seems to constitute a sensible choice from the point of view of those whose rights are at stake, namely EU citizens, since it puts their interests in the center of normative concern. For all those reasons, decisionmaking processes based on this principle would likely win greater trust and supply the social dimension of EU citizenship with the needed legitimacy.

All this is not to say that the application of subsidiarity will automatically resolve problems created by inherent tensions in the field of social policy. ${ }^{588}$ In other words, the application of this principle cannot simply eliminate the need to balance between opposing interests and goals in certain cases. It can, however, provide a framework within which balancing can take place, consequently, making the results of this process less arbitrary and incoherent than they presently are. It can do this by providing those who shape the contours of the social dimension of EU citizenship with a sense of direction and a constant reminder that they should work towards the achievement of the common objectives envisaged in the field of social policy. While this may not imply straightforward answers to hard questions, it can provide the needed inspiration and guidance for policy and lawmakers in this field, and help them turn the citizenship of the Union into a truly fundamental status of the Member States' nationals.

588 See the Introductory Chapter for a more detailed account of these tensions. 


\section{Conclusions}

Calling EU citizenship a fundamental status of the Member States' nationals ${ }^{589}$ does not make it so. A title like this needs to be well deserved and justified. As far as its social dimension is concerned, there seems to be little proof that Union citizenship has so far played a fundamental role for those who enjoy it. This is not to say that it could not. The concept of EU citizenship is undoubtedly the one of great potential. Its content, however, and the overall placing within the project of European integration are yet to be fully explored and defined.

Defining the contours of EU citizenship and particularly its social dimension is not an easy task. It implies making far-reaching choices on the nature of the entire European integration. In particular, it implies deciding whether and to which extent should the European project go beyond market integration and towards a political one in which a degree of social solidarity is required as a consequence of membership in such a community. ${ }^{590}$

Deciding whether there should be such thing as 'Social Europe' and, if so, what should it consist of is a highly controversial matter. The controversy surrounding it arises from tensions between opposing interests and goals present in the field of social policy. As a result of a historical development of national welfare systems and its ties to the process of nation-state building ${ }^{591}$, national policy and lawmakers still regard the area of social policy as the one

589 See Case C-184/99 Grzelczyk [2001] ECR I-6193, para 31.

590 See Miguel Poiares Maduro, 'Striking the Elusive Balance Between Economic Freedom and Social Rights in the EU' in Philip Alston (ed), The EU and Human Rights (OUP, Oxford 2000), p. 466.

591 See further Kay Hailbronner, 'Union Citizenship and Access to Social Benefits' (2005) 42 CML Rev. 1245, p. 1265. Also see John Loughlin, 'The 'Hybrid' State: Reconfiguring Territorial Governance in Western' Europe' (2009) 10 Perspectives on European Politics and Society 51. 
that engages a compelling state interest. From their point of view, the prospect of regulation of social issues at the EU level is viewed as risky business that could lead to a demise of nation-states. In legal terms, this reasoning finds its expression in the highest national tribunals' identification of the social policy field as a vital, necessary and untransferable state competence. 592

The budgetary aspects related to the provision of welfare benefits additionally strengthen this attitude. In the current context of European integration, Member States still constitute the primary providers of social benefits. Since the financial burden of guaranteeing social rights remains principally with the Member State and since financing welfare systems can have serious consequences on state budgets, the Member States' fixation on preserving a maximum amount of control over this area and restricting access to their social schemes is somewhat understandable.

At the same time, the provision of welfare services by the Member States touches in various ways on the core European aim to establish and maintain the internal market. ${ }^{593}$ More concretely, the Member States' goal to restrict access to their social security systems and safeguard their public purses tends to collide with the goal of realizing the free movement of persons within the Union and promoting social solidarity as its corollary.594 What is more, it seems to collide with the Union citizens' expressed desire to witness a realization of a more comprehensive social model at the EU level.

As confirmed by a number of recent surveys, EU citizens share high expectations with regards the Union's role in enhancing social solidarity and providing social rights beyond state borders. ${ }^{595}$ Those hopes and desires of EU citizens were not weakened by the current economic crises. ${ }^{596}$ On the

\footnotetext{
592 See the German and the Polish Lisbon Treaty case.

${ }^{593}$ Dragana Damjanovic and Bruno de Witte, 'Welfare Integration through EU Law:

The Overall Picture in the Light of the Lisbon Treaty', EUI Working Paper LAW No. 2008/34, p. 3.

594 See See Koen Lenaerts and Tinne Heremans, 'Contours of a European Social

Union in the Case-Law of the European Court of Justice' (2006) 2 EuConst 101, p.

101; Anne Pieter van der Mei, Free Movement of Persons within the European

Community: Cross-Border Access to Public Benefits (Hart Publishing, Oxford 2003), pp.

1,2 .

595 See footnote 8 above.

596 Ibid.
} 
contrary, calls for provision of stronger social guarantees and a more comprehensive approach to social issues at the EU level seemed to have increased precisely because of the crisis, thereby putting additional pressure on political and judicial actors to responsibly tackle the question of development of the European social dimension. 597

As far addressing social needs of its poorest citizens is concerned, the EU has not scored particularly well so far. Its founding documents do declare that the Union is determined to combat social exclusion and promote social justice and protection. ${ }^{598}$ Yet, no significant steps were made in direction of achieving these aims and providing EU citizens with meaningful social guarantees arising from their so-called fundamental status.

Admittedly, there was a noteworthy expansion of citizens' social rights that came as a consequence of the CJEU's generous interpretation of Treaty provisions in its groundbreaking Martínez Sala judgment. A rule was thus established whereby all economically inactive Union migrants lawfully residing in a territory of another Member State gained the right to equal treatment in access to social benefits in that state, provided that their situation falls within the material scope of EU law. ${ }^{599}$

However, positive effects of this rule for EU citizens were later significantly

\footnotetext{
${ }^{597}$ For examples of such calls by other actors, such the civil society and various transnational bodies, see: http://www.socialplatform.org/News.asp?news=31026; http://www.social-europe.eu/2013/02/labour-lawyers-urge-eu-leaders-to-respectfundamental-social-rights/; http://csc.ceceurope.org/fileadmin/filer/csc/Social_Economic_Issues/CALL/CALL_ Assemblies/2012/2012-10-09_Facing_the_crisis_Leila_Kurki.pdf; http://www.socialistsanddemocrats.eu/gpes/media3/documents/3912_EN_jobs_leafl et_en.pdf; http://www.aedh.eu/plugins/fckeditor/userfiles/file/ Communiqu\%C3\%A9s/Press\%20release\%20call\%20on\%20MEPs_08_02_10_EN.p df. Also see http://www.eesc.europa.eu/?i=portal.en.pressreleases.25172\&utm_source=EUCIS-LLL+general\&utm_campaign=e2fd9446ddEUCIS_LLL_newsletter_45_September_20129_28_2012\&utm_medium=email; http://www.assembly.coe.int/ASP/Doc/XrefViewPDF.asp?FileID=18916\&Language $=\mathrm{EN}$ and http://www.coe.int/T/DGHL/Monitoring/SocialCharter/Complaints/CC78CaseDoc 5_en.pdf.

598 See in particular Article 3(3) of the TEU, Article 151 of the TFEU and Article 34 of the Charter.

${ }^{599}$ Case C-85/96 Martínez Sala [1998] ECR I-2691, paras 62-3.
} 
circumscribed, by means of various conditions and limitations defined in secondary EU legislation and the Court's subsequent case law. On the whole, the analysis of developments in the social field of EU citizenship reveals that the overall level of social protection provided by EU law is minimal and rather unsatisfactory.

Asides from the fact that little is left of the initial progressive interpretation of Treaty provisions, the analysis also revealed a problematic trend in approaching developments in this field at the EU level. In particular, the study of relevant EU legislation and case law has shown that developments of the social aspect of EU citizenship have been so far marked by a lack of any agenda or clear guiding criteria. Instead, social rights of EU citizens have come about mainly as a product of random bargains at the legislative level and a balancing-driven case-by-case approach at the judicial level.

Given the strong tensions between opposing interests and goals present in the social policy field and the consequent controversial character of evolvement of the European social dimension, such a trend in approaching developments of citizens' social rights is not particularly surprising. Yet, as expected as it may be, it is far from unproblematic. As a result of ad hoc political bargains and a case-by-case approach driven by balancing, EU citizens' social rights developments can today be described as arbitrary, incoherent and often intransparent. What is more, these approaches and the lack of a requisite framework or guiding criteria have not only lead to incoherency and legal uncertainty, but also a lack of legitimacy in defining the scope and content of the social aspect of Union citizenship.

While the general approach towards EU law developments assumed at the national level is different in form, it is equally problematic in outcome. To be exact, the sovereignty-related approach, developed and consistently employed by highest national tribunals in their attempts to set boundaries to further developments of EU integration, including those in the social policy field, has proven to amount to an empty standard of review. Given its entirely open-ended character, this approach is capable of generating opposing normative claims, depending on the conception of sovereignty endorsed in its application. As such, it is not only ambiguous, but also highly susceptible to manipulation. While it may be a perfect tool for pushing political agendas under pretense of objectivity and legality, the sovereignty-related approach hardly provides an adequate framework or guidance for policy and lawmakers responsible for defining the social rights field. 
In this current context, marked by a lack of a comprehensive social agenda and the employment of inadequate standards in defining social rights of EU citizens, the question remains what could guide decision-making processes in this field and supply them with the needed coherency, transparency and legitimacy. Which instruments could relevant actors at both the national and the supranational level turn to in search for guidance when deciding about the scope and content of the social aspect of EU citizenship?

The argument presented here was that they do not have to look far. Instead, they should turn to one of the general principles of EU law, the principle of subsidiarity, in search for an answer to this pending question.

By shifting the focus of the analysis towards a citizen, this principle can provide policy and lawmakers with a sense of direction and a framework of legitimacy needed to comprehensibly construct the social dimension of EU citizenship. By requiring them to provide justification and engage in mutual control and dialogue, subsidiarity can ensure a more transparent and coherent decision-making process then the one we have witnessed so far. For those reasons, subsidiarity provides for a sensible way of addressing developments of EU citizens' social rights, as well as a confidence-building mechanism capable of generating support and trust in decision-making processes in this field.

Admittedly, replacing the current dominant ways of defining EU citizens' social rights with subsidiarity entails a radical change in approach. However, as seen above, there are good reasons to do so. While requiring a paradigm shift, subsidiarity is designed to ensure the protection of distinctiveness between different levels of government and the attainment of mutually envisaged goals in the social rights field. As such, it provides national and EU actors not only with guidance, but also with a way to find a common language needed to responsibly and legitimately construct the project of EU citizenship. Those truly interested in advancing citizens' interests and basic social needs should thus not fear the application of this general principle of EU law in defining social rights of EU citizens. On the contrary, they should endorse it and apply it, as it can provide this field with the needed legitimacy and help turn the citizenship of the Union into a truly fundamental status of the MS' nationals. 


\section{Bibliography}

Albi Anneli, 'Selected EU-Judgments of CEE Constitutional Courts: Lessons on How (not) to Amend the Constitutions?' (2007) 3 CYELP 39

Albi Anneli and Van Elsuwege Peter, 'The EU constitution, national constitutions and sovereignty: an assessment of a "European constitutional order"' (2004) 29(6) E.L. Rev. 741

Armstrong Kenneth A., 'United Kingdom - Divided on Sovereignty?' in Neil Walker (ed), Sovereignty in Transition (Hart Publishing, Oxford 2006)

Austin John, The Province of Jurisprudence Determined (2nd edn, Burt Franklin, New York 1970)

Aziz Miriam, 'Sovereignty Lost, Sovereignty Regained? Some Reflections on the Bundesverfassungsgericht's Bananas Judgment', EUI Working Paper RSC No. $2001 / 31$

Baquero Cruz Julio, 'The Legacy of the Maastricht-Urteil and the Pluralist Movement', EUI Working Paper RSCAS No. 2007/13

Barber Nicholas W., 'Citizenship, Nationalism and the European Union' (2002) 27 EL Rev 241

Barnard Catherine, The Substantive Law of the EU: the Four Freedoms (2nd edn, OUP, Oxford 2007)

Bell Mark, Anti-discrimination law and the European Union (OUP, Oxford 2002) 
Bellamy Richard, 'Sovereignty, Post-Sovereignty and Pre-Sovereignty: Three Models of the State, Democracy and Rights Within the EU' in Neil Walker (ed), Sovereignty in Transition (Hart Publishing, Oxford 2006)

Bermann George A., 'Taking Subsidiarity Seriously: Federalism in the European Community and the United States', (1994) 94 Colum. L. Rev. 331

Besson Samantha, 'Sovereignty in Conflict', 8(15) European Integration online Papers (2004), available at http://eiop.or.at/eiop/texte/2004-015.htm

Bieber Roland, ‘An Association of Sovereign States’ (2009) 5 EuConst 391

Biering Peter, 'The Application of EU law in Denmark: from 1986 to 2000' (2000) 37 CML Rev. 925

Bodin Jean, On Sovereignty: Four Chapters from the Six Books of the Commonwealth, edited by Julian H. Franklin (CUP, Cambridge 1992)

Bosco Alessandra 'Are national social protection systems under threat? Observations on the recent case law of the Court of Justice', (2000) 7 Notre Europe, European issues 1

Cahill Maria, 'Ireland's Constitutional Amendability and Europe's Constitutional Ambition: the Lisbon Referendum in Context' (2008) 9(10) German Law Journal 1191

Carozza Paolo G., 'Subsidiarity as a Structural Principle of International Human Rights Law', (2003) 97 American Journal of International Law 38

Chalmers Damian and others, European Union Law: Text and Materials (CUP, Cambridge 2006)

Claes Monica, 'The Europeanization of National Constitutions in the Constitutionalisation of Europe: Some Observations Against the Background of the Constitutional Experience of the EU-15' (2007) 3 CYELP 1

Claes Monica and De Visser Maartje, 'Are You Networked Yet? On Dialogues in European Judicial Networks', (2012) 8(2) Utrecht Law Review 100 
Closa Carlos, 'Citizenship of the Union and Nationality of the Member States' in David O'Keeffe \& Patrick M. Twomey (eds), Legal Issues of the Maastricht Treaty (Wiley Chancery Law, London 1994)

Conant Lisa, 'Contested Boundaries Citizens, States, and Supranational Belonging in the European Union' EUI Working Paper RSC No. 2001/27

Condinanzi Massimo, Lang Alessandra and Nascimbene Bruno, Citizenship of the Union and Freedom of Movement of Persons (Martinus Nijhoff Publishers, Leiden 2008)

Craig Paul P., 'Subsidiarity, a Political and Legal Analysis' (2012) 50 Journal of Common Market Studies 72, available at http://papers.ssrn.com/sol3/papers.cfm?abstract_id=2028332

Constantin Simona, 'Rethinking Subsidiarity and the Balance of Powers in the EU in Light of the Lisbon Treaty and Beyond' (2008) 4 CYELP 151

Crum Ben, 'What Do We Owe the Poles (or the Greeks)? Three Emerging Duties of Transnational Social Justice in the European Union' RECON Online Working Paper No. 2011/35, available at http://www.reconproject.eu/main.php/RECON_wp_1135.pdf?fileitem=545 6396

Davies Gareth, 'Subsidiarity: The Wrong Idea, in the Wrong Place at the Wrong Time'(2006) 43 Common Market Law Review 63

Davies Paul, 'Market Integration and Social Policy in the Court of Justice' (1995) 49 ILJ 49

Damjanovic Dragana, de Witte Bruno, 'Welfare Integration through EU Law: The Overall Picture in the Light of the Lisbon Treaty', EUI Working Paper LAW No. 2008/34

de Benoist Alain, 'What is Sovereignty?', translated by Julia Kostova from 'Qu'est-ce que la souveraineté?' in (1999) 96 Éléments 24, available at www.alaindebenoist.com/pdf/what_is_sovereignty.pdf

de Búrca Gráinne, 'The Principle of Subsidiarity and the Court of Justice as an Institutional Actor', (1998) 36(2) Journal of Common Market Studies 217 
de Búrca Gráinne and Craig Paul, EU Law: Text, Cases and Materials (2 ${ }^{\text {nd }}$ edn OUP, Oxford 1998)

de Búrca Gráinne and Craig Paul, EU Law: Text, Cases and Materials (4 $4^{\text {th }}$ edn OUP, Oxford 2008)

de Búrca Gráinne and Craig Paul, EU Law: Text, Cases and Materials $\left(5^{\text {th }}\right.$ edn OUP, Oxford 2011)

de la Dehesa Guillermo, 'Is It Possible To Preserve The European Social Model?', available at

www.guillermodeladehesa.com/files/quo_vadis_europe_jw_edits.doc

de Witte Bruno, 'Sovereignty and European Integration: The Weight of Legal Tradition' in Anne-Marie Slaughter, Alec Stone Sweet and J.H.H. Weiler (eds), The European Court and National Courts: Doctrine and Jurisprudence (Hart Publishing, Oxford 1998)

de Witte Bruno, 'The Closest Thing to a Constitutional Conversation in Europe: The Semi-Permanent Treaty Revision Process', in Paul Beaumont, Carole Lyons and Neil Walker (eds), Convergence and Divergence in European Public Law (Hart Publishing, Oxford 2002)

de Witte Floris, 'The End of EU Citizenship and the Means of NonDiscrimination' (2011) 18 Maastricht J. Eur. \& Comp. L. 86

Dehousse Renaud, 'Social Protection: Why the EU Needs to Deliver' (2008) 3 Les cahiers Européens, available at http://ssrn.com/abstract $=1514097$ or http://dx.doi.org/10.2139/ssrn.1514097

Delors Jacques et al., Subsidiarity: The Challenge of Change (Proceedings of the Jacques Delors Colloquium) (European Institute of Public Administration, 1991)

Dicey Albert Venn, Introduction to the Study of the Law of the Constitution (Liberty Fund, Indianapolis 1982)

d'Oliveira Hans Ulrich Jessurun, 'European Citizenship: Its Meaning, Its Potential', in Renaud Dehousse (ed), Europe after Maastricht: An Ever Closer Union? (Law Books in Europe, Munich 1994) 
Dougan Michael and Spaventa Eleanor, 'Educating Rudy and the (Non-) English Patient: A Double Bill on Residency Rights under Article 18 EC' (2003) 28(5) E.L. Rev. 699

Dougan Michael, 'The constitutional dimension to the case law on Union citizenship’ (2006) 31(5) E.L. Rev 613

Doukas Dimitrios, 'The verdict of the German Federal Constitutional Court on the Lisbon Treaty: not guilty, but don't do it again!' (2009) 34(6) E.L. Rev. 866

Endo Ken, 'The Principle of Subsidiarity: From Johannes Althusius to Jacques Delors' Hokkaido L. Rev. (1994) 44(6), 652

Endo Ken, Subsidiarity \& its Enemies: To What Extent Is Sovereignty Contested in the Mixed Commonwealth of Europe?, EUI Working Paper RSC No. 2001/24

Estella Antonio, The EU Principle of Subsidiarity and its Critique (OUP, 2002)

Everson Michelle, 'The Legacy of the Market Citizen', in Jo Shaw and Gillian More (eds), New Legal Dynamics of the European Union (Clarendon Press, Oxford 1995)

Ferrera Maurizio, 'European Integration and National Social Citizenship: Changing Boundaries, New Structuring?' (2003) 36(6) Comparative Political Studies 611

Follesdal Andreas, 'Subsidiarity' (1998) 6(2) Journal of Political Philosophy 231, available at SSRN: http://ssrn.com/abstract=1731937

Fries Sybilla and Shaw Jo, 'Citizenship of the Union: First Steps in the European Court of Justice' (1998) 4(4) Eur Pub L 544

Fouarge Didier, Poverty and Subsidiarity in Europe: Minimum Protection from an Economic Perspective (Edward Elgar, Cheltenham 2004)

Gerards Janneke, 'Fundamental Rights and Other Interests: Should it Really Make a Difference?' in Eva Brems (ed) Conflicts Between Fundamental Rights (Intersentia, Antwerp/Oxford 2008)

Gerards Janneke, 'The prism of fundamental rights' (2012) 8(2) EuConst 173 
Goldsworthy Jeffrey, The Sovereignty of Parliament: History and Philosophy (Clarendon Press, Oxford 1999)

Goldsworthy Jeffrey, Parliamentary Sovereignty: Contemporary Debates (Cambridge University Press, Cambridge 2010)

Grimm Dieter, 'Comments on the German Constitutional Court's Decision on the Lisbon Treaty: Defending Sovereign Statehood against Transforming the European Union into a State' (2009) 5 EuConst 353

Habermas Jürgen, 'Citizenship and National Identity: Some Reflections on the Future of Europe' (1992) 12(1) Praxis International 1

Habermas Jürgen, 'Why Europe Needs a Constitution' (2001) 11 New Left Review 5

Habermas Jürgen, 'The Postnational Constellation and the Future of Democracy' in The Postnational Constellation: Political Essays, ed. and trans. Max Pensky (The MIT Press, Cambridge 2001)

Habermas Jürgen, 'Constitutional democracy: a paradoxical union of contradictory principles?' (2001) 29(6) Political Theory 766

Habermas Jürgen, The Crisis of the European Union: A Response (Polity Press, Cambridge 2012)

Hailbronner Kay, 'Union Citizenship and Access to Social Benefits' (2005) 42 CML Rev 1245

Halberstam Daniel, 'The Bride of Messina: Constitutionalism and Democracy in Europe' (2005) 30 EL Rev 755

Halberstam Daniel, 'Beyond Competences: Comparative Federalism and the Duty of Cooperation' Towards a European Constitution: from the Convention the IGC and Beyond, The Federal Trust for Education and Research, Goodenough College, London, July 1-2, 2004 
Halberstam Daniel, 'Comparative Federalism and the Role of the Judiciary', (Draft forthcoming) in Keith Whittington, Daniel Kelemen, and Gregory Caldeira (eds), The Oxford Handbook of Law and Politics (OUP, 2008), available at

www.law.ed.ac.uk/europa/files/halberstamcomparative federalismjudiciary.pdf

Halberstam Daniel, 'Constitutional Heterarchy: The Centrality of Conflict in the European Union and the United States', University of Michigan Public Law and Legal Theory Working Paper No. 111/2008

Halberstam Daniel and Möllers Christoph, 'The German Constitutional Court says “Ja zu Deutschland!” (2009) 10(8) German Law Journal 1241

Harck Sten and Palmer Olsen Henrik, 'Decision concerning the Maastricht Treaty.1998 Ugeskrift for Retsvaesen, H 800' (1999) 93(1) The American Journal of International Law 209

Heise Arne and Lierse Hanna, 'Budget consolidation and the European social model: the effects of European austerity programmes on social security systems', Berlin: Friedrich-Ebert-Stiftung, Internat. Policy Analysis, 2011, available at http://library.fes.de/pdf-files/id/ipa/07891.pdf

Hobbes Thomas, Leviathan, edited by C.B. Macpherson (Penguin Books, Harmondsworth 1968)

Hoegh Katja, 'The Danish Maastricht judgment' (1999) 24(1) E.L. Rev. 80 Jacobi Hadas Alexandra, 'A Fürstin by Any Other Name? European Citizenship and the Limits of Individual Rights in the E.C.J.' (2011) 17 Colum. J. Eur. L. 643

Horsley Thomas, 'Subsidiarity and the European Court of Justice: Missing Pieces in the Subsidiarity Jigsaw?' (2012) 50(2) JCMS 267

Jackson John H., 'Sovereignty - Modern: A New Approach to an Outdated Concept', (2003) 97 Am. J. Int'l L., 782

Jacqueson Catherine, 'Union citizenship and the Court of Justice: something new under the sun? Towards social citizenship' (2002) 27 EL Rev 260 
Jakab András, 'Neutralizing the Sovereignty Question: Compromise Strategies in Constitutional Argumentation before European Integration and since' (2006) 2 EuConst, 375

Kalmo Hent and Skinner Quentin (eds), Sovereignty in Fragments: The Past, Present and Future of a Contested Concept (Cambridge University Press, Cambridge 2010)

Kemmerer Alexandra, 'The Crack in Everything: Sovereignty in a European Union of States, Peoples and Citizens', a comment on Øyvind Østerud, forthcoming in Helge Høibraaten, Jochen Hille (eds.), Northern Europe and the Future of the EU (Berliner Wissenschafts-Verlag, Berlin), available at http://papers.ssrn.com/sol3/papers.cfm?abstract_id=1334761

Keohane Robert, 'Ironies of Sovereignty: The European Union and the United States' (2002) 40 JCMS 743

Krasner Stephen D., 'Abiding Sovereignty'(2001) 22(3) International Political Science Review 229

Krehoff Bernd, 'Legitimate Political Authority and Sovereignty: Why States Cannot be the Whole Story' (2008) 14 Res Publica 283

Krisch Nico, Beyond Constitutionalism: The Pluralist Structure of Postnational Law (OUP, Oxford 2010)

Komárek Jan, 'European Constitutional Pluralism and the European Arrest Warrant: Contrapunctual Principles in Disharmony', Jean Monnet Working Paper No. 10/05, available at http://www.jeanmonnetprogram.org/papers/05/051001.html

Kumm Mattias, 'The Legitimacy of International Law: A Constitutionalist Framework of Analysis' (2004) 15(5) EJIL 907

Lenaerts Koen and Heremans Tinne, 'Contours of a European Social Union in the Case-Law of the European Court of Justice' (2006) 2 EuConst 101

Lenaerts Koen, 'European Union Citizenship, National Welfare Systems and Social Solidarity' (2011) 18(2) Jurisprudence 397 
Leibfried Stephan, 'The Social Dimension of the European Union: En Route To Positively Joint Sovereignty?' (1994) 4 Journal of European Social Policy 239

Loughlin John, 'The 'Hybrid' State: Reconfiguring Territorial Governance in Western' Europe' (2009) 10 Perspectives on European Politics and Society 51

Mac Amhlaigh Cormac and Glencross Andrew, 'Sovereignty in the EU Constitutional Order: Integrating Law and Political Science' University of Edinburgh School of Law Working Paper No. 2009/20, available at http://ssrn.com/abstract $=1471363$

MacCormick Neil, 'Beyond the Sovereign State' (1993) 56(1) MLR 1

MacCormick Neil, 'Democracy, Subsidiarity, and Citizenship in the 'European Commonwealth' (1997) 16 Law and Philosophy 331

MacCormick Neil, Questioning Sovereignty: Law, State, and Nation in the European Commonwealth (OUP, Oxford 1999)

Maduro Miguel Poiares, 'Europe's Social Self: The Sickness Unto Death' in Jo Shaw (ed), Social Law and Policy in an Evolving European Union (Hart Publishing, Oxford 2000)

Maduro Miguel Poiares, 'Striking the Elusive Balance Between Economic Freedom and Social Rights in the EU' in Philip Alston (ed), The EU and Human Rights (OUP, Oxford 2000)

Maduro Miguel Poiares, 'Sovereignty in Europe: The European Court of Justice and the Creation of a European Political Community' in Mary L. Volcansek and John F. Stack, Jr. (eds), Courts crossing borders : blurring the lines of sovereignty (Carolina Academic Press, Durham 2005)

Maduro Miguel Poiares, 'Contrapunctual Law: Europe's Constitutional Pluralism in Action' in Neil Walker (ed), Sovereignty in Transition (Hart Publishing, Oxford 2006)

Maduro Miguel Poiares, 'Where to Look for Legitimacy', available at www.ieei.pt/files/PaperMPM-IEEucp.pdf 
Martinico Giuseppe, 'Dating Cinderella: On Subsidiarity as a Political Safeguard of Federalism in the European Union', (2011) 17(4) European Public Law 649

Mayer Franz C., 'Rashomon in Karlsruhe - A reflection on Democracy and Identity in the European Union', (2011) 9 (3-4) International Journal of Constitutional Law 757

McGrew Anthony, 'Transnational Democracy: Theories and Prospects', in April Carter and Geoffrey Stokes (eds.) Democratic Theory Today: Challenges for the 21 Century (Polity Press, Cambridge 2002), available at http://www.polity.co.uk/global/transnational-democracy-theories-andprospects.asp.

Millon-Delsol Chantal, L'état subsidiaire: Ingérence et non-ingérence de l'Etat: le principe de subsidiarité aux fondements de l'histoire européenne (Presses Universitaires de France, Paris 1992)

Millon-Delsol Chantal, Le Principe de Subsidiarité (Presses Universitaires de France, Paris 1993)

More Gillian, 'The Principle of Equal Treatment: From Market Unifier to Fundamental Right?' in Paul Craig and Gráinne de Búrca (eds), The Evolution of EU Law (OUP, Oxford 1999)

Mouthaan Solange, 'France: amending the amended Constitution' (1998) 23(6) E.L. Rev. 592

Murkens Jo Eric Khushal, 'Bundesverfassungsgericht (2 BvE 2/08): "We want our identity back" - the revival of national sovereignty in the German Federal Constitutional Court's decision on the Lisbon Treaty' (2010) Public law 530

Obermaier Andreas J., 'Fine-tuning the Jurisprudence: The ECJ's Judicial Activism and Self-restraint' Institute for European Integration Research Working Paper No. 02/2008, p. 33

O'Leary Síofra, The Evolving Concept of Community Citizenship: From the Free Movement of Persons to Union Citizenship (Kluwer, The Hague 1996) 
O'Leary Síofra, 'Equal treatment and EU citizens: A new chapter on crossborder educational mobility and access to student financial assistance' (2009) 34(4) E.L. Rev. 612

O'Keeffe David, 'Union Citizenship' in David O'Keeffe \& Patrick M.

Twomey (eds), Legal Issues of the Maastricht Treaty, (Wiley Chancery Law, London 1994)

O'Neill Paul and Sandler Susan R., 'The EU Citizenship Acquis and the Court of Justice: Citizenship Vigilante or Merely Vigilant Treaty Guardian?' (2008) 7(3) Richmond Journal of Global Law and Business 206

Preuß Ulrich K., 'Problems of a Concept of European Citizenship' (1995) 1(3) ELJ 267

Reich Norbert, 'Union Citizenship: Metaphor or Source of Rights?' (2001) 7(1) ELJ 4

Ritzer Christoph, Ruttloff Marc and Linhart Karin, 'How to Sharpen a Dull Sword - The Principle of Subsidiarity and its Control' (2006) 7(9) German Law Journal 733

Rousseau Jean-Jacques, The Social Contract and Other Later Political Writings, edited by Victor Gourevitch (CUP, Cambridge 1997)

Sadurski Wojciech, 'Constitutionalization of the EU and the Sovereignty Concerns of the New Accession States: The Role of the Charter of Rights', EUI Working Paper LAW No. 2003/11

Sadurski Wojciech, "Solange, chapter 3': Constitutional Courts in Central Europe-Democracy—European Union’ (2008) 14(1) ELJ 1

Sarooshi Dan, International Organizations and Their Exercise of Sovereign Powers (Oxford Monographs in International Law Series) (OUP 2005)

Scharpf Fritz W., 'The European Social Model - Coping with the Challenges of Diversity' (2002) 40(4) JCMS 645 
Shaw Jo, 'Twin-Track Social Europe: The Inside Track', in David O'Keeffe \& Patrick M. Twomey (eds), Legal Issues of the Maastricht Treaty (Wiley Chancery Law, London 1994)

Shaw Jo, 'The Interpretation of European Union Citizenship' (1998) 61(3) MLR 293

Shaw Jo, 'Citizenship of the Union: Towards Post-National Membership?', in the European University Institute (ed), Collected Courses of the Academy of European Law 1995, Vol. VI, Book 1 (Kluwer, The Hague 1998)

Shaw Jo, Law of the European Union, (3 ${ }^{\text {rd }}$ edn, Palgrave Macmillan Law Masters 2000)

Shaw Jo, 'A Strong Europe is a Social Europe', The Federal Trust Constitutional Online Paper Series No. 05/03

Shaw Jo, 'Citizenship: Contrasting Dynamics at the Interface of Integration and Constitutionalism', EUI Working Paper RSCAS No. 2010/60

Shaw Jo, 'EU citizenship and the edges of Europe', CITSEE Working Paper No. 2012/19, available at http://www.law.ed.ac.uk/citsee/workingpapers/

Slaughter Anne-Marie, 'Judicial Globalization' (1999-2000) 40 Va.J.Int'l L. 1103

Stone Sweet Alec, Slaughter Anne-Marie, Weiler Joseph H. H. (eds.), The European Court and National Courts, Doctrine and Jurisprudence: Legal Change in Its Social Context (Hart Publishing, Oxford 1998)

Suanzes Joaquin Varela, 'Sovereignty in British Legal Doctrine' (1999) 6(3) MurUEJL

Van der Mei Anne Pieter, Free Movement of Persons within the European Community: Cross-Border Access to Public Benefits, (Hart Publishing, Oxford 2003)

Van der Mei Anne Pieter, 'Union Citizenship and the Legality of Durational Residence Requirements for Entitlement to Student Financial Aid' (2009) 16 Maastricht J. Eur. \& Comp. L. 494 
Vinx Lars, 'The incoherence of strong popular sovereignty', (2013) 11(1) International Journal of Constitutional Law, 101

Walker Neil, 'The Idea of Constitutional Pluralism', EUI Working Paper LAW No. 2002/1

Walker Neil, 'Late Sovereignty in the European Union' in Neil Walker (ed), Sovereignty in Transition (Hart Publishing, Oxford 2006)

Weatherill Stephen, 'Competence and Complexity, Simplification and Clarification... and Legitimacy too' in Stephen Weatherill and Kalypso Nicolaidis (eds), Whose Europe? National Models and the Constitution of the European Union, Papers of a Multi-Disciplinary Conference held in Oxford in April 2003, available at http://www.europaeum.org/files/publications/reports/WhoseEurope.pdf

Weiler Joseph H.H., 'To be a European Citizen', in Scritti in onore di Giuseppe Federico Mancini, Vol. II - Diritto dell'Unione Europea (Giuffrè, Milano 1998)

Weiler Joseph H.H., The Constitution of Europe: "Do the New Clothes Have an Emperor?" and Other Essays on European Integration (CUP, Cambridge 1999)

Weiler Joseph H.H., 'Federalism and Constitutionalism: Europe's Sonderweg' Harvard Jean Monnet Working Paper No. 10/00 (2001)

White Robin C.A., 'Free Movement, Equal Treatment, and Citizenship of the Union' (2005) 54 ICLQ 885

White Robin C.A., 'Citizenship of the Union, Governance, and Equality' (2006) 29 Fordham Int'l L.J. 790

Wyatt Derrick and others, Wyatt and Dashwood's European Union Law (5 $5^{\text {th }}$ edn Sweet and Maxwell, London 2006) 


\section{Summary}

The urgency to redefine the European Union project in view of the current crisis brings to the forefront the question about the future of the social aspect of European integration. 'Socializing Europe Solidifying EU citizenship' addresses this question by focusing on the evolution of the social dimension of the concept of EU citizenship. Since the introduction of this concept twenty years ago, its social aspect is the part that has been most dramatically developed. This book analyzes the hitherto evolution of social rights of EU citizens and addresses the prospect of their future development.

The book starts by finding that this field of European integration has been so far dominated by strong conflicts of interests and goals. On the one hand, there are the interests and goals of preserving the Member States' regulatory autonomy, public purses and social security systems. On the other hand, there are the interests and goals of promoting the freedom of movement in the internal market, strengthening the protection of social rights of Union citizens' and expanding solidarity at the EU level.

To this day, the tensions between these European and national interests and goals have not been addressed in a comprehensive manner. There has been a lack of an elaborate legal and political agenda for development of the European social dimension. Yet, despite the absence of such a comprehensive plan, there have been several important trends in approaching and, ultimately, shaping this aspect of European integration at the European and national level. The book identifies and subsequently evaluates these trends. 
At the EU level, the dominant approach in addressing the development of Union citizens' social rights has thus far consisted in random political bargains and a case-by-case approach driven by balancing. This is illustrated through a detailed analysis of the current EU legislation and case law in the social field of EU citizenship. The analysis shows that the concept of EU citizenship has been gradually expanded so as to guarantee protection of certain social rights to European citizens. This is mainly due to the generous interpretation of the Treaty provisions on Union citizenship by the European Court of Justice. As a result of this interpretation, the right to equal treatment in access to social benefits is now provided to all economically inactive Union migrants lawfully residing in a territory of another Member State, as long as their situation falls within the material Treaty scope. However, EU law did not leave the Member States completely powerless in defending their social security systems and public purses. On the contrary, it provided them with a number of defense mechanisms, which limit access of EU citizens to social benefits and function as economic safeguards, protecting the national public finances from unreasonable burdens.

The analysis of the relevant case law and legislation leads to the conclusion that this 'give and take' approach has virtually stripped EU citizens' social rights of all the positive effects arising from the cocalled fundamental status of Union citizenship. What is more, it has led to a lack of coherency, legal certainty and legitimacy in developing the social dimension of EU citizenship. Therefore, the current approach at the EU level is deemed inadequate for developing this important aspect of European integration.

At the national level, the trend in approaching EU law developments, including those in the social policy field, is rather different. It consists of the frequent conditioning of EU law developments upon the preservation of the state sovereignty. This trend and the deriving 'sovereignty-related' approach have been present throughout the history of European integration. It is the most visible and best elaborated in national constitutional case law dealing with the review of Treaty amendments. 
Following a comprehensive analysis of these judgments, it is concluded that the reasoning applied by national highest courts and their followers essentially amounts to the following: So long as changes in EU law do not threaten the state's core sovereign powers, such changes are regarded as compatible with Member States' fundamental constitutional principles and, therefore, as acceptable. According to this approach, it follows that any future developments of EU law will be regarded as permissible so long as they do not represent a serious and existential threat to state sovereignty.

In order to evaluate its exact repercussions and adequacy, this national approach towards EU law developments is employed in the specific field of social rights of EU citizens. This book reveals that the seemingly clear 'sovereignty-related' reasoning in reality amounts to an empty standard of assessment. This is mainly due to the ambivalent character of the notion of sovereignty upon which the approach rests. As such, this approach is capable of generating opposing normative claims, which is demonstrated by relying on different conceptions of sovereignty in its application. It is thus concluded that the 'sovereigntyrelated' approach fails to provide any meaningful guidance for policy and lawmakers in the social policy field. This, in turn, makes it an inadequate standard for addressing the future of the social dimension of EU citizenship.

Given the perceived lack of an elaborated agenda for addressing developments in this field and the inadequacy of the currently assumed approaches, the question is posed what could than guide the evolution of citizens' social rights as European integration proceeds. How could this significant aspect of the European project be supplied with the needed coherency, transparency and legitimacy?

In the attempt to resolve this dilemma, a search is conducted of alternative ways of constructing the social aspect of European integration. As a result of this search, it is suggested that those concerned with the future of the social rights of EU citizens do not have to look far for the needed inspiration and suitable guidance. Rather, they should turn to one of the fundamental principles of EU law - the principle of subsidiarity. 
For subsidiarity to truly provide adequate guidance, however, it is argued that due regard needs to be paid to both its positive and negative side. The positive side of subsidiarity relates to the possibility of intervention of a higher entity vis-à-vis a lower entity. The negative side refers to the limits of such intervention. So far, in the context of European integration, the emphasis has been put only on the negative side of the principle of subsidiarity. Meanwhile, its positive side, which provides for a 'social efficiency criterion', has been rather neglected.

This book suggests that putting equal weight on these two inherently tied aspects of subsidiarity is not only necessary in order to ensure full respect of this fundamental principle of EU law. It is also useful as a guide for policy and lawmaking in the social rights' field of EU citizenship.

It is argued that by shifting the focus of the analysis towards the citizen, the principle of subsidiarity can provide national and European decision-makers with a sense of direction and a framework of legitimacy needed to comprehensibly construct the social dimension of EU citizenship. At the same time, by requiring them to provide justification and engage in mutual control and dialogue, subsidiarity can ensure a more transparent and coherent decision-making process then the one witnessed so far. For these reasons, subsidiarity is recommended as the sensible way of addressing EU citizens' social rights developments, as well as a confidence-building mechanism capable of generating trust in decision-making processes in this field.

This book acknowledges that adopting this kind of approach requires a major paradigm shift. Yet, it is concluded that there are good reasons to do so. Subsidiarity is designed to ensure the protection of distinctiveness between different levels of government and the attainment of mutually envisaged goals in the social rights field. As such, subsidiarity can provide national and EU actors not only with the needed direction, but also help them find a common language. This is essential in order to responsibly and legitimately construct the project of European Union citizenship and its social dimension. 


\section{Samenvatting}

De dringende noodzaak, gezien de huidige crisis, om het Europese Unie project een nieuwe invulling te geven, roept de vraag op over de toekomst van het sociale aspect van Europese integratie. 'Socializing Europe - Solidifying EU citizenship' behandelt deze vraag door te concentreren op de ontwikkeling van de sociale dimensie van het begrip 'EU-burgerschap'. Sinds de invoering van dit begrip twintig jaar geleden heeft het sociale aspect de meest vergaande ontwikkeling doorgemaakt. In dit boek wordt een analyse gemaakt van de evolutie van de sociale rechten van EU-burgers tot op heden en wordt hun verdere ontwikkelingsperspectief besproken.

De eerste bevinding in dit boek is dat dit onderdeel van Europese integratie tot nu toe werd beheerst door ernstige belangenverstrengeling en doelstellingen. Enerzijds is er het belang bij en het streven naar behoud van de wetgevingsautonomie, overheidsmiddelen en sociale verzekeringsstelsels van de lidstaten. Anderzijds spelen het belang van en het streven naar het bevorderen van vrij verkeer binnen de interne markt, het versterken van de sociale rechten van EU-burgers en het vergroten van de solidariteit op Europees niveau een rol.

De spanningen tussen deze Europese en nationale belangen en doelstellingen zijn tot nu toe niet grondig aangepakt. Het heeft ontbroken aan een uitgebreide juridische en politieke agenda voor de ontwikkeling van een Europese sociale dimensie. Ondanks het ontbreken van een dergelijk uitgebreid plan, zijn er op Europees en nationaal niveau niettemin verscheidene belangrijke tendensen waar te nemen in benadering en uiteindelijke vormgeving van dit aspect van Europese integratie. In dit boek worden deze tendensen eerst vastgesteld, waarna ze worden beoordeeld. 
De belangrijkste benadering van hoe moet worden ingespeeld op de ontwikkeling van de sociale rechten van EU-burgers heeft tot nu toe bestaan uit willekeurige politieke afspraken en een casuïstische benadering uit het oogpunt van het vinden van evenwicht. Dit wordt duidelijk gemaakt aan de hand van een gedetailleerde analyse van de huidige EU wetgeving en jurisprudentie met betrekking tot het sociale aspect van het EU-burgerschap. De analyse laat zien dat het begrip 'EU-burgerschap' geleidelijk aan is opgerekt tot het garanderen aan EU-burgers van bescherming van bepaalde sociale rechten. Dit is voornamelijk het gevolg van een ruime interpretatie van de Verdragsbepalingen met betrekking tot EU-burgerschap door het Hof van Justitie van de Europese Unie. Dit heeft tot gevolg gehad dat het recht op gelijke behandeling met betrekking tot toegang tot sociale uitkeringen thans ook van toepassing is op alle, economisch inactieve interne migranten die rechtmatig verblijven op het grondgebied van een andere lidstaat, mits hun situatie valt binnen het materiële toepassingsgebied van het Verdrag. EU-recht heeft de lidstaten echter niet helemaal met lege handen laten staan waar het de verdediging van hun sociale verzekeringsstelsels en openbare middelen betreft. Integendeel, het heeft hun een aantal verdedigingsmiddelen aangereikt, die de toegang van EU-burgers tot sociale uitkeringen beperken en als economische waarborgen functioneren, waardoor de nationale overheidsfinanciën worden beschermd tegen onredelijke lasten.

De conclusie die uit de analyse van relevante jurisprudentie en wetgeving kan worden getrokken, is dat deze 'geven en nemen' benadering de sociale rechten van de EU-burgers praktisch heeft ontdaan van alle positieve effecten die voortvloeien uit de zogenoemde 'primaire hoedanigheid' van EU-burgerschap. Sterker nog, het heeft geleid tot een gebrek aan coherentie, rechtszekerheid en legitimiteit bij het ontwikkelen van de sociale dimensie van het EU-burgerschap. De huidige benadering op Europees niveau wordt daarom niet geschikt bevonden voor het ontwikkelen van dit belangrijke aspect van Europese integratie.

Op nationaal niveau zien we een heel andere tendens in de benadering van ontwikkelingen in het EU-recht, ook van die op het gebied van sociaal beleid. Deze tendens bestaat uit het veelvuldig voorwaardelijk 
stellen van behoud van de staatssoevereiniteit. Deze tendens en de daarvan afgeleide 'soevereiniteit-gerelateerde' benadering zien we door de hele geschiedenis van de Europese integratie heen. Het duidelijkst en meest uitgewerkt vinden we deze benadering in nationale jurisprudentie inzake constitutionele toetsing van Verdragswijzigingen.

Aan de hand van een uitgebreide analyse van deze uitspraken kan worden vastgesteld dat de argumentatie die door de nationale hoogste rechters en hun navolgers wordt toegepast in beginsel terug te brengen is tot het volgende: zo lang wijzigingen in Europese regelgeving de soevereine bevoegdheden van de staat niet in gevaar brengen, worden deze beschouwd als verenigbaar met de fundamentele staatsrechtelijke beginselen van de lidstaten en om die reden als aanvaardbaar. Uit deze benadering volgt dat alle toekomstige ontwikkeling van het EU-recht kunnen worden beschouwd als toelaatbaar, mits ze geen ernstige en reële bedreiging vormen voor de staatssoevereiniteit.

Om de precieze nadelige gevolgen en de geschiktheid van deze nationale benadering van ontwikkelingen in EU-recht te beoordelen, wordt ze toegepast op het gebied van de sociale rechten van EUburgers. Dit boek laat zien dat de ogenschijnlijk heldere 'soevereiniteitsargumentatie' in wezen niet meer is dan een loze beoordelingsnorm. Dit komt voornamelijk door de ambivalentie die besloten ligt in het begrip 'soevereiniteit' waarop de benadering stoelt. Daardoor kan deze benadering tegengestelde normatieve aanspraken genereren, wat tot uiting komt in de uiteenlopende opvattingen van soevereiniteit die worden gehanteerd bij de toepassing ervan. Vastgesteld wordt dat de aan soevereiniteit gekoppelde benadering geen zinnig richtsnoer kan vormen voor beleidsmakers en wetgevers op het gebied van sociaal beleid, waardoor het een ondeugdelijke norm is voor het werken aan de toekomst van de sociale dimensie van het EU-burgerschap.

Gezien het gevoelde gemis van een uitgebreide agenda ten behoeve van het inspelen op ontwikkelingen op dit gebied en de ondeugdelijkheid van de benaderingen waarmee op het ogenblik wordt gewerkt, wordt de vraag gesteld wat voor richtsnoer de geleidelijke ontwikkeling van de sociale rechten van EU-burgers kan ondersteunen bij de voortgang 
van het Europese integratieproces. Hoe kan dit belangrijke aspect van het Europese Unie project worden voorzien van de benodigde coherentie, transparantie en legitimiteit?

In een poging een uitweg uit dit dilemma te vinden, wordt een zoektocht ondernomen naar alternatieven ten behoeve van de opbouw van het sociale aspect van Europese integratie. Deze zoektocht levert het idee op dat degenen die begaan zijn met de toekomst van de sociale rechten van EU-burgers niet ver hoeven te zoeken voor de benodigde inspiratie en een geschikt richtsnoer. Ze kunnen hun blik gewoon richten op een van de fundamentele beginselen van EU-recht - het subsidiariteitsbeginsel.

Wil men echter dat subsidiariteit werkelijk als een deugdelijk richtsnoer functioneert, dan, zo wordt gesteld, moet er serieuze aandacht worden besteed aan zowel de positieve als de negatieve kant van subsidiariteit. De positieve kant ziet op de mogelijkheid van interventie door een hoger lichaam ten opzichte van een lager lichaam. De negatieve kant betreft de grenzen aan een dergelijke interventie. Tot nu toe is in het kader van Europese integratie de nadruk uitsluitend gelegd op de negatieve kant van subsidiariteit, terwijl de positieve kant ervan, de kant die een 'sociaal effect' criterium biedt, nogal is verwaarloosd.

In dit boek wordt voorgesteld dat toekenning van evenveel gewicht aan deze twee innig verbonden aspecten van subsidiariteit niet alleen noodzakelijk is om volledige eerbiediging van dit fundamentele beginsel van EU-recht te verzekeren, maar dat het tevens gebruikt kan worden als richtsnoer voor beleid en wetgeving op het onderdeel sociale rechten van EU-burgerschap.

Er wordt gesteld dat door het verleggen van de kern van de analyse naar de burger, het subsidiariteitsbeginsel richtinggevend kan zijn voor nationale en Europese besluitvormers en hun een legitimiteitskader kan bieden. Dat is nodig voor een degelijk uitbouw van de sociale dimensie van EU burgerschap. Tegelijkertijd kan subsidiariteit een meer transparant en coherent beleidsvormingsproces creëren dan tot nu toe het geval was door van deze besluitvormers te eisen dat zij zich rechtvaardigen, elkaar controleren en een dialoog met elkaar aangaan. 
Om deze redenen wordt subsidiariteit aanbevolen als enerzijds een verstandige manier van omgaan met ontwikkelingen op het terrein van de sociale rechten van EU-burgers en anderzijds een instrument waarmee vertrouwen in het besluitvormingsproces op dit gebied kan worden gekweekt.

In dit boek wordt erkend dat het kiezen voor een dergelijke benadering een behoorlijke paradigmawisseling vergt. Niettemin wordt geconcludeerd dat daarvoor goede redenen zijn. Subsidiariteit is zo vormgegeven dat het het behoud verzekert van het scherpe onderscheid tussen enerzijds de verschillende bestuurslagen en anderzijds het bereiken van wederzijds beoogde doelen op het gebied van sociale rechten. In die zin kan subsidiariteit niet alleen de benodigde richting bieden aan nationale en Europese actoren, maar kan het beginsel ook hulp bieden bij het vinden van een gezamenlijke taal. Dit is essentieel voor een verantwoord en gelegitimeerd bouwen aan het EU-burgerschapsproject en zijn sociale dimensie.

Translated by Louise Rayar, B.tr 



\title{
CURRICULUM VITAE
}

\author{
TINA ORŠOLIĆ DALESSIO
}

PERSONAL INFORMATION

Born: August 29, 1983; Zagreb, Croatia

Nationality: Croatian, French

Languages: Croatian, English, French

Address: Medvedgradska 58, 10000 Zagreb, Croatia

Phone: +385 959082702

E-mail: tinaorsolic@gmail.com

EDUCATION

2010 - present

Doctoral researcher in European Law at Maastricht University.

2011

Visiting student at the European

University Institute.

2009

Doctoral researcher in European Law at Tilburg University.

2008

LL.M., the University of Michigan Law School.

2006

LL.B., magna cum laude, the University of Zagreb, Faculty of Law. 
Teaching:

2007 - present

Teaching Assistant at the Department of General Theory of Law and State, University of Zagreb, Faculty of Law.

2009

Lecturer at J. J. Strossmayer University in Osijek, Faculty of Law, Master in European Studies Programme (MEUS).

$2008-2009$

Lecturer at the Postgraduate Specialist Studies in Conference Interpreting, University of Zagreb.

Internship: 2008

2008 Stagiaire in the Cabinet of Advocate General M.P. Maduro, at the Court of Justice of the European Union.

AWARDS

2007

Certificate of Merit Award by the University of Michigan Law School for outstanding performance in Jurisprudence. 
Chancellor's Award, University of Zagreb, for placing at the European Law Moot Court Competition.

2002

Dean of the University of Zagreb, Faculty of Law Award for Exceptional Success in Studies.

$2010-2012$

$2007-2008$

2006

$2003-2005$

$2002-2004$
Huygens Scholarship from the Dutch Ministry of Education, Culture and Science.

Michigan Grotius Fellowship from the University of Michigan Law School.

Scholarship from the Croatian Ministry of Science, Education and Sports.

Scholarship from the City of Zagreb, Croatia.

Scholarship from Zlatko Crnić Foundation. 